



\section{REVISTA PERUANA $\mathcal{D E}$}

\section{DERECHO IN IIERN NACIONAL}

ÓRGANO DE DIFUSIÓN DE LA SOCIEDAD PERUANA DE DERECHO INTERNACIONAL

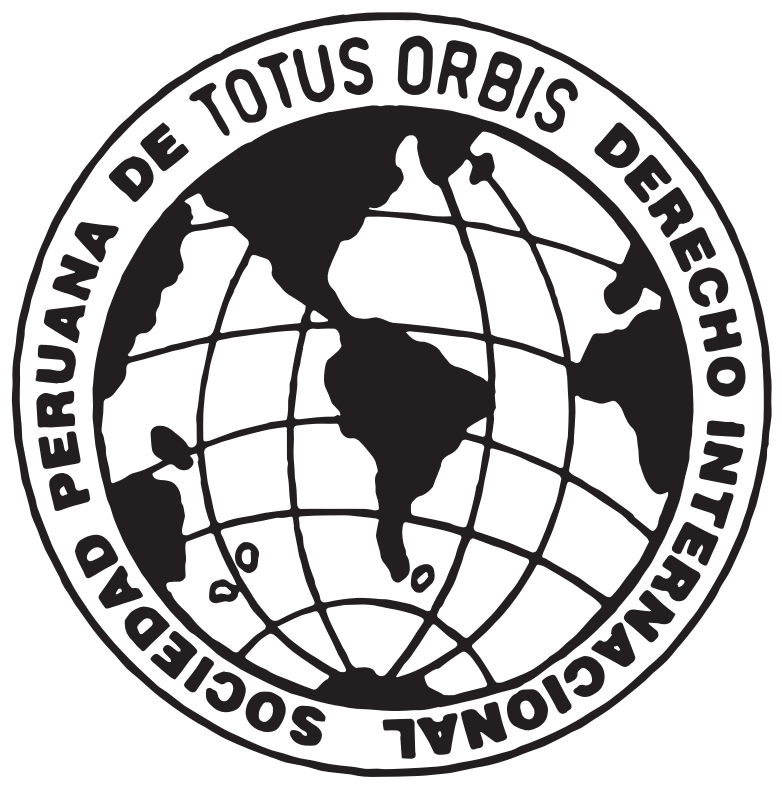

TOMO LXX ENERO - ABRIL 2020 N 164 LIMA - PERÚ 
REVISTA PERUANA DE DERECHO INTERNACIONAL

TOMO LXX ENERO - ABRIL $2020 \mathrm{~N}^{\circ} 164$

HECHO EL DEPÓSITO LEGAL EN LA BIBLIOTECA NACIONAL DEL PERÚ: $N^{\circ}$ 99-1510

Las opiniones recogidas en las colaboraciones publicadas en la Revista son de exclusiva responsabilidad de sus autores.

Sociedad Peruana de Derecho Internacional Jr. A. Miró Quesada $\mathrm{N}^{\circ}$ 247, Oficina $\mathrm{N}^{\circ}$ 508, Edificio "Rimac International”, Lima 1 - Perú

Teléfonos: 204-3532; 204-3531; 204-3530

Revista en versión electrónica: spdiojs.org/ojs/index.php/RPDI/index

Página Web: www.spdi.org.pe

E-mail: spdi@spdi.org.pe

Blog Institucional: https://sociedadperuanadederechointernacional.blogspot.com/

Facebook: Sociedad Peruana de Derecho Internacional

https://twitter.com/SPDInternaciona

https://www.instagram.com/spderechointernacional/?hl=es-la

Patrimonio Cultural de la Nación: Reconocimiento mediante Resolución Viceministerial N 233-2019-VMPCIC-MC del 12 de diciembre de 2019.

Se terminó de imprimir en abril del 2020 por

Tarea Asociación Gráfica Educativa

Pasaje María Auxiliadora 156, Breña

Lima - Perú

Tiraje: 1,000 ejemplares

Reservado todos los derechos de reproducción total o parcial 


\section{Totus orbis qui aliquio modo est una res publica}

Todo el mundo, de una manera u otra, es una cosa pública. Francisco de Vitoria 



\section{SOCIEDAD PERUANA $\mathcal{D E}$}

\section{DERECHO IN IERANACIONAL}

CONSEJO DIRECTIVO

\section{Presidente \\ Oscar Maúrtua de Romaña}

Vice Presidente

Hernán Couturier Mariátegui

\section{Secretario}

Miguel Angel Rodríguez Mackay
Tesorero

Alexander Antialón Conde

Vocales

Juan Álvarez Vita

Alejandro Deustua Caravedo

Gonzalo García Calderón Moreyra

Augusto Hernández Campos

José Luis Pérez Sánchez-Cerro

Oscar Schiappa-Pietra Cubas

\section{CONSEJO DE HONOR}

De Trazegnies Granda, Fernando

Ferrero Costa, Eduardo

García Belaunde, José Antonio

García-Sayán Larrabure, Diego

Gutiérrez Reinel, Gonzalo

Luna Mendoza, Ricardo
Mac Lean Ugarteche, Roberto

Maúrtua de Romaña, Oscar

Rodríguez Cuadros, Manuel

Tudela van Breugel Douglas, Francisco

Wagner Tizón, Allan

\section{CONSEJO EDITORIAL DE LA REVISTA*}

Maúrtua de Romaña, Oscar (Director)

Pérez Sánchez-Cerro, José Luis

(Coordinador)

Antialón Conde, Alexander (Editor)

*En concordancia con la versión electrónica de la revista y conforme al proceso de indexación.
Deustua Caravedo, Alejandro

Schiappa-Pietra Cubas, Oscar

Hernández Campos, Augusto

\section{MIEMBROS EMÉRITOS}

Aramburú Menchaca, Andrés

Arias-Schreiber Pezet, Alfonso

Bákula Patiño, Juan Miguel

Belaunde, Víctor Andrés

Bustamante y Rivero, José Luis

Deustua Arróspide, Alejandro

Ferrero Rebagliati, Raúl 
MIEMBROS TITULARES

\begin{tabular}{|ll|}
\hline Alvarez Vita, Juan & Luna Mendoza, Ricardo \\
Alzamora Traverso, Carlos & Mac Lean Ugarteche, Roberto \\
Antialón Conde, Alexander & Maúrtua de Romaña, Oscar \\
Belaunde Moreyra, Martín & Novak Talavera, Fabián \\
Belevan-McBride, Harry & Palma Valderrama, Hugo \\
Couturier Mariátegui, Hernán & Pérez de Cuéllar, Javier (§) \\
De Soto Polar, Alvaro & Pérez Sánchez-Cerro, José Luis \\
De Trazegnies Granda, Fernando & Revoredo de Mur, Delia \\
Deustua Caravedo, Alejandro & Rodríguez Cuadros, Manuel \\
Ferrero Costa, Eduardo & Rodríguez Mackay, Miguel Ángel \\
Ferrero Costa, Raúl & Roncagliolo Higueras, Nicolás \\
García Belaunde, Domingo & Schiappa-Pietra Cubas, Oscar \\
García Belaunde, José Antonio & Sosa Voysest, Claudio \\
García Calderón Moreyra, Gonzalo & Tudela van Breugel Douglas, Francisco \\
García-Corrochano Moyano, Luis & Valdez Carrillo, Jorge (§) \\
García-Sayán Larrabure, Diego & Vera Esquivel, Germán \\
Guillén Salas, Fernando & Villarán Koechlin, Roberto \\
Gutiérrez Reinel, Gonzalo & Wagner Tizón, Allan \\
Hernández Campos, Augusto & \\
\hline
\end{tabular}

\section{MIEMBROS ASOCIADOS}

\begin{tabular}{|c|c|}
\hline Agüero Colunga, Marisol (*) & Malapi Hernández, Daniela (*) \\
\hline Alcalde Cardoza, Javier & Meier Espinosa, José A. (*) \\
\hline Astete Rodríguez, Elizabeth (*) & Miró Quesada Rada, Francisco \\
\hline Brousset Barrios, Jorge & Namihas Pacheco, Sandra (*) \\
\hline Chuquihuara Chil, Luis & Pinto-Bazurco Barandiarán, Jose F. \\
\hline Colunge Villacorta, Jorge $(*)$ & Pinto-Bazurco Rittler, Ernesto \\
\hline Cumpa García-Naranjo, Luciana (*) & Rodríguez Brignardello, Hugo \\
\hline D’Alessio Ipinza, Fernando (*) & Ruda Santolaria, Juan José (*) \\
\hline Dañino Zapata, Roberto & Saavedra Calderón, José Antonio \\
\hline De Althaus Guarderas, Miguel & Salmón Gárate, Elizabeth \\
\hline Echeverría Herrera de De Pury, María E. & Sandoval Aguirre, Oswaldo (*) \\
\hline Fairlie Reinoso, Alan (*) & Sierralta Ríos, Anibal \\
\hline Ibañez Carranza, Luz (*) & Umeres Alvarez, Juan Humberto (*) \\
\hline Kisic Wagner, Drago & Velásquez Rivas-Plata, Elvira \\
\hline Lázaro Geldres, Jorge & Velit Granda, Juan \\
\hline Lévano Torres, Oscar & Vigil Toledo, Ricardo (*) \\
\hline Loayza Tamayo, Carolina & Yepes del Castillo, Ernesto \\
\hline Lozada Tamayo, Samuel & Yrigoyen Yrigoyen, Martín \\
\hline
\end{tabular}

(*) PARA INCORPORACIÓN FORMAL 


\section{MIEMBROS CORRESPONDIENTES}

$\begin{array}{ll}\text { Buergenthal, Thomas (Estados Unidos) } & \text { Llanos Mansilla, Hugo (Chile) } \\ \text { Cho, Key Sung (Corea) } & \text { Noboa Bejarano, Gustavo (Ecuador) } \\ \text { Furnish, Dale Beck (Estados Unidos) } & \text { Suphamongkhon, Kantathi (Tailandia) } \\ \text { Ikeda, Daisaku (Japón) } & \text { Wolff, Francis (Francia) }\end{array}$

COORDINADOR GENERAL

Alexander Antialón Conde 



\section{SUMARIO \\ No 164 (ENERO-ABRIL 2020)}

\section{Artículos}

Pág.

- El rol de las líneas de base en el derecho del mar y el proceso de delimitación marítima entre el Perú y Chile Oscar Maúrtua de Romaña

- La justicia social y el derecho internacional José Luis Pérez Sánchez-Cerro

- Convenio sobre Arreglo de Diferencias Relativas a Inversiones entre Estados y nacionales de otros Estados (CIADI)

Gonzalo García Calderón

- El asilo diplomático y el caso Alan García Augusto Hernández Campos

- La solidaridad americana en tiempos del COVID-19: el bloqueo a Cuba Alexander Antialón Conde

- Principios de derecho internacional de los derechos humanos aplicables en estado de emergencia COVID-19 y el uso de la fuerza por parte del personal policial Carolina Loayza-Tamayo 
- El debate sobre el carácter jurídico del derecho de gentes en Hispanoamérica durante el siglo XIX:

La contraposición entre José Silva Santisteban y Andrés Bello

Pablo Rosales Zamora

- Análisis crítico del concepto de apátrida de facto Juan Fuentes \& David Sánchez

- La regulación jurídica de las relaciones patrimoniales de las parejas internacionales en la UE Ubaldo Greco

\section{InTERVEnCIONES EN ACtos ACAdÉMicos}

- Cien años de multilateralismo y retos para el segundo centenario

Oscar Schiappa-Pietra Cubas

\section{HOMENAJES}

- Igor Velázquez Rodríguez: su legado perpetuo y ejemplar para el Perú

Oscar Maúrtua de Romaña

- Homenaje al Embajador Javier Pérez de Cuéllar. Cien años al servicio del Perú y de la justicia Juan Álvarez Vita 


\section{Notas NECROLÓgICAS}

- Javier Pérez de Cuéllar: El Perú y Latinoamérica han perdido a un diplomático excepcional y el mundo a un internacionalista que luchó por la paz y la dignidad global

Oscar Maúrtua de Romaña

- Javier Pérez de Cuéllar: Una vida dedicada al Perú y a la Diplomacia

Manuel Rodríguez Cuadros

- Jorge Valdez Carrillo

Gustavo Meza-Cuadra

- José Agustín de la Puente: El Perú como ilusión Francisco Bobadilla Rodríguez

\section{Pronunciamiento}

- Pronunciamiento del Consejo Directivo respecto a la Ley N 31012 "Ley de protección policial"

\section{RESEÑas BibLIOGRÁFICAS}

- Integridad en las Políticas Públicas: Claves para prevenir la corrupción, de Corporación Andina de Fomento Luciana Cumpa García-Naranjo 
- Tratado de Derecho Constitucional, de Raúl Chanamé Orbe Pablo Rosales Zamora

- Tiempos de transición. La conformación de un nuevo orden internacional, de Fabián Novak y Sandra Namihas Silvio Mezarina García

- Guía del proceso emancipador 1780-1866, de Eric Koechlin Febres

Ricardo Pinto-Bazurco Mendoza

\section{Apuntes Institucionales}

- Actividades, documentos y pronunciamientos (Período Enero-Abril de 2020) Andrés Rodríguez Delgado

\section{CALENDARio de SUCESOS INTERnaCIONALES}

- Calendario de sucesos internacionales (Período Enero-Abril de 2020) Jessica Castro Vargas 
Artículos 



\title{
El ROL DE LAS LÍNEAS DE BASE EN EL DERECHO DEL MAR Y EL PROCESO DE DELIMITACIÓN MARÍTIMA entre el Perú y Chile
}

\author{
THE ROLE OF THE BASELINES IN THE LAW OF THE SEA \\ AND THE MARITIME DELIMITATION PROCESS \\ Between Peru and Chile
}

Oscar Maúrtua de Romaña*

\section{RESUMEN}

El presente artículo desarrolla el rol de las líneas de base para la delimitación de los espacios marítimos de los Estados, conforme a la Convención de las Naciones Unidas sobre Derecho del Mar (CONVEMAR), así como su trascendencia para el Perú y para la demanda de sus legítimos reclamos ante la Corte Internacional de Justicia en la controversia marítima con Chile.

Embajador y Jurista. Graduado de la Pontificia Universidad la Católica del Perú (PUCP) como Bachiller en Humanidades. Licenciado en Derecho (Abogado) de la Universidad Nacional Mayor de San Marcos (UNMSM). Licenciado en Relaciones Internacionales de la Academia Diplomática del Perú (1968). Premio Nacional de Cultura, 1969. Postgrados de las Universidades de Oxford, Johns Hopkins y Comité Jurídico Interamericano de la OEA. Magíster en Gestión Pública por la Universidad Tecnológica del Perú - UTP (2018). Presidente de la Sociedad Peruana de Derecho Internacional (SPDI). Miembro del Consejo Consultivo de la Presidencia del Poder Judicial y de CENTRUM Católica. Ex Secretario General de la Presidencia de la República (todo el segundo gobierno del Arq. Fernando Belaunde Terry). Ex Vice Ministro y Secretario General de Relaciones Exteriores; y, ex Canciller de la República. 
Palabras clave: Líneas de base, derecho del mar, delimitación marítima, Perú, Chile, Corte Internacional de Justicia, Convención de las Naciones Unidas sobre Derecho del Mar.

\section{ABSTRACT}

This article develops the role of the baselines for the delimitation of the maritime spaces of the States, according to the UNCLOS, as well as its importance for Peru and for the demand of its legitimate claims before the International Court of Justice in the maritime dispute with Chile.

Keywords: Baselines, law of the sea, maritime delimitation, Peru, Chile, International Court of Justice, United Nations Convention on the Law of the Sea.

\section{INTRODUCCIÓN}

Al haber transcurrido ya seis años de la finalización del proceso contencioso de delimitación marítima entre el Perú y Chile, deviene importante resaltar el rol de las líneas de base en el Derecho del Mar en general y de forma particular, en el citado proceso ante la Corte Internacional de Justicia - CIJ. ${ }^{1}$

El presente artículo toma en cuenta tanto los aspectos técnico-jurídicos como los aspectos de la política interna, porque ambas apreciaciones me cupo al haber participado en mi calidad de Ministro de Relaciones Exteriores, en sacar adelante el proyecto de Ley $\mathrm{N}^{\circ} 28621$ "Ley de Líneas de Base del Dominio Marítimo del Perú" que el Presidente de la República envió al Congreso para su aprobación, lo que hizo el Legislativo el 3 de noviembre de 2005, esto es hace 15 años.

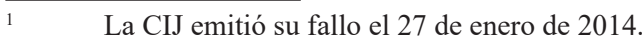




\section{LAS LÍNEAS DE BASE}

La Convención de las Naciones Unidas sobre el Derecho del Mar de 1982 - en adelante CONVEMAR- establece que las líneas de base son las líneas a partir de la cuales se mide el mar territorial, la zona contigua, la zona económica exclusiva y la plataforma continental y que nacen con el objeto de determinar la extensión de los distintos espacios marítimos de un Estado costero, ya que es fundamental determinar previamente desde dónde se miden estas zonas y de allí su funcionalidad. Las aguas interiores son las que se encuentran al interior de las líneas de base, en las cuales el Estado ribereño goza de soberanía, mientras que en los demás espacios marítimos, los demás Estados gozan de ciertos derechos.

Conforme a la Convención de Ginebra de 1958 y a la CONVEMAR, las líneas de base para medir el mar territorial y los demás espacios marítimos son de tres clases: la línea de base normal (regulada por el artículo $5^{\circ}$ de la CONVEMAR), las líneas de base rectas (reguladas por el artículo $7^{\circ}$ de la CONVEMAR) y las líneas de base archipelágicas (reguladas por el artículo $47^{\circ}$ de la CONVEMAR).

\subsection{La línea de base normal}

El Artículo $5^{\circ}$ de la CONVEMAR, establece:

"Artículo 5

Línea de base normal

Salvo disposición en contrario de esta Convención, la línea de base normal para medir la anchura del mar territorial es la línea de bajamar a lo largo de la costa, tal como aparece marcada mediante el signo apropiado en cartas a gran escala reconocidas oficialmente por el Estado ribereño."

Respecto a las cartas reconocidas oficialmente, cabe precisar que

"En todo el texto de la Convención el término "carta" significa una carta náutica utilizada por los marinos como ayuda para la navegación. Sólo las cartas náuticas indican todos los accidentes de interés, como por ejemplo las líneas de bajamar, las elevaciones en bajamar, los 
arrecifes emergentes, etc.” (Oficina de Asuntos Oceánicos y del Derecho del Mar-ONU, 1989:1).

A mayor detalle, Marisol Agüero señala que

“...hoy en día es muy común el empleo de la línea de bajamar correspondiente a la marea astronómica más baja (LAT), cuya definición ha sido acordada por la organización hidrográfica internacional como el datum de carta preferido para fines de navegación... En lo que concierne al segundo tema, en general se estima recomendable que las cartas utilizadas para mostrar la línea de bajamar se encuentren en el rango de entre 1:50 000 y 1:200 000, aunque algunos autores consideran que para tal propósito no deberían utilizarse cartas de una escala menor a 1:100 000..." (Agüero 2001: 172)

Por su parte, el profesor Saura nos explica lo siguiente:

"Suele citarse la Convención anglo-francesa sobre pesca, de 1839, como el primer instrumento internacional que describió la línea de bajamar como la línea de base normal a partir de la cual se mide el mar territorial. Se trataba en realidad de una precisión, permitida por el avance en los conocimientos técnicos, de una regla inmemorial conforme a la cual había que seguir el contorno de la costa para medir la anchura del mar territorial. Lo cierto es que la línea de bajamar viene citada como punto de partida para la medición del mar territorial en el Proyecto de Reglamento del Institut de Droit International de 1928, y que en la Conferencia de codificación de La Haya de 1930 dicha línea era ya considerada una expresión tradicional que, sin embargo, requería precisión. En la sentencia de la Corte Internacional de Justicia relativa al asunto de las pesquerías anglo-noruegas, que tanta influencia iba a tener en todo lo relativo a las líneas de base, se afirma que: 'The Court has no difficulty in finding that, for the purpose of measuring the breadth of the territorial sea, it is the low-water mark as opposed to the high-water mark, or the mean between the two tides, which has been adopted in the practice of States. This criterion is the most favourable to the coastal State and clearly shows the character of territorial waters as appurtenant to the land territory'. El único 
momento, a partir de entonces, en que se pone en duda si la línea de base normal debía coincidir en todo caso con la línea de bajamar, se produce en el seno de la Comisión de Derecho Internacional. Si bien los primeros informes del Relator Especial reproducen, en este ámbito, el principio establecido por la segunda subcomisión de La Haya, el Informe del Comité de Expertos al que la Comisión encargó el estudio de algunos aspectos técnicos relacionados con el Derecho del mar, introdujo un elemento distorsionador al afirmar que, efectivamente, la línea de base normal debía ser la línea de bajamar a lo largo de la costa tal como se halla indicada en las cartas a gran escala en servicio, reconocidas oficialmente por el Estado ribereño." (Saura, 1996)

\subsection{Las Líneas de base rectas}

Al respecto, el artículo $7^{\circ}$ de la CONVEMAR, dispone:

"Artículo 7

Líneas de base rectas

1. En los lugares en que la costa tenga profundas aberturas y escotaduras o en los que haya una franja de islas a lo largo de la costa situada en su proximidad inmediata, puede adoptarse, como método para trazar la línea de base desde la que ha de medirse el mar territorial, el de líneas de base rectas que unan los puntos apropiados.

2. En los casos en que, por la existencia de un delta y de otros accidentes naturales, la línea de la costa sea muy inestable, los puntos apropiados pueden elegirse a lo largo de la línea de bajamar más alejada mar afuera y, aunque la línea de bajamar retroceda ulteriormente, las líneas de base rectas seguirán en vigor hasta que las modifique el Estado ribereño de conformidad con esta Convención.

3. El trazado de las líneas de base rectas no debe apartarse de una manera apreciable de la dirección general de la costa, y las zonas de mar situadas del lado de tierra de esas líneas han de estar suficientemente vinculadas al dominio terrestre para estar sometidas al régimen de las aguas interiores. 
4. Las líneas de base rectas no se trazarán hacia ni desde elevaciones que emerjan en bajamar, a menos que se hayan construido sobre ellas faros o instalaciones análogas que se encuentren constantemente sobre el nivel del agua, o que el trazado de líneas de base hacia o desde elevaciones que emerjan en bajamar haya sido objeto de un reconocimiento internacional general.

5. Cuando el método de líneas de base rectas sea aplicable según el párrafo 1, al trazar determinadas líneas de base podrán tenerse en cuenta los intereses económicos propios de la región de que se trate cuya realidad e importancia estén claramente demostradas por un uso prolongado.

6. El sistema de líneas de base rectas no puede ser aplicado por un Estado de forma que aísle el mar territorial de otro Estado de la alta mar o de una zona económica exclusiva."

En su exégesis, la Oficina de Asuntos Oceánicos y del Derecho del Mar - ONU, precisó lo siguiente:

"El artículo 7 repite casi literalmente el artículo 4 de la Convención de 1958, que se originó en la sentencia dictada por la Corte Internacional de Justicia en el Caso de las Pesquerías Anglo-Noruegas. Se pueden trazar líneas de base rectas a lo largo de las costas que tengan profundas aberturas y escotaduras o en las que haya una franja de islas en su proximidad inmediata. Las líneas de base rectas deben trazarse de forma que cumplan requisitos relativos a la dirección general de la costa, su vinculación al dominio terrestre en el caso de las zonas marítimas que queden dentro de las líneas y vayan a quedar sometidas al régimen de aguas interiores, la utilización de elevaciones en bajamar y el acceso de otros países a sus zonas económicas exclusivas o al alta mar." (Oficina de Asuntos Oceánicos y del Derecho del Mar - ONU, 1989: 19).

\subsection{Las líneas de base archipelágicas}

Al respecto, el artículo $47^{\circ}$ de la CONVEMAR, establece:

"Artículo 47 
Líneas de base archipelágicas

1. Los Estados archipelágicos podrán trazar líneas de base archipelágicas rectas que unan los puntos extremos de las islas y los arrecifes emergentes más alejados del archipiélago, a condición de que dentro de tales líneas de base queden comprendidas las principales islas y un área en la que la relación entre la superficie marítima y la superficie terrestre, incluidos los atolones, sea entre 1 a 1 y 9 a 1 .

2. La longitud de tales líneas de base no excederá de 100 millas marinas; no obstante, hasta un $3 \%$ del número total de líneas de base que encierren un archipiélago podrá exceder de esa longitud, hasta un máximo de 125 millas marinas.

3. El trazado de tales líneas de base no se desviará apreciablemente de la configuración general del archipiélago.

4. Tales líneas de base no se trazarán hacia elevaciones que emerjan en bajamar, ni a partir de éstas, a menos que se hayan construido en ellas faros o instalaciones análogas que estén permanentemente sobre el nivel del mar, o que la elevación que emerja en bajamar esté situada total o parcialmente a una distancia de la isla más próxima que no exceda de la anchura del mar territorial.

5. Los Estados archipelágicos no aplicarán el sistema de tales líneas de base de forma que aísle de la alta mar o de la zona económica exclusiva el mar territorial de otro Estado.

6. Si una parte de las aguas archipelágicas de un Estado archipelágico estuviere situada entre dos partes de un Estado vecino inmediatamente adyacente, se mantendrán y respetarán los derechos existentes y cualesquiera otros intereses legítimos que este último Estado haya ejercido tradicionalmente en tales aguas y todos los derechos estipulados en acuerdos entre ambos Estados.

7. A los efectos de calcular la relación entre agua y tierra a que se refiere el párrafo 1, las superficies terrestres podrán incluir aguas situadas en el interior de las cadenas de arrecifes de islas y atolones, incluida la parte acantilada de una plataforma oceánica que esté 
encerrada o casi encerrada por una cadena de islas calcáreas y de arrecifes emergentes situados en el perímetro de la plataforma.

8. Las líneas de base trazadas de conformidad con este artículo figurarán en cartas a escala o escalas adecuadas para precisar su ubicación. Esas cartas podrán ser sustituidas por listas de coordenadas geográficas de puntos en cada una de las cuales se indique específicamente el datum geodésico.

9. Los Estados archipelágicos darán la debida publicidad a tales cartas o listas de coordenadas geográficas y depositarán un ejemplar de cada una de ellas en poder del Secretario General de las Naciones Unidas."

Conviene precisar que, conforme al artículo 46 de la CONVEMAR, por "Estado archipelágico" se entiende un Estado constituido totalmente por uno o varios archipiélagos y que podrá incluir otras islas. A su vez, por "archipiélago" se entiende un grupo de islas, incluidas partes de islas, las aguas que las conectan y otros elementos naturales, que estén tan estrechamente relacionados entre sí que tales islas, aguas y elementos naturales formen una entidad geográfica, económica y política intrínseca o que históricamente hayan sido considerados como tal.

Como observamos, el artículo $47^{\circ}$ contiene nueve párrafos dirigidos a regular el trazado de las líneas de base archipelágicas, las salvaguardias para los Estados vecinos que pudieren quedar afectados, y el registro y la publicación de las líneas de base archipelágicas (Oficina de Asuntos Oceánicos y del Derecho del Mar-ONU, 1989: 39).

\subsection{Importancia del trazado de las líneas de base}

Bien sostiene Saura que:

"Debemos decir que la importancia de las líneas de base en la delimitación de los espacios marítimos es insoslayable, puesto que, cualquiera que sea la figura a la que nos estemos refiriendo, la intervención de las líneas de base, por activa o por pasiva, se hace necesaria. Definidas inicialmente como cada uno de los puntos a partir de los cuales se mide la anchura del mar territorial, esa misma línea va a servir para medir la extensión de las aguas interiores, aguas 
archipelágicas, zona contigua, zona económica exclusiva y, en la mayoría de los casos, plataforma continental. Se entiende pues, que también para la delimitación de los espacios que no están sometidos a la soberanía o jurisdicción del Estado ribereño y que definen su extensión de forma residual haya que establecer claramente las líneas de base." (Saura, 1996)

Por tanto, la línea de base del mar territorial es la línea fundamental y primordial, entre todas aquellas que delimitan los espacios marítimos nacionales. A partir de la línea de base se van a calcular todas las zonas costeras que son definidas en términos de extensión, como lo es el mar territorial de 12 millas marinas (artículo $3^{\circ}$ de la CONVEMAR); la zona contigua de 24 millas marinas (artículo $33^{\circ}$, inciso 2 de la CONVEMAR); la zona económica exclusiva de 200 millas marinas (artículo $57^{\circ}$ de la CONVEMAR); la plataforma continental, en el caso que esta última sea definida hasta una distancia de 200 millas marinas (artículo $76^{\circ}$, inciso 1 de la CONVEMAR).

Por su parte, Alexander Antialón resalta lo siguiente:

"El establecimiento de las líneas de base es importante debido a que la posición de los espacios marítimos se define a partir de las líneas de base de las costas de los Estados. La Corte Internacional de Justicia ha enfatizado que "en primer lugar se debe determinar la costa relevante de las partes, a partir de la cual será determinada la ubicación de las líneas de base así como los pertinentes puntos base que permitirán que se trace la línea equidistante"." (Antialón 2008: 100)

\section{LASLIINEASDEBASEDELDOMINIOMARÍTIMODELPERÚ}

\subsection{La Ley $N^{\circ} 28621$ “Ley de Líneas de Base del Dominio Marítimo del Perú"}

Para proteger nuestras 200 millas, la Constitución peruana ha establecido que el Dominio Marítimo del Perú comprende el mar adyacente a sus costas,

2 Informes de la CIJ 2001, en Qatar - Bahrain, párr. 178. 
así como su lecho y subsuelo, hasta la distancia de 200 millas marinas (Art. 54 ${ }^{\circ}$ ). Asimismo, mediante Ley $\mathrm{N}^{\mathrm{o}}$ 23856, del 24 de mayo de 1984, se dio la denominación de "Mar de Grau" al Dominio Marítimo del Perú.

La línea costera del Perú, es decir, la línea que va de norte a sur o de sur a norte a lo largo de todo el Mar de Grau, tiene una extensión que se calcula en $3,079,50 \mathrm{~km}$. En tal sentido, para darle la formalidad jurídica que corresponde a la determinación de los puntos en la costa desde donde se proyectan las referidas 200 millas marinas hacia el límite exterior que comprende el Dominio Marítimo del Perú, el suscrito, en calidad de Ministro de Relaciones Exteriores, presentó al Presidente de la República, un proyecto de ley que fue aprobado por el Consejo de Ministros, reunido en Tacna, y por el Congreso de la República. En efecto, el 3 de noviembre de 2005 el Congreso de la República aprobó la Ley N² 28621 "Ley de Líneas de Base del Dominio Marítimo del Perú", elaborada de conformidad con lo establecido en el artículo $54^{\circ}$ de la Constitución Política y el Derecho Internacional.

Es bueno precisar que la ley peruana de "Líneas de Base del Dominio Marítimo" estuvo respaldada en la Constitución peruana de 1979, en su artículo $98^{\circ}$, que refería que "El dominio marítimo del Estado comprende el mar adyacente a sus costas, así como su lecho y subsuelo, hasta la distancia de doscientas millas marinas medidas desde las líneas que establece la ley". El mismo texto es conservado en la Constitución de 1993, en su artículo 54.

Estas líneas de base están fijadas en trazos de 200 millas marinas desde diversos puntos geográficos perpendiculares a la costa del Perú. En el sur, al superponerse con las 200 millas de Chile, se utilizó la bisectriz como método recomendado por la Convención del Mar, determinando las coordenadas WGS84 Latitud $18^{\circ} 21^{\prime}$ '08' Sur, Longitud $70^{\circ} 22^{\prime} 39^{\prime \prime}$ Oeste del punto Concordia como la línea base del límite marítimo. ${ }^{3}$

Como bien aprecia Antialón:

"En el anexo 1 de la Ley de líneas de base del dominio marítimo del

Vale recordar, nuevamente, que esta estratégica ley fue promulgada en el 2005, antes del proceso contencioso peruano-chileno ante la CIJ (2008-2014). 
Perú, se indican las coordenadas de los puntos de las líneas de base y asimismo se señala qué líneas de base se utilizó. De modo que se puede apreciar la utilización de las líneas de base normales y rectas. Esta mixtura de líneas de base están previstas en el artículo $14^{\circ}$ de la Convemar: "El Estado ribereño podrá determinar las líneas de base combinando cualesquiera de los métodos establecidos en los artículos precedentes, según las circunstancias"." (Antialón 2008: 101)

Asimismo, en la Memoria del Perú ante la CIJ por el contencioso con Chile, se precisó lo siguiente:

"En su mayoría, las líneas de base del Perú están constituidas por sus líneas de base "normales" que siguen la línea de bajamar a lo largo de su costa. Sin embargo, y tal como lo muestra el Gráfico 2.3, hay unas pocas áreas en la costa peruana en las que se ha establecido un sistema de líneas de base rectas. Todas estas áreas se ubican cerca o al norte de $\operatorname{los} 15^{\circ} \mathrm{S}$, es decir, a más de 200 millas marinas del límite terrestre con Chile. En consecuencia, están fuera del área de interés para los propósitos del presente caso. Como se observó previamente, dentro de las 200 millas marinas desde el punto de inicio de la frontera terrestre con Chile, la costa peruana es relativamente llana y sin complicaciones, además de no haber islas en esa área." (Ministerio de Relaciones Exteriores del Perú, 2014:79)

Como ya hemos señalado, la ley tomó como base el punto denominado "Concordia" pues corresponde al límite terrestre entre Chile y Perú en la costa, definido por el Tratado de Lima de 1929 y se ubica a diez kilómetros al norte del puente del río Lluta, medidos desde el centro del puente con un arco de circunferencia hasta cortar la costa en el mar. ${ }^{4}$

$4 \quad$ Tratado de Lima del 3 de junio de 1929, Artículo Segundo: "El territorio de Tacna y Arica será dividido en dos partes. Tacna para el Perú y Arica para Chile. La línea divisoria entre dichas partes y, en consecuencia, la frontera entre los territorios del Perú y de Chile, partirá de un punto de la costa que se denominará "Concordia", distante diez kilómetros al norte del puente del Río Lluta, para seguir hacia el oriente paralela a la vía de la sección chilena del Ferrocarril de Arica a La Paz y distante diez kilómetros de ella, con las inflexiones necesarias para utilizar, en la demarcación, los accidentes geográficos cercanos que permitan dejar en territorio chileno las azufreras del Tacora 
Cabe señalar que luego de la sentencia de la CIJ para el contencioso Perú-Chile (27 de enero de 2014), el Perú, respetuoso del derecho internacional y, en tal sentido, para adecuarse a dicho fallo, promulgó la Ley N 30223 "Ley que adecua la Ley 28621, Ley de líneas de base del dominio marítimo del Perú, según la delimitación marítima entre la República del Perú y la República de Chile, realizada por el fallo de la Corte Internacional de Justicia del 27 de enero de 2014. Dicha ley señala en su artículo 2:

“Artículo 2. Ámbito para la adecuación de la Ley 28621

La presente Ley se circunscribe estrictamente a adecuar la Ley 28621 conforme a lo resuelto por la Corte Internacional de Justicia en su fallo de fecha 27 de enero de 2014 sobre delimitación marítima con Chile, sin afectar de modo alguno la intangibilidad de la frontera terrestre ni del inicio de esta en el Punto Concordia, que se mantiene inalterable, en virtud de lo establecido en el Tratado de Lima entre el Perú y Chile, de fecha 3 de junio de 1929, su Protocolo Complementario y los trabajos de la Comisión Mixta de Límites de 1929 y 1930.”

Finalmente, cabe indicar que Chile ya en 1977 había determinado sus líneas de base entre los paralelos $41^{\circ}$ s. y $56^{\circ}$ s., es decir solo para la parte sur de su territorio. ${ }^{5}$ En el caso del Ecuador, este definió sus líneas de base en $1971 .{ }^{6}$

y sus dependencias, pasando luego por el centro de la Laguna Blanca, en forma que una de sus partes quede en el Perú y la otra en Chile. Chile cede a perpetuidad a favor del Perú, todos sus derechos sobre los canales de Uchusuma y del Mauri, llamado también Azucarero, sin perjuicio de la soberanía que le corresponderá ejercer sobre la parte de dichos acueductos que queden en territorio chileno después de trazada la línea divisoria a que se refiere el presente artículo. Respecto de ambos Canales, Chile constituye en la parte que atraviesan su territorio, el más amplio derecho de servidumbre a perpetuidad a favor de Perú. Tal servidumbre comprende el derecho de ampliar los Canales actuales, modificar el curso de ellos y recoger todas las aguas captables en su trayecto por territorio chileno, salvo las aguas que actualmente caen al Río Lluta y las que sirven a las azufreras del Tacora."

$5 \quad$ Mediante Decreto $N^{\circ} 416$ del 14 de julio de 1977.

$6 \quad$ Mediante Decreto Supremo N 959-A de fecha 28 de junio de 1971. 


\subsection{Reacción chilena a la ley peruana}

Con 98 votos a favor y ninguno en contra, el Congreso del Perú aprobó este proyecto, como ya he referido, el 3 de noviembre de 2005 y fue promulgado, por el presidente Alejandro Toledo, el mismo día. Se publicó en el diario oficial El Peruano el 4 de noviembre de 2005, convirtiéndose en la Ley $\mathrm{N}^{\circ} 28621$.

Esta ley constituyó un paso sustantivo en el proceso de preparación de toda la estrategia para demandar a Chile ante la Corte Internacional de Justicia. Por primera vez, nuestro país, contaba con una norma jurídica que establecía -oficialmente- las denominadas Líneas de Base. Sin duda, esta ley permitió, en la secuencia lógica, que dos años más tarde, mediante el Decreto Supremo No 047-2007-RE del 12 de agosto de 2007, el Perú aprobara la Carta del Límite Exterior -Sector Sur- de su dominio marítimo. ${ }^{7}$

Con ocasión de la aprobación de la ley de líneas de base, el Ministro de Relaciones Exteriores Subrogante de Chile envió una comunicación, el 28 de octubre de 2005, a la Embajada del Perú en Santiago, en la que señalaba que el proyecto de ley que estaba considerando el Congreso del Perú constituía

"un flagrante desconocimiento del límite chileno-peruano fijado por los tratados, como los de 1952 y 1954, así como de otros acuerdos que hacen referencia al paralelo que constituye el límite marítimo pactado entre ambos países e internacionalmente reconocido, el cual se origina en el Hito número uno. La situación planteada precedentemente, así como la eventual aprobación del mencionado proyecto, no es aceptable y carece de todo efecto jurídico para el Gobierno de Chile... debo señalar la firme decisión del Gobierno de Chile de continuar ejerciendo en plenitud los derechos soberanos y jurisdiccionales que le corresponden en los espacios terrestres y marítimos que le son propios, tal como lo ha venido haciendo desde su establecimiento al amparo,

Esta Carta fue registrada ante la Organización de las Naciones Unidas y constituyó un nuevo paso en el sentido de la estrategia nacional de cara hacia La Haya, lo que se materializó el 16 de enero de 2008 cuando el Perú planteó su demanda sobre delimitación marítima con Chile ante la Corte Internacional de Justicia, a fin de poner término a la controversia sobre límites marítimos existentes con dicho país. 
justamente, del derecho internacional y de los acuerdos que lo vinculan con el Perú y que este proyecto de ley pretende desconocer". ${ }^{8}$

En respuesta, el 31 de octubre, el suscrito respondió señalando que resultaba insólito en las relaciones entre Estados que uno de ellos formulara reservas a proyectos de ley de otro que se encuentran bajo la consideración del Poder Legislativo y que adicionalmente "advierta la inconveniencia de su aprobación”. En esa comunicación, califiqué esas apreciaciones del Gobierno chileno como inaceptables y contrarias al principio de no intervención. Señalé, asimismo, que el paralelo que alega Chile como punto de inicio de la frontera marítima no corresponde a la realidad jurídica y que los instrumentos que cita el Canciller chileno como fuentes de un supuesto límite marítimo (Declaración de Santiago de 1952, convenio sobre zona especial marítima de 1954), no han establecido los límites entre ambos países. ${ }^{9}$

Finalmente, como bien señala el Embajador Manuel Rodríguez Cuadros:

"A partir de este intercambio de notas, con la finalidad de deslindar la ubicación del punto de término de la frontera terrestre, el Canciller del Perú [Oscar Maúrtua de Romaña] invitó al Gobierno de Chile a que la Comisión mixta permanente de límites de ambos países procediera a verificar la exactitud de las coordenadas del punto final en la orilla del mar del arco de diez kilómetros de radio que constituye la línea limítrofe entre ambos países. En una nueva comunicación de fecha 3 de noviembre de 2005, el Gobierno de Chile reiteró su negativa a que la comisión mixta permanente de límites procediera a verificar las coordenadas. Esta negativa no se sustentó en una argumentación sólida, ya que no existe fundamento jurídico alguno para negarse a llevar a cabo un procedimiento técnico que tendría la virtud, al contrastar las actas demarcatorias de 1930 y la ubicación del punto Concordia en la orilla del mar, de verificar resultados de manera indubitable de la exacta posición del términus de la frontera terrestre." (Rodríguez 2010: 142) [El corchete es nuestro]

\footnotetext{
8 Comunicación del Ministro de Relaciones Exteriores Subrogante de Chile, Cristián Barros Melet, 28 de octubre del 2005.

9 Ministerio de Relaciones Exteriores del Perú, Nota a la Embajada de Chile del 31 de octubre de 2005.
} 


\section{CONCLUSIONES}

La importancia de las líneas de base en la delimitación de los espacios marítimos es indiscutible, puesto que, cualquiera que sea la clase de líneas de base a utilizar, su aplicación se hace necesaria para que a partir de los puntos de la línea se mida la anchura del mar territorial y, posteriormente, los demás espacios marítimos como son la zona contigua, la zona económica exclusiva y la plataforma continental.

En su mayoría, las líneas de base del Perú están constituidas por sus líneas de base "normales" que siguen la línea de bajamar a lo largo de su costa. Sin embargo hay unas pocas áreas en la costa peruana en las que se ha establecido un sistema de líneas de base rectas. De modo que se puede apreciar la utilización de las líneas de base normales y rectas. Esta mixtura de líneas de base están previstas en el artículo $14^{\circ}$ de la Convemar.

La Ley N 28621 "Ley de Líneas de Base del Dominio Marítimo del Perú" sobre nuestra soberanía nacional, además de precisar los linderos del Mar de Grau, expresó la voluntad política del Perú de ir ante la Corte Internacional de Justicia de La Haya para resolver este incordio. Expresó nuestra política nacional de disponer de nuestra estrategia para demandar a Chile, lo que fue abordado en sendos Consejos de Ministros, al mismo tiempo que se efectuaron diversas consultas a destacados peritos nacionales quienes confirmaron la solidez de nuestro reclamo. Por primera vez, nuestro país, contaba con una norma jurídica que establecía -oficialmente- las denominadas Líneas de Base. Sin duda, esta ley permitió, en la secuencia lógica, que dos años más tarde, mediante el Decreto Supremo N $^{\circ}$ 047-2007RE del 12 de agosto de 2007, el Perú aprobara la Carta del Límite Exterior -Sector Sur- de su dominio marítimo.

Siempre hemos dicho que el Perú es un país marítimo por naturaleza y por definición. Y eso es muy cierto. El Perú ha sido protagonista en la construcción del nuevo del Derecho del Mar mediante la revolucionaria tesis de las 200 millas marinas que se dio precisamente con el fin de proteger, conservar y reglamentar el uso de los recursos naturales existentes en el espacio marítimo en el que el Perú ejerce su soberanía y jurisdicción hasta las 200 millas del mar adyacente a sus costas. Por eso el Perú aprobó el 
Decreto Supremo No 781 del 1 de agosto de 1947. Nuestro país se constituyó así en uno de los países pioneros en lo que luego se denominaría la tesis de las 200 millas, adoptada como norma internacional en la Convención de las Naciones Unidas sobre el Derecho del Mar de 1982. Ello no fue producto del azar, sino resultado de la tenaz defensa mundial desarrollada a lo largo de décadas por los países del Pacífico Sur, tanto de manera individual como a través de la Comisión Permanente del Pacífico Sur, (CPPS) institución que cumplirá en agosto 68 años de existencia.

\section{BIBLIOGRAFÍA}

Agüero Colunga, Marisol. (2001). Consideraciones para la delimitación marítima del Perú. Fondo editorial del Congreso de la República. LimaPerú.

Antialón Conde, Alexander. (2008). Aspectos Jurídicos en la Controversia Marítima entre el Perú y Chile. Tesis para optar el título de abogado. Universidad Inca Garcilaso de la Vega.

Brousset Barrios, Jorge. (2015). El Punto Concordia es peruano. En: Revista Peruana de Derecho Internacional, Tomo LXV octubre-diciembre 2015, $\mathrm{N}^{\circ}$ 153.

Maúrtua de Romaña, Oscar. (2012). Las Lineas de Base en el Derecho del Mar y el Derecho Internacional de la Delimitación Marítima. Revista Peruana de Derecho Internacional, Tomo LXII setiembre-diciembre 2012, N 147, pp. 33-46. Lima-Perú.

Ministerio de Relaciones Exteriores del Perú. (2014). Delimitación Marítima entre el Perú y Chile ante la Corte Internacional de Justicia. Fondo Editorial del Congreso de la República.

Oficina de Asuntos Oceánicos y del Derecho del Mar - ONU. (1989). El Derecho del Mar. Líneas de Base. Examen de las disposiciones de la Convención de las Naciones Unidas sobre el Derecho del Mar relativas a las lineas de base. New York. 
Organización de las Naciones Unidas. (1982). Convención de las Naciones Unidas sobre el Derecho del Mar.

Rodríguez Cuadros, Manuel. (2010). La Soberanía Marítima del Perú. La Controversia entre el Perú y Chile. Derrama Magisterial.

Saura Estapá, Jaume. (1996). Límites del mar territorial. Barcelona: José María Bosch. Visto el 6 de junio de 2019 en: https://2019.vlex.com/\#WW/ $\operatorname{vid} / 277583$

Treves, Tullio. (2008). Convención de las Naciones Unidas sobre el Derecho del Mar. United Nations Audiovisual Library of International Law. Visto el 10 de junio de 2019 en: http://legal.un.org/avl/pdf/ha/uncls/uncls_s.pdf

Wojcikiewicz, Paula y Jean-Marc Sorel. (2017). Latin America and the International Court of Justice. Contributions to International Law. Routledge Research in International Law. 



\title{
La Justicia Social y el Derecho Internacional
}

\author{
Social Justice and International LaW
}

José Luis Pérez Sánchez-Cerro*

\section{RESUMEN}

La cesión de soberanía es parte del compromiso internacional que tienen los estados para establecer las coordinaciones entre los países y la construcción del derecho internacional. La justicia social es un elemento que no puede ser soslayado en las relaciones entre el hombre y el Estado y que tienen un peso propio en las sociedades modernas y, ahora, en las relaciones internacionales. Ella promueve, en lo posible, la igualdad social y los valores sociales fundamentales basado en el bien común equilibrado y armónico. Por ello, es importante prestar atención a los derechos sociales, a las causales de su deterioro y al origen del descontento popular, enfatizando en que la democracia y el respeto a los derechos humanos son mecanismos indispensables para la convivencia humana.

Embajador de Carrera. Doctor en Sociología Jurídica e Instituciones Políticas, Doctorado en Ciencia Política, Maestro en Diplomacia y Relaciones Internacionales con mención en Derecho de los Tratados, Abogado, Licenciado en Relaciones Internacionales. Ha cursado estudios de Derecho Internacional en Holanda y en Brasil; Derechos Humanos en Francia y de Relaciones Internacionales en Estados Unidos de América. Fue embajador del Perú en Colombia, España, Andorra, Alemania y Argentina y diplomático en las embajadas del Perú en los Estados Unidos de América, Ecuador, Venezuela, Costa Rica, España, Suecia y en la Organización de los Estados Americanos (OEA). Fue viceministro del Ministerio de la Presidencia, viceministro a.i. de Relaciones Exteriores y Secretario General de Relaciones Exteriores. Fue vicepresidente del Comité de Derechos Humanos de las Naciones Unidas (4 años). Fue presidente de la Asociación de Funcionarios Diplomáticos del Perú. Es Miembro Titular de la Sociedad Peruana de Derecho Internacional. 
Numerosas son las manifestaciones sobre el concepto de justicia social expresada a través de la historia de los pueblos, del derecho positivo, de las constituciones de los países y de algunas encíclicas papales.

John Rawls y Amartya Sen son dos de los filósofos que han marcado con sus teorías sobre la justicia social una etapa importante en el pensamiento y en el estudio de su significado en el mundo actual. Presento algunos de los planteamientos del filósofo indio Sen, especialmente sus enunciados más significativos en su obra "La idea de la Justicia". De otro lado, Sen analiza, desde una perspectiva diferente, la idea de justicia social de Rawls y critica algunas de las ideas más relevantes de su obra: "Teoría de la Justicia".

Palabra Clave: Individuo, costumbre internacional, organismo internacional, interdependencia internacional, individuo, equidad, justica social, bien común, arbitrariedad judicial, dignidad, democracia, derechos humanos.

\begin{abstract}
The transfer of sovereignty of states to be part of the concert of nations is part of the international commitment that states have to establish coordination between countries and the construction of international law. Social justice is an element that cannot be ignored in the relations between man and the State and have their own weight in modern societies and, now, in international relations. She promotes, as far as possible, social equality and fundamental social values based on the balanced and harmonious common good.
\end{abstract}

For this reason, it is important to pay attention to social rights, the causes of their deterioration and the origin of popular discontent, emphasizing that democracy and respect for human rights are indispensable mechanisms for human coexistence.

John Rawls and Amartya Sen are two of the philosophers who have marked with their theories on social justice an important stage in thought and in the study of its meaning in today's world. I present some of the approaches of the Indian philosopher Sen, especially his most significant statements in his work "The idea of Justice". On the other hand, Sen analyzes, from a 
different perspective, Rawls' idea of social justice and criticizes some of the most relevant ideas of his work: "Theory of Justice".

Keywords: Individual, international custom, international body, international interdependence, individual, equity, social justice, common good, judicial arbitrariness, dignity, democracy, human rights.

\section{INTRODUCCIÓN}

El derecho internacional moderno no sólo se limita a las relaciones interestatales como solía definirse antes. En el tema del Estado como sujeto de derecho internacional, solía ser la opinión mayoritaria de los tratadistas el sostener que es el sujeto de derecho internacional por excelencia junto a los organismos internacionales que constituyen el otro actor principal de esta rama del derecho. Sin embargo, la definición clásica del derecho internacional como conjunto de normas que rigen las relaciones entre los Estados, para algunos ha quedado ya superada a la luz del protagonismo alcanzado, como actor internacional, por el individuo en materia de derechos humanos, que si bien es cierto no tiene la capacidad para suscribir convenios o tratados con ningún Estado, en tanto que intuito personae, es diferente en naturaleza de los dos primeros sujetos (Estado y organismos internacionales), al ser, a diferencia del individuo, titulares de derechos que le capacitan para relacionarse con otros sujetos de derecho internacional. Solo en el caso del Derecho Penal Internacional el individuo es el sujeto responsable por los delitos cometidos contra el Derecho Internacional como autores o cómplices, es decir, consagra la responsabilidad penal internacional del individuo.

La Convención Interamericana sobre Derechos y Deberes de los Estados, de Montevideo de 1933, establece los requisitos que deben tener los Estados para que sean reconocidos como tales, el territorio definido, la población permanente, el gobierno y la capacidad de relacionarse con otros Estados y sujetos de derecho internacional. Esta convención ha servido para establecer la costumbre internacional en este aspecto. Sin embargo, 
la política internacional y el interés de algunos Estados han prevalecido en algunos casos como el de Taiwán, por ejemplo, que teniendo las características establecidas por la costumbre para constituirse en Estado, no se le reconoce como un Estado independiente, existiendo un bloqueo de una mayoría de países, que no quieren ver dañadas sus relaciones con China continental o su comercio, que optan por desconocerlo como Estado independiente y, por tanto, como sujeto de derecho internacional. Situaciones como esta, a las que podría sumarse, con algunas diferencias, el caso de Israel, por ejemplo, que también por razones políticas no es reconocido por todos los Estados, debilitando de alguna manera la costumbre internacional y los acuerdos internacionales por lo que el derecho internacional no ha podido, en algunos casos, librarse aun de su sujeción a los vaivenes de la política internacional.

En la actualidad, las relaciones internacionales son el reflejo de la tensión que existe entre la interdependencia internacional y la negativa de los gobiernos de ceder algo de su autoridad internacional a los organismos internacionales. Todo ello abona, a mi entender, la tesis de que son los Estados los que, en la práctica, constituyen los sujetos más fuertes de derecho internacional en menoscabo de los organismos internacionales y del individuo como sujetos válidos.

La pertenencia de Estados en organismos internacionales requiere, necesariamente, de una cesión de soberanía, especialmente en los campos de derechos humanos y de comercio, cesión que los Estados no siempre están dispuestos a dar, por lo que la validez de los organismos internacionales como sujetos de derecho internacional, aun cuando no se cuestiona, se ve disminuida frente a la preponderancia del interés de los Estados. Un claro ejemplo de ello en nuestro ámbito regional es el fracaso de todos los ensayos de esquemas de integración realizados hasta la fecha, sobre todo en América latina y en el ámbito mundial, la muy relativa coordinación que existe entre los países y el mantenimiento del derecho a un veto discriminatorio en el Consejo de Seguridad de las Naciones Unidas.

$\mathrm{Y}$ en cuanto al individuo como sujeto de derecho internacional, su consagración se encuentra en un buen momento a la luz de su capacidad para interactuar ante los órganos de protección internacional de los derechos 
humanos, aunque, su mayor aceptación dependerá de la evolución misma del derecho internacional y del momento y las circunstancias históricas que le otorguen una mayor o menor presencia. Hay posiciones extremas que van desde la escuela sociológica francesa que considera al individuo como el único sujeto de derecho internacional, en tanto que el Estado es solo un hecho que está compuesto por una asociación de individuos. Hay hasta quienes admiten que, al carecer de capacidad para celebrar tratados, el individuo es solo un sujeto pasivo del derecho internacional porque solo tiene ante él derechos y obligaciones. La idea del individuo como sujeto de derecho internacional tiene, en su aceptación más generalizada, el hecho de que éste tiene limitaciones y solo en ciertos casos es considerado como tal.

En cuanto al reconocimiento de gobiernos, cuando se trata de aquellos estados que son producto de una sucesión constitucional normal, este se hace ipso facto; contrario sensu, no es automático el reconocimiento y éste no se hará mientras no haya un amplio número de Estados que lo hagan. El elemento más importante en este proceso es que el nuevo gobierno tenga un control efectivo del Estado. En aras de la brevedad no entraremos a tratar las diversas doctrinas sobre reconocimiento de Estados y de gobiernos tales como la Estrada, la Tobar, la Betancourt, etc.

\section{LA JUSTICIA EN EL DERECHO INTERNACIONAL}

La justicia social es un valor que promueve el respeto igualitario de los derechos y las obligaciones de cada ser humano en determinada sociedad. Se enfoca, generalmente, en la repartición justa y equitativa de los bienes y servicios básicos necesarios para el desarrollo y el desenvolvimiento de una persona en la sociedad como, por ejemplo, el bienestar socioafectivo, la educación, la salud y los derechos humanos. El día mundial o internacional de la Justicia Social se celebra el día 20 de febrero. Este día fue establecido por la Organización de las Naciones Unidas (ONU) como una forma de conmemorar y velar por este valor social fundamental. La importancia de la justicia social radica en que fomenta la integración y la protección frente a la explotación de los más vulnerables para caminar hacia una sociedad 
más justa y equitativa. Al respecto la ONU sostuvo que "la justicia social es un principio fundamental para la convivencia pacifica y próspera" y que constituye "el núcleo de nuestra misión global para promover el desarrollo y la dignidad humana".

La justicia social se caracteriza por ser uno de los valores sociales más importantes en la sociedad que vela por el bien común y la convivencia armónica de la sociedad. La justicia está basada en el equilibrio entre el bien individual y el bien común basado en los valores humanos fundamentales. En este sentido, la justicia social enfoca sus esfuerzos en la búsqueda de la equidad en las diferentes cuestiones sociales.

El concepto de justicia social surge en medio de la segunda Revolución Industrial en el siglo XIX, justo antes de estallar la Primera Guerra Mundial. Los principios de la justicia social aparecen frente a la aparición de lo que se denomina la clase obrera frente a la explotación de ella por parte de la burguesía cuyos problemas se conoce como la cuestión social.

Dentro de lo que se conoce como justicia social, podemos encontrar conceptos como la justicia distributiva, término rescatado de autores como Aristóteles, indica el aporte que cada uno le debe a la sociedad. Por otro lado, existe la justicia retributiva que indica la imposición de la ley frente a los delitos que se cometen en determinada sociedad. Es importante recalcar que la justicia social sigue mayoritariamente los principios de los valores sociales fundamentales para el funcionamiento equilibrado y armónico en sociedad.

Hace algunos años participé en la Conferencia Ministerial de las Comunidades de Democracia celebrada en Filipinas en 1986. En ella planteé tres iniciativas. La primera, relativa a la necesidad de establecer mecanismos financieros innovadores para la defensa de la democracia y la gobernabilidad que permitan atender demandas sociales, impulsar el desarrollo económico y apoyar la estabilidad democrática y la gobernabilidad de la región. Dichos mecanismos tendrían por objeto habilitar recursos nuevos que, dentro del sistema financiero internacional, faciliten la inversión pública para promover la generación de empleo y asegurar las inversiones en educación y salud. Hoy más que nunca necesitamos de una alianza contra la pobreza, que sea, al mismo tiempo una alianza a favor de la democracia y de los derechos 
humanos. Los mercados funcionan mejor cuando hay democracia, cuando hay transparencia, cuando hay educación y cuando hay una adecuada equidad distributiva.

La segunda iniciativa fue la de convertir la Conferencia de Comunidad de Democracias en un foro internacional con carácter permanente, con participación de representantes de los partidos políticos y de la sociedad civil, además de representantes de Gobiernos, para enriquecer los debates al igual que la cooperación para el fortalecimiento democrático.

La tercera iniciativa estuvo orientada a establecer al interior de la Comunidad de Democracias, mecanismos para evaluar las desviaciones de los estándares democráticos que pudieran producirse en los países para evitar quiebres en la institucionalidad democrática. Esa tarea de monitoreo podría haber sido encomendada a los organismos de la sociedad civil.

En un interesante artículo del doctor Oscar Shiappa-Prieta sobre las sinrazones de las reparaciones civiles en los procesos penales, señala que existe una arbitrariedad judicial en la fijación del monto de estas, las cuales resultan ser no sólo bajísimas, sino que constituyen una violación a los derechos de las personas a repetir contra el Estado mediante un recurso efectivo. La arbitrariedad judicial en la determinación de reparaciones civiles y sus bajísimos montos, constituye una violación a los derechos humanos y al derecho de las personas a un debido proceso y a un juicio contra el Estado. Este es un aspecto que urge abordar dentro de la agenda de la reforma judicial porque el Estado peruano podría ser pasible de una denuncia ante el Sistema Interamericano de Derechos Humanos por ser coautor de violación masiva y sistemática.

Otro aspecto a tomar en consideración para una vida en dignidad es el de la atención prioritaria que merecen los derechos sociales. Nuestra región, en las últimas décadas, se ha visto seriamente influenciada por la presión ideológica del discurso neoliberal, que concibe una sola forma de asegurar el crecimiento económico, modelo que supuestamente nos traería prosperidad a todos. En dicho modelo, el capital y el libre mercado tienen total libertad de actuar y para ello es importante reducir la protección social y flexibilizar los derechos laborales que constituyen, supuestamente, obstáculos para el desarrollo económico. Luego de tantos años aplicando políticas neoliberales 
vemos que en los países andinos se ha profundizado la pobreza, ampliado el desempleo y precarizado las condiciones de trabajo.

Es indispensable que los Estados doten, en el más breve plazo, de eficacia jurídica a toda norma internacional adoptada en el marco de la protección de los derechos humanos para contar con legislaciones internas que garantice de manera efectiva los derechos sociales de todos sus ciudadanos. Debemos tener en cuenta que el mal funcionamiento del Estado y la mala gobernabilidad originan descontentos populares que desestabilizan las democracias en nuestra región.

Esa preocupación por el aspecto social, ha motivado que el Gobierno peruano presente iniciativas ante las Naciones Unidas orientadas a otorgar mayor importancia a los derechos sociales. De esta manera, a iniciativa del Perú, se aprobó ante la Asamblea General de la ONU una resolución sobre derechos humanos y pobreza en la cual los Estados reconocen que la existencia de la pobreza y la pobreza extrema, inhibe el goce pleno y efectivo de los derechos humanos.

Diversos autores han presentado nociones y definiciones sobre los derechos humanos que, en resumen, pueden ser definidos como un conjunto de facultades, prerrogativas y libertades fundamentales inherentes a la dignidad humana. En ese marco, el Estado peruano entiende que los lineamientos fundamentales de su política interna y exterior, están orientados a preservar el pleno respeto a los derechos humanos, al Estado de derecho y la democracia como forma de Gobierno. Asimismo, a promover el fortalecimiento de los sistemas internacionales de protección de derechos humanos a los cuales el Perú está integrado, tanto en el ámbito interamericano (OEA) como en el universal (ONU) y fomentar la correspondiente universalización de los instrumentos internacionales respectivos.

Cabe señalar que existen tratadistas que han considerado que en el tema de los derechos humanos se ha presentado un fenómeno particular en cuanto se ha podido arribar a la presencia de una opinio juris, es decir, la existencia de un sentimiento de obligatoriedad por parte de los Estados, sin la necesidad de una práctica reiterada en el tiempo. También se habla de una costumbre automática en torno al tema de los derechos humanos, a diferencia de lo que tradicionalmente ha constituido la costumbre internacional como fuente del 
derecho, entendida como la convergencia de una práctica prolongada y de la ya mencionada opinio juris. Es así como la Declaración Universal, que formalmente no tendría por qué obligar a los Estados porque no se trata de un tratado sino de una resolución de las Naciones Unidas (Resolución 217 A (III)) se trata de un ideal orientativo para la humanidad que se ha convertido en un instrumento cuyo incumplimiento se considera inaceptable internacionalmente.

Por ello, esta Declaración es considerada en la actualidad como el fundamento de todo el sistema de Naciones Unidas en materia de derechos humanos, porque ha ejercido una profunda influencia en el pensamiento y el comportamiento de las personas y de los gobiernos en todo el mundo y se la tiene como código de conducta y como patrón para medir el grado de respeto y aplicación de las normas internacionales en materia de derechos humanos.

Adicionalmente, cabe señalar la existente e innegable interrelación entre la democracia y los derechos humanos porque aquella constituye un elemento esencial para lograr la plena vigencia de los derechos humanos. Así lo han entendido los Estados, razón por la cual han incorporado los principios democráticos en los principales instrumentos internacionales.

La internacionalización de los derechos humanos se da como un proceso en el que estos son aceptados por la mayoría de los países del mundo y se obligan al cumplimiento de diversos instrumentos internacionales referidos a la protección y promoción de los derechos humanos, los cuales devienen exigibles para los protegidos y de cumplimiento obligatorio para los estados. Este proceso supuso la aparición de sistemas y mecanismos de protección internacional y la transformación de los principios establecidos en la Declaración Universal y en las disposiciones convencionales para establecer obligaciones jurídicas entre los estados. Las convenciones y los tratados internacionales a nivel universal y regionales, consagraron de esta manera el respeto y la protección de los derechos humanos, tanto en el ámbito internacional como en las legislaciones internas de cada Estado, expresando la obligación de estos de adecuar sus normativas nacionales a los estándares internacionales establecidos en los tratados.

Esta situación dio lugar a garantizar un estándar mínimo en el marco del Derecho Internacional de los Derechos Humanos, que el derecho interno de 
cada Estado debe complementar, fijando límites, criterios de interpretación y derechos constitucionales, entre otros aspectos y, principalmente, un cambio en el concepto clásico de soberanía de los estados. Asimismo, la Convención de Viena de 1969 sobre el Derecho de los Tratados, estableció en su artículo $53^{\circ}$ el principio de Jus Cogens, es decir, normas jurídicas internacionales superiores a la voluntad individual de los Estados, aceptadas y reconocidas por la comunidad internacional en su conjunto y derivadas del consenso general de los Estados y referidas a ciertos valores jurídicos que no admiten pacto en contrario.

Pero la conquista más importante del Derecho Internacional de los Derechos Humanos es la inserción del hombre, del individuo, como sujeto de Derecho Internacional; es decir la prevalencia de la norma más favorable a la protección de la persona, sea que esta provenga del derecho interno o del derecho internacional. Así lo han expresado de manera taxativa, el Pacto Internacional de los Derechos Civiles y Políticos (art. 5. $2^{\circ}$ ), la Convención Americana de Derechos Humanos (art. 29 $9^{\circ}$, la Convención contra la Tortura y otros tratos o Penas Crueles, Inhumanas o Degradantes (arts. $1^{\circ}, 14^{\circ}$ y $16^{\circ}$ ), entre otros convenios y tratados.

El respeto y protección de los derechos humanos y del derecho al desarrollo, constituyen en la actualidad, pilares fundamentales en la política nacional y exterior del Estado peruano. La defensa de la libertad, del sistema democrático, del Estado de derecho y la lucha contra la pobreza, son sus principales objetivos. Por ello promueve el fortalecimiento de los sistemas internacionales de protección de los derechos humanos de los que es Estado parte, tanto en el ámbito interamericano como en el universal como objetivos de política exterior irrenunciables.

Para la política exterior peruana, la democracia, el desarrollo y el respeto a los derechos humanos son interdependientes y se refuerzan mutuamente. De igual manera, siendo que los derechos humanos son indivisibles e interdependientes, le presta igual y urgente atención a la aplicación, promoción y protección tanto de los derechos civiles y políticos como de los económicos, sociales y culturales y el derecho al desarrollo. 


\section{ALCANCES DE LA JUSTICIA SOCIAL}

La justicia social es un valor que promueve el respeto igualitario de los derechos y las obligaciones de cada ser humano en determinada sociedad. La justicia social se enfoca generalmente en la repartición justa y equitativa de los bienes y servicios básicos necesarios para el desarrollo y el desenvolvimiento de una persona en la sociedad como, por ejemplo, el bienestar socioafectivo, la educación, la salud y los Derechos Humanos.

La justicia social se caracteriza por ser uno de los valores sociales más importantes en la sociedad. Vela por el bien común y la convivencia armónica de la sociedad en que se vive y por el equilibrio entre el bien individual y el bien común basado en los valores humanos fundamentales. En este sentido, la justicia social enfoca sus esfuerzos en la búsqueda de la equidad en las diferentes cuestiones sociales que aún son necesarias resolver.

De manera general, la justicia social implica la creación y aplicación de leyes que permiten que ella funcione. La equidad social, en cambio, abarca todo tipo de igualdad, sean ellas escritas o no, apelando a la justicia moral.

La desigualdad de ingresos, los altos niveles de desempleo y pobreza, la vulnerabilidad de las economías ante las crisis externas y el aumento tanto del trabajo no protegido como de la economía informal siguen siendo retos no superados. Es decir, estamos muy lejos de la aspiración universal de justicia social, que significa alcanzar el pleno empleo, asegurar la sostenibilidad de sociedades abiertas y de la economía mundial, lograr la cohesión social y erradicar la pobreza y las crecientes -viejas y nuevas- desigualdades. Realmente, estamos hablando de algo tan simple en teoría y a veces tan complejo de conseguir como la dignidad humana.

Justicia es una palabra con una carga que esconde discursos y prácticas que junto a otras como ciudadanía, democracia, bienestar, comunidad, reconocimiento, derechos, equidad, etc. Configura una trama colmada de contradicciones y pugnas que se ubica muy lejos de la aparente asepsia del mundo conceptual y que solo se asumen como sustrato de la justicia social. 
El artículo 1ro de la de la Constitución de la OIT de 1919, señala que "considerando que la paz universal y permanente solo puede basarse en la justicia social" y partir de ese punto, su discusión entra al discurso jurídico y académico. En 1931, la noción de justicia social se incorpora plenamente a la doctrina social de la Iglesia Católica, al utilizarla el papa Pío XI en la Encíclica "Quadragesimo anno" quien dijo que la justicia social es un límite al que debe sujetarse la distribución de la riqueza en una sociedad, de modo tal que se reduzca la diferencia entre los ricos y los necesitados.

El concepto mantuvo su influencia, particularmente con su promoción por filósofos como John Rawls, estadounidense, a quien estudié durante un año entero en el doctorado en Ciencia Política que realicé en la Universidad Central de Venezuela en los noventas. Aunque el significado de justicia social hoy varía, al menos hay tres elementos comunes que pueden ser identificados en las teorías contemporáneas: un deber del Estado de distribuir ciertos medios mínimos vitales (como derechos económicos, sociales y culturales, por ejemplo), la protección de la dignidad humana y las acciones afirmativas para promover la igualdad de oportunidades.

La "Teoría de la justicia" es un libro sobre filosofía política y moral escrito por John Rawls. La teoría resultante se conoce como "Justicia como equidad", de la cual Rawls deriva sus dos célebres principios de justicia: el principio de la libertad y el principio de la diferencia. Rawls supone que en la posición original las partes están situadas bajo un velo de ignorancia. En efecto, nadie conoce su lugar en la sociedad, su posición de clase o estatus social, y tampoco nadie conoce su suerte en la distribución de activos y habilidades naturales, su inteligencia, su fuerza, y cosas similares. Los principios de justicia se eligen detrás de un velo de ignorancia cuyo objetivo es que la posición inicial de los participantes sea imparcial. De acuerdo a Rawls, entonces, la ignorancia de estos detalles sobre sí mismo conducirá a principios que sean justos para todos. Si un individuo desconoce cómo terminará en su propia concepción de la sociedad, es probable que no privilegie a una determinada clase de personas, sino que más bien desarrolle un esquema de justicia que trate a todos justamente. Los únicos hechos particulares que conocen las partes son que su sociedad está sujeta a las circunstancias de la justicia, con todo lo que ello implica. 
Amartya Sen continúa a Rawls pero se aparta de él en cuestiones esenciales. Un punto importante es que Sen tiene más en cuenta el contexto y la pregunta por la justicia en el ámbito internacional. En el tema "La justicia y el mundo" aflora en toda la obra y es uno de los motivos por los que le parece insuficiente la propuesta del autor de "Teoría de la Justicia" es que el problema de la justicia es demasiado centrado a un solo país.

No hay que olvidar que una parte central del trabajo de Sen que le valdría el Premio Nobel, fue el estudio económico de las grandes hambrunas (Sen, 1982), de las que tuvo experiencia directa por haber vivido la que se produjo en la India, su país, en 1943. La reflexión que Sen realiza sobre la justicia sigue en parte los caminos trazados por John Rawls, autor a cuya memoria el libro está dedicado. Sen considera a Rawls "el principal filosofo de nuestro tiempo". Ambos son liberales igualitarios, es decir socialdemócratas, y ambos se proponen elaborar una teoría de la justicia. Más allá de la visión compartida sobre el papel que le cabe al Estado en lograr un mínimo de justicia social, ambos se proponen elaborar una teoría de la justicia en la que comparten la convicción de que resulta posible usar la razón en este campo.

Para Sen, Rawls es uno de los más importantes tratadistas de la filosofía política y su obra "Teoría de la justicia" constituyó un referente en ese campo. Sen emprende un análisis exhaustivo de dicha obra, recorriendo con impresionante maestría el pensamiento filosófico-político desde la Ilustración hasta nuestros días y examinando, rebatiendo, validando muchos de los postulados de Rawls y, a través de él, algunos de los tratadistas de la Ilustración, base de la obra de Rawls. La idea de la justicia ha sido objeto de una gran atención en los medios académicos del mundo entero y objeto de numerosos comentarios y reseñas. En esta obra, con la modestia y honestidad que caracteriza a Sen, se aborda de una manera crítica y sistemática la "Teoría de la justicia" elaborada por John Rawls. En las propuestas de Rawls se van desarrollando y concretizando a lo largo de una amplia obra que si bien causó un impacto en el quehacer teórico y académico, sobre todo en el mundo anglosajón, tal vez en la práctica no tuvo ese mismo resultado, aun cuando hay quienes han considerado que la obra de Rawls “....es fundamental en la interpretación del derecho, pues el modelo basado en principios -y orientado por políticas públicas- es, hoy por hoy, el 
estilo dominante de análisis jurídico e imprescindible para comprender el desarrollo del constitucionalismo moderno".

Como quiera que sea, alguien que venía reflexionando sobre el tema de la justicia, como era el caso de Sen, no podía dejar de abordar este asunto, buscando un nuevo enfoque que permitiera trascender los planteamientos teóricos de Rawls y otros, de manera tal que la reflexión teórica desarrollada por los académicos pudiera tener un impacto en el quehacer cotidiano de los ciudadanos, de los gobiernos y de la comunidad internacional.

Lo que importa resaltar es el camino seguido por Sen a fin de conducirnos del ámbito personal, comunitario y/o nacional a un ámbito más grande, al internacional o global, a los procesos que deben permitir la realización de la justicia mediante el combate de las injusticias flagrantes y lacerantes de nuestro mundo. Por ello Sen se ha esforzado a lo largo de su libro "La idea de la justicia" a responder la cuestión clave es decir de ¿cómo promover la justicia?, más allá de buscar cómo crear o establecer instituciones justas.

El énfasis en el concepto de "justicia social" en la teoría de la justicia moderna en comparación con el alcance más amplio de la teoría clásica de justicia refleja un cambio general en el que la teoría de la justicia se ha convertido en una preocupación que atañe más a los filósofos políticos que a los juristas.

Sen y Sandel, filósofo político y profesor estadounidense, señalan que, como teorías modernas en general, se centran en el caso específico de la justicia social, que no es más que una forma de justicia distributiva. Para Aristóteles, la justicia distributiva surge cuando se emprenden acciones sobre una propiedad conjunta o común para ser distribuida entre quienes comparten la propiedad de la misma. Hay muchas situaciones en las que la justicia distributiva está en juego; funciona donde hay cualquier distribución, según algún criterio, de lo que es una propiedad común entre quienes la poseen. Por ejemplo, accionistas de una empresa que reciben un dividendo anual según un criterio, en este caso, según el número de acciones poseídas. Otro ejemplo son los casos de separación o divorcio, donde la propiedad común se distribuye entre las partes según criterios legalmente establecidos. 
Estos son casos de justicia distributiva clásica, pero no de la justicia social moderna.

"La idea de justicia" de Sen, tiene que ver con el desarrollo de los valores del transnacionalismo, cosmopolitismo y el pluralismo, que han hecho que la teoría de la justicia social, todavía pueda tener una importante influencia sobre el tema, capaz de rivalizar con la de Rawls. Aunque cada uno de ellos pertenece a una tradición que se centra demasiado en un sólo tipo específico de justicia, que es la de la tradición clásica, que sigue siendo la más completa explicación de la justicia.

Lo expresado por Thomas Piketty, un economista francés especialista en desigualdad económica y distribución de la renta. corresponde a lo que años atrás había manifestado Sen, en el sentido de que la obra de Rawls, en general, y en su libro "La idea de la justica", en particular, han buscado tener un impacto en la lucha real para la realización de la justicia, partiendo de la idea de que más que construir un sistema ideal de justicia se deben buscar los mecanismos que permitan luchar contra la injusticia, y por ese conducto contribuir a la realización de la justicia. Por ello, ha habido quienes consideran que "La idea de la justicia", su última obra, es más un tratado de lucha contra la injusticia que un planteamiento teórico de la justicia. En todo caso, como el propio Sen lo reconoce: "En contraste con casi todas las modernas teorías de la justicia, que se concentran en "la sociedad justa", este libro ("La idea de la justicia") es un intento de investigar comparaciones basadas en realizaciones que se orientan al avance o al retroceso de la justicia".

Por su lado, Luis Pazos, escritor mexicano sostiene que: "Si los gobernantes no respetan la integridad personal, el patrimonio y la libertad de decidir de cada persona, aunque hayan ganado una elección, no se les puede calificar de demócratas o republicanos". Pazos cuestiona la manipulación del concepto de justicia social y sostiene que la justicia social se contrapone a la justicia a secas, ya que implica la violación al derecho humano de la propiedad, premisa fundamental del nacimiento de nuestra civilización. Así, demuestra que "A mayor gasto social, más pobreza" y señala los casos de Argentina, España y México donde el aumento de gasto social ha incrementado el número de pobres y desempleados. 
En cuanto a la justicia social en nuestro medio, entre otras razones, debido a los altos costos de tasas judiciales, formularios y procesos, gran parte de la población se ve privada de su derecho a un juicio justo. El nuestro es un país donde una gran cantidad de población vive en una situación de pobreza extrema o pobreza, no es posible que se espere que las personas puedan acceder a este derecho, con la actual situación económica que existe en el poder judicial. Incluso para ciudadanos que pueden pagar los costos de la defensa letrada, resulta tedioso e incómodo desperdiciar esa plata en procesos que, probablemente, demuestren ser ineficientes con el tiempo.

Por ello, es necesario implementar una cultura de concientización política en el país que haga que las autoridades se den cuenta que, ante la incapacidad de proveer a la ciudadanía con derechos individuales, soluciones efectivas, procesos rápidos, con respeto a la pluralidad cultural, social y lingüística, es imposible que nos consolidemos como un Estado-nación que se jacta de ser democrático frente a los mismos ciudadanos a los que les niegue el derecho a ejercer la defensa letrada de sus derechos.

\section{BIBLIOGRAFÍA}

Abramovich, V. Courtis, C. (2002), Derechos sociales como derechos exigibles, Madrid: Trotta.

Ackerman, B. (1993), La justicia social en el estado liberal, Madrid: Centro de Estudios Constitucionales.

Barden G. (1999), Essays on a Philosophical Interpretation of Justice: The Virtue of Justice, Mellen, Lampeter.

Barriga Mendoza, María Isabel. La Pobreza del Perú. Instituto De Los Andes En http://www.monografias.com/trabajos7/pope/pope.shtml

Campos Ponce, Rosa Luz. 2008 Análisis Cualitativo de la Pobreza en la zona rural del Departamento de Junín. Tesis para optar el grado de doctor en Economía. Universidad Nacional Mayor de San Marcos, Escuela de Post grado Facultad de Ciencias Económicas Unidad de Post Grado. 
Hobbes, T. (1968), Leviathan, CB Macpherson (ed), Penguin, Harmondsworth.

Jackson B. (2005), "The Conceptual History of Social Justice", Political Studies Review, núm. 3, pp. 356-373.

El concepto de derechos sociales fundamentales, Bogotá: Universidad Nacional de Colombia/Legis. (2OO5).

OXFAM. 2011 Informe Perú 2010-2011: Pobreza, desigualdad y desarrollo en el Perú. Ed. Oxfam.

Rawls, J. (1971), A Theory of Justice, Harvard University Press, revised edition (1999), Cambridge, Mass.

Sandel, M. J. (1982), Liberalism and the Limits of Justice, Cambridge University Press, Cambridge.

Sandel, M. J. (2009), Justice: What's the Right Thing to Do?, Farrar, Straus \& Giroux, New York.

Sen, A. (2009), The Idea of Justice, Allen Lane, London.

Verdera V, Francisco. La pobreza en el Perú: un análisis de sus causas y de las políticas para enfrentarla. Ed. Colección CLACSO COEDICIONES/Becas de Investigación. En http://biblioteca.clacso.edu.ar/ar/libros/coedicion/ verdera/ 



\title{
CONVENIO SOBRE ARREGLO DE DIFERENCIAS RELATIVAS A INVERSIONES ENTRE ESTADOS Y NACIONALES DE OTROS ESTADOS (CIADI)
}

\author{
Convention of THE SETTLEMENT OF INVESTMENT DisPUTES BETWEEN
} STATES AND NATIONALS OF OTHER STATES (ICSID)

\section{Gonzalo García Calderón Moreyra*}

\section{RESUMEN}

El artículo explica el funcionamiento del Centro Internacional de Arreglo de Diferencias Relativas a Inversiones entre Estados y nacionales de otros Estados, teniendo en cuenta la importancia de dicho centro en la solución de conflictos hoy en día en el Perú.

Palabras clave: Tratado de Washington de 1965. CIADI. Convenio Arbitral. Árbitros. Procedimiento arbitral.

\footnotetext{
Abogado y Magíster en Derecho Internacional Económico por la Pontificia Universidad Católica del Perú. Fundador y socio de García Calderón Asociados. Miembro de la Comisión Reformadora de la Ley de Títulos y Valores y de la Ley de Arbitraje. Ex director de la Cámara de Comercio de Lima. Arbitro Internacional y Nacional de la lista de la Cámara de Comercio de Lima, de la Pontificia Universidad Católica del Perú, de la Cámara Americana (AMCHAM) y del Organismo de Contrataciones del Estado. Miembro Titular de la Sociedad Peruana de Derecho Internacional.
} 


\section{ABSTRACT}

The article explains the operation of the International Center for Settlement of Investment Disputes between States and nationals of other States, taking into account the importance of this center in the resolution of conflicts in Peru today.

Keywords: 1965 Washington Treaty. ICSID. Arbitration Agreement. Referees. Arbitration procedure.

Siempre es importante recordar que el Perú forma parte de la comunidad internacional y se inserta jurídicamente mediante Convenios y/o Tratados, sean estos bilaterales o multilaterales. En materia de comercio exterior tiene celebrados Tratados Bilaterales de Inversión, Tratados de Libre Comercio, además de formar parte de la Organización Mundial de Comercio (OMC), de la Comunidad Andina, del Foro de Cooperación Económica Asia Pacífico, entre otros. Gracias a formar parte de este mundo globalizado ha podido recibir inversiones extranjeras de muchísimos países tan alejados no solo físicamente sino jurídicamente como China, Australia, Estados Unidos, entre otros muchos y es natural que puedan surgir conflictos entre el Estado peruano y los nacionales inversores de esos otros Estados, es por ello que la comunidad internacional ha establecido mecanismos comunes transnacionales de solución de controversias.

Para el caso de conflictos que puedan darse entre inversiones efectuadas por nacionales de otros Estados en el Perú y el Estado peruano existe un marco de solución multilateral que permite que neutrales resuelvan dicho conflicto mediante el uso de la conciliación y el arbitraje.

En efecto, el CIADI como se señala en su documento fundacional "fue abierto a la firma de todos los Países miembros del Banco Internacional de Reconstrucción y Fomento el 18 de marzo de 1965. El 14 de octubre de 1966, treinta días después de haber sido depositado en el Banco el vigésimo instrumento de ratificación, el Convenio entró en vigencia de acuerdo con su artículo 68(2)". 
Es necesario señalar que se trata de un medio casi universal en la medida que está ratificado por más de 160 países de todos los continentes. Se puede ver la lista de los países miembros en la página web del CIADI ( http:// icsid.worldbank.org). El Perú lo firmó el 4 de setiembre de 1991 efectuando el depósito del instrumento de ratificación el 9 de agosto de 1993, entrando en vigencia el 8 de septiembre de 1993.

El Perú ha sido demandado en casi dos docenas de casos desde su vigencia hasta la fecha en materias tan disímiles como inversión en petróleo, energía, gas, minería, electricidad, infraestructura vial, aeroportuaria, portuaria etc. En respuesta a ello, el Estado Peruano ha implementado un Sistema de Coordinación para las controversias internacionales en materia de inversión conocido como SICRESI (creado mediante Ley No 28933 del 15 de diciembre de 2006), el mismo que ha dado muy buenos resultados en la defensa de los intereses nacionales, lo cual incluso, ha merecido un informe favorable de la UNCTAD del año 2011 (Best Practices in investment for development: How to prevent and manage investor-disputes. Lessons from Peru).

Este convenio celebrado por los Estados permite que las controversias sean resueltas de una manera pacífica, dentro del marco de un debido proceso con las garantías de imparcialidad e independencia que se espera de un tribunal de justicia.

\section{ORIGEN Y FINALIDAD}

Los inversionistas extranjeros que invierten en el Perú o en cualquier otro Estado, esperan que determinadas reglas legales se respeten mientras dure su inversión, sin embargo muchas veces las reglas de juego son modificadas por los Estados generándose un perjuicio al inversionista que se ve impedido -entre otros ejemplos- de remesar utilidades al exterior, o se establecen tipos de cambio diferenciados, o se aumenta la tasa impositiva, o se generan inconvenientes para acceder a las importaciones o exportaciones de bienes o servicios, o incluso se producen casos de expropiación sean estas expropiaciones de naturaleza directa o indirecta que afectan o perturban el desarrollo de la inversión extranjera en un Estado determinado. 
En todos los supuestos antes señalados se genera un conflicto entre Inversionista-Estado y ocurre que cuando uno tiene un conflicto con otra persona, sea natural o jurídica, debe ventilarse dicho conflicto ante el Poder Judicial.

Sin embargo, en estos casos de inversión extranjera resulta que el Poder judicial es parte del Estado al cual el inversor extranjero quiere o pretende demandar, por lo que se hace difícil -para el inversionista- creer en la independencia absoluta de un poder de un Estado respecto a otro poder del mismo Estado que adoptó la decisión, sin que pueda existir influencia o presión o nacionalismos que afecten el debido proceso y la seguridad jurídica que se espera.

Es por ello que históricamente en muchas ocasiones el inversionista extranjero recurría a la protección diplomática o a reclamaciones del Estado del inversionista para que presione diplomáticamente al Estado receptor de la inversión, llegándose incluso al uso de la fuerza.

La finalidad u objetivo del CIADI mediante este mecanismo de solución de conflictos es pues, permitir someter la controversia a un tribunal imparcial ajeno al domicilio del Estado receptor de la Inversión y de preferencia con árbitros de nacionalidad distinta a los involucrados, bajo el manto de una institución prestigiosa como lo es el Banco Mundial, desarrollándose dentro de un procedimiento que garantice un trato igualitario tanto a inversionistas como a los Estados y que las decisiones tengan el carácter de cosa juzgada.

El propio convenio establece en su artículo 27 que "Ningún Estado Contratante concederá protección diplomática ni promoverá reclamación internacional respecto de cualquier diferencia que unos de sus nacionales y otro Estado contratante hayan consentido en someter o hayan sometido a arbitraje conforme a este convenio, salvo que este último Estado no haya acatado el laudo dictado en tal diferencia o haya dejado de cumplirlo". 


\section{COMPETENCIA}

Qué duda cabe que este foro es consciente que debe limitar la competencia del Centro estableciéndose que sólo se someterán las diferencias surgidas de una inversión efectuada por un nacional extranjero de un país miembro y un Estado miembro receptor de dicha inversión. (Es necesario mencionar que, además de este convenio que se está analizando, existe un Reglamento denominado mecanismo complementario del CIADI para brindar servicios de conciliación y arbitraje a aquellos nacionales de otros Estados no miembros).

El tema competencial es un tema recurrente en los arbitrajes bajo administración del centro respecto a las excepciones que se pueden plantear con relación a la competencia del CIADI, sea en razón de la nacionalidad de las partes, sea en razón de la vigencia de la aplicación en el tiempo del sometimiento al CIADI y/o incluso sobre si se trata o no de una materia que debe ser considerada o no como una inversión.

Estas excepciones en razón de, la temporalidad, de la materia y en razón de la persona involucrada, son utilizadas como medio de defensa en muchas ocasiones por los Estados. El Estado Peruano ha utilizado todas estas excepciones en gran parte de sus casos, citaré algunos de ellos pero por razones de espacio no podré desarrollarlos:

i) Industria Nacional de Alimentos S.A. e Idelsa Perú S.A vs República del Perú.

ii) Duke Energy International vs República del Perú.

iii) Tza Yap Shum vs República del Perú.

iv) Convial Callao S.A. vs República del Perú.

v) Renee Rose Levy vs República del Perú.

vi) DP World Callao vs República del Perú.

vii) Lidercom vs República del Perú.

viii) Gramercy funds Mangement LLC vs República del Perú.

El centro puede, al igual que sucede en la mayoría de reglamentos de las instituciones arbitrales de carácter comercial, rechazar liminarmente la solicitud si considera que no existe convenio arbitral o sometimiento válido a la competencia del centro para conocer de la controversia. Esta decisión "Prima 
Facie" solo versa sobre la competencia del centro, ya que la competencia referida a las materias o nacionalidad o temporalidad serán resueltas por el propio tribunal arbitral bajo el principio del "KOMPETENZ KOMPETENZ" o competencia de los árbitros para resolver sobre su propia competencia.

En efecto el inciso (3) del artículo 36 señala que "El secretario General registrará la solicitud salvo que, de la información contenida en dicha solicitud, encuentre que la diferencia se halla manifiestamente fuera de la jurisdicción del centro. Notificará inmediatamente a las partes el acto de registro de la solicitud, o su denegación. Este artículo debe concordarse con el artículo 41 (1) del Convenio el cual señala que "El tribunal resolverá sobre su propia competencia".

\section{CONCILIACIÓN}

Solo para comentar de manera muy rápida que el Centro cuenta con un capítulo previo al arbitraje denominado de la Conciliación, para permitir a las partes arribar a un acuerdo negociado con el apoyo del centro. No es un paso previo o escalonado anterior al arbitraje, salvo que las partes lo hayan pactado de esa manera.

Muy similar a lo que ocurre en nuestro país con la Ley de Conciliación extrajudicial (Decreto Legislativo 1070) en donde el Estado no le ha dado el carácter de obligatorio a la Conciliación, previo al arbitraje, como sí lo ha hecho para determinadas materias que deben ser resueltas en el ámbito judicial, las cuales requieren, antes de acudir al órgano judicial competente, previamente, el inicio de un proceso de conciliación ante un centro de conciliación acreditado ante el Ministerio de Justicia, para solo en caso de no llegar a un acuerdo satisfactorio, acudir al Poder judicial.

Se trata de un mecanismo, según lo disponen las reglas del Centro salvo acuerdo en contrario de las partes- en donde actuarán tres conciliadores: uno designado por cada parte y el tercero designado de común acuerdo por los dos conciliadores, y en caso de no existir acuerdo, por el centro. Esta comisión de conciliadores debe estar integrada por personas de "amplia consideración moral, tener reconocida competencia en el campo del Derecho, 
del comercio, de la industria, o de las finanzas, e inspirar plena confianza en su imparcialidad y juicio".

La comisión podrá proponer fórmulas de acuerdo las veces que consideren necesario efectuarlo y lógicamente no se levantará un acta de lo acontecido en las reuniones, solo se levantará el acta dejando constancia de si se llegó o no a un acuerdo. Es fundamental que las partes tengan la libertad de poner sobre la mesa todas las opciones sin que ello signifique reconocimiento alguno, por lo que nada de lo que se discuta, oferte o declare al interior de la comisión puede ser utilizado luego en el procedimiento arbitral.

\section{EL ARBITRAJE}

Este procedimiento se inicia con una solicitud que debe ser dirigida por escrito al Secretario General donde se deberá indicar una breve descripción del conflicto, las generales de ley de las partes, las reclamaciones, el contrato o convenio del que emana o deriva su derecho a la competencia del centro, en la medida que -como en todo arbitraje- y este no es la excepción, se requiere el consentimiento de las partes para el sometimiento a este mecanismo de solución de conflictos.

El convenio señala que las partes podrán señalar si desean árbitro único o tribunal arbitral, pero si no lo deciden, este se compondrá de tres árbitros, cada parte elegirá a uno y entre estos elegirán al presidente del tribunal arbitral. En caso de no llegar a un acuerdo, la designación correrá a cuenta del Presidente del Consejo de administración del centro.

El Tribunal arbitral es el único competente para resolver o decidir sobre su propia competencia, sobre las excepciones de cualquier naturaleza (cosa juzgada, caducidad, incompetencia), sobre la inexistencia, nulidad o ineficacia del convenio arbitral o sobre la arbitrabilidad de la materia o sobre cualquier otro tema que busque impedir el conocimiento sobre el fondo del conflicto.

Sin duda el arbitraje depende en gran medida de los árbitros que conforman el tribunal arbitral. 
Como ocurre en todo proceso donde un tercero debe resolver un conflicto, este debe ser neutral frente a las partes, es decir, debe ser imparcial e independiente respecto de ellas, sus abogados, representantes, auditores y cualquier relación directa o indirecta que pueda poner en duda su actuación. La independencia tiene un carácter objetivo, como alguna relación de parentesco, dependencia laboral, financiera, amical, entre otros; mientras que la imparcialidad tiene que ver con un carácter subjetivo del árbitro, una predisposición, una inclinación, un prejuicio.

Es importante tener en consideración lo que señala el convenio del CIADI en la Regla 6 aplicable a los procedimientos de arbitraje, al señalar que cada árbitro una vez designado debe emitir una declaración cuyo texto es el siguiente:

"A mi leal saber y entender no hay razón alguna por la que no deba servir en el tribunal de arbitraje constituido por el Centro Internacional de Arreglo de Diferencias relativas a Inversiones con respecto a la diferencia entre .... y....".

"Me comprometo a mantener con carácter confidencial toda la información que llegue a mi conocimiento a consecuencia de mi participación en este proceso, así como del contenido de cualquier laudo que este tribunal dicte." "Juzgaré con equidad, de acuerdo con la ley aplicable y no aceptaré instrucción o compensación alguna de ninguna otra fuente con respecto al procedimiento, salvo según lo dispuesto en el Convenio sobre Arreglo de Diferencias relativas a Inversiones sobre Estados y Nacionales de otros Estados y en los Reglamentos y reglas adoptadas de conformidad con el mismo". "Adjunto una declaración sobre mi experiencia profesional, de negocios y otras relaciones (de haberlas) con las partes, tanto anteriores como actuales".

En toda declaración debe revelarse todas las circunstancias que puedan dar lugar a dudas sobre la imparcialidad o independencia del árbitro, tales como vinculación con las partes, con la controversia, con los abogados de las partes, con los demás co-árbitros, con otras personas implicadas en el arbitraje, para ello existen diversas fuentes de referencia para tomar en consideración sobre qué se debe revelar o cuándo no se puede aceptar el cargo de árbitro como las reglas de la International Bar Association o el 
Código de Buenas prácticas arbitrales del club español de arbitraje por mencionar algunas prácticas internacionales o las reglas éticas de la Cámara de Comercio de Lima por mencionar una referencia nacional.

Como es natural, si alguna de las partes considera que existe alguna duda justificada para dudar de la independencia o imparcialidad del árbitro deberá señalarlo, para lo cual tiene expedito su derecho de solicitar la recusación de un árbitro, el que será resuelto por los otros miembros del colegiado.

\section{PROCEDIMIENTO ARBITRAL}

La flexibilidad del procedimiento arbitral permite a las partes y en defecto de ellas, a los árbitros, fijar lo relativo a los plazos, reglas de presentación, actuación de pruebas entre otras. Esta libertad para fiar las reglas del procedimiento va de la mano con la autonomía de las partes para elegir las características de los árbitros, la libertad para elegir el tipo de arbitraje que desean, es decir si consideran más adecuado un arbitraje de conciencia o equidad o un arbitraje de derecho, siempre manteniendo el mismo derecho para ambas partes.

La finalidad de todo procedimiento es que las partes puedan exponer, sustentar sus alegaciones, ser escuchados, por los árbitros, para lo cual se podrán presentar memorias, contramemorias y las pruebas que consideren pertinentes, dentro de los plazos que serán determinados por el tribunal arbitral, previa coordinación con las partes.

La regla procesal aplicable a los procedimientos de arbitraje del Centro prescribe que, salvo pacto en contrario, el procedimiento comprenderá dos etapas distintas: una etapa dedicada a las actuaciones escritas y una segunda etapa dedicada a las actuaciones orales. Esta programación de las sesiones corresponderá fijarlas al tribunal arbitral.

Obviamente el Tribunal arbitral tiene la facultad de solicitar pruebas de oficio, e incluso de incorporar a los denominados "Amicus Curiae" o amigos del tribunal a efectos que expongan y permitan al tribunal tener todos los elementos de convicción para mejor resolver. 
El artículo 42 del Convenio prescribe que "El Tribunal decidirá la diferencia de acuerdo con las normas de derecho acordadas por las partes. A falta de acuerdo, el Tribunal aplicará la legislación del Estado que sea parte en la diferencia, incluyendo sus normas sobre Derecho Internacional Privado, y aquellas normas de Derecho Internacional que pudieran ser aplicables".

Es bueno recordar que la existencia del Derecho Internacional Privado tiene por objeto resolver conflictos que se presentan en una relación jurídica donde existen dos o más elementos extranjeros relevantes. En la medida que dos partes tengan sus domicilios en Estados diferentes y no hayan establecido el derecho que regulará dicha controversia, se deberá buscar el mejor Derecho y ello se efectuará mediante factores de conexión, que determinarán el derecho aplicable. Las normas que regularán el factor de conexión a aplicar serán las del Estado en controversia según lo prescrito en este artículo 42.

\section{LAUDO, REVISIÓN Y ANULACIÓN}

El resultado final de todo procedimiento es la emisión del laudo arbitral, es el objetivo de la designación de los árbitros, es la solución final del conflicto entre las partes y el cumplimento de la labor encomendada a los Árbitros.

El Laudo arbitral debe contener un resumen de los hechos, debe existir una motivación de los árbitros a la luz de las pruebas ofrecidas por las partes y actuadas en el desarrollo del proceso y debe existir una resolución sobre cada uno de los problema o controversias sometidas a la decisión de los árbitros, la cual tendrá el carácter de cosa juzgada.

Al igual que en el arbitraje comercial el procedimiento arbitral es instancia única y no cabe revisión sobre el fondo de la controversia. Sin embargo, hay una excepción -que no se encuentra regulada en nuestra legislación- denominada solicitud de Revisión del Laudo:

El artículo 51 del convenio señala "Cualquiera de las partes podrá pedir, mediante escrito dirigido al Secretario General la revisión del Laudo, 
fundada en el descubrimiento de algún hecho que hubiera podido influir, decisivamente en el laudo, y siempre que, al tiempo de dictarse el laudo, hubiera sido desconocido por el tribunal y por la otra parte que inste la revisión y que el desconocimiento de ésta no se deba a su propia negligencia”.

Tiene un plazo máximo de 90 días para solicitarse desde que se descubrió el hecho y un plazo de caducidad de 3 (tres) años de dictado el laudo y deberá ser resuelto por el mismo tribunal arbitral que dictó el laudo, en la medida de lo posible, de lo contrario se constituirá otro tribunal arbitral.

En cuanto a la Anulación del laudo, es una solicitud que busca salvaguardar la tutela procesal efectiva, se trata de cuestiones de forma, sin entrar a la motivación, ni a los criterios que tuvieron los árbitros al momento de laudar, se busca cautelar el debido proceso, básicamente lo que se busca es proteger a las partes del abuso de los árbitros, de la violación de algún derecho fundamental que haga inviable la ejecución del laudo.

Las causales de anulación de laudo son por los siguientes hechos:

i) una constitución incorrecta del tribunal arbitral;

ii) que el tribunal falló más allá de lo solicitado por las partes extralimitando sus facultades;

iii) que haya existido algún caso de corrupción sobre uno de los miembros del tribunal;

iv) que se haya quebrantado de manera grave una norma de procedimiento;

v) o que no exista motivación del laudo.

Estas causales de anulación deberán ser presentadas dentro de los 120 días siguientes de dictado el laudo, salvo la causal de corrupción que cuenta con un plazo de tres años para ser invocada desde la fecha de emitido el laudo. En estos casos se constituirá una comisión ad hoc integrada por tres personas seleccionadas de la lista de árbitros que cuenta el Centro. La comisión resolverá declarando fundada o infundada la solicitud de anulación de laudo arbitral, pudiendo incluso ordenar la suspensión provisional de la ejecución del laudo hasta emitir su decisión. 
En caso de declararse fundada la anulación, deberá integrarse un nuevo tribunal arbitral que revisará la controversia.

\section{RECONOCIMIENTO EJECUCIÓN DE LAUDO}

La idea de este convenio es que todo laudo arbitral dictado al amparo del Convenio CIADI se ejecute dentro de los territorios de los Estados miembros sin necesidad de llevar adelante un reconocimiento de sentencia o laudo arbitral emitido en el extranjero, conocido como el nombre de Exequatur.

En efecto, doctrinariamente, por un tema de territorialidad, cualquier sentencia judicial o laudo arbitral que es dictado en el exterior, requiere una revisión formal por parte del Estado en donde pretende ejecutarse dicha decisión.

Lo que se busca mediante el exequatur es que la decisión dictada en un territorio distinto al que se quiere ejecutar, previamente cumpla con un reconocimiento de determinadas seguridades y garantías jurídicas que el Estado receptor de la sentencia o laudo considera que deben cumplir todas aquellas decisiones que provengan de un país extranjero.

Entre los temas que el país receptor efectúa respecto de la decisión emitida en el exterior, es por ejemplo revisar si el tribunal extranjero que conoció el conflicto era competente para abocarse al conocimiento de dicho caso; si la materia no es de competencia exclusiva de los tribunales nacionales; si se cumplió con el debido proceso entendido como si se le dio un plazo suficiente para comparecer; si contó con abogado, si tuvo garantías para contradecir, ser escuchado; si la materia no viola asuntos de orden público internacional entre otros temas, que para el caso del Perú, se encuentran regulados en el artículo 2102 y siguientes del Código Civil. Digamos que se busca que cumpla con un test de legalidad.

Lo novedoso de este Convenio es que los países firmantes se comprometen a ejecutar las sentencias dictadas al amparo del tratado de Washington de 1965 sin necesidad de llevar adelante exequatur alguno, es decir que todo Estado contratante hará ejecutar dentro de su territorio las 
obligaciones impuestas en el Laudo como si se tratare de una sentencia firme dictada por un tribunal existente en dicho Estado.

\section{CONCLUSIONES}

1) El Convenio sobre Arreglo de Diferencias Relativas a Inversiones entre Estados y Nacionales de otros Estados (Convention of the Settlement of Investment disputes between States and National of other States) tiene por objeto la cooperación internacional para el desarrollo económico mediante la solución de conflictos que se presenten en materia de inversiones entre Estados y nacionales de otros Estados.

2) Se le conoce como convenio de Washington de 1965, siendo actualmente el referente para las soluciones en materia de inversión extranjera.

3) Bajo el auspicio del Banco Mundial el convenio crea el Centro Internacional de Arreglo de Diferencias relativas a Inversiones, el cual cuenta con un Consejo Administrativo compuesto por un representante de cada uno de los Estados contratantes.

4) El Consejo Administrativo se reúne cuando menos una vez por año y cuenta con un Secretario General además de varios secretarios adjuntos, siendo el Secretario General el representante legal y principal funcionario del Centro.

5) El Centro cuenta con un Reglamento Procesal para la Conciliación y el Arbitraje.

6) La jurisdicción del centro se aplica a inversiones entre un Estado contratante y nacionales de otro Estado contratante, entendiéndose como nacional de otro Estado a toda persona natural que tenga en la fecha en que las partes consintieron someter la controversia a conciliación o arbitraje, la nacionalidad de un Estado contratante distinto del Estado parte en la controversia. En ningún caso aplica para los nacionales del mismo Estado. 



\section{El asilo diplomático y el Caso Alan García

\author{
Diplomatic asylum and the Alan Garcia Case
}

Augusto Hernández Campos*

\section{RESUMEN}

El asilo diplomático o político constituye una institución relevante dentro del sistema universal de protección de Derechos Humanos y libertades fundamentales. Si bien se regula básicamente en América Latina, también existe cierta práctica en el resto de los países del mundo, aún cuando en principio no se le conceda reconocimiento jurídico. En este sentido, el asilo diplomático es una contribución que realiza América Latina, en el marco del

Doctor en Derecho y Ciencia Política, UNMSM (Universidad Nacional Mayor de San Marcos), summa cum laude, 2010. Profesor Principal de la Facultad de Derecho y Ciencia Política de la UNMSM. Catedrático de Derecho Internacional Público y Política Internacional. Profesor del Doctorado de Derecho de la UNMSM. Profesor del Doctorado y Postdoctorado del Centro de Altos Estudios Nacionales (CAEN), Lima. Profesor honorario del CAEN. Profesor de la Escuela de Relaciones Internacionales de la USIL (Universidad San Ignacio de Loyola). Miembro Titular de la Sociedad Peruana de Derecho Internacional. Miembro de la American Society of International Law y de la European Society of International Law. Es editor del Anuario Peruano de Derecho Internacional, de la Revista Peruana de Estudios del Asia-Pacifico y la Revista Peruana de Ciencia Política, de la UNMSM. Ha escrito libros de su especialidad.

Este ensayo surgió como parte del dictado del curso de Seminario de Derechos Humanos en el Doctorado de Derecho de la UNMSM.

Dedicado al TADI, Taller de Derecho Internacional, de la Facultad de Derecho y Ciencia Política de la UNMSM, que tuve el gusto de fundar en 1997, y que es el taller integrado por alumnos interesados en temas internacionales más antiguo y más prestigioso de esta facultad. Dedicado a mis alumnos de la Escuela de Relaciones Internacionales de la USIL (Universidad San Ignacio de Loyola). 
Derecho Internacional Americano, a los Derechos Humanos Internacionales y al Derecho Internacional en general. Si bien se concede el asilo diplomático por motivos de persecución política, en el caso de Alan García, Uruguay ha denegado este asilo pues no existían delitos políticos. La finalidad de este artículo será presentar algunos conceptos básicos sobre el asilo diplomático y el caso de Alan García, donde fue denegado dicho asilo por tratarse de investigación por delitos comunes.

Palabras clave: Derecho de Asilo Diplomático, Derecho Diplomático, Inmunidad de Jurisdicción, Inmunidad Diplomática.

\section{ABSTRACT}

Diplomatic or political asylum is a relevant institution within the universal system of protection of human rights and fundamental freedoms. Although it is basically regulated in Latin America, there is also some practice in the rest of the world, even if in principle it is not granted legal recognition. In this sense, diplomatic asylum is a contribution made by Latin America, within the framework of International American Law, to International Human Rights and to International Law in general. Although diplomatic asylum is granted on the grounds of political persecution, in the case of Alan Garcia, Uruguay has denied this asylum as there were no political crimes. The purpose of this article will be to introduce some basic concepts about diplomatic asylum and the case of Alan Garcia, where it was denied asylum because it was an investigation for common crimes.

Keywords: Law of Diplomatic Asylum, Diplomatic Law, Jurisdiction Immunity, Diplomatic Immunity.

\section{INTRODUCCIÓN}

El asilo diplomático o político constituye una institución relevante dentro del sistema universal de protección de Derechos Humanos y libertades fundamentales. Si bien se regula básicamente en América Latina, también 
existe cierta práctica en el resto de los países del mundo, aun cuando en principio no se le conceda reconocimiento jurídico. En este sentido, el asilo diplomático es una contribución que realiza América Latina, en el marco del Derecho Internacional Americano, a los Derechos Humanos Internacionales y al Derecho Internacional en general. Si bien se concede el asilo diplomático por motivos de persecución política, en el caso de Alan García, Uruguay y Costa Rica han denegado este asilo al expresidente peruano pues no existían delitos políticos.

La finalidad de este artículo será presentar algunos conceptos básicos sobre el asilo diplomático y el caso de Alan García, donde fue denegado dicho asilo por tratarse de investigación por delitos comunes.

Para cumplir con tal fin, se ha dividido el presente ensayo en varias partes. Se examinarán los siguientes temas: la definición de asilo diplomático, la evolución histórica, la diplomacia permanente, las teorías que fundamentan las inmunidades diplomáticas, la inviolabilidad del local de la misión, características del asilo diplomático, el asilo como regla latinoamericana, las fuentes del asilo diplomático, y el caso Alan García.

\section{DEFINICIÓN DE ASILO DIPLOMÁTICO O EXTRATERRITORIAL}

El asilo (del latín asylum, "santuario", y este del griego asylon, "refugio") es casi tan antiguo como la civilización. Aunque en su acepción contemporánea, el asilo tal como lo conocemos ahora surge al inicio de la era moderna.

Las expresiones Asilo Diplomático, Asilo Político y Asilo Extraterritorial se consideran como conceptos jurídicamente sinónimos. Esto se verifica en la Convención de Caracas sobre Asilo Diplomático de 1954, art. 1, cuando define el Asilo Diplomático como aquel "asilo otorgado en legaciones, navíos de guerra y campamentos o aeronaves militares". ${ }^{1}$

1 Convención sobre Asilo Diplomático de Caracas de 1954, art. 1. Según el mismo artículo, "legación es toda sede de mision diplomática". Ibid. 


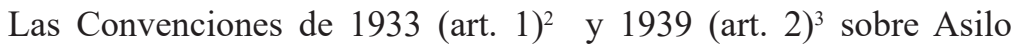
Político, definen al asilo político en el mismo sentido que la Convención de Asilo Diplomático de 1954, art. 1.

Se podría definir al asilo diplomático strictu sensu como el otorgamiento de refugio a una persona perseguida a causa de motivos políticos en el local de una embajada extranjera y que es concedida por el Estado acreditante dentro del territorio del Estado receptor que es el Estado de residencia o el Estado de nacionalidad del solicitante del asilo. En sentido estricto, el asilo diplomático sería una forma de asilo extra-territorial. ${ }^{4}$

En sentido amplio, el asilo extra-territorial incluiría no solo al concedido en instalaciones diplomáticas sino también en locales militares como campamentos o aviones militares, buques de guerra, incluso buques mercantes públicos, buques privados, y locales consulares. Empero, debido a que el asilo diplomático es la principal forma practicada de asilo extraterritorial, ambos términos se han fusionado y son sinónimos jurídicamente.

El asilo extraterritorial se puede definir como la protección que otorga un Estado a un extranjero fuera de su territorio en lugares que poseen inmunidad de jurisdicción (e.g., el local de su embajada), dichos lugares están en territorio extranjero.

La controversia del asilo extraterritorial estriba en que al ejercer su autoridad un Estado en el territorio de otro Estado se considera un quebrantamiento de la soberanía territorial.

Según nos recuerda Ronning, el asilo diplomático "se aplicará solo al refugio otorgado a personas en lugares que disfruten de inmunidad

\footnotetext{
2 Convención sobre Asilo Político de Montevideo de 1933, art. 1. El asilo político es el otorgado "en legaciones, naves de guerra, campamentos o aeronaves militares".

3 Tratado sobre Asilo Político y Refugiados de Montevideo de 1939. En el Capítulo I del Asilo Político, art. 2, define al Asilo Político como el que "solo puede concederse en las embajadas, legaciones, buques de guerra, campamentos o aeronaves militares". El asilo extraterritorial es concedido por un Estado fuera de su territorio en locales diplomáticos, en instalaciones dependientes del Estado en el extranjero como buques de guerra, campamentos o aviones militares. El asilo diplomático, strictu sensu, solo estaría relacionado con las instalaciones diplomáticas.
} 
diplomática de jurisdicción local. En otras palabras, es la protección otorgada al súbdito de un Estado dentro del territorio de ese Estado por el representante residente de un Estado extranjero." 5 De esta manera el enfoque se limita principalmente a la protección otorgada en legaciones y embajadas, pero "La práctica es extendida a menudo a los consulados y buques públicos (y en ocasiones privados) [...]". ${ }^{6}$

Felice Morgenstern, la excepcional académica de Cambridge y recordada profesora de derecho internacional, nos proporciona su definición:

"El termino "asilo "extraterritorial" es utilizado para indicar el asilo otorgado dentro del territorio del Estado donde se busca refugio. Se refiere al asilo en legaciones y consulados, y en buques de guerra y mercantes en los puertos del Estado del cual el individuo que busca refugio trata de escapar. A este respecto, difiere del asilo 'territorial', que es otorgado dentro del territorio del Estado que lo otorga. El asilo extraterritorial tiene lugar en perjuicio de la soberanía territorial del Estado donde se otorga. Por esto se restringe la jurisdicción del último sobre todos los individuos en su territorio, una jurisdicción que es, en virtud del derecho internacional, un atributo esencial de la soberanía del Estado. Por tanto, no es una práctica que pueda ser seguida a la ligera; su base legal debe ser establecida claramente."

El asilo diplomático, llamado también asilo político o asilo extraterritorial, existe cuando es otorgado en embajadas, consulados, aviones militares o buques de guerra en aguas extranjeras. Debido a que su práctica ha involucrado principalmente las instalaciones de la misión diplomática permanente, como las embajadas y legaciones, es conocido comúnmente como asilo diplomático.

$5 \quad$ La cursiva es del autor. Vid., Carroll Neale Ronning, Diplomatic Asylum: legal norms and political reality in Latin American relations (La Haya: Nijhoff, 1965), pp 7-8.

Op. cit.

Felice Morgenstern, “'Extra-territorial' Asylum”, British Yearbook of International Law, vol. 25 (1948), p. 236. 


\section{EVOLUCIÓN HISTÓRICA DEL ASILO}

El asilo es una institución que nace en la Antigüedad. El asilo es una protección que otorgaba un Estado a un extranjero perseguido (asilo territorial) o las iglesias oficiales ofrecían asilo religioso (santuario) a nacionales delincuentes comunes. El asilo religioso se considera como un antecedente del asilo diplomático. ${ }^{8}$ En diversas situaciones los Estados otorgaban asilo territorial a extranjeros perseguidos políticos como Aníbal que se refugió en Siria y Bitinia (durante las Guerras Púnicas), el ex-rey de Esparta, Demarato, quien se refugió en la corte del rey de Persia, Darío I (durante las Guerras Medicas), o Eneas hallando refugio en el Lacio (huyendo de Troya).

En el Medioevo, la Iglesia Católica Romana también podía otorgar santuario. "Los lugares sagrados, en virtud de su asociación con la divinidad, vinieron a ser considerados como inviolables [...]. En consecuencia, estos lugares otorgaban asilo a los perseguidos.", recordaba Sinha. ${ }^{9}$ El derecho de santuario o asilo religioso fue abolido durante la Reforma Protestante.

El asilo en su forma actual aparece cuando surge la sociedad moderna. El asilo se otorgaba en la sociedad premoderna a aquellos que cometían los delitos comunes, y después de manera sucesiva, en la sociedad moderna, a los que cometían delitos políticos.

Los delitos comunes pueden definirse, grosso modo, como aquellos que están comúnmente sancionados en los códigos penales de todos los países del mundo, como el robo, el chantaje, el homicidio, el estupro, entre otros. En cambio, los delitos políticos son aquellos que atentan contra la vigencia del sistema político-jurídico del Estado, por lo general estos últimos delitos suceden en los sistemas autoritarios.

\subsection{El asilo ratione personae: personas protegidas}

En la Edad Antigua y en el Medioevo, el asilo se otorgaba generalmente a personas que habían cometido los delitos comunes y no a aquellos considerados

\footnotetext{
8 Ambos tipos de asilo (religioso y diplomático) se otorgan en ciertos locales que gozaban de inmunidad frente a la jurisdicción territorial del Estado.

$9 \quad$ Prakash Sinha, Asylum and International Law (La Haya: Nijhoff, 1971), p. 5.
} 
los más peligrosos por los soberanos, los que cometían los llamados delitos políticos. Lo que sucede es que la represión de los delitos comunes se consideraba como materia de interés principalmente de los afectados y privados, y que la justicia penal no era una función esencial del Estado. Mientras, que el Estado debía centrarse en la represión de los delitos políticos considerados como los más peligrosos y que afectaban la autoridad del soberano.

En la Era Moderna, a partir de la Reforma Protestante se produce una inversión de los conceptos. Este cambio, en el Estado moderno, se debía a que los delitos comunes se consideraban iban en detrimento del interés público por lo que el ejercicio de la justicia penal se consideró como una función esencial del Estado. Además, se desarrolló la idea de la cooperación entre Estados para reprimir los delitos comunes mediante la extradición.

\subsection{EI asilo ratione loci: lugares de protección}

En la Antigüedad (Egipto, Grecia, Roma), y el Medioevo (Res Publicae Christiana), los lugares de asilo eran: (1) los territorios de los Estados extranjeros, y (2) los templos e iglesias (i.e. los lugares considerados sagrados de las iglesias oficiales). En el Medioevo, la Iglesia Católica en virtud de este asilo podía ofrecer santuario.

En la Era Moderna, con la secularización de la sociedad moderna, el asilo religioso perdió su significado. En adelante el asilo se daría solo en los territorios de los Estados (i.e., asilo territorial). La base del asilo territorial es el principio de soberanía.

\section{EVOLUCIÓN DE LA DIPLOMACIA Y LA DIPLOMACIA PERMANENTE}

\subsection{La diplomacia}

La diplomacia, como instrumento de relaciones entre los gobiernos de los Estados, ha existido desde los albores de la civilización y desde la aparición de los primeros Estados en Sumeria. La primera forma histórica de diplomacia fue la itinerante (diplomacia no permanente, especial, o ad hoc, aún vigente en la actualidad). 
El fundamento para la inmunidad de estas misiones diplomáticas itinerantes era la teoría del carácter representativo (o de la representación personal). Esta teoría es la más antigua de las que explican el status de los privilegios diplomáticos. Dado que los monarcas de los países dirigían las relaciones externas, su enviado era su representante personal, a veces referido como su alter ego. En consecuencia, conforme con el axioma latino par in parem non habet imperium, ${ }^{10}$ "él no podía de forma alguna estar sujeto a la autoridad del Estado al cual él ha sido enviado como el representante personal de un monarca soberano ante otro monarca soberano." ${ }^{11}$ En otras palabras la inmunidad de un agente diplomático surgía porque éste era considerado una extensión del gobernante que le enviaba. El representante era tratado como si el mismo soberano del Estado extranjero estuviera dirigiendo las negociaciones diplomáticas.

Esto se actualiza en el principio de inmunidad de los Estados soberanos, que señala que los Estados soberanos extranjeros no están sometidos a la jurisdicción de otros Estados debido a que justamente son soberanos (principio de soberanía), lo que incluye a sus representantes oficiales, como, por ejemplo, los jefes de Estados, de gobierno, o agentes diplomáticos.

\subsection{La diplomacia permanente}

Después, de forma sucesiva y yuxtapuesta, surgen las misiones diplomáticas permanentes, con el nacimiento del Estado moderno. Entonces, se planteó la teoría extraterritorial de Hugo Grocio como fundamento de la inmunidad diplomática al respecto. Las primeras misiones diplomáticas residentes o permanentes aparecen en la Italia renacentista del siglo XV.

Esta teoría quedó sustituida por la teoría de la necesidad funcional planteada por Cornelis van Bynkershoek y después por Emmerich De Vattel en el s. XVIII. A causa del rechazo de los Estados europeos, el

\footnotetext{
$10 \quad$ "No tiene autoridad un igual entre iguales".

11 Vid., Stanislaw Nahlik, "Development of Diplomatic Law: selected problems", en: Academia de Derecho Internacional. Recueil des Cours, T. 222, vol. 1990-III (Dordrecht: Nijhoff, 1991), p. 221.
} 
asilo diplomático o extraterritorial dejó de aplicarse casi completamente en Europa a inicios del siglo XIX, salvo en casos excepcionales como en disturbios políticos o guerra civiles. Como ya se indicó esta clase de asilo se consideró como perjudicial a la soberanía territorial del Estado. Asimismo, con el creciente abuso del franchise des quartiers, esta institución cayó más en el descrédito, sobre todo cuando Francia en 1693 aceptó finalmente su abolición. A fines del siglo XVII, comenzó a ser cuestionado el asilo diplomático en Europa, pues los Estados le consideraban como una amenaza a su soberanía. Al término del siglo XVIII, este derecho casi desapareció en Europa.

Sin embargo, a partir de la segunda década del siglo XIX el asilo diplomático fue aceptado en América Latina, especialmente después que accedieran a la independencia los veinte Estados latinoamericanos. Esto se debía especialmente a la alta inestabilidad política que tenían los países latinoamericanos con los golpes de Estado, revoluciones y guerras civiles. ${ }^{12}$ Desde los primeros tiempos de la vida republicana latinoamericana hasta mediados del siglo XIX, ya los viejos políticos derrotados acudían a las pocas y primeras legaciones o consulados extranjeros que habían sido acreditados. Poco a poco, con el paso de los años, los asilados fueron multiplicándose y las discusiones consiguientes convirtiéndose en más agudas y más jurídicas. ${ }^{13}$

El asilo diplomático surge cuando la Reforma Protestante, la Modernidad y la aparición del Estado moderno. El origen del asilo diplomático está estrechamente vinculado al establecimiento de misiones diplomáticas permanentes (particularmente relacionado al principio de la inviolabilidad de los locales de la misión diplomática). La diplomacia permanente (basada en misiones diplomáticas permanentes), como sabemos, es un fenómeno moderno vinculado al surgimiento del Estado moderno (después

12 Por ejemplo, en 1836, según el connotado historiador Jorge Basadre G., Perú tenia 7 presidentes de la república a la vez. Vid., Jorge Basadre G., Historia de la República del Perú 1822-1933, t. 2 (Lima: Universitaria, [1968]), p. 160.

13 Alejandro Deustua A., "Derecho de Asilo", Revista Peruana de Derecho Internacional, t. VII, no. 23-24 (enero-junio de 1947), p. 26. Deustua publicó un amplio y destacado trabajo sobre el Derecho de Asilo en la Revista Peruana de Derecho Internacional, en los números 23-24, 25-26 (julio-diciembre 1947), 27 (enero-abril 1948), y 28 (mayoagosto 1948). 
del Medioevo). El surgimiento de la diplomacia permanente condujo a la cuestión de la inviolabilidad de los locales de la misión diplomática. Con dichas misiones, también aparece la cuestión del asilo diplomático, i.e., el asilo otorgado en el local de la misión diplomática permanente.

\section{TEORÍAS QUE FUNDAMENTAN LAS INMUNIDADES DIPLOMÁTICAS}

Cuando surge la diplomacia permanente, a mediados del siglo $\mathrm{XV}$, surge la cuestión del otorgamiento de asilo en los locales de la misión diplomática permanente. Entonces, se examina la lógica que debe sustentar la inmunidad de la misión diplomática permanente, la cual permitirá o no el asilo diplomático, llamado también asilo extraterritorial.

Como ya se comentó antes, la primera teoría que fundamenta las inmunidades diplomáticas era la teoría representativa, y tuvo vigencia hasta fines del siglo XVIII. La segunda teoría, que es la extraterritorial, aparece con las primeras misiones diplomáticas residentes en el siglo XV y tuvo vigencia hasta inicios del siglo XX. La tercera, que es la funcional, surge en el siglo XVIII, pero se volverá la teoría suprema válida en el Derecho Diplomático en el siglo XX con la CVRD de $1961 .^{14}$

El asilo diplomático, que surge con las misiones diplomáticas permanentes en el siglo XV, tendrá vigencia hasta fines del siglo XVIII e inicios del siglo XIX, cuando desaparecerá por rechazo de los Estados europeos. Pero reaparecerá este tipo de asilo en América Latina en las primeras décadas del siglo XIX, y sigue vigente en el siglo XXI, sustentado mediante costumbre y tratados formulados por los Estados latinoamericanos.

\footnotetext{
$14 \quad C f$., Ismael Moreno Pino, La diplomacia: Aspectos teóricos y prácticos de su ejercicio profesional (México: Fondo de Cultura Económica, 2001), pp. 227-228. Para el embajador Moreno existían dos teorías adicionales: la teoría de Cecil Hurst y la del acuerdo tácito. Ibid.
} 


\subsection{La teoría extraterritorial}

El fundamento para la concesión del asilo en los locales de la misión diplomática era la teoría extraterritorial de las inmunidades diplomáticas, expuesta por Hugo Grocio en el S. XVII, que fue la primera que sustentó las inmunidades diplomáticas de las misiones diplomáticas permanentes. La teoría extraterritorial consideraba al edificio que ocupaba la embajada como territorio del Estado acreditante. Dado que, en virtud del principio de soberanía, un Estado podía otorgar asilo en su propio territorio, también podía otorgarlo en el edificio de su embajada, que era también territorio suyo. Es lo que el eminente académico polaco Stanislaw Nahlik llamó la "teoría de la inmunidad ilimitada de un enviado extranjero en el Estado receptor."15

Pero, esta teoría, como base del status privilegiado diplomático, entra pronto en cuestionamiento. Esto sucede cuando se considera que la concesión de asilo por una embajada extranjera representaría la aplicación de la jurisdicción extraterritorial de un Estado en detrimento de la soberanía y jurisdicción territorial del Estado receptor.

Además, los abusos cometidos por las embajadas en Europa en el marco de esta teoría (así como los atropellos efectuados por las embajadas de los Estados europeos en Oriente Medio y el Imperio Otomano con las "capitulaciones", y en China mediante las "concesiones") y al amparo de esta inmunidad, sobre todo al extender esta inmunidad a todo el barrio donde está la embajada (ius quarteriorum, "ley del barrio", conocido también como franchise $d u$ quartier, que representan el mayor desprestigio para esta inmunidad, y fue una prepotencia del asilo diplomático europeo), ${ }^{16}$ se convirtieron en descrédito para esta inmunidad, pues las embajadas permitían que delincuentes comunes escaparan a la justicia (y que los extranjeros europeos en los países asiáticos se colocaran por encima de la jurisdicción territorial).

De esta manera, a inicios del siglo XIX, esta clase de asilo fue abandonada por los Estados europeos. Mientras, por otra parte, la teoría

15 Stanislaw Nahlik, op. cit., p. 223.

16 Debido a que muchas residencias diplomáticas extranjeras eran a menudo agrupadas en vecindarios, barrios o distritos, el ius quarteriorum creaba asi un área interna sujeto a la jurisdicción extraterritorial del Estado extranjero (o Estados extranjeros). 
extraterritorial sería sustituida por la teoría funcional a mediados del siglo XX (planteada en el siglo XVIII por vez primera).

\subsection{La teoría de la necesidad funcional}

Cuando la teoría extraterritorial fue sustituida por la teoría de la necesidad funcional, se abandonó el fundamento jurídico del asilo diplomático o extraterritorial a mediados del siglo $\mathrm{XX}$, y de este modo la regla jurídica que permitiría este asilo en adelante sería el principio de inviolabilidad del local de la misión diplomática extranjera en el marco de la teoría funcional.

En el siglo XVIII, la teoría funcional fue expuesta primero por Cornelis van Bynkershoek, y posteriormente por Emmerich De Vattel. Pero, la teoría funcional solo se volvió la teoría imperante de forma definitiva en el Derecho Diplomático con la Convención de Viena de Relaciones Diplomáticas (CVRD) de 1961.

Por tanto, con esta moderna teoría se reconoce la supremacía del principio de soberanía territorial. La soberanía sobre un territorio confiere al soberano el derecho de excluir el ejercicio de jurisdicción sobre aquel territorio por otro soberano. De este modo, se descarta el asilo diplomático o extraterritorial, pues se consideraba que este lesionaba dicha soberanía. El territorio donde se localiza la sede de la misión diplomática extranjera se considera como territorio del Estado receptor.

Esta teoría indica que un enviado debe cumplir funciones oficiales en territorio extranjero en interés de ambos Estados. Por tanto, en el Estado receptor, al enviado se le debe otorgar privilegios e inmunidades necesarios para el cumplimiento de sus funciones. Es lo que Nahlik denominó como "la teoría de la inmunidad limitada de un enviado extranjero." 17

El asilo diplomático no es regla de Derecho Internacional general y no figura en la Convención de Viena de Relaciones Diplomáticas (CVRD) de 1961. La inviolabilidad del local, que es una inmunidad básica sustentada,

$17 \quad$ Nahlik, op. cit. 
no en la teoría de la extraterritorialidad sino, en la necesidad de las funciones, permite el asilo diplomático.

\section{LA INVIOLABILIDAD DEL LOCAL DE LA MISIÓN DIPLOMÁTICA SEGÚN LA CVDR}

La inviolabilidad de los locales de la misión diplomática constituye el privilegio más importante (de los privilegios diplomáticos). El art. 22, par. 1, de la CVRD, dice: "Las instalaciones de la misión serán inviolables. Los agentes del Estado receptor no pueden entrar en ellas, excepto con el consentimiento del jefe de misión". Es la clásica franchise d'hôtel (del francés, "inviolabilidad del local", i.e. de las instalaciones de la embajada y de la residencia privada del embajador), que nos recuerda Javier Pérez de Cuéllar. ${ }^{18}$

\section{EL CASO DE JULIAN ASSANGE}

En el caso de Julian Assange se planteó el asilo diplomático, cuando en Londres, el 16 de agosto del 2012, Ecuador anunció que otorgaría refugio a Julian Assange en el local de su embajada. Assange había entrado allí el 19 de junio anterior. Sin embargo, el Reino Unido no reconoce el asilo diplomático. Pero, las fuerzas policiales inglesas no entran en la embajada ecuatoriana debido a la inviolabilidad del local de la misma.

Cuando el nuevo gobierno de Lenin Moreno asumió el mandato en mayo del 2017 la situación cambió radicalmente, pues el nuevo presidente invitó a las fuerzas del orden británicas a entrar en el local de la misión diplomática ecuatoriana el 11 de abril del 2019, fecha en que arrestaron a Assange en una de las habitaciones de la embajada. Así, terminaron 7 años de crisis en las relaciones Ecuador-Reino Unido, por la permanencia de

18 Javier Pérez de Cuéllar, Manual de derecho diplomático (México: Fondo de Cultura Económica, 1997), p. 89. 
Assange dentro del local de la embajada ecuatoriana. Este es uno de los muy escasos casos en que el Estado acreditante levanta la inmunidad de su propia embajada frente al Estado receptor.

\section{ASILO DIPLOMÁTICO COMO REGLA LATINOAMERICANA}

Como bien nos apunta Francis Deák, "La doctrina del asilo diplomático no ha logrado una aceptación general en el derecho internacional." ${ }^{19} Y$ agrega: Durante el siglo XIX, "la práctica de conceder este asilo quedo mayormente limitada a América Latina y fue vista con malos ojos por Estados Unidos y la mayoría de los países europeos." ${ }^{20}$

La única región en donde el asilo diplomático se mantiene como regla jurídica internacional es América Latina. El asilo diplomático sucede, principalmente, cuando el individuo busca protección en el local de una misión diplomática, siendo el caso más célebre el caso del Asilo de Haya de la Torre en 1949-1954.

Como ya se indicó, este tipo de asilo no es regla del DI general, ni la contempla la CVRD de 1961. La única concesión de esta Convención fue el art. 41, par. 3, para permitir el uso del asilo diplomático por los Estados latinoamericanos. Javier Perez de Cuellar nos remarca su exclusión de la CVRD (Convención de Viena de Relaciones Diplomáticas):

"Aunque vinculado a la inviolabilidad de los locales de las Misiones diplomáticas, este derecho no es considerado una institución de Derecho Diplomático y, en consecuencia, la Conferencia de Viena [de Relaciones Diplomáticas] de 1961 decidió no ocuparse de esa materia en su Proyecto de Convención." ${ }^{21}$

19 Vid., Francis Deák, "Órganos del Estado en sus relaciones exteriores: inmunidades y privilegios del Estado y de sus órganos”, en: Max Sorensen (ed.), Manual de Derecho Internacional Público (México: Fondo de Cultura Económica, 1985), p. 399.

$20 \quad$ Ibid.

21 Javier Pérez de Cuéllar, Manual de derecho diplomático (México: Fondo de Cultura Económica, 1997), p. 118. 
A pesar que se considera que el asilo extraterritorial no tiene validez frente a la jurisdicción territorial, porque quebranta este principio de jurisdicción fundamental, en América Latina alcanzó la categoría de regla. Además, es un principio bien establecido de derecho internacional que los Estados pueden limitar su propia soberanía mediante tratados internacionales. Así, los Estados latinoamericanos han suscrito tratados diversos relacionados con el asilo diplomático.

La causa por la que en América Latina el asilo se ha mantenido es fundamentalmente por el hecho que los sistemas políticos estatales de la región han sido sumamente inestables. Las numerosas revoluciones y golpes de Estado en esta región convertían a los gobiernos de hoy en los perseguidos de mañana, de esta manera serían los próximos en buscar asilo.

\section{El asilo diplomático fuera de América Latina}

Como se comentó antes, el asilo diplomático dejó de observarse en Europa, especialmente a partir de inicios del siglo XIX. En adelante, la concesión de lo que podría ser asilo diplomático, cuando se efectuara, se basará en consideraciones humanitarias extrajurídicas, y al no existir una práctica uniforme, no existe una costumbre respectiva. En el siglo $\mathrm{XX}$, tuvo reapariciones en algunas ocasiones como la Guerra Civil Española, en ciertas situaciones de la Segunda Guerra Mundial ${ }^{22}$ y la Guerra Fría. Javier Pérez de Cuéllar, el prestigioso antiguo secretariogeneral de la ONU, nos recuerda que "El breve retorno del asilo en los casos mencionados adoptó en Europa la forma de refugio temporal por razones humanitarias y se valió como fundamentos de la protección de los derechos humanos y del respeto a la inviolabilidad de las Misiones por el Estado receptor." 23

22 Como sucedió con el asilo otorgado a judíos por misiones diplomáticas de Estados neutrales en Budapest. Fue realizado por agentes diplomáticos como Raoul Wallenberg de Suecia, Carl Lutz de Suiza, Angel Sanz-Briz de España, Carlos S. Garrido de Portugal, Angelo Rotta de la Santa Sede, y Friedrich Born del CICR), durante el holocausto perpetrado por el régimen de Ferenc Szalasi, primer ministro de Hungría y jefe de los nazis húngaros de la Cruz Flechada. Irlanda no tenia relaciones diplomaticas con este pais centroeuropeo. 
Empero, algunos países, pese a que se oponen a darle la categoría de regla, debido a ciertas circunstancias especiales (básicamente por cuestiones humanitarias), la practican en diversas ocasiones. Aquí se pueden citar los casos practicados por EEUU en el célebre asilo del Cardenal Josef Mindszenty, primado de la iglesia católica húngara, en Budapest en 19561971, y en el caso del líder de las manifestaciones de la plaza de Tiananmen, Fang Lizhi, en Beijing en 1989-1990, entre otros.

\section{FUENTES DEL DERECHO DE ASILO DIPLOMÁTICO}

El asilo diplomático sólo es reconocido como tal en el Derecho Internacional americano (i.e., latinoamericano). Si bien el reconocimiento del principio de otorgar asilo político se desarrolló en una práctica latinoamericana formando una costumbre regional, fue también reconocida en tratados. Entre las normas que regulan este tipo de asilo están las que se consignan a continuación.

El primer tratado bilateral suscrito en el hemisferio occidental que trataba el tema de regulación del asilo para perseguidos políticos fue el Tratado de No Extradición por Delitos Políticos entre México y Colombia de 1823.

\subsection{Las reglas de 1867,1898 y 1922}

La práctica del asilo diplomático revivió en América Latina a poco de producida la emancipación en la década de 1820, y adquirió al cabo de unas tres o cuatro décadas de aplicación el carácter de una institución propia del Derecho Internacional americano, según observó Llanos Mansilla. ${ }^{24}$ Las arbitrariedades y divergencias que la práctica descontrolada del asilo diplomático producía (como había sucedido en Europa antes), en un principio condujeron a los Estados latinoamericanos desde el inicio a tratar de regularlo (no a prohibirlo como sucedió en el Viejo Continente).

$24 \quad$ Vid., Hugo Llanos Mansilla, Teoría y práctica del derecho internacional público, t. III, La persona humana (Santiago: Editorial Jurídica, 1983), p. 413. 
Así, se decidió restringir su aplicación exclusivamente al caso de los perseguidos políticos. Este esfuerzo reglamentador prosiguió, "siempre con la mira de evitar que la aplicación indiscriminada del asilo llevara al descredito y la quiebra de la institución." 25

Las Reglas que se elaboraron en las Conferencias del Cuerpo Diplomático de Lima de 1867, de La Paz de 1898, y deAsunción de 1922, eran reglas que establecían pautas para la concesión de asilo diplomático, y fueron formuladas por representantes diplomáticos de Estados latinoamericanos y de otros Estados acreditados ante los gobiernos de América Latina.

En 1867, el ministro de relaciones exteriores del Perú, con la asistencia de los agentes diplomáticos acreditados ante el gobierno peruano, convocó una conferencia en Lima con el objetivo de determinar de manera uniforme el ámbito y procedimiento para el asilo diplomático. Se contó con la oposición de ciertos delegados.

Después de la conferencia de Lima de 1867, la idea de una regulación internacional del asilo diplomático fue retomada por el Tratado de Derecho Penal Internacional de enero de 1889 adoptado por el Primer Congreso Sudamericano de Derecho Internacional Privado realizado en Montevideo. También, se revisó el tema en el proyecto de Código de Derecho Internacional Público de 1911 de Epitacio Pessoa. Según Sinha, estos documentos "reconocían el asilo diplomático de delincuentes políticos como un derecho o una tolerancia aceptados por usos, convenciones, o leyes" de Estados latinoamericanos. ${ }^{26}$ Dicho asilo podía otorgarse en legaciones, buques de guerra, campos militares, y los aviones militares (que fueron añadidos con la Convención de 1928, art. 1). Los buques mercantes fueron incluidos en esta clase de asilo por el Tratado General de Paz y Amistad entre las Republicas Centroamericanas del 20 de diciembre de 1907 (art. 10).

\subsection{El tratado de derecho penal internacional de $\mathbf{1 8 8 9}$}

El primer tratado multilateral subregional (sudamericano) que expresamente reconoce el asilo diplomático fue el Tratado sobre Derecho

\footnotetext{
25 Loc. cit.

26 Vid., Prakash Sinha, Asylum and International Law (La Haya: Nijhoff, 1971), p. 28.
} 
Penal Internacional de Montevideo de 1889. La parte relevante de este Tratado es el art. 17, que dice:

"El reo de delitos comunes que se asilase en una Legación deberá ser entregado por el jefe de ella a las autoridades locales, previa gestión del Ministerio de Relaciones Exteriores, cuando no lo efectuase espontáneamente.

Dicho asilo será respetado con relación a los perseguidos por delitos políticos, pero el jefe de la Legación está obligado a poner inmediatamente el hecho en conocimiento del Gobierno del Estado ante el cual está acreditado, quien podrá exigir que el perseguido sea puesto fuera del territorio nacional dentro del más breve plazo posible.

El jefe de la Legación podrá exigir, a su vez, las garantías necesarias para que el refugiado salga del territorio nacional respetándose la inviolabilidad de su persona. El mismo principio se observará con respecto a los asilados en los buques de guerra surtos en aguas territoriales. ${ }^{27}$

Este tratado tuvo vigencia para cinco Estados sudamericanos: Argentina, Bolivia, Paraguay, Perú y Uruguay.

Otro antecedente lo constituyó el Acuerdo bolivariano sobre extradición de Caracas de 1911 entre Venezuela, Colombia, Ecuador, Perú, y Bolivia. Su artículo 18 señalaba que "se reconoce la institución del asilo conforme a los principios del derecho internacional".

\subsection{Las Convenciones de 1928, 1933 y 1939}

Los 3 primeros tratados específicos sobre asilo diplomático son: la Convención sobre Asilo de La Habana de 1928, la Convención sobre Asilo Político de Montevideo de 1933, y el Tratado sobre Asilo Político y Refugiados de Montevideo de 1939 (los casos de asilo de la Guerra Civil Española contribuyeron a formular este último tratado). En el marco panamericano, se adoptaron dos tratados relativos al asilo: el de La Habana en 1928 y el de Montevideo en 1933.

27 Tratado de Derecho Penal Internacional de Montevideo, art. 17. 
La existencia y reconocimiento del asilo diplomático fue confirmado por la Convención sobre Asilo de La Habana de 1928. Esta convención codificó los principios del asilo diplomático. Prohibía el asilo diplomático a delincuentes comunes, válido solo a delincuentes políticos. Durante la VI Conferencia Internacional Americana se adoptó la Convención sobre Asilo de La Habana de 1928. El art. 1 de la Convención de La Habana prohíbe el asilo para los delincuentes comunes y sí lo permite para los delincuentes políticos. Se establece que los primeros deberán ser entregados a las autoridades territoriales, mientras que los delincuentes políticos no pueden ser entregados. A juicio de Monroy, este principio lo reconoció la Corte Internacional de Justicia en su sentencia del 13 de junio de 1951 en el caso de Asilo de Haya de la Torre, donde dijo que la entrega de delincuentes políticos no puede tener lugar ni en el caso que el asilo hubiere sido concedido de forma irregular. ${ }^{28}$ Recibió la ratificación de 15 Estados: Brasil, Colombia, Costa Rica, Cuba, Ecuador, El Salvador, Guatemala, Haití, Honduras, México, Nicaragua, Panamá, Paraguay, Perú, y Uruguay.

Durante la VII Conferencia Internacional Americana se adoptó la Convención sobre Asilo Político de Montevideo de 1933. Su contribución más importante radica en el art. 2, que establece que la calificación del delito político le corresponde al Estado que presta el asilo, es decir, que consagra el sistema de la calificación unilateral del Estado asilante. Nos recuerda Egidio Reale, que la Convención de 1933 “contiene la estipulación conocida bajo el nombre de cláusula belga que excluye de la noción de crimen político el atentado cometido contra la persona del jefe de Estado o de un miembro de su familia." ${ }^{29}$ Ha recibido la ratificación o adhesión de 16 Estados: Brasil, Chile, Colombia, Costa Rica, Cuba, Ecuador, El Salvador, Guatemala, Haití, Honduras, México, Nicaragua, Panamá, Paraguay, Perú (la ratificó en 1960), y República Dominicana.

En el ámbito subregional del II Congreso Sudamericano de Derecho Internacional Privado celebrado en Montevideo se aprobó el Tratado sobre

28 Vid., Marco Monroy Cabra, Derecho Internacional Público (Bogotá: Temis, 2011), p. 685.

${ }_{29} C f$., Egidio Reale, "Droit d'Asile", en: Academia de Derecho Internacional, Recueil des Cours, 1938, t. 63, p. 555. 
Asilo Político y Refugiados de Montevideo de 1939, que fue suscrito por Argentina, Bolivia, Chile, Paraguay, Perú y Uruguay. Solo fue ratificado por Paraguay y Uruguay.

\subsection{Caso de asilo de 1950}

La jurisprudencia de la CIJ en Caso del Derecho de Asilo de 1950 (Perú vs. Colombia) también trata asuntos relativos con el asilo diplomático. La sentencia de la CIJ del 20 de noviembre de 1950, la del 27 de noviembre de 1950, y la del 13 de junio de 1951 en el caso de Asilo suscitaron un amplio descontento en América Latina.

El eximio jurista uruguayo Eduardo Jiménez de Aréchaga considera que la "Convención sobre Asilo Diplomático [de 1954] constituyó la réplica que dio la Organización de Estados Americanos al erróneo fallo que dio la Corte Internacional de Justicia en el Caso Haya de la Torre en 1950. ${ }^{30}$ En el mismo sentido, el embajador Rubens Ferreira de Mello afirmó que la Corte Internacional de Justicia "demostrando un profundo desconocimiento de la institución del asilo en América, pronuncio dos sentencias al respecto [...]". ${ }^{31}$ De igual manera, nos subraya la misma opinión el embajador Geraldo Eulalio do Nascimento e Silva que dice: "La decisión de la Corte fue criticada severamente, especialmente en América Latina que evitó, después de aquella sentencia, recurrir a la Corte hasta 1984 cuando Nicaragua presentó una demanda contra los Estados Unidos." 32

En opinión de Julio Barberis el "caso de asilo diplomático más famoso en el derecho internacional es indudablemente el de Víctor Raúl Haya de la Torre, que dio lugar a tres decisiones de la Corte Internacional de Justicia. Sin embargo, el estudio de estas decisiones no se recomienda

$30 \quad$ Eduardo Jiménez de Aréchaga et al., Derecho Internacional Público, t. 2 (Montevideo: Fundación de Cultura Universitaria, 2008), p. 427.

31 Rubens Ferreira de Mello, Dicionário de Direito Internacional Publico (Rio de Janeiro: Iguassu, 1962), p. 209.

32 Vid., Geraldo E. do Nascimento e Silva, "Diplomatic and Consular Relations", en: M. Bedjaoui (ed.), International Law: Achievements and Prospects (París/Londres/ Boston/Dordrecht: Nijhoff, 1991), p. 442. 
como el mejor medio de alcanzar una idea precisa de la naturaleza del asilo diplomático." 33

\subsection{La Convención de Asilo Diplomático de Caracas de 1954}

Finalmente, durante la Décima Conferencia Interamericana, se suscribió la Convención sobre Asilo Diplomático de Caracas de 1954. Este último tratado codifica la costumbre regional relativa al asilo diplomático y representa la culminación del desarrollo del Derecho de Asilo Diplomático latinoamericano. Recoge también la experiencia latinoamericana frente al caso de Asilo de Haya de la Torre. Seguidamente consignamos las principales disposiciones de esta Convención.

El art. 1, como ya se indicó antes, establece los lugares donde se puede otorgar el asilo diplomático como la sede de la mision diplomática (incluía también a las residencias privadas de los jefes de misión y en los lugares habilitados para ese efecto cuando el número de asilados exceda la capacidad normal de los lugares de refugio), los campamentos militares, buques de guerra, y aviones militares.

También, indica que solo se otorgará asilo a las personas perseguidas por delitos políticos, no por delitos comunes.

El art. 2, afirma que la concesión o no de asilo es una facultad soberana del Estado. No esta obligado a concederlo, ni tiene por qué fundamentar por qué lo niega, si fuera el caso. Ergo, "el individuo no podrá reclamar si un agente diplomático se niega a asilarlo." ${ }^{34}$

El art. 4, es una contribución extremadamente relevante, pues establece que: "Corresponde al Estado asilante la calificación de la naturaleza del delito [...]". Esta calificación unilateral permite así la supervivencia de la institución del asilo.

33 Julio Barberis, "Asylum, Diplomatic", en: R. Bernhardt (ed.). Encyclopedia of Public International Law, vol. I (Amsterdam-Londres-Nueva York: North Holland, 1992), p. 282.

34 Enrique Gaviria Lievano, Derecho Internacional Público (Bogotá: Temis, 2005), p. 317. 
El art. 5, establece que el asilo solo procede en casos de urgencia (como un riesgo de linchamiento, detención ilegal, entre otros), cuya calificación corresponde al Estado asilante. Asimismo, procede por el tiempo indispensable para permitir al asilado salir al extranjero.

El art. 9, el Estado asilante recibirá los informes del Estado territorial sobre el caso, "pero será respetada su determinación de continuar el asilo o exigir el salvoconducto para el perseguido".

El art. 12, afirma que "Otorgado el asilo, el Estado asilante puede pedir la salida del asilado para territorio extranjero, y el Estado territorial está obligado a dar [...] las garantías necesarias [...]".

El art. 17, indica que una vez realizada la salida del asilado, "el Estado asilante no está obligado a radicarlo en su territorio, pero no podrá devolverlo a su país de origen sino cuando concurra voluntad expresa del asilado".

A juicio de opiniones de la doctrina colombiana, la Convención de 1954 superó en mucho las disposiciones de las convenciones anteriores. Para "Colombia [la Convencion de 1954] representó un triunfo diplomático, pues tres años después de haberse proferido el fallo de la Corte Internacional de Justicia en el caso de Haya de la Torre venían a incluirse disposiciones antes rechazadas por el mas alto tribunal de justicia." ${ }^{35}$

Esta Convención de Asilo Diplomático de 1954 tiene vigencia en la actualidad y posee 14 Estados parte. Como nos remarca Eduardo Jiménez de Aréchaga, "hay dos países que han aceptado en la práctica el ejercicio del asilo en su territorio, a pesar de que no están ligados por ninguna obligación convencional para hacerlo, que son España [...] y Portugal."’36

\subsection{El Asilo Diplomático y la CVRD de 1961}

Por otro lado, el embajador mexicano Ismael Moreno Pino nos señala muy acertadamente sobre las funciones del agente diplomático "que

$35 \quad$ E. Gaviria Lievano, op. cit., p. 316.

36 Vid., Eduardo Jiménez de Aréchaga, Derecho Internacional Público, t. 2 (Montevideo:

Fundación de Cultura Universitaria, 2008), p. 415. 
ofrecer asilo no es permitido, ya que ello significa una injerencia del agente diplomático en los asuntos propios del Estado territorial." ${ }^{37}$ El solicitante de asilo debe acudir motu proprio a la sede de la misión diplomática.

Mientras que ningún artículo de la CVRD (Convención de Viena de Relaciones Diplomáticas) de 1961 trata de forma expresa y específica con el asilo diplomático, la Convención incluye dos normas que tienen un efecto directo en esta práctica, nos recuerda Paul Behrens, profesor de la Universidad de Edimburgo. ${ }^{38}$ La primera es la prohibición de interferencia en asuntos internos que se encuentra regulada en el art. 41, par. 1, que dice:

"1. Sin perjuicio de sus privilegios e inmunidades, todas las personas que gocen de esos privilegios e inmunidades deberán respetar las leyes y reglamentos del Estado receptor. También están obligados a no inmiscuirse en los asuntos internos de ese Estado." 39

La obligación de no interferencia por parte de los miembros de la misión diplomática se complementa con una segunda norma que podría aplicarse para casos de asilo diplomático. El art. 41, par. 3, de la CVRD (Convención de Viena de Relaciones Diplomáticas) específicamente examina el uso de las instalaciones de la misión e indica que deben utilizarse según la CVRD y cualquier otro tratado específico vigente:

"3. Los locales de la misión no deben ser utilizados de manera incompatible con las funciones de la misión tal como están enunciadas en la presente Convención, en otras normas del derecho internacional general o en los acuerdos particulares que estén en vigor entre el Estado acreditante y el Estado receptor." ${ }^{40}$

Por tanto, los locales de la misión deberán ser utilizados de conformidad con la CVRD, con otras normas de DI general o con otros

\footnotetext{
37 Ismael Moreno Pino, La diplomacia: aspectos teóricos y prácticos de su ejercicio profesional (México: Fondo de Cultura Económica, 2001), p. 302.

38 Paul Behrens, "The Law of Diplomatic Asylum: A contextual approach", Michigan Journal of International Law, vol. 35 (invierno 2014), p. 325.

39 La cursiva es nuestra. CVRD, art. 41, par. 1.

40 La cursiva es nuestra. CVRD, art. 41, par. 3.
} 
tratados específicos, esto ultimo significaría la inclusión de la Convención de Caracas de 1954, lo que permitiría el asilo diplomático. ${ }^{41}$

\section{EL CASO ALAN GARCÍA (17 DE NOVIEMBRE - 3 DE DICIEMBRE 2018)}

\subsection{La investigación a García y su búsqueda de asilo}

El domingo 18 de noviembre del 2018, Uruguay anunció la entrada de Alan García al local de la residencia privada del embajador de Uruguay en Lima la noche del sábado 17 solicitando asilo diplomático. Uruguay y Perú son partes de la Convención de Caracas de Asilo Diplomático de $1954 .{ }^{42}$

El mismo sábado 17, unas horas antes, el Poder Judicial había ordenado 18 meses de impedimento de salida del país de García y después que este último dijera que no saldría del Perú. El Poder Judicial investigaba a García por delito de corrupción, por una presunta colusión agravada y lavado de activos en el caso Odebrecht en Perú.

Para todos los efectos prácticos, la residencia privada del funcionario diplomático goza de los mismos privilegios e inmunidades que el local oficial de la embajada (CVRD, art. 30, par. 1).

García era investigado por el fiscal contra el lavado de activos, José Domingo Pérez, por presuntamente haber recibido un pago de Odebrecht por US\$ 100.000 dólares por dictar una conferencia en Brasil, a través de un intermediario. La Fiscalía peruana había solicitado 48 horas antes esta medida de restricción (18 meses de impedimento de salida del país) contra García, en el marco de las investigaciones que se siguen en su contra por presuntamente haber favorecido a la empresa Odebrecht en la licitación del Metro 1 de Lima.

El juez Juan Carlos Sánchez, del Segundo Juzgado de Investigación Preparatoria Anticorrupción, afirmó el sábado 17 que "existen suficientes

\footnotetext{
$41 \quad$ Behrens, op. cit., p. 327.

42 Vid., tabla del Anexo 1, ut infra.
} 
elementos de convicción" y declaró fundada la medida de restricción pedida por la fiscalía. Como consecuencia de esta medida judicial, García decidió escapar a la investigación y buscar refugio en la residencia del embajador de Uruguay.

Por otro lado, la declaración política de Alan García emitida el 21 de noviembre por intermedio de su abogado (una carta dirigida a la opinion pública donde insistío en ser víctima de una persecución política) sería una violación del art. 18 de la Convención de Caracas de 1954. Así, lo confirmaron el ex-canciller del Perú, Eduardo Ferrero Costa, y el internacionalista, Juan Velit Granda, en entrevista al diario El Comercio el 22 de noviembre del 2018.

\subsection{Negación de asilo por delitos comunes}

Conforme con la Convención de Caracas de 1954, se otorga asilo por delitos políticos y no por delitos comunes. Determinando si la investigación o procesamiento por delito de corrupción es delito político o común, se podrá determinar si puede recibir asilo o no.

García era investigado por el poder judicial por corrupción. Dado que la corrupción no es un delito político sino común, Uruguay negó el asilo.

En la hipótesis que Uruguay hubiera otorgado asilo, esto hubiera significado un golpe nefasto contra la lucha anti-corrupción. Esto significaría que en el futuro el Poder Judicial de Perú y de otros países latinoamericanos no podrían investigar y procesar a ex-jefes de Estado (y otros ex funcionarios de alto nivel) por corrupción, y si lo hiciera los procesados o investigados podrían recibir refugio en Uruguay porque son perseguidos por "delitos politicos". En esta situación, si Uruguay hubiera otorgado asilo a García, pese a que se le investiga por cometer un delito común y no uno político, Perú hubiera podido solicitar a la CIJ una interpretación de la expresión "delitos políticos" del art. 1 de la Convención de 1954, y si Uruguay en este sentido habría cumplido o no con la Convención de Caracas.

\subsection{Uruguay rechaza conceder asilo a García}

El lunes 3 de diciembre del 2018, el Gobierno de Uruguay anunció que no le concedería el asilo diplomático a Alan García. El presidente 
de Uruguay, Tabaré Vázquez, indicó que el caso de Garcia "no es una persecución política". Por lo que así García terminó una estadía de 16 días en la residencia del embajador uruguayo, y se invitó al nacional peruano a retirarse de la residencia del embajador, lo que se hizo, horas antes, a las 8 am de este mismo dia. ${ }^{43}$

Ya antes, el 18 de enero del 2002, Uruguay había negado asilo a dos ministros del régimen fuji-montesinista, Carlos Boloña y Alberto Bustamante, quienes alegaban persecución política, pero que enfrentaban en realidad cargos por delito de corrupción y vinculación con Vladimiro Montesinos.

\subsection{Costa Rica rechaza conceder asilo a García}

El presidente de Costa Rica, Carlos Alvarado, indicó (el mismo día 3 de diciembre del 2018 en entrevista concedida al periodista Camilo Egaña de CNN en español) que García había hecho la solicitud informal de asilo por medio de un emisario el jueves 29 de noviembre ante el encargado de negocios de la embajada de Costa Rica en Lima.

Pero, la respuesta del gobierno costarricense fue negativa. Analizando la posibilidad de otorgarle asilo a Alan García, Alvarado respondió a la pregunta formulada por Camilo Egaña:

"No. En este caso, sobre una primera comunicación, se hizo ver que la anuencia no está ahí presente en este momento para avanzar con esa condición, por varias condiciones que hay en el contexto, particularmente los procesos internos judiciales que se llevan en el Perú". ${ }^{44}$

El 5 de diciembre, la viceministra de Relaciones Exteriores de Costa Rica, Lorena Aguilar, señaló que no hubo solicitud formal de asilo diplomatico, pero reiteró que hubo una comunicacion informal de Garcia de pedido de asilo diplomatico, a lo que se le respondió que no sería admitido tal pedido.

\footnotetext{
$43 \quad \mathrm{CNN}$ en español, en: https://cnnespanol.cnn.com/video/alan-garcia-tabare-vazquez-asilorechazo-uruguay-pkg-digital-original/ (fecha de consulta: 26 de diciembre del 2019).

$44 \mathrm{CNN}$ en español, en: https://cnnespanol.cnn.com/video/asilo-politico-alan-garciaexpresidente-peruano-sot-camilo/ (fecha de consulta: 27 de diciembre del 2019).
} 


\section{Intentos fallidos}

Por otro lado, en esos mismos días, según la voz autorizada de un alto diplomático peruano, viejo amigo del expresidente García, ambos discípulos de Haya de la Torre, se gestionó el asilo diplomático ante el embajador del Ecuador en una reunión en dicha embajada. Empero, los funcionarios ecuatorianos nunca respondieron a la solicitud. Frente a la falta de comunicación ecuatoriana, se buscó otra embajada.

Se intentó contactar con los funcionarios de la embajada de Chile, infructuosamente, pues dichos funcionarios evadían cualquier reunión con tal finalidad, hasta que en un contacto posterior, que se logró después de cinco intentos, aceptaron que no querían concretar tal reunión porque afirmaban no querer comprometer las relaciones con el gobierno anfitrión. Esto pese a que el asilo diplomático es aceptado y regulado por los tratados de asilo diplomático firmados por ambos paises. La idea (la de buscar asilo diplomático en otras embajadas) era tener otras alternativas de asilo en otras sedes diplomáticas en caso que fallara la primera alternativa (i.e., si Uruguay decidiera no conceder el asilo).

\section{Negación de asilo a Hinostroza}

En relación con la lucha anti-corrupción y con el asilo, en este caso asilo territorial, cabe destacar el hecho que España rechazó el 5 de diciembre del 2018 la solicitud de asilo de César Hinostroza. Hinostroza había fugado a España en octubre previo para escapar a la justicia peruana ${ }^{45}$ En un comentario, el ex-canciller del Perú, Oscar Maúrtua de Romaña, presidente de la Sociedad Peruana de Derecho Internacional, saludó la decision del gobierno español y manifestó que esta decisión verifica la existencia en el Perú de una plena democracia así como de un estado de derecho y por ende de la separación de poderes del Estado. Agregó que dicha determinación evidencia el compromiso de la comunidad internacional en la lucha contra

$45 \quad$ RPP en: https://rpp.pe>politica $>$ judiciales $>$ cesar-hinostroza-espana-rechazo-lasolicitud-de-asilo (fecha de consulta: 31 de diciembre del 2019). También: Peru21 en: https://peru21.pe>politica>espana-rechazo-pedido-asilo-cesar-hinostroza (fecha de consulta: 31 de diciembre del 2019). 
la corrupción y la impunidad. Asimismo, afirmó que en el Perú no habia persecución política. ${ }^{46}$

\section{CONCLUSIONES}

El asilo diplomático reconocido como regla de Derecho Internacional Americano surge en el siglo XIX. El asilo diplomático si bien se desarrolló a partir de la práctica, la costumbre y los tratados regionales que regulan este tipo de asilo, el momento fundamental vino con el caso de asilo de Haya de la Torre y la jurisprudencia de la Corte Internacional de Justicia sobre dicho caso. El caso de Asilo y la jurisprudencia de la CIJ sirvieron de aliciente para formular la Convención de Caracas de 1954, que es la norma angular vigente en América Latina.

Alan García recibió una denegación a su solicitud de asilo diplomático por parte del gobierno de Uruguay debido a que dicho gobierno consideró que no es un perseguido político y al hecho que era investigado por el poder judicial, en un Estado democrático, por un delito común como es corrupción. Esa consideración también la sostuvo el gobierno de Costa Rica que de igual manera denegó la solicitud informal de asilo de García.

\footnotetext{
46 Declaraciones del ex-canciller Oscar Maúrtua en, https://andina.pe/agencia/ noticia-rechazo-asilo-a-cesar-hinostroza-reafirma-existencia-plena-democraciaperu-735058.aspx (fecha de consulta 15 de enero del 2020).
} 


\section{Anexo 1: \\ Los Estados Parte de la \\ Convención de Asilo Diplomático de Caracas de 1954}

La Convención fue adoptada por la Décima Conferencia Interamericana celebrada en Caracas el 28 de marzo de 1954. Entró en vigor el 29 de diciembre de 1954 (conforme con el art. 23 de la Convención). Tiene 14 Estados Parte.

\begin{tabular}{|l|l|l|}
\hline Estados signatarios & Firma & Ratificación o adhesión \\
\hline Argentina & 28 de marzo de 1954 & 15 de febrero de 1993 \\
\hline Bolivia & 28 de marzo de 1954 & - \\
\hline Brasil & 28 de marzo de 1954 & 25 de junio de 1957 \\
\hline Chile & 28 de marzo de 1954 & - \\
\hline Colombia & 28 de marzo de 1954 & - \\
\hline Costa Rica & 16 de junio de 1954 & 13 de enero de 1955 \\
\hline Cuba & 28 de marzo de 1954 & - \\
\hline Ecuador & 28 de marzo de 1954 & 20 de marzo de 1955 \\
\hline El Salvador & 28 de marzo de 1954 & 6 de setiembre de 1954 \\
\hline Guatemala & 28 de marzo de 1954 & 5 de marzo de 1983 \\
\hline Haití & 28 de marzo de 1954 & 18 de enero de 1955 \\
\hline Honduras & 28 de marzo de 1954 & - \\
\hline México & 28 de marzo de 1954 & 25 de enero de 1957 \\
\hline Nicaragua & 28 de marzo de 1954 & - \\
\hline Panamá & 28 de marzo de 1954 & 16 de enero de 1958 \\
\hline Paraguay & 28 de marzo de 1954 & 4 de octubre de 1956 \\
\hline Perú & 22 de enero de 1960 & 21 de mayo de 1962 \\
\hline República Dominicana & 28 de marzo de 1954 & 17 de noviembre de 1961 \\
\hline Uruguay & 28 de marzo de 1954 & 6 de junio de 1967 \\
\hline Venezuela & 28 de marzo de 1954 & 15 de diciembre de $1954 *$ \\
\hline
\end{tabular}

*El depósito se realizó el 29 de diciembre de 1954.

Fuente: OEA, en: http://www.oas.org/juridico/spanish/firmas/a-46.html (fecha de consulta: 28 de diciembre del 2019). 



\section{LA SOlidARIDAd AMERICANA EN TIEMPOS DEL COVID-19: El bloqueo a Cuba THE AMERICAN SOLIDARITY IN TIMES OF COVID-19: The BLOCKADE of Cuba} Alexander Antialón Conde*

\section{RESUMEN}

Recientemente tuvo lugar un embargo de materiales de salud necesarios para hacer frente a la pandemia del Covid-19, en perjuicio de Cuba, país que afronta 58 años de bloqueo por parte de los EEUU., lo cual develó la indiferencia regional así como serias deficiencias en la forma cómo se viene conduciendo el sistema interamericano.

\footnotetext{
Abogado UIGV. Magíster en Ciencia Política y Gobierno con Mención en Relaciones Internacionales PUCP. Miembro Titular y Coordinador General en la Sociedad Peruana de Derecho Internacional (SPDI). Editor de la Revista Peruana de Derecho Internacional. Editor y coautor del libro Derecho Internacional Público (Fondo editorial de la URP, 2019). Ha sido profesor universitario. Becario del $55^{\circ}$ Seminario de Derecho Internacional (ONU Ginebra, 2019) y de la 2da. edición de los Cursos de Invierno de la Academia de La Haya de Derecho Internacional (2020).

Artículo dedicado a la memoria del Embajador Luis Marchand Stens (1930-2012), quien el 5 de abril de 2020 cumpliría 90 años de edad. El Embajador Marchand fue Ministro de Relaciones Exteriores, Representante Permanente del Perú ante la OEA, Miembro del Comité Jurídico Interamericano y Presidente de la Sociedad Peruana de Derecho Internacional (SPDI). La Revista Peruana de Derecho Internacional le dedicó, como correspondía, una edición especial en su número 146 mayo-agosto de 2012. Asimismo, el Consejo Directivo actual de la SPDI -el cual integro y que dirige con dedicación el Embajador Oscar Maúrtua de Romaña- acordó por unanimidad, el 28 de setiembre de 2017, nombrarlo como Miembro Emérito fallecido.
} 
Palabras clave: Bloqueo, crimen de lesahumanidad, Cuba, exterminio, intervención, multilateralismo, Organización de los Estados Americanos OEA, Secretario General, solidaridad americana, unilateralismo.

\section{ABSTRACT:}

Recently, there was an embargo on the necessary health materials to face the Covid-19 pandemic, to the detriment of Cuba, a country that faces 58 years of blockade by the United States, which revealed regional indifference as well as serious deficiencies in the way the inter-American system has been conducted.

Keywords: Blockade, crime against humanity, Cuba, extermination, intervention, multilateralism, Organization of American States - OAS, Secretary General, American solidarity, unilateralism.

\section{LA SOLIDARIDAD AMERICANA}

La solidaridad americana, como concepto del derecho internacional, tiene su origen en el Congreso de Panamá de 1826 y a partir de allí ha sido expuesta en los distintos documentos emanados de las Conferencias Panamericanas.

Antonio Manero, retrocede un poco más en la historia, para definir el origen, no del concepto, sino de la acción solidaria misma:

La historia de la solidaridad continental tiene como origen la guerra de independencia de América. He aquí la primera capital confirmación del principio de unión asentado antes.

Estados Unidos hicieron su independencia los primeros. México por su situación topográfica no tuvo ayuda material de los países del Sur, pero toda la América austral consumó solidariamente su independencia. Las armas triunfadoras de San Martín y Bolívar, partiendo unas del Sur y 
otras del Norte, llegaron simultáneamente a la línea del Ecuador. Las primeras tentativas de Congresos y Confederaciones principian tan luego como la independencia fue consumada.

De 1810 a 1821 se anuncian en Chile, Argentina y Perú movimientos unionistas; Colombia por 1822 pacta alianzas fraternales con Perú y con México. En 1826 Bolívar convoca al Gran Congreso de Panamá. Colombia, Centro-América, Perú y México firman tratados de alianza política y militar. (Manero, 1918: 178-179)

Por su parte, la Carta de la OEA (1948), establece en su artículo primero:

\section{Artículo 1}

Los Estados americanos consagran en esta Carta la organización internacional que han desarrollado para lograr un orden de paz y de justicia, fomentar su solidaridad, robustecer su colaboración y defender su soberanía, su integridad territorial y su independencia. Dentro de las Naciones Unidas, la Organización de los Estados Americanos constituye un organismo regional [...].

Asimismo, en el artículo 3 d) de la misma Carta, se enuncia la solidaridad americana, entre los principios de los Estados americanos. Señala el artículo 3 d):

La solidaridad de los Estados americanos y los altos fines que con ella se persiguen, requieren la organización política de los mismos sobre la base del ejercicio efectivo de la democracia representativa.

\section{SOLIDARIDAD CON CUBA}

Naturalmente, por el hecho que Cuba no tenga una democracia representativa, no debe suponer que no sea beneficiario de la solidaridad americana.

Raúl Porras Barrenechea, en su famoso discurso de 1960 ante la VII Reunión de Cancilleres de la OEA, citó hasta diez veces la palabra solidaridad. Transcribiremos la referencia a solo una de ellas: 
Si Europa, tensa de rivalidades, de credos y de castas, fue siempre, según Jaspers, el continente de la lucha y de la guerra, en América se han favorecido en todo momento las fuerzas de integración de sus diversos elementos étnicos, buscando en los principios del derecho y no en la fuerza el lazo de una permanente solidaridad política. América Latina, distinta fundamentalmente de los Estados Unidos por su individualismo exagerado, su idealismo tenaz, su entusiasmo por las ideas puras y los dogmas políticos, la indisciplina de su vida política, su culto de las ideas de humanidad e igualdad, ha erigido particularmente como norma de su vida internacional la proscripción de la fuerza y la exclusión de los elementos perturbadores del orden y las doctrinas disociadoras de otras partes del mundo, que chocan, como dijo Sáenz Peña, con la fecundidad del suelo americano y con los sentimientos de clemencia y generosidad propios de nuestra raza. De estas inclinaciones pacíficas y solidarias han surgido los postulados, que se han impuesto en las Conferencias Panamericanas, de exclusión de toda hegemonía política, de defensa de la paz y de las soluciones pacíficas de las controversias internacionales, de respeto de los derechos fundamentales de la persona humana, de culto de la armonía y de la tolerancia, de instituciones como el asilo que proscribe la persecución y la venganza y que han dado lugar, como dijo García Calderón, a una confederación moral sin pactos escritos y sin rudas sanciones. (Porras, 1960)

Siendo la solidaridad americana un concepto tan propio de nosotros, concretamente los latinoamericanos, me llamó profundamente la atención la denuncia que realizó el 1 de abril (2020) la Presidencia de Cuba, desde su cuenta oficial en twitter, declarando que una "donación de suministros médicos a Cuba para combatir el Covid-19, de la fundación china Alibabá, no ha podido llegar por regulaciones del criminal bloqueo del gobierno de EE.UU..."1

En efecto, se trataba de una donación de 100.000 mascarillas y 10 equipos para diagnosticar el COVID-19, así como respiradores artificiales, guantes y otros materiales de salud. Los funcionarios cubanos aseguraron que la división de transporte de carga de Avianca Airlines, con sede en

Enlace electrónico: https://twitter.com/PresidenciaCuba/status/1245290570140004353 
Colombia, declinó a última hora trasladar la asistencia a Cuba porque la principal accionista de la aerolínea es una compañía con sede en Estados Unidos y está obligada a acatar el embargo comercial contra Cuba. ${ }^{2}$

Ante tan lamentable situación, desde el 2 de abril viene circulando en las redes sociales una carta abierta puesta a la firma de los ciudadanos del mundo, para respaldar a Cuba en su pedido al Reino Unido para que intervenga ante los EE.UU. para poner fin al bloqueo contra la isla-que a propósito está próximo a cumplir los 60 años y que "hoy resulta una política completamente obsoleta" (Maúrtua, 2010: 56)- o al menos suspenderlo durante la crisis por el Covid-19. Por supuesto, quien escribe, con todo agrado, se sumó a la causa.

Cuba apela la reciprocidad del Reino Unido, pues, como se recuerda, el 18 de marzo pasado, el gobierno cubano ofreció refugio a los pasajeros del crucero británico MS Braemar, permitiéndole atracar en La Habana, cuando otros países se negaron a hacerlo. El Secretario de Relaciones Exteriores británico, Dominic Raab, agradeció públicamente a Cuba por esta ayuda, en una declaración al Parlamento británico.

\section{CRIMEN DE LESA HUMANIDAD}

El Estatuto de Roma en su artículo 7(1) establece como crimen de lesa humanidad, el exterminio; señalando que dicho crimen: "comprenderá la imposición intencional de condiciones de vida, entre otras, la privación del acceso a alimentos o medicinas, entre otras, encaminadas a causar la destrucción de parte de una población".

El bloqueo en tiempos del Covid-19, ya no es solo un acto de intervención en materia económico-financiera o de injerencia en los asuntos internos o externos de otro país, que de por sí ya es grave, conforme al derecho internacional, a las normativas americanas sobre la no intervención,

2 Ver XinhuaNet (http://www.xinhuanet.com/english/2020-04/02/c_138940371.htm); Infobae (https://www.infobae.com/america/agencias/2020/04/04/embargo-de-eeuubloquea-ayuda-enviada-a-cuba-por-covid-19/); entre otros medios. 
a la propia Carta de la OEA, a las doctrinas Monroe, Calvo, Drago y Estrada, $\mathrm{y}$, a las decisiones de la Corte Internacional de Justicia relacionas a la no intervención. ${ }^{3}$ Lo acontecido contra Cuba ya es materia de competencia de la Corte Penal Internacional, pues concurren los requisitos para la calificación de exterminio, según el Estatuto de Roma.

En tal contexto, la pregunta cae por su propio peso ¿qué se puede hacer para ayudar a Cuba? Siendo realistas, poco; pero ese poco ya sería algo. Nuestra hermana Cuba ha tenido que recurrir al Reino Unido, toda vez que en 58 años no ha encontrado un apoyo efectivo de parte de nosotros, los latinoamericanos.

Se me ocurre la creación de un Grupo de Solidaridad Americana, liderado por uno de los presidentes de los Estados miembros de la organización y, por supuesto, con el compromiso solidario-humanitario de los demás países. Más allá de interceder contra el bloqueo o realizar pronunciamientos, la tarea principal del Grupo sería llevar ayuda efectiva que mitigue las principales necesidades de la isla. Sería como un homenaje a la memoria de Porras (Perú), de Carranza (México), del propio Monroe (EE. UU) tal vez, y otros.

\section{DEFUNCIÓN DEL MULTILATERALISMO EN LAS AMÉRICAS}

¿Alguien todavía cree que América se rige por el multilateralismo (regional)? Lo acontecido contra Cuba y la nula reacción de las instituciones regionales (y también mundiales), revelan la defunción del multilateralismo (ya no es solo crisis, la crisis ya pasó). El hecho que se conformen grupos de Estados o un gran grupo de Estados como lo es la OEA, en América, no la convierte a esta al multilateralismo, si esa masa de pequeños países están al servicio de una potencia; eso no es multilateralismo. El multilateralismo no se define solo por la cantidad de Estados representados en las instituciones,

\footnotetext{
3 A mayor abundamiento sobre el Principio de No Intervención en las Américas, ver: ANTIALON, Alexander. (2019). Vigencia del Principio de No Intervención en las Américas. En Revista Peruana de Derecho Internacional, Tomo LXIX, N 161 , eneroabril 2019, pp. 169-193.
} 
sino por la acción y decisión conjunta, soberana, independiente e igualitaria de todos ellos, así como por el cumplimiento de los principios y reglas con que cuenta la institución y que aseguran la no imposición de la voluntad del más fuerte.

$\mathrm{Al}$ respecto, Antonio Remiro Brotóns, nos esclarece:

Ciertamente, el unilateralismo de Estados Unidos como poder arrogante es particularmente intenso desde que el Sr. Trump accedió a la presidencia y muy inquietante la pretensión de extraterritorialidad de sus decisiones, internacionalmente ilegales, a las que se somete un buen número de gobiernos, bancos y empresas ante la advertencia y el temor de pagar las consecuencias de una falta de compliance en los mercados que, directa o indirectamente, controla la gran Potencia. (Remiro, 2020: 23-24)

\section{REFORMA DE LA OEA}

Convencido en lo personal de que la OEA no desaparecerá, sino hasta el final de los tiempos, habría que buscar fórmulas de modo tal que la voluntad de uno, no se termine imponiendo a la de los demás, ya sea por presión o algún tipo de injerencia, tal como ocurría v.g. al momento del discurso de Porras, quien fue a San José con la orden presidencial de secundar la posición de los EE.UU. a favor de la condena contra la isla, pero que no lo hizo sino que antepuso sus convicciones por el derecho internacional y la solidaridad americana.

Una reforma podría empezar por el modo de elegir al Secretario General, para el cual, dicho sea de paso, no debería haber reelección inmediata. La Asamblea General podría delegar la elección, a una institución respetable del mundo, quizá de Ginebra o La Haya, que pueda escoger a un ciudadano americano que goce de prestigio e independencia, además de conocer la realidad y problemática americana.

¿Habría algo que perder? Yo creo que no. 


\section{BIBLIOGRAFÍA}

Antialon, Alexander. (2019). Vigencia del Principio de No Intervención en las Américas. En Revista Peruana de Derecho Internacional, Tomo LXIX, $\mathrm{N}^{\circ}$ 161, enero-abril 2019, pp. 169-193.

Antialon, Alexander. (2019). Derecho Internacional Público. [Editor y Coautor]. Universidad Ricardo Palma y Sociedad Peruana de Derecho Internacional. Lima.

Manero, Antonio. (1918) México y la Solidaridad Americana. La Doctrina Carranza. Editorial América, Madrid. Enlace electrónico: https://ia800907.us.archive.org/34/items/mexicoylasolidar00mane/ mexicoylasolidar00mane.pdf

Maúrtua, Oscar. (2010). Apuntes sobre la Agenda Interamericana. México D.F.: Plaza y Valdes editores.

Porras, Raúl. (1960). Discurso de Raúl Porras Barrenechea ante la VII reunión de Cancilleres de la OEA - San José de Costa Rica, 23 de agosto de 1960).

Remiro, Antonio. (2020). La Declaración sobre los Principios cumple cincuenta años. Revista Española de Derecho Internacional, Vol. $72 \mathrm{~N}^{\circ} 1$, 2020, pp. 17-25.

Ulloa, Alberto. (1943). Nota bibliográfica sobre "La solidaridad internacional en América" de Alberto Guani (Montevideo, 1942). En Revista Peruana de Derecho Internacional Tomo III, N 9, p. 372. 


\title{
Principios de Derecho Internacional de los Derechos Humanos aPliCABLES EN ESTADO DE EMERGENCIA COVID-19 Y EL USO DE LA FUERZA POR PARTE DEL PERSONAL
} POLICIAL

\author{
Principles of International LaW of Human Rights apPlicable \\ IN A STATE OF EMERGENCY COVID-19 AND THE USE OF FORCE BY
} POLICE PERSONNEL

Carolina Loayza-Tamayo*

\section{RESUMEN}

Se analiza si las medidas adoptadas por el Perú para enfrentar la emergencia COVID19 observan los estándares y los principios internacionales de derechos humanos contenidos en la Guía sobre el uso de la fuerza por parte del personal policial en tiempos de emergencia COVID-19 adoptado por la Relatora Especial de las Naciones Unidas sobre ejecuciones extrajudiciales, sumarias o arbitrarias: Los estados de emergencia son excepcionales y de duración limitada, el derecho a la vida no es derogable, las medidas de aplicación de la ley deberían guiarse por los principios de

\footnotetext{
Abogada, con estudios de Maestría en Derecho Constitucional y Derechos Humanos, y de Doctorado en Derecho en la Universidad Nacional Mayor de San Marcos, Profesora de la Universidad Tecnológica del Perú, abogada litigante en el Sistema Interamericano de Derechos Humanos.

Con el presente artículo, la autora formaliza su incorporación como Miembro Asociada, conforme a lo dispuesto por el Consejo Directivo de la Sociedad Peruana de Derecho Internacional, mediante Acta del 13 de diciembre de 2018.
} 
legalidad, necesidad, proporcionalidad, precaución y no discriminación, las medidas de emergencia no deberían incrementar el riesgo de los grupos vulnerables, y la policía debería operar bajo los principios de discusión, instrucción, consulta y participación comunitaria, en atención a que tales contextos históricamente han conducido a un aumento de la violencia por parte del Estado, principalmente contra personas y comunidades vulnerables por parte de los funcionarios a cargo de su aplicación.

Palabras clave: Derecho internacional de los derechos humanos; estados de emergencia; COVID19; Principios de legalidad, necesidad, proporcionalidad, precaución y no discriminación; Principios de discusión, instrucción, consulta y participación de la comunidad; personas y comunidades vulnerables; uso de la fuerza; uso excesivo de la fuerza; derecho a la vida; personal encargado de hacer cumplir la ley.

\section{ABSTRACT}

It is analyzed whether the measures adopted by Peru to face the COVID19 emergency observes the international human rights standards and principles contained in the Guidance on the use of force by law-enforcement personnel in time of COVID-19 emergency adopted by the United Nations Special Rapporteur on Extrajudicial, Summary or Arbitrary Killings: States of emergency are exceptional and strictly limited, the right to life is nonderogable, law-enforcement measures should be guided by the principles of legality, necessity, proportionality, precaution and non-discrimination, emergency measures should not increase the risk of vulnerable groups, and the police should operate under the principles of discussion, instruction, consultation and community engagement, considering that such contexts have historically led to an increase in violence by the State, mainly against vulnerable people by law enforcement personnel.

Keywords: International human rights law; state of emergency; COVID19; Principles of legality, necessity, proportion, precaution and non-discrimination; Principles of discussion, instruction, consultation and community engagement; vulnerable individuals and communities; use of force; excessive use of force; right to life; law enforcement personnel. 
La pandemia del COVID $19^{1}$ ha dado lugar a que muchos gobiernos hayan decretado excepcionalmente estados de emergencia y el aislamiento social obligatorio, ${ }^{2}$ implantando el toque de queda para garantizar el cumplimiento de las medidas de emergencia adoptadas y se evite su contagio masivo. Esta medida ha generado un conjunto de denuncias relacionadas al uso excesivo de la fuerza por parte del personal policial, principalmente contra personas y comunidades vulnerables, como las personas de pobreza extrema que viven solo con lo suficiente para satisfacer las necesidades básicas, personas en situación de calle, mujeres y niños en situación de violencia doméstica y agresión sexual, migrantes y refugiados, habitantes de zonas deprimidas para quienes la actividad económica diaria es esencial para la supervivencia diaria y las comunidades LGBTI. Otros Grupos vulnerables lo conforman los nacionales y extranjeros en busca de

$1 \quad$ La Organización Mundial de la Salud - OMS con fecha 11 de marzo de 2020 ha calificado el brote del COVID-19 como una pandemia al haberse extendido en más de cien países del mundo de manera simultánea.

2 El Gobierno del Perú mediante Decreto Supremo N$^{\circ}$ 008-2020-SA publicado en el Diario Oficial El Peruano el 11 de marzo de 2010 declaró la Emergencia Sanitaria a nivel nacional por el plazo de noventa (90) días calendario, y se dictaron medidas de prevención y control para evitar la propagación del COVID19; declarando mediante Decreto Supremo $\mathrm{N}^{\circ}$ 044-2020-PCM publicado en el Diario Oficial El Peruano el 15 de marzo de 2020, y por el término de quince días calendario, el Estado de Emergencia Nacional, se dispuso el aislamiento social obligatorio (cuarentena) por las graves circunstancias que afectan la vida de la Nación a consecuencia del brote del COVID-19, y la restricción del ejercicio de los derechos constitucionales relativos a la libertad y la seguridad personales, la inviolabilidad de domicilio, y la libertad de reunión y de tránsito en el territorio. El Decreto Supremo N 046-2020-PCM, precisa el artículo 4 del Decreto Supremo $N^{\circ}$ 044-2020-PCM, con la finalidad de adoptar acciones complementarias que precisen las limitaciones al ejercicio del derecho a la libertad de tránsito de las personas en el marco del Estado de Emergencia Nacional. El Decreto Supremo No 051-2020-PCM de fecha 27 de marzo de 2020, prorroga el Estado de Emergencia Nacional declarado mediante Decreto Supremo N ${ }^{\circ} 044-$ 2020-PCM, y establece la inmovilización social obligatoria de todas las personas en sus domicilios desde la veinte (20) horas hasta las cinco (5) horas del día siguiente, posteriormente se ha ampliado el horario del toque de queda. El día 9 de abril de 2020, el Gobierno del Perú ha dispuesto una nueva prórroga. 
repatriación a los países de su residencia como consecuencia del cierre de fronteras y de aeropuertos. ${ }^{3}$

La Relatora Especial de las Naciones Unidas sobre ejecuciones extrajudiciales, sumarias o arbitrarias, Agnes Callamard, reconoce que "el COVID19 es nuevo" pero "las normas de derechos humanos aplicables [a estas situaciones de emergencia] no lo son." El 2 de abril de presente año, publicó una Guía sobre el uso de la fuerza por parte del personal policial en tiempos de emergencia COVID- $19,{ }^{4}$ que se basa en los siguientes principios:

- Los estados de emergencia son excepcionales; su duración debe ser estrictamente limitada

- El derecho a la vida no es derogable.

- Las medidas de aplicación de la ley deben guiarse por los principios de legalidad, necesidad, proporcionalidad, precaución y no discriminación. Estos son principios fundamentales del derecho internacional de los derechos humanos que vincula a todos los Estados.

- Los grupos vulnerables, como los pobres, los trabajadores migrantes y las personas sin hogar, ya están afectados de manera desproporcionada por el virus. No debería incrementarse el riesgo debido a las medidas del estado de emergencia. La policía debe tomar medidas de precaución adecuadas y con estándares altos, llevando a cabo una evaluación basada en el contexto de si el uso de la fuerza es necesario y proporcionado.

- Discusión, instrucción, consulta y participación comunitaria: estos deberían ser los principios operativos para la policía.

La Relatora, señala que "[1]a historia nos dice que, en la mayoría de los casos, los estados de emergencia y los toques de queda, independientemente

3 El Decreto Supremo $N^{\circ}$ 045-2020-PCM precisa los alcances del artículo 8 del Decreto Supremo $\mathrm{N}^{\circ}$ 044-2020-PCM estableciendo medidas para facilitar la repatriación de nacionales peruanos y de extranjeros a sus respectivos países de residencia; así como el aislamiento social obligatorio para las personas que retornen al país.

$4 \quad$ United Nations Special Rapporteur on Extrajudicial, Summary or Arbitrary Killings. Guidance on the use of force by law-enforcement personnel in time of COVID-19 emergency. United Nations - Human Rights Special Procedures. \#COVI19 HUMAN RIGHTS DISPATCH - NUMBER 1 POLICE AND MILITARY USE OF FORCE IN A STATE OF EMERGENCY. Recuperado de: https:/www.ohchr.org/Documents/ Issues/Executions/HumanRightsDispatch1.pdf 
de su pretendida motivación, conducen a un aumento de la violencia por parte del Estado"; lo que respondería a: leyes mal redactadas o imprecisas, otorgamiento de poderes excepcionales excesivos a los funcionarios encargados de la aplicación de la ley, la existencia de una cultura institucional policial que tolera el uso de la fuerza, incremento de la tolerancia pública a la violencia policial en circunstancias de amenazas reales o percibidas, debilitamiento de los mecanismos institucionales de monitoreo de la actuación policial, censura de la prensa y supresión del escrutinio de la sociedad civil; así como a la deshumanización de ciertos grupos de la sociedad civil. Remarcando que, el derecho a la vida es inderogable, incluso en estados de emergencia. En ese sentido, el uso de la fuerza incluidas las armas de fuego debe regirse por la legislación nacional de conformidad con las obligaciones internacionales, por lo que el uso excesivo de la fuerza "por parte de la policía siempre es ilegal según el derecho internacional, incluso durante los estados de emergencia" (artículo $4^{\circ}$ del Pacto Internacional de Derechos Civiles y Políticos).

Disposiciones similares encontramos en el Convenio Europeo de Derechos Humanos (artículo $15^{\circ}$ ) y en el artículo de la $27^{\circ}$ de la Convención Americana sobre Derechos Humanos. Este último, permite que en caso de peligro público o de otra emergencia que amenace la seguridad de un Estado parte, "éste podrá adoptar disposiciones, en la medida y por el tiempo estrictamente limitados a las exigencias de la situación," siempre que tales disposiciones no sean incompatibles con las demás obligaciones que les impone el derecho internacional y no entrañen discriminación alguna, y siempre que no sea objeto de restricción alguna el núcleo duro de derechos, como el derecho a la Vida, el derecho al reconocimiento de la Personalidad Jurídica, el derecho a la Integridad Personal, la Prohibición de la Esclavitud y Servidumbre, el Principio de Legalidad y de Retroactividad, la Libertad de Conciencia y de Religión, la Protección a la Familia, el Derecho al Nombre, los Derechos del Niño, el Derecho a la Nacionalidad, los Derechos Políticos, ni las garantías judiciales indispensables para la protección de tales derechos. La decisión de los Estados de hacer uso del derecho de suspensión conlleva la obligación de informar inmediatamente a los demás Estados Parte de la Convención Americana sobre Derechos Humanos por conducto del Secretario General de la Organización de los Estados Americanos, de las 
disposiciones cuya aplicación haya suspendido, de los motivos que hayan suscitado la suspensión y de la fecha en que haya dado por terminada tal suspensión. ${ }^{5}$

Si bien, se reconoce que en un estado de emergencia, incluido el toque de queda, se puede otorgar legítimamente más poderes a los agentes del orden, esa opción NUNCA incluye "el poder" de quitar la vida arbitrariamente. Por lo que, los funcionarios encargados de hacer cumplir la ley, si recurren a la fuerza deben observar e implementar los Principios de necesidad, proporcionalidad y precaución. Los principios de proporcionalidad y el principio de necesidad, limitan el uso de la fuerza letal por parte de los agentes de policía en situaciones donde el objetivo principal debe ser salvar vidas. La Guía, precisa los contenidos de dichos principios:

Principio de Necesidad: Los funcionarios encargados de hacer cumplir la ley solo pueden usar la fuerza cuando sea estrictamente necesario y solo en la medida necesaria para el desempeño de sus funciones, debiendo evitar en la medida de lo posible, el uso de la fuerza y de las armas de fuego, agotando los medios no violentos antes de recurrir a medios violentos. De forma tal que las armas de fuego no se utilizarán contra personas excepto: i) en defensa propia, ii) en defensa de otros contra la amenaza inminente de muerte o lesiones graves, iii) para prevenir un delito particularmente grave que implique grave amenaza para la vida, iv) o arrestar a una persona que presente tal peligro.

Principio de Proporcionalidad: La fuerza utilizada debe ser proporcional al objetivo legítimo a ser alcanzada. De usarse la fuerza letal, las restricciones deben ejercerse en todo momento y los daños y/o lesiones mitigados, incluso mediante una advertencia clara de la intención de usar la fuerza, proporcionando suficiente tiempo para prestar atención

Juan Carlos Hitters y Oscar Fappiano. Derecho Internacional de los Derechos Humanos. Tomo I Volumen 2. 2a . Edición. Buenos Aires, EDIAR, 2007, p. 670. La Corte Interamericana de Derechos ha desarrollado una interesante jurisprudencia dando criterios sobre la aplicación del artículo $27^{\circ}$ de la Convención Americana sobre Derechos aunque no en situaciones de emergencia por pandemia, principalmente en sus Opiniones Consultivas OC-8 y OC-9. Véase https://www.corteidh.or.cr/docs/ opiniones/seriea_08_esp.pdf y https://www.corteidh.or.cr/docs/opiniones/seriea_09_ esp.pdf 
a esa advertencia y brindar asistencia médica lo antes posible cuando sea necesario. Los funcionarios encargados de hacer cumplir la ley deben estar facultados para poner en riesgo la vida solo con el fin de salvar o proteger otras vidas.

Principio de Precaución: Se deben adoptar precauciones razonables para evitar la pérdida de vidas. Lo que incluye colocar estructuras apropiadas de mando y control; prever la formación adecuada de los funcionarios encargados de hacer cumplir la ley en el uso de la fuerza, incluidas técnicas menos letales; $y$, cuando sea posible, requerir la emisión de una advertencia clara antes de usar la fuerza; y asegurar que la asistencia médica esté disponible.

En ese contexto, la Guía señala que los estados de emergencia restringen la libertad de movimiento, lo que aumenta la vulnerabilidad de las personas pobres obligadas a salir para ganarse la vida, personas sin hogar, mujeres y niños en situación de violencia doméstica, migrantes y refugiados, población de barrios marginales y todas aquellas personas que viven con lo suficiente para sus necesidades básicas y para quienes la actividad económica diaria es esencial para su supervivencia. Estas personas no solo están más expuestas al contagio sino a la violencia policial e incluso al uso de la fuerza letal, al no acatar las disposiciones de emergencia. Esta situación se agrava cuando la ley no contempla estas situaciones. Por lo que, la Relatora recomienda que los criterios de vulnerabilidad y los riesgos a la vida y la dignidad se integren en el diseño e implementación de las regulaciones de emergencia, para protegerlos contra el uso excesivo de la fuerza por parte de la policía, que en ninguna circunstancia debería conducir al uso de la fuerza letal. Lo contrario sería ir en contra del objetivo principal de tales medidas: salvar vidas.

El gobierno peruano, ha dado claras evidencias de estar tratando de observar estos principios, adoptando diversas medidas para aminorar los efectos de la pandemia en la población peruana. Al menos en la ciudad de Lima, se ha adoptado medidas respecto de las personas en situación de calle; y a nivel nacional se dispuso el aislamiento social, el toque de queda, la obligación de llevar mascarillas; como medidas económicas de contención frente al coronavirus se ha dispuesto el otorgamiento de una asignación económica para mujeres jefes de familia de edad entre 18 y 60 
años en situación de pobreza y de extrema pobreza, ${ }^{6}$ la entrega de productos esenciales de la canasta básica familiar como alimentos a familias en condición de pobreza y extrema pobreza a través de gobiernos locales, ${ }^{7}$ la autorización de retiro de una parte del fondo de pensiones de las AFP $;^{8}$ así como regulaciones específicas en casos de incumplimiento de las normas de emergencia. A efecto de fortalecer el cumplimiento de las disposiciones de emergencia, el gobierno dispuso la intervención conjunta de la policía y de las fuerzas armadas. ${ }^{9}$

Algunas de estas medidas vienen siendo modificadas a partir del comportamiento de la población. Así el aislamiento social con autorización

6 El Ministerio de Desarrollo e Inclusión Social viene entregando el bono económico de S/ 380 a las mujeres en general de las familias más pobres que fluctúan en las edades de 18 a 60 años, para ayudarlas a quedarse en casa a fin de hacer frente a la pandemia del coronavirus. La entrega del bono solidario beneficiará a 2.7 millones de familias pobres y de extrema pobreza del país, a los que se sumarán 800 mil familias de trabajadores independientes no considerados en la lista del Ministerio de Desarrollo e Inclusión Social - MIDIS que será canalizado por el Ministerio de Trabajo.

El Poder Ejecutivo anunció el 26 de marzo de 2020, la transferencia de 200 millones a los gobiernos locales provinciales y distritales para la entrega de víveres a los más pobres, a las familias en condición de pobreza y extrema pobreza, previo empadronamiento por dichas autoridades, adoptando el Decreto de Urgencia $\mathrm{N}^{\circ} 033$ 2020 que en su en su artículo 2, autoriza a los gobiernos locales, de manera excepcional durante el Año Fiscal 2020, efectuar la adquisición y distribución de víveres con un presupuesto de 213,650,000 soles. Más de 1,800 municipalidades han sido consideradas en este programa de apoyo a las poblaciones vulnerables en todo el país. A efecto de la transparencia de la rendición de cuentas en la contratación y la distribución de las canastas básicas familiares el órgano de control, mediante Resolución de Contraloría $\mathrm{N}^{\circ}$ 102-2020-CG, publicada el 2 de abril de 2020 en el Diario Oficial El Peruano, ha dispuesto el registro en línea en la Plataforma para la Transparencia de la Gestión Pública en la Emergencia Sanitaria COVID-19, del proceso de contratación, la ejecución del contrato y la entrega de las canastas básicas familiares para las poblaciones vulnerables. Decreto de Urgencia $\mathrm{N}^{\circ}$ 034-2020 que permite a quienes hayan dejado de aporta los últimos doce meses a la AFP, el retiro de hasta dos mil soles. El 3 de abril de 2020, el Pleno del Congreso aprobó con 107 votos la autógrafa de ley que permite la liberación del $25 \%$ de los fondos de pensiones, con un tope máximo de retiro de 12,900 soles, que se encuentra pendiente de la promulgación por el Presidente de la República.

9 Decreto Supremo No 051-2020-PCM, cuyo artículo $4^{\circ}$ dispone que "La intervención de la Policía Nacional del Perú y de las Fuerzas Armadas se efectúa conforme a lo 
para que un miembro de cada familia pueda salir para realizar determinadas actividades como compra de alimentos o medicinas, y gestiones bancarias, no impidió que el aislamiento social no fuera observado en los centros de abastos, mercados y supermercados, convirtiéndose en focos de propagación del virus por la presencia masiva de personas sin protección. La respuesta del gobierno fue ordenar el uso obligatorio de mascarillas y asignar determinados días para la realización de dichas tareas, a hombres y a mujeres.

Las primeras observaciones a dichas medidas provinieron de los grupos LGBTI, haciéndose la precisión que se respetaría en estos casos la apariencia sin exigir el documento de identidad. Sin embargo la situación aún persiste, algunos miembros de la policía continuaron solicitando documentos a miembros de los grupos LGBTI, obligándolos a realizar ejercicios repitiendo frases que afectan su dignidad. En el caso de las mujeres, estas han salido masivamente los días asignados a ellas y acompañadas por uno o más miembros de su familia para realizar las actividades autorizadas violando el aislamiento social y generando situaciones de riesgo masivo de contagio. Esta situación se ha presentado en todos los niveles socioeconómicos incluida la población en estado de pobreza, ${ }^{10}$ para quienes

dispuesto en el Decreto Legislativo $\mathrm{N}^{\circ} 1186$, Decreto Legislativo que regula el uso de la fuerza por parte de la Policía Nacional del Perú, el Decreto Legislativo $\mathrm{N}^{\circ} 1095$, Decreto Legislativo que establece reglas de empleo y uso de la fuerza por parte de las Fuerzas Armadas en el territorio nacional; y su Reglamento, aprobado por Decreto Supremo N 003-2020-DE, respectivamente."

Vienen realizándose estudios sobre el comportamiento de las mujeres en estas épocas de pandemia, que expertas atribuyen el comportamiento no solo a razones de género y a división de roles. Véase: Marcela Huaita Alegre. Cuarentena por sexos: ¿Por qué las mujeres salen más? Publicado el 6 de abril de 2020. Recuperado de: http://blog.pucp. edu.pe/blog/marcelahuaitaalegre/2020/04/06/cuarentena-por-sexos-por-que-las-mujeressalen-mas/ Huaita relaciona este comportamiento con la responsabilidad social de "las compras"; así como con "la necesidad urgente de dar de alimentar a la familia", que se explica en "en algunos casos de hogares liderados por mujeres y en zonas empobrecidas en donde no hay capacidad de guardar productos perecibles". En el caso de mujeres de otros estratos sociales, este comportamiento es el reflejo de dos fenómenos adicionales: depresión y ansiedad -consecuencia del aislamiento social-; y "el hartazgo" al estar su espacio - la casa- "invadidas" por los otros miembros de la familia, siendo sometidas a una presión mayor por estos, de atención y de satisfacción de sus necesidades -materiales como inmateriales-. En ese sentido, las salidas masivas de las mujeres constituirían válvulas de 
la actividad económica diaria es esencial para la supervivencia, y en los migrantes. También se vienen presentando casos de mujeres que salen los días asignados a los hombres mostrándose reacias a acatar las normas de emergencia y al ser cuestionadas por la autoridad policial, pretenden hacer valer su condición de mujeres para impedir su detención o la detención de sus familiares. Otro comportamiento que se ha identificado en los distritos de nivel medio o alto, es el de jóvenes que salen a las calles llevando bolsas vacías, aparentando ir a abastecerse de alimentos, y en muchos casos sin llevar mascarilla, mientras que en los distritos populares los jóvenes salen a beber en las calles, juegan fútbol o realizan fiestas no familiares, no respetando el aislamiento social ni el toque de queda.

Lo antes indicado ha determinado que en muchos casos el uso de la fuerza física por parte de los funcionarios encargados de hacer cumplir la ley sea desproporcionado y conlleve una serie de actos de abuso de autoridad, así como de violencia verbal o agresión psíquica, del innecesario uso de términos inapropiados por parte de la autoridad al ejercer su función, o de responder un agravio físico y/o verbal. Al mismo tiempo, la resistencia al cumplimiento de las medidas de emergencia por la ciudadanía, ha puesto en evidencia la falta de técnicas y la carencia de medios de los funcionarios encargados de la aplicación de las medidas de emergencia para inmovilizar y detener a ciudadanos y ciudadanas que además de resistirse a sus órdenes, los agreden. Es urgente que se observe el Principio operativo de discusión, instrucción, consulta y participación comunitaria para generar alianzas desde la comunidad para el respeto de tales medidas.

Uno de los riesgos más graves del aislamiento social son los que sufren las mujeres y niñas víctimas de violencia doméstica, habiéndose producido algunos casos. ${ }^{11}$ El Secretario General de la ONU, Antonio Guterres, ante el

escape en el que no se mide el riego que ello implica.

$11 \quad \mathrm{Al} 1^{\circ}$ de abril se reportaron que 43 mujeres fueron víctimas de violación sexual y entre ellas, 27 niñas. Diario La República. Edición online del $1^{\circ}$ de abril de 2020. Recuperado de: https://larepublica.pe/sociedad/2020/04/01/coronavirus-en-perureportan-que-27-ninas-fueron-victimas-de-violacion-sexual-durante-cuarentena/ Diario Perú 21. Edición del 5 de abril de 2020. Recuperad de: https://peru21.pe/ mundo/coronavirus-i-ultima-hora-i-onu-llama-a-proteger-a-las-mujeres-duranteconfinamiento-por-coronavirus-i-en-peru-se-han-reportado-43-violaciones-noticia/ 
incremento de la violencia doméstica en el mundo, lanzó un llamado mundial para proteger a las mujeres "en sus propios hogares", "en momentos en que las medidas de confinamiento provocadas por la pandemia de Covid19 exacerban la violencia de pareja y en las familias." ${ }^{12}$ En el Perú, el estado de emergencia decretado no ha interrumpido los servicios de atención especializada del Ministerio de la Mujer y Poblaciones Vulnerables - MIMPV a través de la Línea $100 \mathrm{ni}$ el sistema de denuncias no han dejado de funcionar, permitiéndose a las víctimas salir de su hogar para denunciar a la persona agresora y refugiarse en otro domicilio, y las comisarias siguen obligadas a recibir denuncias, los efectivos policiales continúan las detenciones en casos de flagrancia y, a nivel judicial, los magistrados siguen desarrollando audiencias en los casos que hayan detenidos o requieran medidas cautelares. ${ }^{13}$ El MIMPV ha pedido al Ministerio del Interior que se intensifique el patrullaje en las zonas donde hay mujeres que tienen medidas de protección.

Las medidas implementadas por el gobierno vienen presentando problemas en cuanto su observancia y respeto; y los funcionarios encargados de aplicar la ley, se ven enfrentados a situaciones de violencia y resistencia a su autoridad. El Gobierno no solo ha separado rápidamente de las actividades operativas a todos sus funcionarios que han violado los derechos de las personas intervenidas en violación del principio de proporcionalidad, también han creado un registro de detenidos por violar las normas de emergencia que serán procesados cuando la situación de emergencia se supere. Se visualiza un esfuerzo de las autoridades de observar las normas de derechos humanos, y la Guía sobre el uso de la fuerza por parte del personal policial en tiempos de emergencia COVID-19 elaborada por la Relatora Especial de las Naciones Unidas sobre ejecuciones extrajudiciales, sumarias o arbitrarias resulta un instrumento importante para el Perú como para todos los países del mundo que enfrentan la pandemia.

\footnotetext{
12 Véase https://rpp.pe/politica/estado/covid-19-en-medio-de-la-cuarentena-comoprotege-el-estado-a-las-victimas-de-violencia-familiar-noticia-1254585?ref=rpp

13 Consejo Ejecutivo del Poder Judicial. Resolución Administrativa N ${ }^{\circ}$ 115-2020-CEPJ de 16 de marzo de 2020; artículo Tercero, literal d) ii). Los juzgados no penales designarán al menos un juez para atender asuntos de violencia familiar, medidas cautelares, admisión de medidas de amparo, pensión de alimentos y demás casos urgentes.
} 
Desde ya el aislamiento social y el toque de queda viene afectando la salud mental y emocional de los peruanos y peruanas, principalmente de los niños y niñas, puede ocasionar estrés y agotamiento psicológico, especialmente en personas que no acostumbran estar encerradas. El gobierno a través del Ministerio de Salud viene dando pautas y distintas instituciones privadas profesionales de la salud mental vienen a través de sus sitios webs ${ }^{14}$ y las redes sociales ofreciendo apoyo y asistencia virtual. La probable prolongación del estado de emergencia es un reto que debemos enfrentar, cuyas consecuencias solo podrán establecerse en el futuro.

Sinperjuicio de que las medidas gubernamentales se vienen modificando, y corrigiendo, aún queda mucho hacer por parte del gobierno para atender a todas los grupos vulnerables a personas y comunidades vulnerables; pero también, por parte de cada uno de los peruanos y peruanas. Ninguna medida será efectiva si la población a la que está dirigida no las acompaña de modo responsable. Es hora de mostrar civismo, empatía y respeto por la vida de uno mismo, de sus familias y de todas y todos los miembros de la sociedad.

En este momento crucial de la vida de la humanidad y de nuestro país, el inicio de las actividades educativas presenta una posibilidad para cambiar el comportamiento desordenado y caótico, de falta de respeto a la ley y a la autoridad de algunos peruanos y peruanas. Es urgente una alianza docenteestudiantes en todos los niveles educativos escolar y universitario, para trasmitir las nuevas reglas de convivencia social en época de pandemia. La relación estrecha generada en este contexto entre padres y sus hijos e hijas, las nuevas formas de comunicación deben ser aprovechadas al máximo para lograr la vigencia de los derechos humanos y su respeto por todos y todas, así como de los funcionarios a cargo de la aplicación de tales medidas en tiempos de emergencia COVID-19, sin recurrir al uso de la fuerza y si recurren a ella deben observar e implementar los Principios de necesidad, proporcionalidad y precaución, sin discriminación, porque el uso excesivo de la fuerza por parte de la policía siempre es ilegal, incluso durante los estados de emergencia, donde el objetivo principal debe ser salvar vidas.

$14 \quad$ Ministerio de Salud. Proteger tu salud mental durante el aislamiento social por el coronavirus (COVID19). Recuperado de: https://www.gob.pe/8797-presidencia-delconsejo-de-ministros-proteger-tu-salud-mental-durante-el-aislamiento-social-por-elcoronavirus-covid-19 


\section{El DEBATE SOBRE EL CARÁCTER JURÍDICO DEL DERECHO DE GENTES EN HISPANOAMÉRICA DURANTE EL SIGLO XIX: La CONTRAPosición entre José Silva Santisteban y ANDRÉS BELlo}

THE DEBATE ON THE LEGAL CHARACTER OF THE LAW OF NATIONS IN SPANISH AMERICA DURING THE 19TH CENTURY: THE CONTRAST Between José Silva Santisteban and Andres Bello

Pablo Rosales Zamora*

\section{RESUMEN}

La evolución del derecho de gentes en Hispanoamérica durante el siglo XIX ha sido poco estudiada. El presente trabajo tiene como objetivo afrontar ese vacío a partir del análisis de las posturas de José Silva Santisteban y Andrés Bello sobre la juridicidad del derecho internacional. Se sostendrá que el primero concibe al derecho internacional como Derecho, mientras que el segundo se aproxima a considerarlo, simplemente, como una "colección de leyes". Para entender este debate, se acudirá a los trabajos de Becker Lorca y Richard Morse, sustentando que Silva Santisteban se inscribe en una

Doctorando en Derecho y Ciencia Política por la Universidad Nacional Mayor de San Marcos (UNMSM). Profesor de Derecho Internacional en la Facultad de Derecho de la Universidad de San Martín de Porres (USMP) y de Derecho Internacional Privado en la Facultad de Derecho y Ciencia Política de la Universidad Católica Sedes Sapientiae (UCSS). Asesor en la Oficina de Derecho Internacional Público del Ministerio de Relaciones Exteriores del Perú.

El presente artículo está dedicado al profesor Silvio Mezarina García; asimismo, se escribe como tributo a la memoria del padre Armando Nieto Vélez S.J. (1931-2017). 
postura neotomista y Bello, en una aproximación utilitarista - empirista del derecho internacional.

Palabras clave: Derecho de gentes - neotomismo - empirismo juridicidad - Hispanoamérica.

\section{ABSTRACT}

The evolution of law of nations in Spanish America during the $19^{\text {th }}$ century has been few studied. The present work has as aim covering that gap with the analysis on the José Silva Santisteban and Andres Bello's approaches on the legality of international law. This article will hold that the first author conceives properly international law as law, in contrast to the second one, who considers it only as a "collection of laws". For understanding this debate, the article will resort to the works of Becker Lorca and Richard Morse, holding Silva Santisteban represented a neo-thomist perspective and, by the contrary, Bello sustained a utilitarian and empiricist approach of international law.

Keywords: Law of nations - neothomism - empiricism - legality Spanish America.

\section{INTRODUCCIÓN}

Como es sostenido por la mayoría de historiadores del derecho internacional, a partir de los tratados de la Paz de Westfalia de 1648, se produjo la consolidación del Estado moderno y, con ello, la aparición de la disciplina del derecho internacional clásico (Cassese, 2013, pp. 31 y ss.; Franca, 2006, pp. 87 y ss.; Murphy, 2012, p. 22; Truyol y Serra, 1998, pp. 7273). El llamado "derecho de gentes" ha sufrido una evolución desde entonces, cuya centralidad historiográfica ha girado en torno al llamado ius publicum europeum, prestándose poca atención a la producción bibliográfica sobre 
esta rama del Derecho en otros lugares del orbe (Armitage, D.; Pitts, J. 2017, pp. 1 y ss.). Especialmente, poco se ha escrito sobre los internacionalistas de la etapa postcolonial en América, durante el siglo XIX.

En su libro $O$ espelho de Próspero: cultura e idéias nas Américas (1988), Morse afirma que América tiene una prehistoria europea que, si bien se caracterizó por una matriz cultural e intelectual común, esta base se bifurca, entre el siglo XII y el siglo XVII, en las llamadas opción ibérica y opción política inglesa, cuyas consecuencias en la mirada del derecho de gentes se pretenden investigar aquí, en plena efervescencia del siglo XIX (1988: pp. 26 - 72). En el caso ibérico, tenemos a un gran pensador que fue Francisco de Vitoria, el mayor representante de la Escuela de Salamanca, que opta en sus obras por un enfoque neotomista, en especial en la Relectio de Indis; en cambio, la vertiente inglesa se inclinó por un enfoque empirista, en el pensamiento de autores como Locke y Hobbes (Morse 1988: pp. 59-66). En esta tensión, la visión de Vitoria, que influirá en Hugo Grocio, supone el reconocimiento de un derecho de gentes desde una mirada iusnaturalista, que se inclina en aceptarlo como rama jurídica que no se puede desconocer (Gómez Robledo, 1989: pp. 30 y ss.), mientras que Hobbes niega su juridicidad. Una visión respalda el derecho de gentes y otra visión descarta, de plano, su esencia jurídica.

Esta discusión va a dar origen en Europa, por un lado, a una serie de negadores de la juridicidad del derecho internacional y, por otro lado, a defensores de esta. Siguiendo esta división, se ha identificado dos grandes autores sudamericanos del siglo XIX que encarnan la división teórica esgrimida por Morse. Por una parte, se encuentra el peruano Silva Santisteban, que se inclinó por defender el derecho internacional como ciencia "que trata de arreglar las relaciones internacionales según los principios eternos de justicia" (1856, p. 57). Por otra parte, Bello, estudioso venezolano que radicó en Chile, sostuvo que el derecho de gentes es, simplemente, una "colección de leyes o reglas generales de conducta que las naciones o Estados deben observar entre sí para su seguridad y bienestar común” (1864, p. 13).

A partir del modelo teórico elaborado por Morse, la presente investigación plantea, en este contexto, la interrogante de si es posible encontrar las representaciones de la Iberoamérica neotomista y la 
Angloamérica empirista en la literatura del derecho de gentes en pleno siglo XIX. En este esquema, se sostendrá que Silva Santisteban es representante de la primera corriente, al basarse este en el sostenimiento de la tesis de la existencia del derecho internacional y que Bello, al negar la existencia del derecho internacional, puede ser entendido como representante de la escuela empirista. Esta hipótesis se construirá a partir de las obras centrales de ambos autores que son, respectivamente, Curso de derecho internacional o de gentes y Principios del Derecho Internacional.

\section{NEGACIÓN Y AFIRMACIÓN DEL DERECHO DE GENTES}

Usualmente, se considera como fecha de inicio del derecho internacional al siglo XVII, con los tratados de la Paz de Westfalia ${ }^{1}$. Y esto se debe a que tales tratados representan un momento clave porque el Estado moderno se libera de dos factores de presión que le restaban protagonismo. Por un lado, y desde un punto de vista externo al Estado, el Imperio y la Iglesia Católica se ven desmejorados en su posición de poder con la entrada en vigor de tales tratados; por otro lado, y desde un punto de vista interno, el feudalismo se va desplazando ante la solidez estructural de la recaudación tributaria del Estado (Clapham 2012: pp. 2-7; Flórez 1999: pp. 119-122).

Pero no siempre hubo una aceptación unánime de la esencia jurídica del derecho internacional. En ese contexto, uno de los puntos preliminares a resolver en el presente trabajo para abordar las posturas de Silva Santisteban y Bello es determinar el quid del debate relativo a la negación o afirmación del derecho internacional: ¿qué se niega o qué se afirma en torno al derecho

Los tratados de la Paz de Westfalia fueron celebrados en 1648, en las ciudades de Osnabrück y Münster, para darle fin a la Guerra de los Treinta Años. El primer tratado fue celebrado entre Suecia, por un lado, y, por otro lado, el Sacro Imperio Romano Germánico. El segundo tratado tuvo como partes a Francia y al referido imperio. Es preciso entender, en este punto, que sostener que tales tratados dan origen al derecho internacional es una consideración historiográfica de los iusinternacionalistas, por lo que no significa que el Estado moderno haya surgido a partir de tales tratados. (Neff 2014: pp. $139-141)$. 
de gentes? Walz advierte sobre la necesidad de la precisión en este punto para saber qué autores se encuentran dentro de una y otra categoría. Siguiendo su criterio, se puede entender que un negador del derecho internacional es aquel que no admite su juridicidad, comprendiéndose así a una serie de pensadores que tienen como punto en común "el excluir al llamado derecho internacional del reino de los valores jurídicos" (Walz 1943: p. 34).

Esta precisión inicial resulta ser de suma importancia porque el criterio walziano no asume que un negador no reconozca "la existencia del complejo normativo constituido por el derecho internacional", sino que su negación reside en descartar "simplemente el carácter jurídico de este complejo de normas" (Walz 1943: p. 35). Este matiz es fundamental porque como veremos luego, Bello no niega la presencia de normas en el derecho de gentes, sino que no les reconoce, realmente, fuerza jurídica. Este elemento se agrava aún más si se tiene en mente que el libro Principios de Derecho Internacional fue considerada "la primera obra científica de una utilidad general é [sic] incuestionable, que se ha dado á [sic] luz en la América Española"2 (Bello 1873: p. 5).

En tanto que la finalidad del presente trabajo es comparar las posturas de Silva Santisteban y Bello como ejemplos en nuestra región, respectivamente, de un defensor del derecho de gentes y un negador del mismo, será preciso presentar quiénes los precedieron en este debate. En ese sentido, aunque se parte de la identificación de Francisco de Vitoria ${ }^{3}$ y de Hobbes como ejemplos respectivamente de la opción ibérica y opción inglesa en el sentido morsiano, también pueden ser considerados representantes de la dicotomía generada entre la defensa y negación del derecho internacional. En este punto, se analizarán a estos autores en la lógica de la defensa y cuestionamiento del derecho internacional $\mathrm{y}$, en la siguiente sección, la configuración de la opción ibérica y la opción inglesa, desde la visión de Morse y los aportes de Becker Lorca.

\footnotetext{
2 Esta afirmación aparece en la nota del libro de Bello y que fuera escrito por Antonio José de Irisarri, bajo el título de "Advertencia".

3 Francisco de Vitoria (1483 - 1546) fue un fraile dominico, de origen español, considerado el mayor representante de la Escuela de Salamanca (Brett 2012).
} 
Francisco de Vitoria es, innegablemente, el padre del derecho internacional ${ }^{4}$, conjuntamente con Grocio. La paternidad del primero reside, esencialmente, en dos grandes obras que son la Relectio des indis y la Relectio de potestate civili $i^{5}$, aunque ninguno de estos escritos constituyan propiamente una sistematización del derecho internacional (Gómez Robledo 1989: p. 114; Anghie 1996: p. 321).

La primera es una obra en la que Vitoria busca justificar la empresa de colonización de la Corona Española en las nuevas Indias, enfrentándose, fundamentalmente, a dos tesis sostenidas en su época, a las cuales se recurría con el mismo propósito. Por un lado, a la autoridad del Papa y, por otro lado, a la idea del ius inventionis. La primera la rechazó con base en el argumento que los indios, lejanos geográficamente de Europa, no conocían la fe cristiana y, por ello, no era posible utilizar esta autoridad como posible elemento de justificación ${ }^{6}$. La segunda tampoco la admitió, debido a que no consideraba que los nuevos parajes fueran tierras sin dueño ${ }^{7}$, como se sostenía con el ius inventionis, por el cual se postulaba que las tierras descubiertas eran res nullius.

Esta labor de encontrar la causa justa de la conquista española es una de las razones por las cuales a Vitoria se le confiere el título de padre de derecho internacional, puesto que admite la posibilidad de un relacionamiento político y comercial más allá de Europa con otras entidades políticas que, más adelante, conformarían también la comunidad del totius orbis, idea desarrollada con maestría en la Relectio de potestate civili, bajo los siguientes términos:

$4 \quad$ También ha recibido el apelativo de "padre del derecho colonial moderno" (Iannarone 1970: p. 5).

5 Gómez Robledo agrega la Relectio de temperantia como uno de esos textos fundantes; sin embargo, el análisis que realiza el profesor mexicano se centra en un fragmento de esta relección vitoriana que se critica en su autenticidad (1989: p. 22). Iannarone ha considerado esta Relectio como un texto antecesor al de Relectio des indis (1970: p. 18).

6 Como señala Vitoria, “[...] no tienen por qué acatar la sentencia del Papa quienes no sean cristianos, pues que por ningún otro título puede el Papa condenar o castigar, si no es por el de ser Vicario de Cristo" (1975: p. 82).

7 En tal sentido, Vitoria sostiene que "[e]s de derecho de gentes que se concedan al ocupante las cosas que no son de nadie (...); pero como aquellos bienes no carecían de dueño, no pueden ser comprendidos por este título" (1975: p. 69). 
"Que el derecho de gentes no solo tiene fuerza por el pacto o acuerdo entre los hombres, sino que tiene fuerza de ley. En efecto, el orbe todo, que en cierto modo constituye una única república, tiene el poder de promulgar leyes justas y convenientes para todos, cuales son las del derecho de gentes. De donde se sigue que pecan mortalmente quienes violan el derecho de gentes, ya sea en la paz o en la guerra, o en los asuntos más graves, como es el no respetar a los legados. No le es lícito a un reino particular no querer atenerse al derecho de gentes, ya que ha sido promulgado por la autoridad del orbe entero" (Vitoria 2008: p. 63)

Este párrafo inscrito en el punto 21 de la citada Relectio, con el título "Si las leyes civiles obligan a los legisladores y, en máximo grado, a los reyes. Vigencia del Derecho de gentes", ha sido considerado por autores de la talla de Gómez Robledo (1989: pp. 32-33) y Miaja de la Muela (1965: p. 355) como un pasaje clave para la comprensión del pensamiento vitoriano. Es a partir de este texto que se puede sostener que Vitoria reconoce que el derecho de gentes es uno que tiene carácter jurídico ("fuerza de ley") y que, además, debe ser respetado en todo el orbe. Esta inspiración, si bien inscrita en el marco de la lógica del derecho natural, resulta ser la pieza clave bajo la cual se construirá, posteriormente, el pensamiento de Grocio quien también defenderá el carácter jurídico y aplicable del derecho internacional.

En contra de esta posición que defiende el ethos jurídico del derecho internacional, se encuentra una serie de autores, de los cuales hemos escogido a Hobbes 8 , que puede ser apreciado como "el primero que en la doctrina haya negado seriamente el carácter jurídico del derecho internacional" (Walz 1943: p. 39; en la misma línea, Truyol y Serra, 1998: pp. 86-87), cuyo pensamiento se resume en "El Leviatán" (1651) y cuyas premisas son compatibles con las de otros negadores importantes del derecho internacional, como Austin ${ }^{10}$, en el sentido que el primero sostendrá que, dada la ausencia de un gobierno internacional, no sería posible afirmar que el derecho internacional sea, realmente, Derecho (Orakhelashvili 2011: p. 8).

$8 \quad$ A Hobbes $(1588$ - 1679) se le considera, junto con John Locke, como uno de los pensadores ingleses más importantes del siglo XVII (José Contreras 2016: p. 169). Para efectos del presente trabajo se ha revisado la edición en inglés de Oxford, a cargo de Gaskin (1998).

10 Según Austin, el derecho internacional carece de las características del derecho 
Hobbes distingue entre un "estado de naturaleza", caracterizado por un status quo de enfrentamiento total ("bellum omnium contra omnes") ", y "un estado de sociedad". Para superar el primer estado de cosas, que es una situación completa de anomia de carácter hipotético (no necesariamente histórico), y llegar al segundo estado, es fundamental un contrato social. En ese sentido, Hobbes es, al igual que Locke y Rousseau, un teórico del contrato social (José Contreras 2016: p. 170), solo que sostendrá, a diferencia de estos filósofos, la preexistencia de un "estado de naturaleza" caótico, al cual lo denominará "guerra" (Hobbes 1998: p. 84), no en el entendido de un enfrentamiento bélico, sino en la "disposición manifiesta a ella durante todo el tiempo en que no existe seguridad de lo contrario"12. En ese sentido, Hobbes no comparte la idea de sociabilidad ${ }^{13}$ que sostiene Aristóteles, concepto clave en el pensamiento vitoriano.

De un escenario como el del "estado de naturaleza", se denegará, no solo la premisa aristotélica de la sociabilidad, sino sobre todo la posibilidad de la justicia. Por ello, sostendrá que "[d]e esta guerra de todos contra todos se sigue $[\ldots]$ que nada puede ser injusto. [...] Donde no hay poder común, no hay ley; donde no hay ley, no hay injusticia"14 (Hobbes 1998: p. 85).

positivo, porque sus normas no son establecidas por un poder supremo y porque estas no tienen el carácter de mandato (Murphy 2012, p. 6; Walz 1943: p. 119).

11 Hobbes utiliza la expresión "as is of every man, against every man" (1998: p. 84).

12 En este punto, Hobbes señala "known disposition thereto, during all the time there is no assurance to the contrary" (1998: 84).

13 La sociabilidad aristotélica se sustenta en el libro "Politeia" (Política), en el cual el Estagirita sostiene que "[...] la polis existe en la naturaleza, y que el hombre es por naturaleza un animal político. Quien, pues, por su naturaleza - y no por accidente[carece] de polis es o un loco, o un [ser] superior, o un individuo como [aquel] a quien condena Homero, [como alguien] sin familia, sin ley y sin hogar" (Aristóteles 1989: pp. 135 - 136). A esta apreciación de la naturaleza humana, Hobbes se opondrá a partir de la tesis Homō hominī lupus est, que no comienza con "El Leviatán", sino con una obra anterior del mismo autor inglés, "De Cive". En efecto en este último libro, Hobbes señala "To speak impartially, both sayings are very true; That Man to Man is a kind of God; and that Man to Man is an arrant Wolfe" (1987: p. 24).

$14 \quad$ En su version en inglés, se afirma lo siguiente: "To this war of every man against every man, this also is that nothing can be unjust. The notions of right and nothing is wrong, justice and injustice have there no place. Where there is no common power, there is no law: where no law, no injustice." 
Si bien Hobbes no aporta ninguna teoría profunda sobre el derecho internacional, en la línea de esta premisa de negación del derecho y de la justicia, llegará a sostener lo siguiente:

"Con respecto a los cargos de un soberano a otro, que están comprendidos en esa ley, que comúnmente se llama la ley de las naciones, no necesito decir nada en este lugar; porque la ley de las naciones y la ley de la naturaleza es lo mismo. Y cada soberano tiene el mismo derecho, de procurar la seguridad de su pueblo, que cualquier hombre en particular puede tener, de procurar su propia seguridad. Y la misma ley, que dicta a los hombres que no tienen un gobierno civil, lo que deben hacer y lo que deben evitarse unos a otros, dicta lo mismo a las comunidades, es decir, a las conciencias de los príncipes soberanos y las asambleas soberanas." 15 (Hobbes 1998: p. 235)

Asumiendo la identificación del derecho de gentes con el derecho natural, Hobbes tiene como postura que cada Estado debe buscar protegerse a sí mismo, puesto que no existe para él una autoridad por encima de los Estados que brinde esa seguridad y que, por lo tanto, pueda fundamentar el derecho internacional positivo.

En este último detalle veremos, posteriormente, una conexión entre la postura de Bello con la de Hobbes, porque este autor es el primero en sostener que la preocupación de cada ser humano y, del mismo modo, de cada sociedad, es la de su propio bienestar. En ese sentido, no solo ofrece una negación del derecho internacional, sino que reconoce que la manera cómo se desenvuelven los Estados en el escenario internacional es buscando un aumento de su poder (Walz 1943: p. 47).

15 La version original de la cita dice lo siguiente: "Concerning the offices of one sovereign to another, which are comprehended in that law, which is commonly called the law of nations, I need not say anything in this place; because the law of nations, and the law of nature, is the same thing. And every sovereign hath the same right, in procuring the safety of his people, that any particular man can have, in procuring his own safety. And the same law, that dictateth to men that have no civil government, what they ought to do, and what to avoid in regard of one another, dictateth the same to commonwealths, that is, to the consciences of sovereign princes and sovereign assemblies.” (Hobbes 1998: p. 235) 
Otro autor importante a tomar en cuenta, para comprender a Bello, es Jeremy Bentham, famoso pensador considerado padre del utilitarismo inglés. Este filósofo sostendría que la ley es susceptible de ser modificada y que, en ese camino, debe generar el máximo nivel de felicidad para la cantidad más amplia de personas. Si bien se inclinaría por aceptar la prevalencia del interés público por sobre el interés privado, no reconocería la existencia de los derechos naturales y se opondría, por ello, a la Déclaration des droits de l'homme (1789) pronunciada en la Revolución Francesa, al considerarla como un terrible invento metafísico (Reale, G.; Antiseri, D.; 1988: pp. 286288). Respecto al derecho internacional, Bentham argüía que la fuerza de un tratado entre dos naciones es menor al vigor de un contrato entre dos individuos, lo cual demuestra su inclinación por minusvalorar el valor jurídico del derecho de gentes (Orakhelashvili 2011: p. 10).

Antes de ingresar a examinar las posturas de Santisteban y de Bello, entraremos a ofrecer un marco teórico que permita discurrir mejor en la discusión que se ha pretendido plantear aquí.

\section{LA ERA DECIMONÓNICAY EL DERECHO DE GENTES A LA LUZ DE LA POSTURA DE MORSE}

El siglo XIX es un periodo de la historia del derecho de gentes que se caracteriza, a diferencia de los siglos anteriores, por experimentar la universalización del derecho internacional, discutiéndose básicamente dos tesis de cómo se produjo tal universalización (Becker Lorca 2010: pp. 475-477) ${ }^{16}$ : La primera tesis, que podemos llamar tradicionalista, sostiene que tal universalización es producto de la expansión del ius publicum europeum, que se desarrolló desde el siglo XVII con los tratados de la Paz

16 Esta universalización tiene su explicación en las características del siglo XIX, donde la movilidad humana y del capital se dio como nunca antes en la historia. Como destaca Osterhammel, "[t]oda la historia [del siglo XIX] desborda de movimiento: viajes, pueblos que migran, campañas militares, comercio con lugares remotos, difusión de religiones, lenguajes y estilos artísticos". Asimismo, señala que el "capital fluyó por todo el globo impulsado en particular por la instalación de múltiples redes ferroviarias, más que por la economía fabril” (2015: pp. 1274 - 1275). 
de Westfalia, así como de la superposición de esta versión del derecho internacional sobre las otras versiones posibles de este en otros lugares del orbe. La segunda tesis se distancia de la anterior, planteando que tal universalización no supuso un proceso de simple recepción del derecho internacional desarrollado por Europa, sino una asimilación estratégica de sus instituciones y su replanteamiento por las potencias extraeuropeas en pro de sus intereses nacionales, entre las cuales destacan las de Hispanoamérica, recién independizadas.

En el primer caso, la tesis tradicionalista es una que parte de una construcción desigual de las relaciones internacionales, en la que las potencias europeas se presentan como aquellas que ostentan un mayor nivel de civilización, frente a las realidades extraeuropeas, a las que se les concibe como primitivas, salvo ciertas excepciones ${ }^{17}$ (Cassese 2013: pp. 34-37). En cambio, la tesis cuestionadora se inclina por concebir a tales potencias fuera de Europa como capaces de asimilar, deconstruir y replantear, hasta cierto punto, el derecho internacional recibido.

Ante ambas posiciones, existen razones para inclinarse por la tesis cuestionadora. En primer lugar, la tesis tradicionalista estudia el proceso desde Europa y, por ello, bajo los intereses historiográficos europeos. Esto puede implicar una distorsión en la comprensión de las realidades de las Américas porque no se percibe a las potencias hispanoamericanas bajo un rol activo o simplemente se les ignora. La tesis tradicional, en segundo lugar, omite por desinformación lo que ocurre en las latitudes extraeuropeas y también desconoce que, fuera de Europa, hubo también producción literaria en derecho internacional.

El presente estudio parte de aceptar la tesis cuestionadora porque no se puede apreciar, en su verdadera dimensión, las contribuciones de dos autores como Silva Santisteban y Bello, si se sigue asumiendo la tesis tradicional que se limita a los aportes de pensadores que hayan nacido

$17 \quad$ En el marco del derecho internacional clásico, las relaciones con las potencias extraeuropeas se construían de dos maneras. Por un lado, se celebra capitulaciones con potencias orientales y asiáticas. Por otro lado, a aquellas estructuras que no se les consideraba, desde la óptica europea, suficientemente evolucionadas, se les colonizaba (Cassese 2013: pp. 34-37). 
en Europa o que hayan producido su bibliografía en esas latitudes. Aquí, igualmente, cabe precisar un matiz. No se trata de rechazar el hecho que, durante el siglo XIX, Europa haya influido en las concepciones de los ius internacionalistas locales; por el contrario, al igual que con Morse, se coincide en que la tradición del pensamiento europeo se transmite o se traslada, pero este es el telón de fondo del cual se parte, sin que ello agote la riqueza inventiva de los pensadores del derecho de gentes en nuestro continente. Concebir que se produjo solo la recepción de las teorías europeas del derecho internacional es, básicamente, caer en el error de sobrevalorar lo europeo e infravalorar los aportes extraeuropeos y, en este caso, de la América Hispánica.

Este proceso de replanteamiento o reacomodo de la herencia cultural recibida, sin que ello implique propiamente una innovación completa o un olvido de todo el tesoro cultural prefabricado, es uno que se puede percibir en varias de las contribuciones de los autores del derecho de gentes de la época. Son ellos los principales artífices de esta labor de asunción del ius publicum europeum y también los que empiezan a remodelar esta herencia desde su visión periférica.

Es bajo este esquema que, cada vez más, se vuelve necesaria la búsqueda de ius internacionalistas decimonónicos en nuestra región, por razones de índole científica e histórica, porque la falta de estudios sobre esta materia es un perjuicio a los orígenes regionales del derecho de gentes. Por una parte, porque es una etapa muy poco estudiada en general y de la que se llega a asumir automáticamente la posición eurocéntrica, cuando es posible también percibir que los actores periféricos y semiperiféricos no son para nada pasivos ante el tesoro cultural heredado. Por ello, resulta de sumo interesante saber cómo es que, en la realidad hispanoamericana, es posible sostener tal papel activo de los autores locales de derecho de gentes (Becker Lorca 2010: pp. 477-479).

En la construcción de ese papel activo, es preciso indicar que la reacción de los autores que estudiaron el derecho de gentes no tuvieron necesariamente las mismas visiones, sino que intentaron construir sus propias posturas. Esto se debe a que, frente a un mismo fenómeno, nunca existe una sola aproximación: es más que probable que cada autor pudiera tener una 
visión que contara, más allá de puntos en común, con particularidades que los caracterizaron y que merecen ser estudiadas.

Justamente, para resolver el cuestionamiento trazado en esta investigación es necesario acudir al planteamiento de Morse en su obra magna $O$ espelho de Próspero: cultura e idéias nas Américas (1988). Este libro llama la atención de que el siglo XIX no comenzó sin una etapa de formación previa, por lo que para la explicación de cómo es que se ha llegado a la exportación del derecho de gentes y su asimilación/cuestionamiento en nuestra región, es necesario verificar, a grandes rasgos, los pasos que preceden a este siglo; más aún si se busca entender cómo es que los autores del derecho de gentes no reaccionaban necesariamente de la misma manera ante un universo jurídico todavía novísimo para su propia realidad.

Morse sostiene que existió, antes de su separación, una matriz cultural e intelectual común de origen europeo entre Hispanoamérica y Angloamérica (1988: p. 22). Esta etapa se inició para este pensador en el siglo XII y evolucionó hasta el siglo XVII, produciéndose progresivamente una bifurcación de tradiciones que darán la impronta de los pensamientos filosóficos, jurídicos y políticos de estas dos realidades. Pero como advierte este autor, no fueron modelos herméticos, ni realidades que carecieran de contradicciones internas (Morse 1988: p. 22).

La diferencia entre la opción hispánica del siglo XVI, que influirá con mayor fuerza en Hispanoamérica, y la opción inglesa, cuyo acervo se transmitirá en el siglo XVII a Angloamérica, puede graficarse en las diferencias respectivas de dos autores clásicos como Francisco de Vitoria y Thomas Hobbes (Morse 1988: pp. 60-63).

Morse anota algunas diferencias notorias en las posiciones de ambos pensadores, de las cuales cabe resaltar aquí algunas. Para el caso de Vitoria, este se dedicó a analizar las justificaciones de la expansión del imperio español y la colonización de las Indias en el marco, principalmente, del derecho natural (Anghie 1996: pp-323-327); en cambio, Hobbes buscó, sobre todo, la reconstrucción de su propia sociedad para contrarrestar su caos originario. Mientras que Vitoria procuró un esquema pensado en abstracto, en una sociedad común o general, Hobbes se inclinó por una sociedad en la que prima lo particular o individual. Siguiendo esta inclinación por la 
colectividad en el pensamiento vitoriano, el gran representante de la Escuela de Salamanca prefirió construir una teoría política del bien común; en cambio, Hobbes se manifestó a favor de un Estado que pudiera garantizar los derechos y libertades de cada ciudadano.

Ya para el siglo en que se celebró la Paz de Westfalia, se habrían configurado las dos tradiciones diferenciadas y que podemos ver como tipos ideales, en la terminología weberiana ${ }^{18}$. Pero aquí debemos precisar que, una vez diferenciadas las tradiciones hispánica e inglesa, en el siglo XIX, estas van a desembocar en una mixtura que se alejará de la diferenciación notoria que podemos hallar en Vitoria y Hobbes. De la tradición común en el siglo XII se pasó, entonces, al distanciamiento en el siglo XVII y luego, una vez separadas, a un acercamiento que terminará en una mixtura de enfoques en pleno siglo XIX. De este modo, en la propia Hispanoamérica va a ser posible encontrar un panorama que ya no se cierra a una visión únicamente vitoriana o iusnaturalista, sino también va a observarse la presencia de la otra tradición empirista que se va introduciendo y que va siendo parte del repertorio ideológico de ciertos pensadores.

Y es aquí donde se debe resaltar la presencia de los dos grandes autores que se pretenden estudiar. Silva Santisteban y Bello son hispanoamericanos, uno de nacionalidad peruana y el otro venezolano, respectivamente, pero entre ellos no es posible encontrar una suerte de "vitorianismo puro". Por el contrario, se perciben ciertos distanciamientos o reparos con el propio iusnaturalismo, de manera mucho más notoria en la obra de Bello.

18 Weber en La ética protestante y el espíritu del capitalismo ha utilizado la noción del tipo ideal cuando trata de explicar los rasgos del calvinismo, el pietismo, el metodismo y el movimiento baptista. En ese contexto, señala que, en su obra, se exponen "las ideas religiosas en una estructura de «tipo ideal» que rara vez se da en la realidad. Pues, precisamente porque es imposible trazar fronteras claras en la realidad histórica, sólo podemos esperar dar con sus efectos específicos investigando sus formas más estructuradas." (2016: p. 143). El tipo ideal sería, entonces, una unidad modélica que se contrasta con la realidad, destinada a explicar un determinado fenómeno histórico (Sánchez de Puerta Trujillo 2006: pp. 15 - 19). 
Este artículo pretende encontrar, en los aportes de las principales obras de estos grandes autores de nuestra región, qué tanto es posible partir de la tesis de Morse para explicar la diferenciación de sus obras en la lógica de las tradiciones neotomista, para efectos de entender a Silva Santisteban, y empírica, en el caso de Bello. Comenzaremos, a continuación, explicando el planteamiento del primero.

\subsection{La concepción de Silva Santisteban sobre derecho de gentes}

José Silva Santisteban ha sido considerado como uno de los primeros principales internacionalistas peruanos en el siglo XIX (Basadre Ayulo 2001: p. 474), a quien luego le seguiría Pablo Pradier-Fodéré y Carlos Wiesse en importancia. La obra del primero en materia de derecho internacional público, y que ha quedado para la posteridad, es la del Curso de derecho internacional o de gentes ${ }^{19}$, a la cual el propio autor califica de un "curso sencillo y metódico" 20 (1858: p. 43), cuyo propósito se destina a una comprensión del derecho de gentes, desde la filosofía y la historia de esta rama (Silva Santisteban 1858: pp. 19 - 20), debiéndose esta doble percepción a que “(...) al lado de la historia de los hechos, deberá ir la de la ciencia, para conocer su marcha progresiva, en armonía con el desarrollo de las instituciones" (1858: p. 20). En el fondo, Silva Santisteban quiere lograr la presentación del derecho de gentes desde una mirada científica de la misma y esta es la clave que explica todo el libro. Por eso, llega a afirmar que la "(...) ciencia de Grocio (...) no se halla elevada aún a la altura de verdadera ciencia” (1858: p. 42).

Con el propósito de entender la concepción de Silva Santisteban, y bajo la lógica del debate planteado entre afirmadores y negadores del derecho internacional, en este acápite se estudiará su noción de derecho de

19 Basadre Ayulo destaca también de este autor el libro Derecho peruano. Parte Civil de 1853 (2001: p. 475).

20 El libro de Silva Santisteban (1858) se compone de una introducción (pp. 19-20); un primer período (21-28) y un segundo período (pp. 29-46) en la evolución del Derecho de gentes; una parte general, titulada "Ciencia" (pp. 47 - 72); y dos partes especiales referidas al derecho positivo; la primera titulada "De las naciones consideradas en su estado normal o de paz" (pp. 73 - 164), y la segunda "De las naciones en un estado anormal o de guerra (pp. $165-221)$. 
gentes y los fundamentos filosóficos de los cuales parte. Este análisis es uno que no pretende agotar toda la sabiduría expuesta por el profesor peruano, sino que busca presentar elementos que permitan visualizar la tesis de Morse para efectos de la evolución del derecho de gentes en el siglo XIX.

Silva Santisteban (1858: p. 57) define al derecho internacional, del modo siguiente:

"la ciencia que trata de arreglar las relaciones internacionales según los principios eternos de justicia, o en otros términos, establecer los principios a que deben sujetarse las naciones en la prestación de medios externos necesarios para alcanzar sus fines racionales" ${ }^{21}$.

Resulta bastante interesante que este autor califique al derecho internacional como ciencia, destacando de manera muy evidente el atributo racional que esta rama del derecho tendría. Como desmiente Morse (1988: p. 34 - 36), la postura neotomista nunca cuestionó la cientificidad del conocimiento, por el contrario, resistió a aquellos autores que introducían los planteamientos conjeturales o probabilísticos. Esta tesis responde, en el fondo, al intento de aquel profesor peruano de sostener el carácter científico del derecho internacional, haciendo frente a la postura empírica, que negaba tal estatus. En efecto, critica a "los que se limitan a exponer los usos actuales y juzgan que no existe un derecho de gentes, porque no hay leyes impuestas a las naciones ni autoridad superior de donde emanen, [confundiendo] el fondo con la forma, [pretendiendo] resolver cuestiones de alta filosofía con las ideas vulgares y empíricas de derecho" (Silva Santisteban 1858: 57).

$21 \quad$ Actualmente, la cuestión relativa a la definición del derecho internacional no es que se encuentre resuelta (Rosales Zamora 2018: pp. 16-21), pero es importante aquí hacer mención a que autores del prestigio de Daillier, Forteau y Pellet han preferido definir al derecho internacional como derecho aplicable a la sociedad internacional (2009: p. 43). Esta definición busca no solo responder al principio básico ubi societas, ibi ius, sino sostener que el derecho internacional es, como tal, un sistema jurídico, evitando así una construcción conceptual que limite materialmente tanto los elementos de ese derecho -evitando dar una respuesta definitiva a si este derecho comprende solo a las normas y no a los principios, si este derecho puede tener manifestaciones no mandatorias como el soft law, entre otras cuestiones-, así como la posibilidad de la aparición de nuevos sujetos de derecho internacional. 
En ese sentido, el profesor peruano abraza el racionalismo y concibe como el peor enemigo del cuestionamiento de la cientificidad del derecho internacional al empirismo. Pero aquí, al inclinarse por el racionalismo es que Silva Santisteban está llevando el debate al punto explorado por Morse, puesto que este uso de la razón que pregona en el carácter científico del derecho de gentes es uno que se orienta por los "principios eternos de justicia", lo cual revela una influencia neotomista que se trasluce en la idea de la "existencia del principio que debe presidir en las relaciones internacionales, o de una ley de las naciones, [que] se deduce pues lógicamente de la naturaleza misma de la nación" "22 (Silva Santisteban 1858: p. 55).

Uniendo ambos elementos, es posible entender que Silva Santisteban sea un iusnaturalista racionalista - superando a Vitoria, pero no alejándose de este -, que pretende sostener que, más allá del caos de las relaciones internacionales, existen principios que trascienden la voluntad de las naciones. Y que es intrínseco a esta unidad política que no se aísle, sino que se relacione, en virtud del principio de sociabilidad, el cual supone el estrechamiento de las relaciones exteriores con las otras naciones, para configurar "en una sola familia la humanidad entera" (Silva Santisteban 1858: p. 54).

Este iusnaturalismo racionalista es uno que descansa en la admiración del autor por Grocio, al cual lo concibe como verdadero científico del derecho internacional. Y este punto es trascendental porque Grocio es continuador de Vitoria, como lo sostiene el profesor mexicano Gómez Robledo (1989: 101 y ss.), al tratar de resolver el dilema relativo de quién de los dos es padre del derecho internacional. Y la respuesta del tratadista mexicano es de una sabiduría admirable porque encuentra que ambos lo son, sin desmerecer sus aportes, solo que el descubridor es Vitoria con sus ideas del totius orbis y del ius communicationis, correspondiéndole a Grocio el papel de sistematizador

22 Aquí debe precisarse que este autor utiliza el término "nación" para referirse a lo que actualmente el derecho internacional concibe como Estado, cuando sostiene que el término designa a una "comunidad de origen o nacimiento, de donde resulta que a los individuos de una raza, a los descendientes de un padre común, se les califica de esta manera" y cuyo "principio dominante es la unidad política, y no solo intrínseca sino representativa, es decir, que la nación sea representada como una unidad en sus relaciones con las demás" (Silva Santisteban 1858: p. 53). 
de este último principio en el famoso Mare liberum. Así lo admite Van der Vlugt, como cita Gómez Robledo, al sostener el primero que "[e]ste opúsculo no tiene otro valor que el de un estudio bien hecho de segunda mano, importado de la sabiduría española" (1989: p. 113).

Sintiéndose heredero de Grocio, Silva Santisteban es sino un continuador de Vitoria, y con ello hace suyo el planteamiento iusnaturalista del neotomismo en la explicación del enfoque morsiano, rechazando la visión empirista que desciende en un utilitarismo, como veremos con el desarrollo de las ideas de Andrés Bello.

\subsection{Andrés Bello y Principios del Derecho Internacional}

Este personaje no excepto de controversia ha sido considerado, no obstante, como uno de los mayores intelectuales del siglo XIX en las Américas $^{23}$. De origen caraqueño, estudió Derecho en Londres y se encargó de ordenar los manuscritos del mayor representante del utilitarismo, Jeremy Bentham, a quien conoció personalmente (Otero Parga 2017: p. 86). Ocupó luego diversos cargos públicos, entre los cuales destacó el puesto de oficial mayor del Ministerio de Hacienda de Chile (1834) y el cargo de senador de la República (1832 a 1864). De una actividad intelectual muy prolífica, Bello regentó el Colegio de Santiago hasta 1832; cuando esta institución se clausuró, Bello se dedicó a brindar, en su casa, lecciones de diversas materias, entre las cuales precísase mencionar la de derecho de gentes. De 1843, en adelante, dirigiría, en calidad de rector, la Universidad de Chile hasta su muerte (Olano García 2007: pp. 70 - 72).

La obra cumbre de Bello en el terreno del derecho internacional fue el famoso libro Principios de derecho internacional ${ }^{24}$, que, originalmente, se denominó Principios del derecho de gentes, en su primera publicación de 1832. Este texto alcanzará un gran éxito a nivel de la región en el siglo XIX por

\footnotetext{
23 Como opina Otero Parga, "sabemos también que Bello estudió en profundidad latín y que tuvo una cultura muy [v] asta para su tiempo." (2017: p. 94).

$24 \quad$ La obra Principios de Derecho Internacional se compone de unas "Nociones preliminares" (pp. 19 - 22) y de tres partes, referidas al estado de paz (pp. 23-146), estado de guerra (pp. 147-304) y los derechos y funciones de los agentes diplomáticos (pp. 305 al 323).
} 
el esfuerzo desplegado por Bello de leer, en palabras de un exaltado Antonio José de Irisarri, "[...] todos los libros que deben componer la biblioteca del hombre que quiere conocer á [sic] fondo el derecho internacional"25.

En las "Nociones preliminares" de su obra, es que Bello desarrollará la noción de derecho de gentes, bajo la definición de "colección de las leyes ó [sic] reglas generales de conducta que las naciones ó [sic] Estados deben observar entre sí para su seguridad y bienestar común" (1873: p.11).

Debe llamarse, especialmente, la atención sobre esta definición propuesta y que se mantiene a lo largo de las reediciones del libro citado, porque esta es una de las principales razones para considerar a Bello como un negador del derecho internacional. Define al derecho de gentes como una "colección", que podría entenderse en el sentido de "un conjunto ordenado de cosas, por lo común de una misma clase y reunidas por su especial interés y valor" ${ }^{26}$. Este carácter de conjunto que propone Bello supone una mirada específica del derecho de gentes, no en el sentido de que conforme un sistema jurídico cohesionado, sino que configuraría un simple listado de reglas. Ante ello, debe recordarse que se erige una evidente distancia entre señalar que es una rama del Derecho o un sistema jurídico, a afirmar, simplemente, que es una colección de leyes o reglas generales de conducta.

Este elemento de apreciar al derecho internacional como una colección supone que Bello concebía al derecho de gentes, no tanto desde una preocupación científica, sino más bien como una arista más del saber. Recuérdese que el intelectual caraqueño fue un humanista que se inclinó por más de una rama del conocimiento y creo que, por muy sabia y cara que haya sido la construcción de su libro, esta también recibe el influjo de su tiempo y, más aún, el proceso de formación de su autor.

Un segundo elemento a tomar en cuenta es que Bello no solo opta por inclinarse a definir el derecho de gentes como una colección, sino que es una colección de leyes o reglas generales, presentando con ello una inclinación o

25 Como se ha hecho notar, anteriormente, esta afirmación pertenece a Antonio José de Irisarri, y se encuentra en el libro de Bello que trabajamos aquí, bajo el título de "Advertencia".

26 Esta es la definición de colección, en su primera acepción, que da el Diccionario de la lengua española. 
preferencia por una lectura positivista del Derecho. En ese sentido, también indica, en este capítulo que "[...] las reglas establecidas por la razón ó [sic] por el consentimiento mutuo, son las únicas que sirven, $[\ldots]$ para el ajuste de las diferencias entre soberanos" (Bello 1873: p. 19).

En ese sentido, reconoce un derecho de gentes natural, que vendría a ser el que surge de la razón; y un derecho de gentes positivo, que es el convencional, sea expreso o tácito, y "cuya fuerza solo se deriva mediatamente de la razón, que prescribe á [sic] las naciones, como regla de importancia suprema, la inviolabilidad de los pactos" (Bello 1873: p. 16). Sea uno u otro tipo de Derecho lo entiende ligado, siempre, a la razón.

Pero este racionalismo lo lleva a un sendero distinto que al de Silva Santisteban, dado que Bello afirmará que "[n]o hay un código en que estén recopilados los preceptos o prohibiciones del Derecho internacional, sea natural, sea instituido, lo que produce incertidumbres y dudas, que los Estados poderosos no dejan nunca de interpretar a su favor" (1873: p. 19). Esta es una lectura que demuestra la clara noción del autor por un reconocimiento del estado de guerra hobbesiano al emplear una lectura de las relaciones internacionales desde el poder.

En ese sentido, es importante comprender que hay un nexo fundamental entre la concepción del derecho de gentes como colección con la formación londinense de Bello, instrucción que, como se mencionó hace unas líneas atrás, fue en Derecho. En ese sentido, Bello había bebido directamente del espíritu empirista inglés y más aún debe haber sentido una especial cercanía a la obra de Bentham, porque de otra forma, no se hubiera dedicado a ordenar su obra. En ese sentido, Bello ha debido conocer el derecho internacional bajo el influjo del espíritu empirista y utilitarista, lo cual refuerza la propuesta de abordaje que hemos presentado ${ }^{27}$.

27 Algunos autores se han inclinado en considerar a Bello como un pensador que recibió una fuerte influencia de Suárez, un importante pensador del derecho internacional y representante, al igual que Vitoria, de la Escuela de Salamanca (Otero Parga 2017: pp. 93-98). Se debe, gentilmente, discrepar de esta estimación. Si bien es más que probable que Bello haya conocido de la obra de pensadores de la talla de Grocio o de Suárez, esto no implica un real cambio en su concepción relativa a la definición de derecho internacional. Esta tesis se confirma con el hecho que a lo largo de las tres ediciones de su texto Principios de derecho internacional, el intelectual caraqueño no 
En suma, la definición de derecho de gentes por la que opta Bello demuestra encajar, en este terreno, con la presentación de la opción inglesa que propone el texto de Morse.

\section{CONTRASTE DE LAS POSTURAS DE SILVA SANTISTEBAN Y BELLO BAJO EL ESQUEMA DE MORSE}

Como se ha visto, el debate de los afirmadores y negadores del derecho internacional tiene también sus representantes a nivel de la literatura hispanoparlante, producida en nuestra región durante el siglo XIX. Si bien este debate in concreto no es planteado por Morse, este autor cuenta con una lucidez extraordinaria que permite explorar el encuentro de dos gigantes del derecho de gentes en nuestro continente, que son Silva Santisteban y Bello, los cuales además tienen el mérito de ser los primeros autores que tratan sobre la materia de un Derecho que va más allá de las fronteras, mostrándose, a su vez, como herederos de tradiciones ideológicas diferentes entre sí.

En efecto, lo que se sostiene es que tales herencias intelectuales son las que definen que uno y otro autor acepten o no la juridicidad del derecho internacional.

Morse ilustró los contrastes entre la opción hispánica y la opción inglesa en un sentido político e intelectual, como las grandes matrices en Europa que explicarán, posteriormente, las dinámicas intelectuales, políticas y económicas de las colonias hispánicas en nuestro continente, en el primer caso, y las colonias británicas, en el caso de Estados Unidos, así como de su gesta independiente y su posterior destino. Tales modelos no se encierran en sí mismos, sino que se esparcen y se entrelazan generando una serie de encuentros y desencuentros a nivel de las instituciones jurídicas, de las cuales cabe destacar aquí al concepto del propio derecho de gentes.

haya alterado el concepto de derecho internacional como listado de leyes, acercándose a la aproximación empirista y utilitarista que se ha identificado. 
Esta forma de concebir la política tiene consecuencias evidentes en la gestación y comprensión del Derecho ${ }^{28}$, lo que nos dará como resultado un punto esencial a considerar: las instituciones jurídicas en nuestro continente no son puras, sino que reciben herencias que entre sí pueden ser contradictorias. Mientras que, desde una opción hispánica, con toda la dote neotomista, el Derecho es uno que apunta hacia el bienestar social, que permite una cohesión entre sus componentes; la opción inglesa es una que se inclina por la supervivencia y, por ello, en la individualidad y el sentido pragmático del Derecho: las instituciones jurídicas sirven para los fines egoístas de los individuos, para su perduración.

En el presente artículo, se ha buscado examinar la definición del derecho de gentes desde las visiones de Silva Santisteban y Bello, ambas en calidad de punto de partida y muestra para examinar un debate de quienes sostienen la juridicidad de este Derecho, frente a aquellos que lo niegan, considerando también, como marco general, la tensión existente entre la opción hispánica e inglesa en la configuración de estos dos pensamientos distintos. En ese sentido, en el debate entre Silva Santisteban y Bello, es necesario tomar consideración, por un lado, de la construcción de Francisco de Vitoria, así como de su sucesor Grocio; y, por otro lado, la visión de Hobbes y Bentham, respectivamente.

En ese esquema, de la lectura atenta de los textos de Vitoria y Grocio, se puede identificar que para ellos existe un derecho de gentes universal que es capaz de exigir a todos sus componentes una debida obediencia por los valores que consagra. En cambio, la apreciación de las posturas de Hobbes y Bentham - pese a que este último fuera el que le diera nombre al derecho internacional (International law) (Rosales Zamora 2018: p. 17) no les importa que tal derecho de gentes goce de universalidad: su enfoque es más pragmático, porque no ven el interés social como primero, sino que privilegian la posición de los Estados en su individualidad. En ese sentido,

28 El adagio ubi societas, ibi ius (“donde hay sociedad, existe derecho") es fundamental aquí, dado que las características de una sociedad conducirán a la forja de las instituciones y nociones jurídicas, sin negar con ello, la precedencia de herencias históricas que moldean y que resultan ser puntos de partida en la elaboración de las normas o conceptos jurídicos. 
difícilmente conciben que los Estados acepten renunciar a su soberanía con facilidad por el bien común.

Debe recordarse que Silva Santisteban y Bello, siendo beneficiarios de todas estas herencias intelectuales, no son herederos pasivos, sino que son capaces de asimilar lo mejor de cada tradición y plantear relecturas desde una posición de consolidación de sus propios Estados, como lo llega a sostener Becker Lorca (2010: pp. 521-523). Recordemos, en ese sentido, que Silva Santisteban y Bello pertenecieron a Estados que habían surgido recientemente a la vida independiente y que buscaban sobrevivir a cualquier tipo de ofensiva de las potencias coloniales ${ }^{29}$.

Luego de la revisión de las posturas de Silva Santisteban y Bello sobre la definición del derecho de gentes, se puede encontrar que el primero es un sucesor de Vitoria y el segundo, de Hobbes y Bentham. Y esto se percibe mejor apreciando que Silva Santisteban reconoce la juridicidad del derecho internacional, es decir, lo concibe como Derecho y, por lo tanto, admite su fuerza jurídica. En contraste, Bello, si bien desarrolla las principales instituciones del derecho internacional, su concepción del derecho de gentes es la de una recopilación de normas, pero no de un sistema jurídico en sí. Como lo afirma el mismo Silva Santisteban, al señalar como "[...] fin del derecho internacional la seguridad y bienestar común, o en lenguaje de Bentham, la utilidad general; y por una consecuencia lógica se deduce de sus doctrinas la negación del derecho internacional, supuesto que no lo concibe como colección de leyes, cuya existencia implica la necesidad de una autoridad superior, de que carecen las naciones" (1856: p. 42).

Este desencuentro de posturas parte de que Silva Santisteban admite la sociabilidad de las naciones en el marco de la justicia, mientras que Bello, como lo demuestra su propia biografía, fue formado en Londres y bebió de los escritos de Bentham, alejándose de los ideales hispánicos descritos por Morse. En ese sentido, la reconciliación entre ambos autores es difícil de admitir, porque son hijos de su tiempo, pero de fuentes diferentes: Silva

29 Aquí cabe resaltar que, para el año de 1824, el presidente Monroe sostendrá que “América pertenece a los americanos", con el propósito de evitar la vuelta a la dominación de las potencias europeas hacia estas tierras. (Cassese 2013: p. 39). 
Santisteban es un iusnaturalista que pretende construir un derecho de gentes que parta de su originalidad hispánica, ese ideal de justicia vitoriano, mientras que Bello adopta el enfoque pragmático que le precede: una visión que, en el fondo, considera más la guerra que la paz como elemento trascendental configurador de las relaciones entre las naciones y, por lo tanto, se vuelve un conspicuo perseguidor de la utilidad general.

Se debe aquí advertir que Silva Santisteban, con mucha perspicacia, fue capaz de identificar a Bello como enemigo ideológico en su obra. Es más el autor peruano afirma que "es tan seductor el lenguaje de bien público, halaga y fascina tanto que no solo ha sido el talismán de las naciones, sino que los publicistas de nuestros días aceptan y propagan sus doctrinas [...] Bello lo designa con el nombre de seguridad y bienestar común. Las palabras son varias, la idea una misma: interés, bienestar, felicidad, seguridad, todo indica la utilidad y nada más; todos son discípulos de Bentham" (Silva Santisteban 1856: p. 50).

Silva Santisteban sostiene la posibilidad de la justicia y llama a Bello de negador del derecho internacional, al ser discípulo de Bentham, y, en el fondo, un defensor de la utilidad. En el fondo, los valores que se contraponen entre sí, de estos autores, son la justicia y la utilidad, la abstracción y la individualización. Tales ideales generan perspectivas y resultados diferentes en el esquema de la relación entre las naciones. La adopción de la justicia como valor demuestra que Silva Santisteban es un iusnaturalista, mientras que en Bello vemos un utilitarista. El primero sostendrá el carácter científico del Derecho y el segundo se limitará, pese a su nivel de instrucción, el cual es innegable, a cumplir "el papel de compilador al de reformador" (1856: p. 42).

\section{CONCLUSIONES}

El estudio histórico del derecho internacional realizado a través de la figura de Silva Santisteban y Bello demuestra que estos autores, siendo pensadores del ius gentium pertenecientes a las Américas, son una prueba de que la aproximación hacia el derecho de gentes en el siglo XIX no puede seguir haciéndose desde una tesis tradicionalista, por la cual se asuma que 
la matriz europea se haya trasladado sin más a nuestro continente, sino que es fundamental partir de una mirada crítica: Silva Santisteban y Bello son muestras, cada uno con su propio perfil, de no ser simplemente receptáculos del derecho internacional construido en Europa.

Silva Santisteban y Bello encarnan el debate que Morse retrata en $O$ espelho de Próspero: cultura e idéias nas Américas entre la opción ibérica y la opción inglesa, entre el neotomismo y el empirismo, respectivamente. En el fondo, es un debate que se produce entre los que afirman y niegan el derecho internacional y su carácter científico. Silva Santisteban sería un descendiente de Vitoria y Bello un descendiente de Hobbes y Bentham. En ese plano, Silva Santisteban parte, entre otros motivos, de criticar la obra Principios de derecho internacional de Bello por haber renunciado a la búsqueda de cientificidad del derecho de gentes. Además, Silva Santisteban parece ser mucho más consciente que Bello sobre el perfil histórico de su posición y lo critica ferozmente, calificándolo de empirista.

Como se ha explorado en este trabajo, Silva Santisteban constituye un formulador del derecho internacional en su carácter de ciencia, sin dejar por ello de considerarla basada en los "principios eternos de justicia". En contraste, Bello únicamente es capaz, y en ello coincide con Silva Santisteban, de sostener que el derecho internacional es una lista o recopilación de normas, sin preocuparse por dotar a esta rama de un carácter científico. En ese sentido, las definiciones del derecho internacional que manejan estos autores demuestran no solo que uno es un afirmador del derecho internacional y el otro un negador de su carácter científico, sino que, además, permite visualizar la lucidez de Morse de graficar el debate entre neotomismo y empirismo en la formación de la historia de las Américas, porque esta desciende en las personas de estos autores y se produce en un área tan específica como la del derecho de gentes.

\section{BIBLIOGRAFÍA}

Anghie, A. (1996). Francisco de Vitoria and the Colonial Origins of International Law. En: Social \& Legal Studies, vol. 5, n. ${ }^{\circ}$ 3, pp. 321-336. 
Armitage, D.; Pitts, J. (2017). The Law of Nations in Global History, Oxford: Oxford University Press.

Aristóteles (1989). Politeia (La Política), Bogotá: Instituto Caro y Cuervo (Ed. por Briceño Jauregui).

Basadre Ayulo, J. (2001). Los juristas de la República del Perú en el siglo XIX: Francisco García Calderón Landa. En: Revista de Estudios HistóricoJurídicos, vol. XXIII, pp. 471-486.

Becker Lorca, A. (2010). Universal International Law: Nineteenth-Century Histories of Imposition and Appropriation. En: Harvard International Law Journal, vol. 51, n. ${ }^{\circ}$, pp. 475- 552.

Bello, A (1981). Obras completas de Andrés Bello, vol. X (Derecho Internacional), Caracas: Fundación La Casa de Bello.

Bello, A. (1873). Principios de derecho internacional, 3ra. Ed., Chile: Pablo Dupont.

Brett, A. Chapter 46, Francisco de Vitoria (1483 - 1546) and Francisco Suárez (1548 - 1617). En: Fassbender, B. y Peters, A. (2012). The Oxford Handbook of the History of International Law, Oxford: Oxford University Press.

Cassese, A. (2013). Diritto internazionale (a cura di Paola Gaeta), Bolonia: Il Mulino.

Clapham, A. (2012). Brierly's Law of Nations, Oxford: Oxford University Press.

Daillier, P. ; Forteau, M.; Pellet, A. (2009). Droit international public, Paris: L.G.D.J.

De Vitoria, F. (1975) Relecciones de indios y el derecho de guerra, Madrid: Espasa Calpe, Tercera edición.

De Vitoria, F. (2008). Relectio de potestate civili. Estudios sobre su filosofía política. (Ed. Cordero Pando, J.), Madrid: Consejo Superior de Investigaciones Científicas. 
Flórez, G. (1999). De la sociedad feudal a la génesis del Estado moderno en Europa Occidental. En: Agenda Internacional, vol. 6, n. ${ }^{\circ}$ 12, pp. 113-122.

Franca, M. (2006). Historia y Razón del Paradigma Westfaliano. En: Revista de Estudios Políticos (nueva época), n. ${ }^{\circ} 131$, pp. 87-111.

Gómez Robledo, A. (1989). Fundadores del derecho internacional, México: Universidad Nacional Autónoma de México.

Hobbes, T. (1987). De Cive, Oxford: Oxford University Press (Ed. por Warrender).

Hobbes, T. (1998). Leviathan, Oxford: Oxford University Press (Ed. por Gaskin).

Iannarone, R. (1970). La maturazione delle idee coloniali in Francisco de Vitoria. En: Angelicum, Vol. 47, N. ${ }^{\circ}$ 1, pp. 3-43.

José Contreras, F. (2016). La filosofía del Derecho en la Historia. Madrid: Tecnos ( $2^{\circ} \mathrm{Ed}$.).

Miaja de la Muela, A. (1965). El Derecho "Totius Orbis" en el pensamiento de Francisco de Vitoria. En: Revista Española de Derecho Internacional, vol. 18, n. $^{\circ} 3$, pp. 341-364.

Morse, R. (1988). O espelho de Próspero, cultura e idéias nas Américas, trad. Neves, P., Sao Paulo: Companhia das Letras.

Murphy, Sean. (2012). Principles of International Law, Estados Unidos de América: Thomson Reuters.

Neff, S (2014). Justice Among Nations. A History of International Law, Estados Unidos de América: Harvard University Press.

Olano, H. (2007). Andrés Bello, el jurista de las Américas. En: Dikaion, año 21, n. ${ }^{\circ} 16$, pp. 67-73.

Orakhelashvili, A. (2011). The relevance of theory and history - the essence and origins of international law. En: Orakhelashvili, A. (Ed.) Research Handbook on the Theory and History of International Law, Cheltenham: Elgar. 
Osterhammel, Jürgen. (2015). La transformación del mundo. Una historia del siglo XIX, Barcelona: Planeta.

Otero Parga, M. (2017). ¿Influyó Suárez en el pensamiento de Andrés Bello? En: Anales de la Cátedra Francisco Suárez, n. ${ }^{\circ}$ 51, pp. 79-100.

Reale, G. ; Antiseri, D. (1988). Historia del pensamiento filosófico y cientifico. Del romanticismo hasta hoy, vol. 3, Barcelona: Herder.

Rosales Zamora, P. (2018). Sobre la vocación por el Derecho internacional público: consideraciones en torno a su estudio. En: Ius Inter Gentes, Revista de Derecho Internacional y Relaciones Internacionales, año $1, \mathrm{n}^{\circ}{ }^{1}$, $\mathrm{pp}$. 15-30.

Sánchez de Puerta Trujillo, F. (2006). Los tipos ideales en la práctica: significados, construcciones, aplicaciones. En: Revista de Metodología en Ciencias Sociales, N. ${ }^{\circ} 11$, pp. 11-32.

Silva Santisteban, J. (2018). Curso de derecho internacional o de gentes (1856), Lima: Centro de Estudios Constitucionales.

Truyol y Serra, A. (1998). Historia del Derecho Internacional Público. Madrid: Tecnos.

Walz, G. (1943). Derecho internacional y crítica de sus negadores. Madrid: Revista de Derecho Privado.

Weber, M (2016). La ética protestante y el «espíritu» del capitalismo, Madrid: Alianza editorial (Ed. Por Abellán, J.). 


\title{
ANÁlisis CRÍTICO DEL CONCEPTO DE APÁTRIDA DE FACTO
}

\author{
CRITICAL ANALYSIS OF THE CONCEPT OF DE FACTO STATELESSNESS
}

Juan Fuentes \& David Sánchez*

\section{RESUMEN}

El presente artículo tiene como finalidad analizar de forma concisa la definición de apatridia de iure contenida en el artículo 1, inciso 1 de la Convención sobre el Estatuto de los Apátridas (1954) y criticar el concepto de apatridia de facto que ha desarrollado un grupo de expertos convocado por el Alto Comisionado de las Naciones Unidas para los Refugiados (ACNUR).

Palabras clave: Derecho Internacional - Derechos Humanos Nacionalidad - Apatridia - Refugiados

Juan Andrés Fuentes Véliz

Abogado por la Pontificia Universidad Católica del Perú. Magíster en Derecho Internacional por la Universidad Católica de Lovaina (Bélgica). Magíster en Derecho de los Negocios por la McGeorge School of Law University of the Pacific (Estados Unidos de América). Doctor en Derecho por la Universidad de San Martin de Porres (Perú). Correo electrónico: fuentes.ja@pucp.edu.pe

David Sánchez Velásquez

Abogado por la Pontificia Universidad Católica del Perú. Estudiante del Máster Universitario en Políticas Públicas y Sociales en la Barcelona School of Management de la Universidad Pompeu Fabra, España. Correo electrónico: david.sanchez@pucp.pe. 


\section{ABSTRACT}

This article studies the definition of de iure statelessness contained in article 1, (1) of the Convention Relating to the Status of Stateless Persons (1954) and criticizes the UNHCR'S concept of de facto statelessness.

Keywords: International Law - Human Rights - Nationality Statelessness - Refugee.

\section{INTRODUCCIÓN}

Hacia el segundo semestre del 2017, una masiva vejación de derechos humanos tuvo lugar en el sudeste asiático. Las voces de protesta dentro de la comunidad internacional no repercutieron en la medida en que un hecho de estas proporciones merecía. En la fecha antes señalada, medio millón de rohingyas se vieron forzados a cruzar la frontera de Bangladesh, huyendo de la persecución que sufrían en Myanmar, Estado del cual son originarios, pero que les niega, desde hace un par de décadas atrás, el reconocimiento de la nacionalidad. El padecimiento que afrontaron y que, aún hoy, penosamente deben encarar los rohingyas puede sintetizarse en el siguiente comentario: "They are derided as 'illegal immigrants' [...] They need government permission to leave their villages, to marry, or to have more than two children" (Fullerton, 2014:147). El caso de los rohingyas es de suma importancia, pues este grupo étnico conforma alrededor del $10 \%$ de los cerca de diez millones de apátridas que existen en el mundo ${ }^{1}$.

A pesar de que los apátridas representan a un colectivo en especial situación de vulnerabilidad y, además, constatando que algunos Estados no defienden ni protegen los derechos fundamentales de este grupo con la debida diligencia, la doctrina peruana dedicada al Derecho Internacional Público no ha profundizado en el estudio del fenómeno de los apátridas y ni

1 Para mayor información véase Deutsche Welle (2017). 
en la problemática que los aquejan. En ese sentido, el presente artículo busca resarcir escuetamente esa falencia. Por consiguiente, analizará la definición de apatridia de iure contenida en la Convención sobre el Estatuto de los Apátridas (1954) y planteará una visión crítica del concepto de apatridia de facto elaborado por un grupo de expertos convocado por el Alto Comisionado de las Naciones Unidas para los Refugiados (ACNUR). Todo ello, en aras de concientizar a los lectores sobre este grave problema.

\section{LA DEFINICIÓN DE APÁTRIDA DE IURE DE ACUERDO A LA CONVENCIÓN SOBRE EL ESTATUTO DE LOS APÁTRIDAS DE 1954}

La Convención sobre el Estatuto de los Apátridas, suscrita el 28 de septiembre de 1954 en Nueva York, Estados Unidos de América-Convención que, por el momento, tan solo cuenta con 94 Estados parte ${ }^{2}$-, estipula en su artículo 1, inciso 1 la definición del término apátrida:

“A los efectos de la presente Convención, el término «apátrida» designará a toda persona que no sea considerada como nacional suyo por ningún Estado, conforme a su legislación".

Si bien pareciera que la definición citada es clara en sus términos -un apátrida es un individuo sin nacionalidad-, esta ha merecido un destacable trabajo exegético por parte del Alto Comisionado de las Naciones Unidas para los Refugiados (ACNUR), encargada también de velar por la protección de los apátridas ${ }^{3}$.

2 Vale la pena mencionar que son 193 los Estados parte de la Carta de las Naciones Unidas, marcando así una notoria diferencia comparativa con relación a los que son Estados parte de la Convención de sobre el Estatuto de los Apátridas (1954). El Estado peruano ratificó la Convención sobre el Estatuto de los Apátridas el 17 de diciembre de 2013 y entró en vigor para nuestro país el 23 de abril de 2014. Para mayor detalle, véase Archivo Nacional de Tratados Juan Miguel Bákula Patiño.

Recordemos que la Asamblea General de las Naciones Unidas, mediante las Resoluciones 3274 (XXIX) de 1974, 31/36 de 1976, 50/152 de 1996 y 61/137 de 2006, le encargó al ACNUR proteger y defender los derechos de los apátridas. 
Tanto las Directrices sobre la Apatridia No 1 (2012:2) como el Manual sobre la protección de las personas apátridas (2014:9), dos importantes documentos elaborados por el ACNUR, señalan que la definición de apátrida, siguiendo lo establecido por la Comisión de Derecho Internacional de las Naciones Unidas, forma parte del Derecho Internacional Consuetudinario. Ello resulta de relevancia, pues, todos los Estados, en principio, se encontrarían obligados a reconocer y respetar tal definición, en tanto, a partir de lo dispuesto en el tratado, que solo obligaba a los Estados parte, se ha ido generando una práctica internacional, con conciencia de vinculatoriedad, de reconocer a los apátridas bajo los parámetros de esa definición, dando pie al nacimiento de una norma consuetudinaria -de observancia obligatoria para los Estados parte y Estados no parte de la Convención de 1954- coincidente con la convencional.

Entrando propiamente al análisis de la definición de apátrida, ambos textos arriba citados indican que "[e]1 artículo 1(1) puede ser analizado mediante la división de la definición en dos elementos constitutivos: "no sea considerada como nacional suyo... conforme a su legislación' y 'por ningún Estado"” (ACNUR, 2012:4; ACNUR, 2014:11). En lo concerniente a esta última frase, cabe recordar que la Reunión de Expertos que discutió el concepto de apátridas de iure en el año 2010, determinó que,

"[c]uando se aplique la definición a menudo será prudente revisar primero la cuestión de 'Estado', como un análisis más de la relación del individuo con la entidad bajo consideración cuando es discutible si la entidad no califica como un 'Estado'. En situaciones donde un Estado no existe bajo el derecho internacional, las personas serán, ipso facto consideradas apátridas a menos que tengan otra nacionalidad" (ACNUR, 2010:2) (el énfasis es nuestro).

En síntesis, un individuo calificaría como apátrida cuando mantiene una relación con una entidad en la que no confluya, al menos, uno de los cuatro elementos constitutivos del Estado (territorio, población, gobierno y soberanía) que estipula la teoría predominante del Derecho Internacional Público al respecto 4 . Por ello, es importante evaluar, primero, la estatalidad

$4 \quad$ Para mayor información, véase Novak y García Corrochano (2001), así como el 
de la entidad con la que el individuo afirma tener vínculos, pues en caso no sea propiamente un Estado, el individuo devendría en apátrida.

Ahora bien, corresponde analizar la última parte de la oración mencionada, es decir, "no sea considerada como nacional suyo...conforme a su legislación". En este punto, se debe profundizar en el concepto y la relevancia de la nacionalidad en la protección y defensa de los derechos humanos. Al respecto, la Corte Internacional de Justicia esbozó una breve, pero clara definición de nacionalidad en los considerandos de la conocida y ampliamente estudiada sentencia del asunto Nottebohm (1955):

"la nacionalidad es un vínculo jurídico (...), [es] la expresión jurídica del hecho de que el individuo al cual se confiere [la nacionalidad] (...) está (...) más estrechamente vinculado a la población del Estado que se la ha conferido que a la de cualquier otro" (Casanovas y La Rosa, 1984:341-342).

Por su parte, Novak y García-Corrochano precisan que, cuando se define a la nacionalidad como un vínculo jurídico entre el Estado y el individuo, quiere expresarse "la existencia de ciertos derechos y deberes recíprocos [entre el Estado y el individuo, claro está]" (2001:315). De esta manera, el no ser considerado nacional por un Estado implica no ostentar su nacionalidad y, por lo tanto, estar impedido de ejercer los derechos civiles y políticos que esa comunidad política le reconoce a sus miembros (Corte IDH, 2006:248).

Finalmente, el ACNUR ha señalado que el término "legislación" no solo debe abarcar a las leyes propiamente dichas, es decir, aquellas normas jurídicas emanadas del Poder Legislativo, sino también los decretos, los reglamentos y la costumbre.

Aunque no forman parte del análisis exegético del ACNUR, consideramos pertinente tener en cuenta las siguientes reflexiones. Como bien indica Herías Fernández, "es conveniente atender al momento temporal en el que la persona deviene apátrida, si lo es en el momento del nacimiento o con posterioridad a lo largo de su vida (...) [;] llamaremos al primer tipo de apatridia 'apatridia originaria'; y al segundo, 'apatridia sobrevenida"" (2012:6-7). Sobre la apatridia originaria, Remiro Brotóns nos recuerda que

primer capítulo de la tesis de Sánchez Velásquez, David (2017). 
"[e]s un hecho que las causas por las que una persona deviene en apátrida provienen generalmente (...) de los efectos perversos que provoca el juego de los criterios [jurídicos] de atribución de nacionalidad al confluir en una persona dada" (1997:478). A fin de explicar lo antes citado, el mismo autor ejemplifica lo dicho:

"[S]i C nace en un país regido por el ius sanguinis, siendo sus padres nacionales de otro país cuya nacionalidad se adquiere estrictamente por aplicación del ius soli, entonces C [...] será apátrida" (Remiro Brotóns, 1997:478).

En contraposición, la apatridia de iure sobrevenida puede darse cuando una persona pierde la única nacionalidad que ostentaba y no opta por ninguna otra. Al respecto, el profesor Remiro Brotóns también nos brinda un ejemplo:

"[E]n caso de matrimonio entre A y B, supongamos que el Estado de A impone la pérdida de la nacionalidad al que lo contrae con un extranjero, mientras que el Estado de B no contempla la adquisición de nacionalidad por matrimonio con un nacional; en ese caso A devendrá apátrida" (1997:478).

Por otro lado, otras situaciones en las cuales una persona se convierte en apátrida de iure pueden deberse a que dicha persona renuncia a su nacionalidad o hay un caso de sucesión de Estados en el que el Estado sucesor decide no reconocer a la población del Estado predecesor como sus nacionales.

Con el propósito de evitar el surgimiento de casos de apatridia como lo anteriormente apuntados, la comunidad internacional adoptó la Convención para Reducir los casos de Apatridia (1964). Dentro del cuerpo normativo de la Convención se instruye a los Estados parte a incluir en su legislación interna el otorgamiento de la nacionalidad bajo los principios del ius soli (artículo 1) y el ius sanguinis (artículo 4), así como el de regular la pérdida, privación y renuncia de la nacionalidad solo si el interesado cuenta con otra nacionalidad (artículos 5, 6, 7, 8). 


\section{LA DEFINICIÓN DE APÁTRIDA DE FACTO DE ACUERDO A LAREUNIÓN DE EXPERTOS DELACNUR SOBRE EL CONCEPTO DE PERSONAS APÁTRIDAS BAJO EL DERECHO INTERNACIONAL}

Conforme hemos visto en el acápite anterior, el concepto de apátrida de iure es aquel que encuadra dentro de la definición del artículo 1, inciso 1 de la Convención sobre el Estatuto de los Apátridas (1954). Sin embargo, es necesario recordar que existe un concepto paralelo al apátrida de iure, el denominado apátrida de facto o de hecho. Este término realiza su aparición formal en la Resolución I del Acta Final de la Conferencia de las Naciones Unidas sobre la Supresión o la Reducción de la Apatridia en lo Porvenir (1961), que, a la letra, señala:

\section{"La Conferencia}

Recomienda que los apátridas de hecho sean tratados en la medida de lo posible como apátridas de derecho a fin de que puedan adquirir una nacionalidad efectiva" (el énfasis es nuestro).

Debe mencionarse que el término apátrida de facto no está conceptualizado en ningún instrumento jurídico internacional (ACNUR, 2012:3; ACNUR, 2014:5). En consecuencia, el ACNUR, en el marco del 50 aniversario de la Convención para Reducir los casos de Apatridia (1961), convocó en la ciudad de Prato, Italia a un grupo de expertos internacionales para elaborar, entre otras cosas, las directrices que permitan arribar a una definición consensuada del apátrida de facto (ACNUR, 2010:1). En base a lo señalado, el referido cónclave puntualizó la noción de apátridas de facto o de hecho como a continuación se transcribe:

"[S]on personas fuera del país de su nacionalidad que no pueden o, por razones válidas, no están dispuestas a acogerse a la protección de ese país. La protección, en este sentido, se refiere al derecho de protección diplomática ejercida por el Estado de la nacionalidad (...) así como protección diplomática y consular y asistencia general, incluso en relación con el regreso al Estado de la nacionalidad" (ACNUR, 2010:6).

Ahora bien, es menester formularse la siguiente pregunta: ¿cuáles son las circunstancias bajo las cuales una persona no puede acogerse a la 
protección diplomática de su Estado? La reunión de expertos del ACNUR que estableció la definición arriba citada determina que esa "imposibilidad puede ser causada ya sea porque el país de nacionalidad niega su protección o porque el país de nacionalidad no pueda brindar protección debido a que, por ejemplo, está en un estado de guerra y/o no tiene relaciones diplomáticas o consulares con el país de acogida" (ACNUR, 2010:6).

De otro lado, el ACNUR ha determinado que los conceptos de apátrida de iure y apátrida de facto son excluyentes (2010:6). Ello es así, en tanto el apátrida de iure es aquel que no cuenta con una nacionalidad, mientras que el apátrida de facto sí cuenta con una, mas esta no le permite acceder a la protección diplomática.

Finalmente, cabría mencionar que los apátridas de facto, al no estar incluidos en la Convención sobre el Estatuto de los Apátridas (1954), no cuentan con un régimen convencional especial de protección, solo están amparados por el Sistema Universal de los Derechos Humanos (ACNUR, 2010:7).

\section{ASPECTOS CRÍTICOS DE LA DEFINICIÓN DE APÁTRIDA DE FACTO}

En este acápite, es menester analizar los aspectos críticos sobre el concepto de apátrida de facto que el presente artículo desea plantear. En tal sentido, resulta interesante traer a colación la definición de refugiado:

"[aquella persona] [...] que debido a fundados temores de ser perseguida por motivos de raza, religión, nacionalidad, pertenencia a determinado grupo social u opiniones políticas, se encuentre fuera del país de su nacionalidad y no pueda o, a causa de dichos temores, no quiera acogerse a la protección de tal país; o que, careciendo de nacionalidad y hallándose, a consecuencia de tales acontecimientos, fuera del país donde antes tuviera su residencia habitual, no pueda o, a causa de dichos temores, no quiera regresar a él"s.

$5 \quad$ Artículo 1.a de la Convención de Ginebra sobre el Estatuto de los Refugiados (1951). 
Profundizando en la materia y siguiendo lo propuesto por Bazay, la definición de refugiado antes referida tiene cinco aspectos relevantes: (i) "que la persona tenga temores fundados de ser perseguida"; (ii) "debe existir una persecución"; (iii) "los motivos [de] la persecución deben basarse en la raza, religión, nacionalidad, pertenencia a determinado grupo social $\mathrm{u}$ opiniones políticas"; (iv) "la persona debe encontrarse fuera del país [de su nacionalidad o] donde antes tuviera residencia habitual"; y (v) "la persona no puede o no quiere acogerse a la protección del país de origen o residencia" (2014:53).

Tomando en cuenta lo señalado, el concepto de refugiado tiene dos puntos en común con la definición de apátrida de facto: i) la persona debe hallarse fuera del Estado de su nacionalidad o de su residencia habitual y ii) no puede o no quiere acogerse a la protección de dicho Estado.

En primer lugar, hemos de anotar que durante la elaboración de la Convención sobre el Estatuto de los Apátridas (1954), no solo se buscó incluir a los apátridas de iure, sino también a los de facto. Sin embargo, Weissbrodt nos recuerda que "the drafters of the two Statelessness Conventions incorrectly assumed that all de facto stateless persons were, and would conceivably be, refugees" (2006:252).

Dado, pues, que se consideró que el concepto de refugiado subsumía al de apátrida de facto, se obvió su inclusión y regulación en la Convención de 1954, entendiendo que ya se encontraba amparado por la Convención de Ginebra sobre el Estatuto de los Refugiados (1951). No obstante, no todos los apátridas de facto sufren de persecución, por lo que no califican como refugiados, imposibilitando la subrogación de un concepto por el otro. Queda claro, entonces, que la definición de refugiado no subsume al de apátrida de facto, como, equivocadamente, consideraron los negociadores de la Convención de 1954.

No obstante lo anterior, la definición de apátrida de facto elaborada por el grupo de expertos convocado por el ACNUR presenta un serio inconveniente: todos los refugiados con nacionalidad encuadran en la noción de apátridas de facto. Expliquémonos mejor. Como señaláramos párrafos atrás, la definición de refugiado engloba los dos elementos constitutivos del concepto de apátrida de facto: i) hallarse fuera del Estado de su nacionalidad 
o del Estado en el cual residían habitualmente y ii) no poder o no desear acogerse a la protección de su Estado, pues este se las niega o no puede brindárselas.

Desde esa perspectiva, el concepto de refugiado entraña al de apátrida de facto y es allí, justamente, donde reside el problema, pues se da pie a la confusión terminológica entres dos estatutos jurídicos. Si bien es cierto que los apátridas de iure pueden ser a su vez refugiados, en el supuesto que esos apátridas sufran de persecución; ello no implica, per se, que todos los refugiados sean apátridas de iure. De similar forma, si bien puede haber apátridas de facto que califiquen como refugiados; no todos los refugiados pueden calificar como apátridas de facto.

En efecto, la definición de una determinada categoría jurídica no debe ser ambigua en términos que permita su superposición con otra. La elaboración de definiciones jurídicas se hace justamente con el fin de brindar claridad respecto a las diversas instituciones del derecho y no confusión. Lamentablemente, esto último está ocurriendo con la definición de apátrida de facto, la cual, como repetimos, encaja dentro de la noción de refugiado, obviando las notas características que deben diferenciarlas.

\section{CONCLUSIÓN}

Habiéndose detectado un error en la definición del concepto de apátrida de facto, elaborado por el grupo de expertos de ACNUR, en la medida que se presta a confusión con el concepto de refugiados, y tras recoger la primera de las definiciones dos de sus elementos característicos -i) que el individuo esté fuera del Estado de su nacionalidad y ii) que el individuo no pueda o, por motivo fundado, no esté dispuesto a acogerse a la protección del Estado del cual es nacional-, entendemos que resulta necesario replantear tal definición. Lo anterior adquiere mayor importancia aún si se pondera el peso que la opinión de dicho grupo de expertos tiene no solo para la definición de la línea de acción de ACNUR, sino por la influencia que pueda tener para entes jurisdiccionales supranacionales, la doctrina y la comunidad internacional en general. 
En tal sentido, dado que uno de los propósitos del presente artículo es, precisamente, dar cuenta de los problemas de la definición de apátrida de facto, no resulta pertinente brindar una nueva definición. De ello se encargarán los expertos participantes de una futura conferencia internacional, que esperamos se convoque prontamente.

\section{BIBLIOGRAFÍA}

Documentos internacionales

Alto Comisionado de las Naciones Unidas para los Refugiados (ACNUR) (2012). Directrices sobre la Apatridia Nro. 1: La definición de "Apátrida” en el artículo 1(1) de la Convención sobre el Estatuto de los Apátridas de 1954, disponible en http://www.acnur.org/t3/fileadmin/scripts/doc.php?file=t3/ fileadmin/Documentos/BDL/2012/8471

Alto Comisionado de las Naciones Unidas para los Refugiados (ACNUR) (2010). Reunión de Expertos. El concepto de personas apátridas bajo el Derecho Internacional. Resumen de las conclusiones, disponible en http:// www.refworld.org/cgi-bin/texis/vtx/rwmain/opendocpdf.pdf? reldoc $=$ $y \&$ docid $=4$ cea $266 \mathrm{~d} 2$

Alto Comisionado de las Naciones Unidas para los Refugiados (ACNUR) (2014). Manual sobre la protección de las personas apátridas, disponible en https://www.refworld.org/cgi-bin/texis/vtx/rwmain/opendocpdf.pdf?rel $\mathrm{doc}=\mathrm{y} \&$ docid $=55 \mathrm{e} 94 \mathrm{c} 964$

Convención de Ginebra sobre el Estatuto de los Refugiados (1951)

Convención sobre el Estatuto de los Apátridas (1954)

Convención para Reducir los casos de Apatridia (1964)

Corte Interamericana de Derechos Humanos (Corte IDH) (2005). Caso de las niñas Yean y Bosico vs. República Dominicana. Sentencia de 8 de septiembre. 
International Law Commission. Draft Draft articles on Diplomatic Protection. Disponible en http://legal.un.org/ilc/texts/instruments/english/ draft_articles/9_8_2006.pdf

\section{Artículos}

Deutsche Welle (2017). "Los rohingya en Myanmar: las claves del conflicto", disponible en http://www.dw.com/es/los-rohingya-en-myanmarlas-claves-del-conflicto/a-40359299

Fullerton, Maryellen (2014). "The Intersection of Statelessness and Refugee Protection in US Asylum Policy", en Journal on Migration and Human Security, volume 2, number 3, 144-164.

Ruda Santolaria, Juan José (1998). "Algunas reflexiones en materia de nacionalidad", en Ius et Veritas, año IX, número 17, 222-225.

Weissbrodt, David (2006). "The Human Rights of Stateless Persons", en Human Rights Quarterly, 28, 245-276.

\section{Tesis}

Bazay, Lorena (2014). El lado humano del cambio climático. Nuevos retos para el derecho internacional. Tesis para optar por el título de Abogado. Facultad de Derecho de la Pontificia Universidad Católica del Perú.

Herías Fernández, Borja Manuel (2012). Los apátridas como grupo vulnerable: concepto y regulación. Trabajo de fin de máster. Maestría en Protección Jurídica de las Personas y Grupos Vulnerables. Universidad de Oviedo, España, disponible en http://digibuo.uniovi.es/dspace/ bitstream/10651/4027/1/TFM\%20Borja\%20Her\%C3\%ADas.pdf

Sánchez Velásquez, David (2017). "La nacionalidad en el contexto de la extinción de Estados por efectos del cambio climático". Tesis para optar el título de Abogado. Facultad de Derechos de la Pontificia Universidad Católica del Perú, disponible en http://tesis.pucp.edu.pe/repositorio/ handle/123456789/8546 


\section{Libros}

Casanovas y La Rosa, Oriol (1984). Casos y textos de Derecho Internacional Público. Madrid: Tecnos.

Novak Talavera, Fabián y Luis García-Corrochano Moyano (2001). Derecho Internacional Público. Tomo II. Sujetos de Derecho Internacional. Volumen I. Lima: Fondo Editorial de la Pontificia Universidad Católica del Perú.

Remiro Brotóns, Antonio et al. (1997). Derecho Internacional. Madrid: McGraw-Hill, 1997. 



\section{LA REGULACIÓN JURÍDICA DE LAS RELACIONES PATRIMONIALES DE LAS PAREJAS INTERNACIONALES EN LA UE}

THE LEGAL REGULATION OF THE INTERNATIONAL COUPLES PROPERTY RELATIONSHIPS IN THE EU

Ubaldo Greco*

\section{RESUMEN}

Cuando la pareja tiene una dimensión internacional por concurrir algún elemento extranjero, sea por la distinta nacionalidad o residencia de sus miembros integrantes, por la ubicación de los bienes que componen su patrimonio en diferentes Estados, etc., resulta sumamente conveniente establecer reglas armonizadoras para lograr soluciones uniformes ante los eventuales problemas que se puedan suscitar. De este modo, se potencia la seguridad jurídica y se favorece exponencialmente la libertad de circulación de las parejas internacionales. Para dar cumplimiento a dichos objetivos se promulgaron los Reglamentos (UE) 2016/1103 y 2016/1104 cuya plena aplicación ha tenido lugar a principios de 2019 y que, a pesar de haber sido gestados en el seno de la Unión Europea, en sus aspectos subjetivos están dirigidos a cónyuges y parejas de hecho provenientes también de terceros países.

Palabras clave: Unión Europea; Parejas internacionales; Reglamento (UE) 2016/1103, de 24 de junio de 2016; Reglamento (UE)

* Investigador del Departamento de Derecho Internacional Privado de la Universidad de Sevilla. Master's degree in Law, Sapienza University of Rome. Actualmente cursa el Master of Arts (MA) in International Public Affairs, LUISS School of Government (Rome). 
2016/1104, de 24 de junio de 2016; Regímenes económicos matrimoniales; Efectos patrimoniales de las uniones registradas; Reglas armonizadoras; Cooperación reforzada.

\section{ABSTRACT}

When the couple has an international dimension due to some foreign element, either because of the different nationality or residence of its members or because of the location in various States of the goods that compose its patrimony, etc., it is highly desirable to lay down harmonized rules for achieving uniform solutions to any problems that might arise. In doing so, legal safeguard is enhanced and the freedom of movement of the international couples is extremely favored. In order to achieve those objectives, the Council Regulations (EU) 2016/1103 and 2016/1104 were promulgated, whose full implementation has taken place early 2019 and, even though they were conceived within the European Union, are aimed at spouses and domestic partnerships from anywhere in the world in their subjective aspects.

Keywords: European Union; International couples; Council Regulation (EU) 2016/1103 of 24 June 2016; Council Regulation (EU) 2016/1104 of 24 June 2016; Matrimonial property regimes; Property consequences of registered partnerships; Harmonised rules; Enhanced cooperation.

\section{INTRODUCCIÓN}

El día 8 de julio de 2016 se publicaron en el Diario Oficial de la Unión Europea el Reglamento (UE) 2016/1103 del Consejo, de 24 de junio de 2016, por el que se establece una cooperación reforzada en el ámbito de la competencia, la ley aplicable, el reconocimiento y la ejecución de resoluciones en materia de regímenes económicos matrimoniales (en 
adelante Reg. REM) ${ }^{1}$ y el Reglamento (UE) 2016/1104 del Consejo, de 24 de junio de 2016, por el que se establece una cooperación reforzada en el ámbito de la competencia, la ley aplicable, el reconocimiento y la ejecución de resoluciones en materia de efectos patrimoniales de las uniones registradas (en adelante Reg. EPUR) ${ }^{2}$.

Los dos Reglamentos, también conocidos como Reglamentos gemelos, tienen casi la misma estructura y numeración. Las diferencias se deben principalmente al estatus diferente de las parejas. Ambos logran la uniformidad referida a los efectos patrimoniales aplicables a los matrimonios o parejas registradas en los que concurran elementos transfronterizos.

Sin embargo, el resultado alcanzado no es enteramente satisfactorio, ya que para la aprobación de los Reglamentos fue necesario el recurso al procedimiento de cooperación reforzada ${ }^{3}$. Esto representa una oportunidad perdida de realizar un importantísimo paso adelante hacia la definitiva comunitarización del derecho internacional privado, especialmente en el ámbito del derecho de familia.

En cuanto a las cooperaciones reforzadas, si hasta 2010 no se materializaron propuestas concretas, en los últimos años sí que se han iniciado algunas cooperaciones, especialmente en el Espacio de Libertad, Seguridad y Justicia. Ya podemos hablar de una Europa «a la carta» y «a dos velocidades», en la cual se manifiestan diversas actitudes de los Estados miembros en relación con la profundización en la integración, tendiendo algunos de ellos a pensar más sobre la base de su propio interés nacional y no comunitario.

\footnotetext{
DOUE L 183/1-29, 8-VII-2016.
}

DOUE L 183/30-56, 8-VII-2016.

La cooperación reforzada es un procedimiento que permite que un mínimo de nueve países de la UE consigan una mayor integración en algunos ámbitos de competencias no exclusivas de la Unión de forma transparente y democrática, sin la participación de los demás países de la UE. Sin embargo, los Estados no participantes en la cooperación tienen las puertas abiertas para adherirse a ella en todo momento, siempre que respeten la decisión inicial y las posteriores medidas. 


\section{2. ÁMBITO DE APLICACIÓN}

La normativa contenida en los Reglamentos requiere para su aplicación que quede totalmente perimetrado su ámbito de aplicación, el cual tiene cuatro vectores: espacial, personal, material y temporal.

Como cuestión previa es preciso aclarar que el legislador europeo, por un lado, no ofrece una definición de qué se entiende por matrimonio (de ahí que el Considerando 17 Reg. REM remita esta cuestión al Derecho nacional de los Estados miembros) y, por otro, establece una definición autónoma (esto es, restringida únicamente a los efectos del Reglamento 2016/1104) de "unión registrada" en el art. 3.1 a) Reg. EPUR, entendiendo por tal el "régimen de vida en común de dos personas regulado por ley, cuyo registro es obligatorio conforme a dicha ley y que cumple las formalidades jurídicas exigidas por dicha ley para su creación".

Fácil es suponer que este punto ha constituido, precisamente, la manzana de la discordia entre los Estados miembros en la fase de aprobación de los Reglamentos, dadas las distintas concepciones que existen en unas materias tan sensibles como son el matrimonio y las uniones de hecho, lo que provoca que algunos de aquellos no admiten la posibilidad de uniones matrimoniales y/o extramatrimoniales entre personas del mismo sexo. Preciso es, también, referirnos al carácter transfronterizo del litigio como presupuesto de aplicación de ambos Reglamentos, tal y como se recoge en los respectivos Considerandos 14 .

\section{1 Ámbitos espacial y personal}

Al haber sido gestados ambos instrumentos con el sistema de la cooperación reforzada, solo serán aplicables a los Estados que se hayan sometido al mismo, sin perjuicio de que este ámbito espacial se ensanche a medida que se vayan produciendo sucesivas adhesiones, según el Considerando 13 de ambos Reglamentos. Los Estados miembros que participan en la cooperación reforzada son: Alemania, Austria, Bélgica, Bulgaria, Chipre, Croacia, Eslovenia, España, Finlandia, Francia, Grecia, Italia, Luxemburgo, Malta, los Países Bajos, Portugal, la República Checa y Suecia. 
Dentro de los territorios de los Estados miembros que se encuentren vinculados por los Reglamentos, la aplicación de los mismos, desde el punto de vista personal, no presenta limitación alguna y se extiende a todas las personas, con independencia de cuál sea la nacionalidad que ostenten o de la residencia que tengan los cónyuges o los integrantes de las uniones registradas o las terceras personas que se relacionen económicamente con ellos.

De este modo, los Estados integrantes de la cooperación reforzada pueden aplicar la normativa de dichos Reglamentos tanto a nacionales de otros Estados miembros de la UE que no se hayan integrado en dicha cooperación, como a personas que sean nacionales o estén domiciliadas en terceros Estados.

\section{2 Ámbito material}

El paralelismo que existe entre ambos Reglamentos queda patente también en el ámbito material.

De entrada, el art. 3.1 a) Reg. REM define el régimen económico matrimonial como "el conjunto de normas relativas a las relaciones patrimoniales entre los cónyuges y con terceros, como resultado del matrimonio o de su disolución", mientras que el art. 3.1 b) Reg. EPUR entiende por efectos patrimoniales de las uniones registradas "el conjunto de normas relativas a las relaciones patrimoniales de los miembros de la unión registrada entre sí y con terceros, como resultado de la relación jurídica creada por el registro de la unión o su disolución".

Las nociones clave de "régimen matrimonial entre cónyuges y "efectos patrimoniales de las uniones registradas", se construyen, pues, a partir de nociones autónomas válidas a los solos efectos de aplicación de los respectivos Reglamentos, con independencia de que coincidan o no con las internas o sustantivas de los ordenamientos de los Estados partícipes en la cooperación, constituyendo el ámbito de aplicación positivo.

El ámbito material de los dos Reglamentos es bastante omnicomprensivo y abarca no solo los aspectos relativos a la gestión cotidiana de los bienes de los cónyuges o miembros de la pareja registrada, 
sino que también los relacionados con la liquidación como consecuencia de la separación o fallecimiento de los cónyuges o miembros de la unión registrada.

Además, hay que tener en cuenta que quedarían incluidos en el ámbito de aplicación del Reg. REM las normas del llamado régimen económico matrimonial primario y secundario. La circunscripción del ámbito material del Reglamento REM, en este sentido, no se recoge expresamente en ninguno de sus preceptos, pero se deduce del Considerando 18. Dada la distinta naturaleza jurídica de las uniones de hecho registradas, no se contiene en el Reg. EPUR ninguna previsión legal equiparable a la que se acaba de enunciar. No obstante, la posibilidad de que el conjunto de normas comprensivas de los efectos patrimoniales de las uniones registradas proceda tanto de la ley, como del acuerdo entre los miembros de la unión, aparece implícita en el art. 3.1. c) Reg. EPUR donde define las "capitulaciones de la unión registrada" en los mismos términos que el art. 3.1. b) Reg. REM establece para el matrimonio.

En sentido negativo las materias excluidas son, en primer lugar, las que tienen un carácter eminentemente público: las cuestiones fiscales, aduaneras y administrativas (respectivos arts. 1.1).

A continuación, ambos Reglamentos realizan exclusiones pormenorizadas de cuestiones que, a pesar de tener naturaleza privada, carecen del carácter disponible ínsito en lo relativo al régimen económico (respectivos arts. 1.2):

a) la capacidad jurídica de los cónyuges o miembros de la unión registrada; b) la existencia, validez y reconocimiento del matrimonio o de la unión registrada ${ }^{4}$; c) las obligaciones de alimentos ${ }^{5}$; d) la sucesión por causa de muerte de uno de los cónyuges o de los miembros de la unión registrada ${ }^{6}$; e) la seguridad social; f) el derecho de transmisión o ajuste entre los cónyuges o miembros de la unión registrada en caso de divorcio, separación judicial

\footnotetext{
$4 \quad$ Véanse Considerandos 64 Reg. REM y 63 Reg. EPUR.

Reguladas en el Reglamento (CE) 4/2009 del Consejo, de 18 de diciembre de 2008. Asimismo, disciplinada en el Reglamento (UE) 650/2012, del Parlamento Europeo y del Consejo, de 4 de julio de 2012.
} 
o anulación del matrimonio (disolución o anulación en el caso de unión registrada) de los derechos de pensión de jubilación o de invalidez devengados durante el matrimonio (o vigencia de la unión registrada) y que no hayan dado lugar a ingresos en forma de pensión durante el matrimonio o mientras haya durado la unión registrada ${ }^{7}$; g) la naturaleza de los derechos reales sobre un bien; h) cualquier inscripción de derechos sobre bienes muebles o inmuebles, incluidos los requisitos legales para llevarla a cabo, y los efectos de la inscripción o de la omisión de la inscripción de tales derechos en un registro.

\section{3 Ámbito temporal}

Siguiendo una pauta habitual en las medidas adoptadas en el campo de la cooperación judicial en materia civil, los Reglamentos distinguen dos momentos temporales netamente diferenciados: el de su entrada en vigor y el de su aplicación.

Este interregno de tiempo ha servido para que los Estados integrantes de la cooperación reforzada pudieran adecuar sus respectivas legislaciones internas. Con respecto al primero, dichos instrumentos reglamentarios están en vigor desde el día 29 de julio de 2016, es decir, a los veinte días de ser ambos publicados en el Diario Oficial de la Unión Europea.

No obstante, la aplicación completa de los Reglamentos se produjo el 29 de enero de 2019, ex respectivos arts. 70. 2. Tal disposición implica que las nuevas normas uniformes solo se aplicarán "a las acciones judiciales ejercitadas, a los documentos públicos formalizados o registrados y a las transacciones judiciales aprobadas o celebradas a partir del 29 de enero de 2019" (respectivos arts. 69. 1).

Finalmente, las normas del Reglamento que regulan la ley aplicable quedan circunscritas en su ámbito de aplicación temporal a los cónyuges o integrantes de la pareja que hayan contraído matrimonio o registrado su unión (o establecido la ley aplicable a su régimen patrimonial) con posterioridad al 29 de enero de 2019 (respectivos arts. 69. 3).

\footnotetext{
$7 \quad$ Véanse Considerandos 23.
} 
Está claro que, si en el futuro otros Estados miembros se integran en la cooperación reforzada, los Reglamentos les serán aplicables a partir de la fecha de la Decisión que autorice la incorporación (respectivos arts. 70. 2).

\section{SOLUCIONES PROPUESTAS}

La armonización establecida se dirige a lograr la seguridad jurídica en las relaciones transfronterizas dando respuesta a los tres grandes problemas que se pueden presentar en las relaciones jurídicas privadas internacionales: la determinación de la competencia judicial internacional; el señalamiento de la ley aplicable; el establecimiento de los mecanismos adecuados para el reconocimiento y ejecución de resoluciones judiciales y la aceptación y ejecución de documentos públicos y transacciones judiciales.

\subsection{Competencia judicial internacional}

Se parte de la premisa de que ambos Reglamentos potencian e incitan la posibilidad de que las partes resuelvan amistosa y extrajudicialmente el asunto relativo a sus relaciones económicas.

Las denominadas normas de competencia figuran en los respectivos Capítulos II y aclaran cuál es el órgano jurisdiccional competente para conocer de los asuntos que se susciten sobre la materia regulada en los Reglamentos REM y EPUR. Previamente, los Reglamentos gemelos dan una definición muy amplia de lo que se entiende por órganos jurisdiccionales (respectivos arts. 3.2), refiriéndose también a las autoridades y a los profesionales del Derecho que ejerzan funciones jurisdiccionales o que actúen por delegación de un órgano jurisdiccional, como puede ser el caso de los notarios.

Aclarado este punto, es necesario asumir sin ambages que los Reglamentos REM y EPUR usan dos técnicas distintas para determinar los respectivos tribunales de los Estados miembros competentes, aunque contemplan los mismos tipos de foros: en primer lugar, se prevé un criterio de conexidad y economía procesal allí donde sea posible; en según término, y únicamente cuando no haya conexidad o esta no sea aplicable, se hace 
referencia a un complejo sistema de foros, en el que algunos elementos se relacionan de forma alternativa y otros de manera subsidiaria.

La finalidad perseguida es que, en la medida de lo posible, los diferentes procedimientos que pudieran sustanciarse en Derecho de Familia sean conocidos por los órganos jurisdiccionales de un único Estado miembro, lo que requiere una concordancia por vía de remisión, tal y como establecen los arts. 4 y 5 de ambos instrumentos.

Naturalmente, la condición para que se opere la concentración de asuntos es que el órgano jurisdiccional que conozca de la sucesión (respectivos arts. 4) o de la crisis matrimonial o disolución o anulación de la unión registrada (respectivos arts. 5) pertenezcan a Estados que formen parte de la cooperación reforzada y, lógicamente, que ambos tipos de procesos no hayan concluido cuando surja la controversia en torno a los efectos patrimoniales del matrimonio o de las uniones de hecho registradas. En caso contrario, la competencia se determinará sobre la base de los foros establecidos en los siguientes artículos (respectivos arts. 6-11).

Los artículos 4 Reg. REMy Reg. EPUR, que coordinan los Reglamentos de que se trata con el Reglamento (UE) 650/2012 sobre las sucesiones mortis causa internacionales, establecen que los órganos jurisdiccionales que tengan competencia para la sucesión mortis causa conocerán también de los asuntos relativos al régimen económico matrimonial y a los efectos patrimoniales de las uniones registradas, por estar relacionados con esa sucesión. Se intenta de esta manera perseguir la coherencia del sistema de Derecho Procesal Civil Internacional de la Unión Europa.

Este automatismo se conserva, con algunas excepciones, en el art. 5 Reg. REM. Y precisamente, se dispone que el tribunal competente para conocer de un proceso relativo al régimen económico matrimonial ha de ser aquel que esté conociendo sobre la disolución del vínculo conyugal (divorcio, separación judicial o anulación del matrimonio) en virtud del Reglamento Bruselas II bis ${ }^{8}$. Sin embargo, y a diferencia de lo que ocurre en el caso de conexión con un proceso sucesorio, esta regla general puede ceder en favor de otros foros previstos en el Reg. REM, puesto que, como prevé

$8 \quad$ Reglamento (CE) n 2201/2003 del Consejo, de 27 de noviembre de 2003. 
el artículo 5.2 del Reg. REM, hay cuatro casos en los que la vis attractiva del proceso matrimonial respecto del proceso relativo al régimen económico matrimonial requiere del acuerdo entre los cónyuges; si este acuerdo no concurre, el tribunal que conoce del proceso matrimonial no atraerá hacia sí la competencia para el litigio relativo al régimen económico, que se determinará entonces a través de los foros contenidos en los artículos 6 a 11 del Reg. REM (Peiteado Mariscal, 2017, p. 318). Por lo que respecta a dicho acuerdo, el artículo 5.3 Reg. REM establece de forma expresa que si este se celebra antes de que se requiera al órgano jurisdiccional que resuelva sobre el régimen económico matrimonial, dicho acuerdo deberá reunir los requisitos del artículo 7.2 Reg. REM.

En cambio, téngase en cuenta que la competencia para conocer de un proceso relativo a los efectos patrimoniales de la unión registrada no es automáticamente atraída por el Estado cuyos tribunales conocen del proceso dirigido a disolver o anular la unión: se necesita siempre que los integrantes de la unión así lo acuerden, ex art. 5 Reg. EPUR. El motivo por el que la conexión se encuentra condicionada a dicho acuerdo se ha explicado partiendo de la ausencia de un Reglamento relativo a la competencia para disolver o anular uniones de hecho, lo que provoca la incapacidad del legislador europeo de asegurar la adecuación del foro relativo al conocimiento de procesos sobre efectos patrimoniales con los determinados en las diversas legislaciones internas para el conocimiento de la disolución o anulación de la unión (Peiteado Mariscal, 2017, pp. 323-324).

Cuando ningún órgano jurisdiccional de un Estado miembro tenga competencia con arreglo a los artículos 4 o 5 (Reg. REM y Reg. EPUR) o en otros casos distintos de los previstos en dichos artículos, el tribunal competente se determinará con arreglo a lo prescrito en los respectivos artículos 6 . Ambos recogen una lista de foros jerárquicamente enumerados, comenzando por la residencia habitual de los miembros de la pareja en el momento de la interposición de la demanda. En defecto, se hace referencia a la última residencia habitual si uno de ellos aún resida allí o, en tercer lugar, la residencia habitual del demandado. El cuarto criterio es la nacionalidad común de los cónyuges o de los miembros de la unión registrada en el momento de la interposición de la demanda. Por último, y tan solo en el 
Reglamento EPUR, se identifica un quinto foro según el cual, en defecto de los anteriores, serán competentes los órganos jurisdiccionales del Estado miembro conforme a cuya ley se haya creado la unión registrada.

Con el fin de acrecentar la previsibilidad y la libertad de elección de las partes, los respectivos artículos 7 contemplan la posibilidad de acordar la elección del foro para los casos contemplados en los artículos 6 (y por lo tanto la cláusula de elección es válida solo si no son aplicables los artículos 4 y 5 , por lo que se ha de verificar su existencia en defecto de los mismos y antes de la aplicación de los arts. 6). Específicamente, el art. 7 Reg. REM permite la sumisión expresa únicamente a los tribunales de dos Estados: los órganos jurisdiccionales del Estado miembro cuya ley sea aplicable al régimen económico matrimonial ${ }^{9}$ o bien los órganos jurisdiccionales del Estado miembro en el que se haya celebrado el matrimonio, aspirando de este modo a lograr la deseable equiparación fórum - ius. Análogamente, el art. 7 Reg. EPUR permite la atribución de la competencia expresa a las autoridades del Estado miembro cuya ley es aplicable con arreglo a los artículos 22 y 26.1, es decir la ley del Estado de residencia habitual o la ley del Estado de la nacionalidad de cualquiera de los miembros o futuros miembros de la unión registrada (teniendo en ambos casos en cuenta el momento en que se celebre el acuerdo), así como la ley del Estado conforme a cuya ley se haya creado la unión registrada.

Los siguientes artículos 8 permiten que la competencia internacional de los tribunales de los Estados miembros se fije mediante sumisión tácita del demandado, es decir mediante su comparecencia, siempre que esta no tenga como objetivo la impugnación de la competencia, ni en los casos regulados por los arts. 4 o 5.1 Reg. REM y 4 Reg. EPUR.

Ahora bien, es necesario que el tribunal al que la sumisión tácita del demandado le otorgaría competencia verifique que el demandado sea informado de su derecho a impugnar la competencia y, al mismo tiempo, sea

$9 \quad$ Es decir, la ley del Estado de residencia habitual o de la nacionalidad de cualquiera de los cónyuges o futuros cónyuges con respecto al momento de la celebración del acuerdo y la ley del Estado de la primera residencia habitual común de los cónyuges tras la celebración del matrimonio o, en su defecto, de la nacionalidad común de los cónyuges en el momento de la celebración del matrimonio, ex artículos 22, 26.1 a) o 26.1 b) Reg. REM. 
consciente de las consecuencias de su comparecencia o incomparecencia. Sin embargo, para que sea válida la aplicación de los arts. 7 y 8 es necesario que el derecho aplicable o, en el caso de sumisión expresa, el lugar de la celebración del matrimonio o el lugar conforme a cuya ley se haya creado la unión registrada, se localicen en Estados miembros vinculados por los Reglamentos (Quinzá Redondo, 2017, p. 198).

Los Reglamentos permiten, por otro lado, inhibirse al órgano jurisdiccional inicialmente competente, sin dilación indebida, si se considera que en su Derecho nacional no está reconocido el matrimonio que requiere de una solución para la cuestión del régimen económico matrimonial o la institución de la unión registrada. Para obviar situaciones de denegación de justicia, el legislador europeo ha establecido algunos foros de competencia alternativa, recogidos en los artículos 9 Reg. REM y Reg. EPUR. Si las partes están de acuerdo, la competencia alternativa se puede atribuir a las autoridades de otro Estado miembro, estableciéndose distintas soluciones en atención al foro del Reglamento que haya fundamentado la competencia judicial internacional del órgano que conoce del asunto. Sin embargo debe prestarse atención a una importante excepción: el Estado miembro del órgano jurisdiccional requerido seguirá siendo competente siempre que reconozca una resolución (dictada anteriormente) en materia de divorcio, separación o disolución del matrimonio o de la unión registrada. En ese caso, nada se opone a que pueda también conocer acerca de uno de los efectos más relevantes de la disolución, cual es la cuestión del régimen económico matrimonial o de los efectos patrimoniales.

Incluso podría pasar que ningún Estado miembro sea competente en aplicación de los artículos anteriores. Se trata de un caso muy improbable con respecto al cual, de todos modos, los Reglamentos gemelos han dado respuesta introduciendo una hipótesis de competencia subsidiaria mediante los respectivos artículos 10. Según lo previsto en ambos Reglamentos, se garantiza el acceso a la justicia de las partes interesadas ante los órganos jurisdiccionales del Estado miembro en el que uno o ambos miembros de la pareja posean el bien o los bienes inmuebles ${ }^{10}$. Debe tratarse, como es obvio,

$10 \quad$ Esta disposición está inspirada en el artículo 10.2 del Reglamento (UE) nº 650/2012. 
de bienes inmuebles situados en Estados que participan de la cooperación reforzada.

En estos casos, los órganos jurisdiccionales solo tendrán competencia para resolver sobre el bien o los bienes inmuebles de que se trata, limitando de hecho el litigio a uno o algunos bienes sin considerar todos aquellos comprendidos en el patrimonio de la pareja.

Dicha disposición es controvertida, considerando que uno de los objetivos declarados de los Reglamentos en examen es concentrar asuntos bajo un mismo tribunal, por lo que su admisión puede provocar una no deseada fragmentación en la solución, es decir, que existan tantas autoridades competentes como bienes tuvieran las parejas en los diferentes Estados (Rodriguez Benot, 2012, p. 565). Pero tampoco estamos ante un caso aislado, puesto que los Reglamentos prevén otra hipótesis en la que es posible que el litigio se limite a solo algunos bienes. Efectivamente, en los supuestos de fallecimiento de uno de los miembros de la pareja, los respectivos artículos 13 permiten la exclusión, a instancia de una de las partes, de aquellos bienes (de la herencia del causante) situados en un tercer Estado si hubiera riesgo de no reconocimiento de la decisión que afecta a dichos bienes.

Los respectivos artículos 11 introducen un foro de necesidad que será de aplicación en circunstancias excepcionales, cuando no sea posible acudir a ninguno de los órganos jurisdiccionales basándose en los artículos anteriores.

Por último, los artículos 12 a 19 de ambos Reglamentos contienen normas de competencia de orden técnico-procesal cuyo objetivo es evitar que se dicten resoluciones inconciliables en Estados miembros distintos ocupándose de la verificación de oficio y de las cuestiones de litispendencia y conexidad internacionales.

\subsection{Ley aplicable}

El Capítulo III de ambos Reglamentos está dedicado a la resolución de la cuestión de la legislación que se debe aplicar en cada caso específico. A pesar de la coincidencia numérica de los artículos de este capítulo en los Reglamentos REM y EPUR, no siempre se establecen reglas totalmente 
equiparables, debido a la diferente naturaleza jurídica de la relación matrimonial y extramatrimonial de la que se ocupa cada uno.

Sin embargo, las normas de conflicto se vertebran en torno a dos principios básicos: el de la universalidad y el de la unidad de la ley aplicable.

Según el primero, puede resultar potencialmente aplicable la ley de cualquier Estado, aunque no se encuentre vinculado por los Reglamentos gemelos (respectivos arts. 20). Ello implica la desaparición de la frontera entre Estados parte de la cooperación reforzada y aquellos otros que no se han vinculado, pues la ley que resulte finalmente aplicable puede, indistintamente, ser tanto la de unos como la de otros $y$, por supuesto, la de un Estado no miembro de la Unión europea.

La unidad viene consagrada de forma clara en los respectivos arts. 21, que extienden la aplicación de la ley resultante a todos los bienes englobados en el régimen económico matrimonial o en los efectos patrimoniales de las uniones registradas, al margen del lugar donde se encuentren. Se justifica tal opción por razones de seguridad jurídica para evitar la fragmentación, “con independencia de la naturaleza de los bienes y de si los bienes están situados en otro Estado miembro o en un tercer Estado" 11.

El loable deseo de favorecer la unidad del patrimonio con respecto a la unidad del pasivo puede verse empañado por la eventual descoordinación que se puede producir entre la ley aplicable, según los Reglamentos que se analizan, con la lex rei sitae, punto de conexión general para determinar la ley reguladora de las cuestiones atinentes a la propiedad y demás derechos reales, en especial, la exigencia de una determinada forma y publicidad (Quinzá 21Redondo, 2017, p. 194).

Previamente veremos las cuestiones a las que se extiende la regulación de la ley aplicable:

1) Ámbito de la ley aplicable.

Los respectivos arts. 27 se ocupan de enumerar las materias acogidas en la regulación de la ley aplicable, en términos semejantes y con carácter

11 Considerando 42 Reg. REM y 43 Reg. EPUR. 
meramente ejemplificativo (como lo demuestra la expresión "entre otras cosas" utilizada en ambos artículos). Para ello hacen una neta distinción entre las relaciones ad intra y ad extra.

En las primeras quedarían incluidos los aspectos patrimoniales de las relaciones económicas entre los cónyuges o miembros de la unión registrada, tanto durante la vigencia de las respectivas relaciones como en el momento de su extinción. Mientras que en los apartados f) se trata de dichas relaciones en su vertiente externa, esto es, con los terceros. A estas cuestiones se añade en los respectivos apartados g) la validez material de las capitulaciones matrimoniales y de las capitulaciones de la unión registrada, para la que se remite a lo establecido en el ordenamiento estatal que resulte aplicable.

El campo de relaciones externas ha motivado el diseño, por parte del legislador europeo, de una norma tuitiva para proteger los derechos de los terceros de buena fe que se relacionen con uno o ambos cónyuges o miembros de la unión registrada. Para ello se veda la posibilidad de invocar en un litigio la ley aplicable, por parte de estos, frente a un tercero a no ser que se demuestre, con base en una serie de presunciones que se establecen a continuación, que dicho tercero "conociera o actuando con la debida diligencia, debiera haber tenido conocimiento de dicha ley".

En el caso de que, finalmente, no pudiera ser invocada la ley que regula los efectos patrimoniales, ambos Reglamentos fijan las oportunas conexiones para regular las relaciones externas (respectivos arts. 28).

2) Determinación de la ley aplicable.

Hechas estas precisiones, la arquitectura de los Reglamentos en torno al problema de la ley aplicable se monta sobre dos pilares: la determinación de la ley aplicable hecha por las partes en uso de la autonomía de la voluntad y el establecimiento de un sistema de normas de conflicto subsidiarias para la hipótesis en la que los respectivos protagonistas de estas uniones matrimoniales o extramatrimoniales no hayan hecho uso de la professio iuris.

En lógica sintonía con lo que sucede en las legislaciones internas de los Estados miembros de la UE, la determinación por los cónyuges o miembros de la unión registrada de las reglas para regular sus relaciones 
económicas tiene prioridad sobre las impuestas por el legislador, pues son aquellos los que mejor conocen y pueden defender sus intereses de tal índole, de ahí la importancia de que la elección sea informada. Además, con ello se evita que los tribunales tengan que decidir sobre esta materia, por eso que el legislador europeo, en sus últimas reglamentaciones, ha extendido tal posibilidad a ámbitos que tradicionalmente quedaban fuera del radio de acción de dicho principio $^{12}$.

La consagración del principio en cuestión se encuentra en los respectivos arts. 22, que presentan ciertos matices diferenciales inevitables por la diferente situación de partida que acoge cada instrumento. Esta es la razón por la que en el primer párrafo del art. 22 Reg. EPUR se establece la prevención, de entrada, de que la ley elegida por ambos miembros reconozca efectos patrimoniales a la institución de la unión registrada ${ }^{13}$.

A continuación, en dichos artículos se determinan, alternativamente, las posibles leyes que se pueden elegir, ya que se trata de una autonomía de la voluntad conflictual limitada: la ley del Estado de la residencia habitual o de la nacionalidad de los cónyuges, miembros o futuros cónyuges o miembros de la unión registrada en el momento de celebración del acuerdo.

A estos tradicionales puntos de conexión se añade, para las uniones registradas, la ley del Estado conforme a cuya ley se haya creado la unión registrada.

La libertad de elección pivota, pues, en torno a la ley del lugar de residencia habitual, cuando así lo hagan constar por hallarse plenamente integrados en su nuevo entorno (posibilidad que no se debe descartar, ya que dados los flujos migratorios hay personas que salen de su país y no regresan jamás), o si lo prefieren la de su nacionalidad, con lo que se aseguran, en cierta medida, que la sentencia que recaiga va a ser reconocida y ejecutada

$12 \quad$ Véase, en tal sentido, el art. 22 Reglamento de Sucesiones 650/2012, el art.5 Reglamento sobre ley aplicable a la separación y al divorcio 1259/2010 y el art. 8 Reglamento de Alimentos 4/2009.

13 Lo que se justifica "para evitar que la elección de ley carezca de efecto alguno, dejando a los miembros de la unión registrada en un vacío legal" (ex Considerando 44 Reg. EPUR). 
en su país de origen ${ }^{14}$. Acotada de este modo la elección, lo que no existe es limitación alguna en cuanto al momento temporal en el que se puede llevar a cabo, así como en el número de cambios que eventualmente se pueden realizar (siempre que la elección recaiga sobre los mismos ordenamientos jurídicos: nacionalidad o residencia habitual de cualquiera de los miembros o, únicamente para las uniones registradas, ley del Estado conforme a la que se hayan creado). Dichos cambios tendrán eficacia ex nunc, salvo pacto en contrario, en cuyo caso siempre quedarán salvaguardados los derechos de terceros.

Los límites vuelven a aparecer con la imposición de ciertos requisitos formales en los respectivos arts. 23 (para los acuerdos de elección de ley aplicable) y 25 (para las capitulaciones matrimoniales o de la unión registrada). En efecto, siguiendo la estela dejada por los Reglamentos precedentes se exige, con carácter general, que el acuerdo se materialice por escrito fechado y firmado por ambos integrantes, aunque se extiende tal soporte a los medios electrónicos que puedan proporcionar "un registro duradero del acuerdo".

Los requisitos formales adicionales que se puedan establecer dependen de dónde tengan su residencia habitual los cónyuges o miembros de la unión registrada en el momento de la celebración del acuerdo. Si ambos la tienen en el mismo Estado miembro (se refiere solo a los Estados participantes en la cooperación reforzada) que los impone, dichos requisitos se deben observar, lo mismo que si es uno solo de los esposos o miembros de la unión registrada el que posee la residencia en dicho Estado miembro. Si la tienen en diferentes Estados miembros cuyas leyes exigen diversos requisitos, basta con que cumplan los requisitos de una de las dos leyes.

Las mismas soluciones se arbitran para el cumplimiento de la validez formal de las capitulaciones matrimoniales, con la evidente diferencia de

$14 \quad$ Lógicamente, cuanto más internacional sea la pareja más se abre el abanico de elección de leyes, teniendo en cuenta que la consideración de los sujetos con doble nacionalidad es una cuestión que se remite al Derecho nacional, aunque dicha consideración "no debe tener ninguna incidencia en la validez de la elección de la ley aplicable" de conformidad con los respectivos Reglamentos (ex Considerando 50 Reg. REM y 49 Reg. EPUR). 
que el lugar de residencia se toma en consideración en el momento de la celebración de las capitulaciones matrimoniales o de la unión registrada y con la sola adición de la necesidad del cumplimiento de los eventuales requisitos adicionales establecidos por la ley aplicable al régimen económico matrimonial o a los efectos patrimoniales, esto es por la ley sustantiva que los regule. No se exige, sin embargo el cumplimiento de los requisitos formales adicionales que pueden venir impuestos por las leyes de terceros Estados.

Finalmente, en los arts. 24 de ambos Reglamentos se articula el régimen al que se somete la validez material y el consentimiento de estos acuerdos remitiendo a la ley elegida, ex respectivos arts. 22, siempre que dicha elección fuese válida.

Con carácter excepcional se admite que uno de los miembros del matrimonio o de la unión registrada pueda invocar la ley del país de su residencia habitual en el momento de sustanciar el asunto ante el órgano jurisdiccional para probar la ausencia de su consentimiento, cuando no resultase razonable que el efecto de tal conducta quedara sometido a la ley elegida por ambos (respectivos arts. 24.2).

La norma de conflicto establecida con carácter subsidiario para la hipótesis de que las partes no hagan uso de la professio iuris o bien esta no sea válida es la que presenta mayor disparidad en su regulación por los dos Reglamentos, aunque numéricamente se utilice en ambos el art. 26. A estos efectos, el Reg. EPUR designa, como una única ley, la del Estado conforme a la que se haya creado la unión registrada. En cambio, el Reg. REM establece tres normas en cascada, aplicables jerárquicamente una en defecto de la otra. Y estas son la ley del Estado de la primera residencia habitual común de los cónyuges tras la celebración del matrimonio o, en su defecto, la de la nacionalidad común en el momento de la celebración del matrimonio (con la previsión de que si tuvieran más de una nacionalidad en común no opera este punto de conexión, para evitar "favorecer" una nacionalidad sobre otra) o, por último, la del país que presente la vinculación más estrecha con ambos cónyuges en este mismo momento, que actúa como conexión de cierre.

La regla general que se contiene en ambos Reglamentos, aunque con distintos puntos de conexión, ofrece en los dos la misma excepción, que es la posibilidad de aplicar la ley de un Estado distinto al de la primera 
residencia habitual común después de la celebración del matrimonio o del Estado en el que se haya creado la unión registrada, cuando así lo acuerde el juez a petición de cualquiera de los integrantes del matrimonio o de la unión registrada, siempre que en este último caso la ley de dicho Estado les atribuya efectos patrimoniales. Se conjura de este modo el peligro que puede suponer el que los integrantes de estas uniones, matrimoniales y extramatrimoniales, ya no se sientan identificados con la ley del país establecida como regla general (que toma como referente temporal el momento de la celebración del matrimonio o de la constitución de la unión registrada). De ahí que se otorgue la posibilidad de activar esta cláusula de escape dando lugar a la aplicación de la ley del Estado de la última residencia habitual común de los cónyuges o miembros de la unión registrada.

Ahora bien, para que entre en juego dicha excepción es preciso que la parte que lo solicita demuestre, cumulativamente, dos circunstancias de tipo fáctico, es decir, la mayor duración de la última residencia habitual común de la pareja en dicho Estado distinto y la planificación u organización de sus relaciones patrimoniales con base en la ley de ese otro Estado, requisito no exento de dificultad en cuanto a su prueba. En cualquier caso, se impone la necesidad de que los derechos de los terceros derivados de la ley de la residencia habitual común de los cónyuges o de la ley del Estado conforme a la que se haya creado la unión registrada no queden afectados negativamente y que no se hayan otorgado capitulaciones matrimoniales con anterioridad al establecimiento de su última residencia habitual común en el Estado distinto (respectivos arts. 26).

La gran complejidad que late en la excepción contemplada en los arts. 26 de ambos Reglamentos ha motivado una crítica desfavorable por parte de algunos autores, llegando a decir que "resulta claramente prescindible si lo que realmente se persigue es la previsibilidad y la seguridad jurídica" (Rodríguez Benot, 2019, p. 42).

3) Cuestiones comunes a todo tipo de leyes aplicables contenidas en los Reglamentos.

La autonomía de la voluntad de las partes, a pesar de cumplir con la función de fortalecer la seguridad jurídica en sus relaciones privadas transfronterizas vigorizando la mayor movilidad de los ciudadanos europeos, 
encuentra su límite en las llamadas leyes de policía y la excepción de orden público del foro.

En primer lugar, hemos de considerar la tradicional cláusula del orden público tal y como se regula en los respectivos arts. 31 . Según dicha cláusula, si de la aplicación de las reglas de conflicto contenidas en el Reglamento resultara aplicable una ley extranjera que vulnera el orden público del foro, dicha ley será inaplicable. Como complemento a dicha prohibición estaría la imposibilidad de vulnerar las leyes de policía (respectivos arts. 30). Esta denominación comprende las disposiciones que cada Estado considera primordiales para velar por sus intereses públicos y que, por tanto, se imponen para su aplicación con independencia de cuál sea la ley que resulte aplicable, si bien dicha excepción ha de ser objeto de interpretación restrictiva para no truncar el objetivo general perseguido por ambos Reglamentos cual es el de la unidad de ley aplicable. Los Considerandos 53 Reg. REM y 52 Reg. EPUR señalan, como ejemplo de leyes de policía, las normas de carácter imperativo establecidas para la protección de la vivienda familiar.

La exclusión del reenvío viene claramente establecida en los respectivos arts. 32, que determinan que la remisión a la ley de un Estado se entiende hecha a su ley material, con exclusión de su sistema de normas de Derecho Internacional Privado. Con dicha previsión se corta de raíz la posibilidad de utilizar las normas de conflicto de dicho Estado y, por tanto, que surja, al menos, una segunda remisión a la ley de otro Estado, requisito indispensable para que exista el reenvío, como mecanismo propio de la fisonomía de las normas de conflicto.

En fin, los Reglamentos se hacen eco de la problemática que entrañan las hipótesis de Estados plurilegislativos donde la respuesta inicialmente dada por la norma de conflicto deviene incompleta, pues al tratarse de países en los que coexisten diferentes sistemas legislativos, se impone la necesidad de concretar el particular derecho aplicable.

Para resolver esta cuestión se distingue, en los respectivos arts. 33 y 34, entre los conflictos territoriales (que se dan en aquellos Estados que comprenden varias unidades territoriales con sus propias normas jurídicas en materia de régimen económico matrimonial o de efectos patrimoniales de las uniones registradas) y los interpersonales de leyes (presentes en 
los Estados con dos o más regímenes jurídicos o conjuntos de normas aplicables a diferentes categorías de personas en las materias acabadas de mencionar).

Respecto a los Estados plurilegislativos de base personal, se prevé que toda referencia a la ley de tales ordenamientos debe entenderse como una remisión al sistema jurídico de las normas en vigor en tal Estado, es decir, que habrá que estar en primer lugar a lo que establezcan sus propias normas de conflicto y, en su defecto, aplicar el régimen jurídico o conjunto de normas con el que los miembros de la pareja en cuestión tengan una conexión más estrecha. Para el primer tipo de Estados remite a sus propias normas internas en materia de conflicto de leyes la determinación de la específica unidad territorial pertinente. Y, en defecto de tales normas, se prevén diversas soluciones según cuál haya sido el punto de conexión empleado por la norma de conflicto. Si se ha utilizado el criterio de la residencia habitual, se aplicará la ley de la unidad territorial en la que los elementos personales tengan su residencia habitual. En el caso en que se haya empleado el punto de conexión de la nacionalidad de las partes, deberá tomarse en consideración la ley de la unidad territorial con la que los cónyuges o miembros de la unión registrada tengan la conexión más estrecha. En el resto de las situaciones tendrá aplicación la ley de la unidad territorial donde el elemento en cuestión se encuentre situado. En conexión con la hipótesis anterior, la regulación de los conflictos interterritoriales se cierra con la disposición contenida en los arts. 35 de ambos instrumentos que, interpretada a sensu contrario, permitiría la aplicación de los Reglamentos para los conflictos puramente interregionales (es decir, aquellos que se presentan exclusivamente entre unidades territoriales de un mismo Estado).

\subsection{Reconocimiento y ejecución}

Gran parte de las medidas estudiadas hasta aquí van dirigidas a la obtención de una resolución que, por el escenario internacional en el que nos movemos, ha de surtir efecto en un Estado distinto de aquel cuyos órganos jurisdiccionales la dictaron. Asimismo, en muchas ocasiones, los documentos públicos y transacciones judiciales necesitan circular de un Estado a otro. El procedimiento diseñado por el legislador europeo para conseguir dicha finalidad se ha regulado en los Capítulos IV (en cuanto a las 
resoluciones judiciales) y $\mathrm{V}$ (por lo que respecta a los documentos públicos y transacciones judiciales), en un plano de total paralelismo entre ambos Reglamentos ${ }^{15}$.

Todo el sistema se articula en torno al principio básico de la confianza recíproca entre las diversas autoridades pertenecientes a los Estados que forman parte de la cooperación reforzada. Esto facilita al máximo el movimiento de la resolución, documento o transacción de un país a otro, y permite lograr lo que se ha dado en llamar "la quinta libertad comunitaria", o sea, la libre circulación de actos dentro del espacio judicial europeo.

Precisamente, se instaura el reconocimiento automático en sintonía con lo establecido en el resto de los Reglamentos europeos (respectivos art. 36.1).

Asimismo se reconoce la posibilidad, por parte del Estado miembro al que se solicita el reconocimiento, que se lleven a cabo dos tipos de controles: a título principal (de conformidad con el procedimiento previsto para la declaración de fuerza ejecutiva) y a título incidental.

Los motivos por los que se puede denegar el reconocimiento son los "clásicos":

a) por contrariedad manifiesta con el orden público del Estado miembro en el que se solicita el reconocimiento; b) en presencia de resoluciones dictadas en rebeldía, cuando no se haya notificado la demanda o documento equivalente en tiempo y forma, salvo que el demandado no hubiera agotado sus posibilidades de defensa por no recurrir en el caso de que hubiera podido hacerlo; c) si la resolución fuere inconciliable con una resolución dictada en un procedimiento entre las mismas partes en el Estado miembro en el que se solicita el reconocimiento; d) si la resolución fuere inconciliable con una resolución dictada con anterioridad en un litigio, en otro Estado miembro o en un tercer Estado, entre las mismas partes con el mismo objeto, cuando esta última resolución reúna las condiciones necesarias para su reconocimiento en el Estado miembro en el que se solicita el reconocimiento. (respectivos arts. 37).

15 Dada la limitación en la extensión del presente trabajo, me ceñiré al tema del reconocimiento y ejecución de las sentencias. 
Igualmente, los Reglamentos prescriben la imposibilidad de controlar la competencia de los órganos jurisdiccionales del Estado miembro de origen y de proceder a una revisión en cuanto al fondo de las resoluciones dictadas por los mismos (respectivos arts. 39 y 40).

En ningún caso los órganos jurisdiccionales del Estado miembro de destino se pueden convertir en una segunda instancia, estando sus posibilidades de control limitadas, única y exclusivamente, al examen formal de los documentos presentados y a la apreciación de los eventuales motivos de denegación arriba expuestos.

Para obtener la ejecución de la resolución en el Estado de destino es necesaria una previa declaración de fuerza ejecutiva, de la que las sentencias extranjeras carecen. Sobre este punto los Reglamentos gemelos han roto con las últimas tendencias de los Reglamentos europeos que han suprimido el exequatur a estos efectos (concretamente el Reglamento de Bruselas I bis 1215/2012). Para conseguir dicha declaración de ejecutoriedad bastará con presentar los documentos previstos en los respectivos arts. 45 ante las autoridades del Estado miembro requerido. Y al hacerlo, el exequatur será concedido, ex respectivos arts. 47 , y notificado tanto al solicitante como a la parte contra la que se haya solicitado la ejecución (respectivos arts. 48).

En esta fase el proceso se puede convertir en contradictorio, al abrirse la posibilidad de interponer recursos por cualquiera de las partes dentro del plazo de 30 días a partir de la oportuna notificación, ampliable a $60 \mathrm{si}$ la parte contra la que se solicita la ejecución estuviera domiciliada en un Estado distinto de aquel en el que se haya dictado la declaración de fuerza ejecutiva (respectivos arts. 49.3).

Al mismo tiempo, también la resolución dictada sobre el recurso puede ser impugnada.

Por último, la declaración de fuerza ejecutiva se podrá denegar o revocar basándose en los motivos de denegación expuestos para el reconocimiento (respectivos arts. 51).

Además, hay que señalar que las disposiciones contenidas en ambos Reglamentos sobre reconocimiento y ejecución de resoluciones judiciales se extienden también a los documentos expedidos por las autoridades que 
ejerzan sus competencias por delegación, de conformidad con la definición de "órgano jurisdiccional" del art. 3 de ambos textos reglamentarios ${ }^{16}$.

\section{VALORACIÓN FINAL}

Los flujos migratorios, la multiculturalidad y la facilidad para viajar de un lugar a otro del planeta son fenómenos que se imponen en la realidad social de nuestros días y que repercuten, decisivamente, en el ámbito de las relaciones familiares. Ante tales hechos el derecho reacciona, como no podía ser de otra manera, para dar respuesta a las problemáticas que plantean los nuevos retos sociales.

Sin restar valor a los enormes logros que los Reglamentos gemelos han llevado a la deseada armonización dentro del seno de la Unión Europea de una materia tan sensible, como es el Derecho de Familia, hay que señalar, no obstante, algunos puntos críticos o mejorables:

a) En el ámbito de aplicación de los respectivos Reglamentos podemos toparnos con los primeros problemas causados por el legislador europeo, pues al utilizar definiciones sumamente amplias tanto de lo que se entiende por "régimen económico matrimonial" y del concepto de "efectos patrimoniales de las uniones registradas", como del contenido de las exclusiones, será necesario llevar a cabo previamente una labor de calificación a nivel interno, con la complejidad que en no pocas ocasiones lleva aparejada dicha figura.

b) En cuanto a la determinación del órgano jurisdiccional competente para dirimir los eventuales litigios, el criterio de conexión utilizado en los respectivos arts. 4 y 5 resulta sumamente acertado ${ }^{17}$, así como la posibilidad de utilizar la

16 En ningún caso el reconocimiento y ejecución de resoluciones implica el reconocimiento del matrimonio o de la unión registrada que dio lugar a la resolución (Considerando 64 Reg. REM y 63 Reg. EPUR).

17 Téngase en cuenta que la concentración de asuntos puede alcanzar su máxima expresión en la esfera familiar cuando se utilice la prórroga de la competencia del art. 12.1 Reg. 
autonomía de la voluntad, aunque de forma limitada. Más complejo es el mecanismo excepcional de inhibición regulado en los arts. 9 de ambos Reglamentos. Conviene destacar asimismo que, finalmente, el legislador evidencia el deseo de establecer un sistema internacional completo, buscando la supresión íntegra de remisión a las normas nacionales en lo que a competencia se refiere y estableciendo un foro subsidiario y otro de necesidad.

c) Al igual que para la fijación de la competencia judicial, una de las principales novedades introducidas por los Reglamentos es la actuación de la autonomía de la voluntad de los miembros de la pareja para designar la ley aplicable.

Los puntos de conexión normalmente utilizados son la residencia habitual y la nacionalidad. Con respecto al primero, el legislador europeo sigue sin dar un concepto claro del mismo. En cuanto a la nacionalidad, se excluye de su ámbito de aplicación lo relativo a la doble nacionalidad. Ambas son lagunas que pueden conllevar inseguridad e incertidumbre jurídica. Conectando ambos aspectos, el de la competencia y el de la ley aplicable, se aprecia una clara tendencia a unificar el forum y el ius, lo que es muy de agradecer en el ámbito del Derecho de Familia, donde las cuestiones procesales y sustantivas están tan íntimamente unidas.

Bruselas II bis. En ese caso, las cuestiones relativas a la responsabilidad parental vinculadas a una demanda de separación, nulidad o divorcio de un matrimonio serían juzgadas por el mismo órgano jurisdiccional que conozca de aquella, (determinado según el art. 3 de dicho Reglamento), cuestiones a las que se añadiría lo relativo al derecho de alimentos (art. 3 del Reglamento 4/2009 en materia de obligaciones de alimentos), así como el reparto y liquidación de los bienes del matrimonio por imperativo del art. 5 Reg. REM. Para las uniones de hecho registradas no existe regulación europea para su disolución, por lo que habrá que estar, en principio, a la normativa interna o autónoma. No así para las obligaciones de alimentos a la luz del art. 4 del Reglamento 4/2009, que engloba tales obligaciones cuando derivan de una relación familiar, de parentesco, matrimonio o afinidad (Vargas Gómez-Urrutia, 2017, p. 323). 
d) Finalmente, en cuanto al reconocimiento y ejecución, se observa que el mantenimiento del exequatur puede suponer un retroceso en la aplicación práctica de los Reglamentos y pugna con la opinión legislativa favorable a su supresión desarrollada por el legislador comunitario en los últimos Reglamentos, aunque con diferentes matices e intensidades.

No obstante, por encima de todas estas apreciaciones, los Reglamentos examinados suponen la culminación de la comunitarización de todos los sectores del Derecho Internacional Privado de la Familia, Sucesiones y Obligaciones Alimenticias, sin dejar prácticamente resquicios regulatorios. Por ello es de esperar que las deficiencias y complejidades que presentan, la eventual descoordinación con otros Reglamentos sumamente relacionados con el aspecto patrimonial de las parejas (concretamente, el Reg. Bruselas II bis, el Reg. sobre sucesiones y el Reg. Roma III) e, incluso, las disfunciones que se aprecian dentro de los mismos (como es el caso de la desconexión del art. 26 con el art. 6 para fijar la residencia habitual y la nacionalidad en el Reg. REM), sean corregidas a través de una buena praxis por parte de todos los operadores jurídicos.

\section{BIBLIOGRAFÍA}

Álvarez González, Santiago. Orden público europeo versus orden público internacional de cada Estado. La gobernanza del interés público global, XXV Jornadas de Profesores de Derecho internacional y relaciones internacionales. Tecnos. Madrid, 2015.

Arenas García, Rafael. Principios inspiradores del sistema actual de competencia judicial internacional en materia de persona y familia, en Guzmán Zapater, Mónica Y Esplugues Mota, Carlos (Dirs.), Herranz Ballesteros, Mónica Y Vargas Gómez-Urrutia, Marina (coords.). Persona y familia en el nuevo modelo español de Derecho internacional privado. Tirant lo Blanch. Valencia, 2017.

Campuzano Díaz, Beatriz. La propuesta de reforma del Reglamento 2201/2003: ¿se introducen mejoras en la regulación de la competencia 
judicial internacional?, en Guzmán Zapater, Mónica Y Esplugues Mota, Carlos (Dirs.), Herranz Ballesteros, Mónica Y Vargas Gómez-Urrutia, Marina (coords.). Persona y familia en el nuevo modelo español de Derecho internacional privado. Tirant lo Blanch. Valencia, 2017.

Feraci, Ornella. L'incidenza del nuovo regime europeo in tema di rapporti patrimoniali tra coniugi e parti di unioni registrate sull'ordinamento giuridico italiano e le interazioni con le novità introdotte dal d.lgs. 7/2017 attuativo della cd. legge Cirinnà. Osservatorio sulle fonti, Fascículo 2. Florencia, 2017.

Fernández Rozas, José Carlos. Un hito más en la comunitarización del Derecho internacional privado: regímenes patrimoniales y efectos patrimoniales de las uniones registradas. La ley Unión Europea, $\mathrm{n}^{\mathrm{o}} 40$. Wolters Kluwer. Madrid, 2016.

Fernández Pérez, Alberto. Mediación familiar transfronteriza en el ámbito europeo. La ley Derecho de familia, $\mathrm{n}^{\circ}$ 17. Wolters Kluwer. Madrid, 2018.

Peiteado Mariscal, Pilar, Competencia internacional por conexión en materia de régimen económico matrimonial y de efectos patrimoniales de uniones registradas. Relación entre los Reglamentos UE 2201/2003, 650/2012 y 1104/2016. Cuadernos de Derecho Transnacional, Vol. 9, $\mathrm{n}^{\circ}$ 1. Universidad Carlos III: Área de Derecho Internacional Privado. Madrid, 2017.

Quinzá Redondo, Juan Pablo. "La unificación -fragmentada- del derecho internacional privado de la Unión Europea en materia de régimen económico matrimonial: el Reglamento 2016/1103. Revista General de Derecho Europeo, $n^{\circ}$ 41. Iustel. Madrid, 2017.

Quinzá Redondo, Juan Pablo. La cláusula de excepción del art. 26.3 del Reglamento 2016/1103 sobre régimen económico matrimonial, en Guzmán Zapater, Mónica y Esplugues Mota, Carlos (dirs.), Herranz Ballesteros, Mónica y Vargas Gómez-Urrutia, Marina (coords.). Persona y familia en el nuevo modelo español de Derecho internacional privado. Tirant lo Blanch. Valencia, 2017.

Quinzá Redondo, Juan Pablo y GRAY, Jacqueline. La (des) coordinación entre la propuesta de Reglamento de régimen económico matrimonial y 
los Reglamentos en materia de divorcio y sucesiones. Anuario Español de Derecho Internacional Privado, $\mathrm{n}^{\circ}$ 13. Iprolex. Madrid, 2013.

Rodriguez Benot, Andrés. La armonización del régimen económico matrimonial en la Unión Europea: la Propuesta de Reglamento de 2011, en Esplugues Mota, Carlos y Palao Moreno, Guillermo (eds.), Penadés Fons, Manuel (coord.). Nuevas fronteras del derecho de la Unión Europea. Tirant lo Blanch. Valencia, 2012.

Rodriguez Benot, Andrés. Los efectos patrimoniales de los matrimonios y de las uniones registradas en la Unión Europea. Cuadernos de Derecho Transnacional, Vol. 11, $\mathrm{n}^{\mathrm{o}}$ 1. Universidad Carlos III: Área de Derecho Internacional Privado. Madrid, 2019.

Rodríguez Vázquez, Ma . Ángeles. Una nueva fórmula para la supresión del exequátur en la reforma del Reglamento Bruselas I. Cuadernos de Derecho Transnacional, Vol. 6, $\mathrm{n}^{\circ}$ 1. Universidad Carlos III: Área de Derecho Internacional Privado. Madrid, 2014.

Vargas Gómez-Urrutia, Marina. El puzzle se complica. Efectos patrimoniales de las uniones registradas y Reglamento (UE) 2016/1104. Problemas de calificación y coordinación entre los instrumentos europeos conexos, en Guzmán Zapater, Mónica y Esplugues Mota, Carlos (dirs.), Herranz Ballesteros, Mónica y Vargas Gómez-Urrutia, Marina (coords.). Persona y familia en el nuevo modelo español de Derecho internacional privado. Tirant lo Blanch. Valencia, 2017.

Vinaixa MiqueL, Mónica. La autonomía de la voluntad en los recientes reglamentos UE en materia de regímenes económicos matrimoniales (2016/1103) y efectos patrimoniales de las uniones registradas (2016/1104). InDret, Universitat Pompeu Fabra, nº 2. Barcelona, 2017. 


\section{INTERVENCIONES EN Actos Académicos}





\section{Cien años de multilateralismo y Retos Para EL SEGUNDO CENTENARIO}

\section{Oscar Schiappa-Pietra Cubas*}

Agradezco a la Embajada de Suiza, al Instituto de Estudios Social Cristianos y a la Sociedad Peruana de Derecho Internacional por organizar este evento e invitarme como expositor.

Es especialmente significativo que estemos ahora congregados bajo la hospitalidad del Gobierno de Suiza, pues este país cumple un rol muy significativo promoviendo el multilateralismo. Ginebra, es reconocida como la capital mundial del multilateralismo, pues fue sede de la Sociedad de Naciones, y actualmente alberga a las sedes de alrededor de cuarenta organismos internacionales, incluyendo la sede europea de las Naciones Unidas, y de más de setecientas organizaciones no-gubernamentales.

El 8 de enero de 1918, precisamente cuando las tropas estadounidenses empezaban a revertir la correlación bélica de la Primera Guerra Mundial, el presidente Woodrow Wilson enunció sus propuestas para forjar un escenario internacional con vocación de paz, los célebres 14 puntos. En estos se plantearon fórmulas para zanjar diversas disputas territoriales y responder a las aspiraciones nacionales, en Europa; se abogó por acabar con el secretismo en las negociaciones y los acuerdos diplomáticos; se enunció la necesidad de promover el libre comercio, el desarme y la autodeterminación de los

Conferencia en el Conversatorio A Cien Años de la Creación de la Sociedad de Naciones. Retos y Oportunidades del Multilateralismo. Evento organizado por la Sociedad Peruana de Derecho Internacional (SPDI), la Embajada de Suiza en el Perú y el Instituto de Estudios Social Cristianos (IESC), el lunes 02 de diciembre de 2019 
pueblos; y, en el último punto, se propuso "[Que u]na asociación general de naciones debe ser formada bajo acuerdos específicos con el propósito de otorgar garantías mutuas de independencia política e integridad territorial, a estados grandes y pequeños por igual".

Con algo de ironía y escepticismo, pero sin contradecir el acierto de los 14 puntos de Wilson, el Primer Ministro francés, George Clemenceau, señaló: "Dios nos dio los Diez Mandamientos y los quebrantamos. Wilson nos da los Catorce Puntos. Veremos."

El revolucionario planteamiento contenido en el rubro final de los 14 puntos del presidente Wilson encontró eco: hace un siglo y pocas semanas más, el 28 de junio de 1919, se suscribió el Tratado de Versalles, que formalmente puso fin a la terrible devastación de la Primera Guerra Mundial, y que -a través de su parte primera, consagrada al establecimiento de la Sociedad de Naciones- sentó los cimientos pioneros del orden multilateral de gobernanza global que hemos heredado.

Esa guerra, y su transacción a través del Tratado de Versalles, transformaron radicalmente el mapa geopolítico del mundo. La impronta de este acuerdo internacional, particularmente en lo que respecta a su más importante hito -la creación de la Sociedad de Naciones- ha tenido enorme impacto durante el siglo XX, y sigue manteniéndolo hasta la actualidad.

Pero, antes de continuar, cabe reflexionar sobre por qué es importante el tema que nos convoca hoy. Lo es:

- $\quad$ porque el reto de la sostenibilidad humana se nutre de las promesas de convivencia pacífica, cooperación y solidaridad internacionales, democracia y derechos humanos, que son los postulados fundamentales del multilateralismo;

- $\quad$ porque los complejos problemas que afrontamos como especie humana y habitantes del Hogar Común, que es nuestro planeta, requieren de respuestas desde la gobernanza global que escapan a las competencias y capacidades de los estados aisladamente;

- $\quad y$, porque el multilateralismo es el más reciente pilar del sistema internacional que la humanidad ha venido forjando a lo largo de los últimos cuatro siglos. 
Como sabemos, se atribuye -algo imprecisamente- el origen del actual sistema de organización jurídico-política internacional a los dos tratados de paz de Osnabrück y Münster, firmados el 15 de mayo y 24 de octubre de 1648, es decir, a lo que comúnmente se denomina la Paz de Westfalia. Las premisas fundamentales del marco conceptual y ordenamiento político westfaliano son la preeminencia del Estado como actor internacional, su atributo de soberanía estatal, y la territorialidad.

Sibien esa racionalidad westfaliana posibilitó eliminar la conflictividad bélica generada por diferencias religiosas en el espacio europeo del siglo XVII, fue incapaz de crear condiciones de paz generalmente sostenibles.

Ya a través de la Primera Guerra Mundial, la humanidad se vio confrontada con su desbocada capacidad de destrucción, catalizada, aún de modo más brutal que antes, por las innovaciones que la revolución industrial introdujo en la tecnología militar. En esa malhadada confrontación, más de diez millones de vidas se perdieron, los daños materiales fueron cuantiosísimos, y cuatro imperios se extinguieron.

La comunidad internacional de inicios del siglo XX cayó en cuenta sobre su propia inhabilidad para contener las barbaries bélicas apelando exclusivamente a la voluntad soberana de los estados. Así pareció reconocerlo el mismo Primer Ministro George Clemenceau, cuando el 11 de noviembre de 1918, día de la firma del armisticio de la Primera Guerra Mundial, sostuvo: "Hemos ganado la guerra, y no sin dolor; ahora habrá que ganar la paz, y esto seguramente será más difícil”.

Los estados firmantes del Tratado de Versalles se comprometieron a forjar un orden internacional que dejara atrás la confrontación como impulso fundamental en las relaciones entre ellos, para dar paso a la cooperación y a la confianza mutua como nueva gramática de las relaciones internacionales. Con la participación de los países europeos y Estados Unidos, secundados por diecisiete de los veinte países latinoamericanos, se fundó la Sociedad de Naciones.

La eficacia de este pionero emprendimiento multilateral requiere ser evaluada en dos dimensiones temporales distintas. De un lado, en lo históricamente inmediato, la Sociedad de Naciones fracasó en crear 
condiciones políticas para una paz sostenible, y en otras áreas solo alcanzó limitadísima eficacia. El historiador Edward Hallett Carr, sostiene que este pionero proyecto multilateral adoleció por abrigar un idealismo arraigado en el liberalismo decimonónico, y que es aquí -en sus principios fundacionalesdonde estuvo la causa de su ineficacia. Según el mismo Carr, el yerro no radicó en los individuos; ni en el cambio en la postura de los Estados Unidos, cuyo Senado no aprobó la membresía de su país en la Sociedad de Naciones, pese a que su fundación estuvo inmensamente inspirada en la visión y el liderazgo del presidente Wilson.

La precaria paz internacional alcanzada a través del Tratado de Versalles y de la Sociedad de Naciones colapsó prontamente, teniendo como gran catalizador al caos económico internacional que signó la década de 1930. Este organismo fue incapaz de contener las ambiciones de potencias revisionistas en Europa y Asia, o de amenguar el espíritu de profunda humillación de Alemania.

En particular, las severísimas condiciones impuestas en el Tratado de Versalles a Alemania, como perdedora de la Primera Guerra Mundial, sirvieron como combustible para propagar el resentimiento dentro de su sociedad hacia el resto de la comunidad internacional, propiciando el surgimiento del nazismo y de su protagonismo en el desencadenamiento de la Segunda Guerra Mundial. Ya John Maynard Keynes, en su libro de 1919, Las consecuencias económicas de la paz, había llamado la atención sobre lo excesivamente gravosa de la obligación de reparaciones impuesta a Alemania por el Tratado de Versalles, augurando que ello originaría una nueva crisis europea.

Pese a sus evidentes limitaciones como organismo encargado de preservar la paz internacional, la Sociedad de Naciones alcanzó moderado éxito en lograr estabilizar la situación de nuevos estados; en proteger a minorías; y en facilitar la transformación formal de territorios colonizados en estados soberanos.

Pero, de otro lado, analizado el rol de la Sociedad de Naciones desde una perspectiva de largo plazo, es menester reconocer que sembró las semillas de la cultura y la práctica del multilateralismo, y que sirvió de inspirador referente para la formación de las Naciones Unidas, al acabar la Segunda 
Guerra Mundial. Especialmente relevante es la consagración de la paz como un objetivo global en el Tratado de Versalles y su implementación a través de la Sociedad de Naciones, a través de la pionera noción de seguridad colectiva. El artículo $11.1^{\circ}$ del Tratado de Versalles estipuló: "Se declara expresamente que toda guerra o amenaza de guerra, afecte directamente o no a uno de los miembros de la sociedad, interesa a la sociedad entera y que ésta debe adoptar las medidas adecuadas para salvaguardar eficazmente la paz de las naciones." Y el artículo $10^{\circ}$ consagró el principio de soberanía de los estados: "Los miembros de la sociedad se comprometen a respetar y a mantener contra toda agresión exterior la integridad territorial y la independencia política presente de todos los miembros de la sociedad."

En torno a la Sociedad de Naciones se establecieron una gran cantidad de comités, institutos y organizaciones a cargo de variados asuntos económicos, sociales, humanitarios y culturales. Entidades como la Organización Internacional del Trabajo, la Organización Mundial de la Salud, la UNESCO y el UNICEF, emergieron de la estructura institucional forjada por la Sociedad de Naciones, y cumplen hasta nuestros días un rol vital de cooperación internacional especializada. Mención especial merece la Corte Internacional de Justicia, cuya antecesora también fue parte del sistema de la Liga de Naciones.

La Segunda Guerra Mundial ha sido la confrontación bélica más destructiva en la historia de la humanidad: un estimado de 70 a 85 millones de personas, es decir alrededor de 3\% de la población mundial perdieron la vida, muchísimas de modos extremadamente crueles; Europa y Japón quedaron materialmente devastadas. Sobre esas cenizas, se forjó en 1945 las Naciones Unidas.

Los países vencedores de la Segunda Guerra Mundial prestaron especial atención en evitar repetir el principal error del Tratado de Versalles. Estados Unidos, en particular, estableció en 1948 un programa de asistencia masiva para la reconstrucción de Europa, el Plan Marshall, destinando el $11 \%$ de sus fondos para financiar la rehabilitación de Alemania Occidental.

En la Carta de las Naciones Unidas se reafirman los principios básicos de paz y cooperación internacional a través de la coexistencia pacífica entre 
estados; se reconoce la dignidad inherente a toda persona, condensada en el concepto de derechos humanos; se reitera el principio de seguridad colectiva, mejorando los mecanismos para su implementación y se establece, a través de su artículo $42^{\circ}$, la atribución de la Organización para actuar militarmente contra estados que pongan en peligro la paz mundial.

Las Naciones Unidas puede reivindicar el haber logrado la membrecía en su seno de la totalidad de los estados soberanos; su rol promotor de los derechos humanos y de los valores democráticos; su eficacia en guiar el proceso de descolonización a nivel global; su soporte en la afirmación y desarrollo del derecho internacional; y su liderazgo en la institucionalización de la cooperación internacional.

A la vez -hay que reconocerlo- la Carta de las Naciones Unidas consagra una estructura de gobernanza global defectuosa, particularmente en lo concerniente a su Consejo de Seguridad. A través de su artículo 27.3, la Carta otorga a cinco naciones, vencedoras en la Segunda Guerra Mundial, el privilegio de ejercer un derecho de veto, que contradice el principio de igualdad soberana de los estados, consagrado en el art. 2.1 ${ }^{\circ}$ de la misma Carta. Además de la disfuncionalidad históricamente aparejada por el ejercicio de tal derecho de veto, este órgano ejecutivo fundamental carece de sometimiento a elementales principios democráticos y expresa con gran crudeza el dominio hegemónico de las grandes potencias.

Y es que las Naciones Unidas no puede sustraerse de las dinámicas políticas de su tiempo. Su funcionamiento quedó reducido a la ineficacia en asuntos de seguridad internacional que afectaban intereses estratégicos de los dos hegemones del orden bipolar, como ha quedado sistemáticamente evidenciado en el desenvolvimiento del Consejo de Seguridad de las Naciones Unidas.

No obstante ello, hoy, coexistimos en un mundo más gobernable del que existía hace tres cuartos de siglo, teniendo la paz, la dignidad y bienestar personales, y el progreso social, inmensas mayores oportunidades de realización. A través de los 17 Objetivos de Desarrollo Sostenibles, la comunidad internacional comparte ahora una estrategia común para enfrentar algunos de los principales desafíos contemporáneos. Y, como lo ha anotado John Ruggie, el orden multilateral liderado por las Naciones Unidas 
ha posibilitado estabilizar las consecuencias generadas por la disolución de la bipolaridad.

Pero hay que decirlo con claridad: es igualmente cierto que los problemas que hoy afrontamos como humanidad vienen desbordando las capacidades de nuestros gobernantes, de nuestros diplomáticos y políticos, y de los organismos internacionales, para darles cara. Estamos dejando a las futuras generaciones un cúmulo de problemas sin resolver y de riesgos que demandan urgente atención. De cara a estos inmensos desafíos, necesitamos reflexionar sobre el nuevo perfil de multilateralismo que las realidades contemporáneas y futuras demandan.

Hacia tal rumbo, resulta fundamental dejar anotadas las debilidades del actual sistema multilateral. Una primera es el llamado déficit democrático. Cada vez más, las decisiones fundamentales sobre temas que afectan el bienestar y comprometen el futuro de cada uno de nosotros, los ciudadanos del mundo, vienen dejando de ser adoptadas en la esfera interna de cada Estado, y se convierten en competencia de instancias internacionales, públicas o privadas. Mientras todos elegimos mediante el voto a nuestras autoridades políticas nacionales, e influimos por diversos medios en las decisiones que ellas adoptan; nada parecido ocurre en la esfera internacional, donde muchísimas vitales decisiones son acordadas con poca transparencia, alejadas de medios de participación y de control ciudadanos, y sin que nuestras voces, intereses y puntos de vista sean tenidos en cuenta. Las tendencias globalizadoras acentúan cada vez más este déficit democrático. Las protestas sociales que en estos días asolan a muy diversos países en el mundo expresan el descontento popular ante esta progresiva erosión de los atributos ciudadanos.

Y hay que tomar conciencia que poco podrá avanzarse en superar este déficit democrático en la esfera multilateral si a la misma vez existe una notoria regresión en la observancia de los estándares de derechos humanos y de democracia por parte de los estados en el ámbito nacional. De un lado están los países sometidos a regímenes autoritarios, que vienen cobrando mayor protagonismo en el concierto de las naciones; pero, del otro, está la preocupante fatiga democrática y la pérdida de convicción en los dirigentes políticos y ciudadanos de los propios países que históricamente eran la 
vanguardia en la observancia y promoción de los valores de la libertad y la dignidad humanas.

La segunda área de debilidad del sistema multilateral está referida a su carácter descentralizado, y a la multiplicación y enorme diversificación que venimos experimentando en el universo de los actores internacionales. Esto dificulta la forja de consensos, y viene generando gran fragmentación en los mecanismos de gobernanza global, dada la poca coordinación existente entre ellos, al par que se multiplican las fuentes normativas, incluyendo la diversificación de las instancias judiciales internacionales. Tal fragmentación dificulta la capacidad para generar respuestas eficaces frente a desafíos que demandan soluciones holísticas y genuinamente globales.

La tercera área de debilidad la encontramos en la falta de consensos, que se expresa también en la ausencia de expresiones institucionales, para regular aspectos críticos de la convivencia y la sostenibilidad globales. Por ejemplo: el ciberespacio es hoy una dimensión fundamental de nuestras vidas, de cómo nos relacionamos con los demás, de cómo nos comunicamos e informamos, de cómo comerciamos. No obstante su centralidad en el quehacer cotidiano de la humanidad, el ciberespacio carece de mecanismos mínimamente eficaces para su gobernabilidad global. Esto viene generando inmensas distorsiones y nuevos riesgos, a través de la concentración monopólica privada a escala global por parte de unos pocos conglomerados, o de la masiva erosión de la privacidad, o del surgimiento de graves amenazas de ciberseguridad.

Peor aún, viene intensificándose el riesgo que el ciberespacio se convierta en un nuevo escenario en la creciente confrontación entre China y los Estados Unidos, generando así fragmentación en sus estructuras tecnológicas, haciéndolo vehículo de mutuas agresiones, y despojándolo de su vocación de libertad que tanto viene contribuyendo a ensanchar las fronteras de la creatividad humana. Thomas L. Friedman acaba de referirse a esto: "Pero nadie parecía darse cuenta que casi exactamente 30 años luego de la caída del Muro de Berlín, un nuevo muro -un Muro de Berlín digitalhabía empezado a construirse entre China y los Estados Unidos". (Friedman, 2019). 
Esta misma debilidad se proyecta, asimismo, en otras muchas esferas, como las de la gestión de la sostenibilidad medioambiental de nuestro Hogar Común; y de la lucha contra la criminalidad trasnacional, la corrupción y el lavado de dinero. En todos esos casos, las respuestas institucionales para su gobernanza multilateral son precarias e insuficientes.

De otro lado, como ya ha quedado señalado, el desenvolvimiento del multilateralismo está determinado por la realidad política global. Ahora estamos atravesando un proceso de profundos cambios, cuya evolución hacia el mediano plazo resulta incierta. Casi toda la segunda mitad del siglo $\mathrm{XX}$ estuvo signada por la competencia bipolar, que dio luego paso a una temporalmente efímera unipolaridad, y que en estos días va transformándose hacia la multipolaridad. La consiguiente competencia por hegemonía entre tres grandes potencias -Estados Unidos, China y en menor medida Rusiatorna muy complejo el escenario dentro del cual el multilateralismo tiene que redefinirse.

Todas estas reflexiones tienen un significado especial en estos días, cuando los ciudadanos en muy diversos países toman las calles para protestar. Es demasiado temprano para formular diagnósticos exhaustivos sobre sus motivaciones, pero en un nivel epidérmico es evidente que lo que esos hombres y mujeres de muy diversas latitudes están expresando son sus insatisfacciones con el desenvolvimiento de la democracia, tanto en sus dimensiones nacionales como multilaterales; de la globalización y de la gobernanza global. Ese descontento ciudadano no constituye novedad: este último fin de semana se han cumplido veinte años de las protestas contra la globalización que tuvieron lugar en Seattle, con ocasión de la Reunión Ministerial de la Organización Mundial del Comercio. Es pertinente recordarlo porque el funcionamiento de la $\mathrm{OMC}$ grafica nítidamente las virtudes pero también los defectos del multilateralismo, que es catalista de la globalización.

La OMC ha asumido, sin mayor control democrático y sin contar con el consenso de todos sus estados miembros, funciones regulatorias en una gran diversidad de áreas que en puridad no son de comercio internacional, y se ha tornado en promotora de la denominada hiperglobalización, erosionando a través de ese proceso la gobernanza democrática en las 
naciones, y los márgenes de autonomía de los gobiernos para promover sus propias políticas públicas. De los 242 casos resueltos por las instancias de solución de controversias de la OMC hasta hoy, solamente en 22 de ellos las políticas nacionales lograron prevalecer, no obstante que en muchas ocasiones los asuntos controvertidos no estaban en puridad referidos a cuestiones de comercio internacional. Y dentro de pocos días, el sistema de solución de controversias de la OMC quedará paralizado debido al bloqueo estadounidense a la nominación de nuevos integrantes para su Panel de Apelaciones.

Pero, las deficiencias del multilateralismo y del orden global en general no son meramente institucionales, sino que hunden sus raíces muy profundamente en nuestros marcos conceptuales. Las nociones de soberanía exclusiva y excluyente de los estados, la territorialidad, y diversas construcciones teóricas que reivindican la competencia de las superpotencias para afirmar su hegemonía, representan conceptualizaciones ineficaces y hasta contraproducentes para enfrentar los retos contemporáneos de la gobernanza global. A esas obsoletas categorías debemos contraponerles las emergentes nociones del derecho constitucional global, del derecho administrativo global; y el reconocimiento de la existencia de bienes y males públicos globales, cuya atención demanda la acción colectiva mundial.

Y es, al calor de estas emergentes categorías conceptuales, que tenemos que reformar el multilateralismo que legaremos a las nuevas generaciones. Este debe someterse a normas y mecanismos de control democrático, y debe brindar amplia cabida la participación ciudadana dentro de sus procesos de toma de decisión.

Tenemos una deuda histórica y ética con nuestro Hogar Común y con las futuras generaciones, de crear a través de un multilateralismo renovado condiciones de gobernanza global que respondan eficazmente a los retos actuales y futuros de la humanidad; que promuevan la convivencia solidaria y pacífica; que garanticen la sostenibilidad planetaria; que forjen una cultura de ciudadanía global; y que distribuyan equitativamente los frutos del bienestar que colectivamente vamos creando.

En suma, tenemos ante nosotros el desafiante reto de forjar un multilateralismo cuyo centro gravitacional sea la persona humana, y no la 
competencia hegemónica entre superpotencias ni el desbocado ejercicio de la soberanía estatal. Ese nuevo multilateralismo ineludiblemente tendrá que tener, para reclamarse legítimo y ser sostenible, un perfil democrático, participativo y transparente.

\section{BIBLIOGRAFÍA}

Bailey, T. (1957, junio). Woodrow Wilson Wouldn't Yield. American Heritage, 8(4), 20-25, 105-106.

Beaulac, S. (2004). The westphalian model in defining international law: Challenging the myth. Australian Journal of legal History, 8(2), $181-213$.

Bekkers, V., Dijkstra, G., Edwards, A. y Fenger M. (2007). Governance and the Democratic Deficit. Assessing the Democratic Legitimacy of Governance Practices. Aldershot: Ashgate.

Burke, A. y Parker, R., eds. (2017). Global Insecurity. Futures of Global Chaos and Governance. London: Palgrave Macmillan.

Carr, E.H. (2016). The Twenty Years' Crisis, 1919-1939. London: Palgrave Macmillan.

Casanovas La Rosa, O. O. (2019). En el centenario del tratado de Versalles. Revista Española de Derecho Internacional, 71(1), 17 - 22.

Clavin, P. (2013). Securing the World Economy. The Reinvention of the League of Nations, 1920-1946. Oxford: Oxford University Press.

Cox, M., Manning, D., Quah, D., Kitchen, N. $y$ Scholefield, S. (2015). $21^{\text {st }}$ Century Power. Dislocation, Diffusion and Decay. London: LSE Ideas.

Frey, M., Kunkel, S., y Unger C.R., eds. (2014). International Organizations and Development, 1945-1990. Houndsmill: Palgrave Macmillan.

Friedman, T. L. (2019, noviembre 26). The World-Shaking News That You're Missing. The New York Times, A: 23.

Grant, R.G. (2001). World War I. Armistice 1918. Austin: Raintree, Steck-Vaughn. 
Gros, L. (1948, enero). The Peace of Westphalia (1648-1948). The American Journal of International Law, 42(1), 20-41.

Hassan D. (2006). The Rise of the Territorial State and the Treaty of Westphalia. Yearbook of New Zealand Jurisprudence, 9, 62 - 70.

Hogan, M. J. (1987). The Marshall Plan. America, Britain, and the reconstruction of Western Europe, 1947-1952. Cambridge: Cambridge University Press.

Innerarity, D. y Solana, J., eds. (2013). Humanity at Risk. The Need for Global Governance. New York: Bloomsbury.

Keynes, J.M. (2019). The Economic Consequences of Peace. With a new introduction by Michael Cox. Cham: Palgrave Macmillan.

Lowry, B. (1996). Armistice 1918. Kent: The Kent State University Press.

Luard, E. (1982). A History of the United Nations. Volume 1: The Years of Western Domination, 1945-1955. London: Macmillan.

Luard, E. (1989). A History of the United Nations. Volume 2: The Age of Decolonization, 1955-1965. New York: Palgrave Macmillan.

MacMillan, M. (2002). Paris 1919. Six Months That Changed the World. New York: Random House.

McGlinchey, S. (2010, septiembre 08). E.H. Carr and the Failure of the League of Nations. E-International Relations. Visitado octubre 12, 2019, de www.e-ir-info/2010/09/08/e-h-carr.and.the-failure-of-the-league-ofnations-a-historical-overview/

McPherson, A. $y$ Wehrli, Y, eds. (2015). Beyond Geopolitics. New Histories of Latin America and the League of Nations. Alburqueque: New Mexico University Press.

Mingst, K.A. $y$ Karns, M.P. (2011). The United Nations in the 21 st Century. Boulder: Westview Press.

Moreland, W. (2019). The Purpose of Multilateralism. A Framework for Democracies in A Geopolitically Competitive World. Washington, D.C.: Brookings. 
Niemeyer, G. (1952, noviembre). The Balance-Sheet of the League Experiment. International Organization, 6(4), 537-558.

Osiander, A. (2001, primavera). Sovereignty, International Relations and the Westphalian Myth. International Organization, 55(2), 251 - 287.

Pedersen, S. (2007, octubre). Back to the League of Nations. American Historical review, 112(4), 1091 - 1117.

Pedersen, S. (2015) The Guardians. The League of Nations and the Crisis of Empire. New York: Oxford University Press.

Rosenbach, E. $y$ Mansted, K. (2019). The Geopolitics of Information

Cambridge: Harvard Kennedy School Belfer Center for Science and International Affairs.

Ruggie, J.G. (1992, verano). Multilateralism: the Anatomy of an Institution. International Organization, 46(3), 561-598.

Schain, M., ed. (2001). The Marshall Plan: Fifty Years After. New York: Palgrave.

Steil, B. (2018). The Marshall Plan. Dawn of the Cold War. New York: Simon \& Schuster.

Steiner, Z. (2005). The Lights That Failed. European International History 1919-1933. New York: Oxford University Press.

Straumann, B. (2008). The Peace of Westphalia as a Secular Constitution. Constellations, 15(2), $173-188$.

Weinberg, G. L. (1995). A World at Arms. A Global History of World War II. New York: Cambridge University Press.

Weiss, T.G. (2015) The United Nations: before, during and after 1945. International Affairs, 91(6), 1221-1235.

White, N.D. (2019). The legacy of the League of Nations: Continuity or change. Revista Española de Derecho Internacional, 71(2), 277-284. 



\section{Homenajes}





\title{
EMbajador Igor VelázQuez Rodríguez: Su legado perpetuo y ejemplar para el Perú
}

\author{
Oscar Maúrtua de Romaña*
}

\section{INTRODUCCIÓN}

Próximo a cumplirse 15 años de la penosa partida de nuestro querido amigo y colega Igor Velázquez Rodríguez (Lima, 27 de enero de 2005) y nueve años antes que la Corte Internacional de Justicia dictara el fallo sobre la controversia marítima entre Perú y Chile, debemos tenerlo siempre presente, pues fue un hombre, que, en honor al servicio a su país, adquirió y donó la sede permanente de la Academia Diplomática del Perú1; aquella, que, hasta fines del 2003, funcionaba en instalaciones alquiladas, sin que ningún miembro del Servicio Diplomático hubiese adoptado una actitud benefactora

Embajador y Jurista. Ingresó a Torre Tagle a los 18 años como empleado administrativo en 1965. Graduado de la Pontificia Universidad la Católica del Perú (PUCP) como Bachiller en Humanidades. Licenciado en Derecho (Abogado) de la Universidad Nacional Mayor de San Marcos (UNMSM). Licenciado en Relaciones Internacionales de la Academia Diplomática del Perú (1968). Premio Nacional de Cultura, 1969. Postgrados de las Universidades de Oxford, John Hopkins y Comité Jurídico Interamericano de la OEA. Magíster en Gestión Pública por la Universidad Tecnológica del Perú - UTP (2018). Presidente de la Sociedad Peruana de Derecho Internacional (SPDI). Secretario General de la Presidencia de la República (1980-1985). Director de la Academia Diplomática (2002-3003) Ex Vice Ministro y Secretario General de Relaciones Exteriores; y, ex Canciller de la República. Profesor e investigador.

Deseo dejar expreso reconocimiento a los Embajadores Julio Balbuena López Alfaro y Heli Peláez Castro, por sus generosos aportes a la elaboración del presente ensayo.

1 Bákula, Juan Miguel. (2006). El Perú en el reino ajeno. Historia interna de la acción externa. Universidad de Lima, 2004, p. 143. 
hacia el Alma Mater de la diplomacia peruana, tal cual como la asumida por Igor Velázquez Rodríguez, en una inédita acción. En reconocimiento por su importantísimo y noble gesto, se decidió nombrar a la Academia Diplomática del Perú “Embajador Igor Velázquez Rodríguez”, nombre que se mantuvo hasta el 2011, esto es, por más de siete años.

La razón es elemental y existe jurisprudencia: Prevaleció la costumbre - que es fuente de Derecho- de mantener el apellido, por gratitud, de quién efectúa un acto de liberalidad de tipo voluntario por el cual una persona dispone de parte de su patrimonio para la transferencia de manera gratuita en favor de un tercero ${ }^{2}$, como es el caso del Instituto Riva Agüero de la Universidad Católica (PUCP), la Fundación Canevaro, el hospital Larco Herrera, la Beca Prado de la Universidad Nacional Mayor de San Marcos (UNMSM), los Premios de la Fundación Manuel J. Bustamante de la Fuente, entre otros; en qué se ha respetado el nombre del legador, ya que es meramente manifestación de reconocimiento, con contenido axiológico.

Sin embargo, el legado de este ilustre diplomático peruano va más allá de la cesión de las instalaciones en las que hoy se forman los futuros embajadores del Perú en el mundo.

Igor Velázquez Rodríguez se inició, a muy corta edad, como ayudante quinto en el Ministerio de Relaciones Exteriores, lo que refleja su sentido de identidad y de pertenencia a la institucionalidad diplomática. A partir de ese momento, su carrera no hizo más que acumular logro tras logro, llegando a ser Representante Permanente del Perú ante las Organizaciones Internacionales con sede en Viena, Austria (Agencia Internacional de Energía Atómica - O.I.E.A.; Organización de las Naciones Unidas para el Desarrollo Industrial - O.N.U.D.I.; Comisión Preparatoria de la Organización para la Prohibición Total de Ensayos Nucleares, y; Acuerdo Regional de Cooperación para la Promoción de la Ciencia y la Tecnología

2 Estos son los sustentos de la donación. El autor consultó diversas fuentes, entre ellas: - Ghersi, Carlos A.; Weingarten, Celia (2017). «Contrato de donación». Manual de contratos civiles, comerciales y de consumo. Ciudad Autónoma de Buenos Aires: La Ley. p. 269. ISBN 978-987-03-3194-0.

- Castillo Freyre, Mario, “Tratado de los Contratos Típicos”, vol. XIX, tomo 1, cap. La donación, PUCP, Fondo Editorial, 2002, pág. 165. 
Nuclear en América Latina y el Caribe - ARCAL) y Embajador del Perú en países de Europa Central.

Considerado como un diplomático audaz, agudo, visionario, con capacidad para la negociación, pero sobre todo para anteponerse a distintos tipos de situaciones, con valentía y con claridad de ideas, no cabe duda de que Igor Velázquez Rodríguez supo defender y promover los intereses del país y llevar el nombre del Perú en todo lo alto, en el ejercicio de sus funciones diplomáticas y humanas.

Más aún, en un país como el nuestro, donde no abundan los actos de filantropía y en tiempos en que la autosuficiencia y el egoísmo marcan el devenir humano, acciones como la suya sobresalen, cuando no generan sorpresa, ante tan infrecuente desapego y altruismo.

\section{SUS INICIOS}

Igor Velázquez Rodríguez, nacido en Madrid el 25 de marzo de 1933, fue hijo del reconocido escritor y poeta piurano, Juan Luis Velázquez Guerrero (Piura, 26 de julio de 1903)³, así como de doña Dolores Rodríguez Zubillaga (Madrid, 3 de junio de 1914), notable empresaria y relacionista pública española. La pareja se separó a los pocos años de matrimonio y ella se asentó en el Perú. ${ }^{4}$

Sobre el padre de Igor, Juan Luis Velázquez Guerrero, cabe destacar que fue educado en el colegio la Inmaculada (SJ) en Lima y llegó a ser Doctor en Letras por la Universidad Nacional Mayor de San Marcos, siendo su primer poemario vanguardista El perfil de frente (1924), encomiado por Luis Alberto Sánchez, Jorge Basadre y José Carlos Mariátegui. Asimismo, mantuvo estrecha amistad con César Vallejo durante sus años en España y París, y fue amigo y colaborador cercano de Trotsky en México.

3 Milla Batres, Carlos (2004). Diccionario Biográfico del Perú Contemporáneo. Siglo $X X$. Tomo II (N-Z). Editorial Milla Batres, Lima, p. 442.

4 Enciso, Mary. (2015). Evocando al inolvidable Igor Velázquez. En "El Mirador". Publicado el 3 de febrero de 2015.

Página electrónica: https://elmirador.lamula.pe/2015/02/03/evocando-al-inolvidableigor-velasquez/encisopress/ 
Mirko Lauer calificó a Juan Luis Velázquez, como “incuestionable autor" apasionado de la síntesis, la misma que refleja en su primer libro: "El Perfil de Frente", obra que luego de aparecer, le hizo preguntarse ¿Puede haber algo más revelador en la búsqueda de la síntesis victoriosa, de la unidad reconquistada, que ese título? ${ }^{5}$

Agrega Raúl Moscol León, en Juan Luis, 31 años después: "Y es que los versos que forman parte de este poemario son breves. Unos tienen nombre, otros no y al final, el bardo ha escrito el mes y año de su inspiración, como el siguiente que data de noviembre del 23:

Ya me diste todo

quedando íntegra y pura.

Jamás perderé, aunque te pierda,

la eternidad de tu dulzura.

Ya no serás, como lo fuiste, mía y tuyo". 6

Moscol también nos relata que "Juan Luis admiraba a Albert Einstein. Lo llamó Héroe Contemporáneo. La Editora Libro-Mex de México publicó un libro que escribió sobre el creador de la Teoría de la Relatividad. También se nutrió de Buda, Guyau y Trotsky y pese a la gran amistad que cultivó con el líder soviético que vivió y fue asesinado en México, se alejó de los trotskistas 'cuando se disfrazaron como los únicos poseedores de una verdad mal digerida y peor administrada y mi comunismo halló su fin cuando lo vi vestirse de policía secreta'. [...] Y después de sentirse incapaz de 'vivir una fe militante y exclusivista', el poeta se convirtió en pintor 'porque sólo la pintura es capaz de decir todos los matices dentro de la armonía. Es el único arte unitario'. Optó, además, por el silencio y supo que era cierto aquello de 'Qué soledad sin soledad siquiera', versos que llevan el nombre de 'Piura', borroneados en marzo de 1924, que recuerdan a la "gente tan llena de recodos/enlodados en este desierto sin lluvias / ni rastrojos." 7

\footnotetext{
$5 \quad$ Raúl F. Moscol León. (2001). Juan Luis, 31 años después. Artículo publicado en el Diario Correo de Piura, el 25 de agosto de 2001. Ver en Literatura Piurana: http:// rafemole-literaturapiurana.blogspot.com/2008/12/juan-luis-velazquez-31-aosdespues.html Ibídem. Ibídem.
} 
Cabe indicar, además, que la hermana de Igor, Sonia Velázquez Rodríguez, se casó con el Embajador Jaime Cacho Souza Castro. Son sus sobrinos carnales de Igor, los hijos de dicha unión, los actuales Embajadores Jaime y Manuel Cacho Souza Velázquez.

Igor Velázquez Rodríguez, realizó sus estudios escolares primarios en el Colegio Anglo-Peruano (Perú) y los secundarios en el Liceo FrancoMexicano (México) y en el Colegio La Salle (Perú). Heredó de sus padres una exigente sintaxis y una pulcra redacción, con sindéresis y fino uso gramatical. Hablaba perfectamente inglés, francés, alemán, checo, húngaro y varios otros idiomas.

Asimismo, finalizando la secundaria, Igor Velázquez Rodríguez decidió ser médico, por lo que optó por entrar a San Fernando, la facultad de Medicina de la Universidad Nacional Mayor de San Marcos - UNMSM. No obstante, no pudo finalizar sus estudios, los cuales solo duraron dos años, debido a que dicha casa de estudios fue clausurada por razones políticas.

\section{DE SU TRAYECTORIA DIPLOMÁTICA}

Luego del cierre de la Facultad de Medicina de San Marcos, es el momento en donde se inicia la inmersión de Igor en el Servicio Diplomático del Perú. Julio Salazar, su íntimo amigo, hace un recuento de cómo fue el verdadero inicio de su vida diplomática, señalando que su padrastro, médico de cabecera del Presidente del Perú en la época, el General Manuel A. Odría, teniendo en consideración el mensaje que le había transmitido su señora esposa Doña Dolores Rodríguez, sobre las aspiraciones que tenía su menor hijo Igor para ser diplomático, se lo comunicó al Jefe de Estado, obteniendo el padrastro, una respuesta positiva. ${ }^{8}$

De esta manera es que Odría llamó al Canciller interino de la época, Eduardo Miranda Sousa, titular del despacho del Fomento, para que se agende la incorporación del joven Igor Velázquez Rodríguez al Ministerio de Relaciones

8 Salazar, Julio. (2008). En Recuerdo de un amigo. En revista "Política Internacional", revista de la Academia Diplomática del Perú. Lima 2008. 
Exteriores. Sin embargo, transcurrió un prudencial periodo de tiempo, tres meses, y la llamada nunca se hizo realidad. Al parecer la negativa del Canciller para hacer caso al pedido del Presidente Odría, se sustentaba en la corta edad que tenía Igor en ese entonces, la cual no sobrepasaba los 20 años. A insistencias del Presidente, es que Igor Velázquez, por fin, hace su entrada al Ministerio de Relaciones Exteriores, como ayudante quinto, el 17 de setiembre de 1952, estando de Canciller, don Ricardo Rivera Schreiber; y, el 20 de julio de 1953, se inscribe en el Escalafón del Servicio Diplomático del Perú.

Es así que se dio inicio a la larga trayectoria diplomática de Igor Velázquez Rodríguez: Tercer Secretario, mediante R.S. No 312 del 20 de julio de 1953; Segundo Secretario, a través de la R.S. № 287 del 1 de abril de 1961; Primer Secretario, por R.S. N ${ }^{\circ} 56$ del 28 de enero de 1966; Consejero, mediante R.S. $N^{\circ} 0001$ del 1 de enero de 1970; Ministro, a través de la R.S. $N^{\circ} 0001$ del 1 de enero de 1973; y, Embajador, por R.S. № 0703 del 9 de diciembre de 1977.

Debido a su agudeza, perspicacia y dotes para la negociación, cualidades imprescindibles para un diplomático, Igor fue asumiendo altas funciones y responsabilidades -luego de varios años de servicio- como "Encargado de Negocios a.i. del Perú" en Estados Unidos y en Chile. Uno de sus más destacados logros, desempeñando sus funciones en Washington D.C., fue impedir que se le aplicaran al Perú "Enmiendas" (represalias económicas que portan los nombres de los Congresistas norteamericanos que las proponen y que afectan la asistencia estadounidense en una Nación que según ellos perjudica los intereses de E.E.U.U.) llevadas a cabo por el gobierno norteamericano, tales como la Hickenlooper, Pelly, Comte y la PL 480, sustentándose en las expropiaciones que había realizado el gobierno militar del Perú en los años 70's; asimismo, evitó que atuneros californianos violaran la soberanía de las 200 millas del Perú. ${ }^{9}$

Cuando ascendió a la categoría de Embajador, Igor Velázquez, quien se preocupaba constantemente por el futuro institucional, y siendo Director de Personal de la Cancillería, se empeñó en encontrar una solución al grado profesional que nos otorgaba la Academia Diplomática, que era de "Diplomático de Carrera". Tras diversas y persistentes gestiones ante la

Enciso, Mary. Ibídem 
Asamblea Nacional de Rectores (ANR), logró que se otorgue el título de Licenciado en Relaciones Internacionales, promoviendo legalmente que tal formalización académica se confiera también, con efecto retroactivo, a las generaciones precedentes.

También puedo dar testimonio de su caballerosidad con el Presidente Fernando Belaunde y su esposa Violeta Correa de Belaunde, cuando éste se hallaba exiliado en Washington D.C., modales democráticos y de respeto que no practicaron otros representantes diplomáticos peruanos en los Estados Unidos.

Asimismo, ejerció funciones como Embajador del Perú en cuatro países de Europa central, siendo estos, Hungría, Polonia, Checoslovaquia y Austria (donde simultáneamente se desempeñó como Embajador no Residente del Perú ante el Gobierno de Turquía).

Posteriormente, fue designado Representante Permanente del Perú ante los Organismos Internacionales con sede en Viena, siendo también Presidente del Grupo Latinoamericano y del Caribe (GRULAC), en los que desempeñó una extraordinaria labor en personificación de los intereses del Perú. Admiraba a Cancilleres -con quienes había colaborado de cerca- como Carlos García Bedoya, José de la Puente Rabdill, Arturo García y García; así como a Embajadores como Jorge Guillermo Llosa Pautrat, Luis Marchand Stens, Carlos Alzamora, Fernando Berckemeyer y Celso Pastor de La Torre.

No cabe duda, que Igor Velázquez Rodríguez fue una de las figuras más representativas de la diplomacia peruana, dejando en claro las habilidades imprescindibles para desempeñar las funciones que amerita ser miembro del Servicio Diplomático: patriotismo; inteligencia; honradez; lealtad; elegante talante; entre otras virtudes.

\section{LEGADO Y RECONOCIMIENTOS}

Es de conocimiento público, que, hasta fines del 2003, la Academia Diplomática del Perú, no contaba con un local propio. La realidad cambió a inicios del 2004 cuando Igor Velázquez Rodríguez, en reconocimiento al honor de haber servido a su Patria, decide ex profesamente comprar y ceder las acciones y derechos de las instalaciones de un inmueble ubicado en 
San Isidro (esquina de Av. Pershing $\mathrm{N}^{\circ} 335$ y calle Ugarte y Moscoso $\mathrm{N}^{\circ}$ $101)^{10}$, para ser la actual sede permanente de la Academia Diplomática del Perú. Fui testigo de ese ejemplar gesto, por encontrarme como Director de dicha institución de formación profesional. De esta manera, Igor permitía que los futuros representantes del país puedan forjarse académicamente en instalaciones idóneas y propias para con las funciones que la Academia lleva a cabo. Esta acción, es un legado invaluable, propio de un hombre con valores y principios, pero sobre todo con un amor manifiesto por su patria y por la institución que lo acogió y a la que consagró más de medio siglo de su vida.

En agradecimiento a la importante donación, las Asociaciones de Funcionarios Diplomáticos del Perú (AFSDP), en actividad (AFDA) y en retiro (AFDR) -esto es, todo el Servicio Diplomático-, manifestaron su concordancia de que la Academia Diplomática del Perú lleve su nombre. Entonces, por disposición de la Resolución Ministerial No ${ }^{\circ}$ 435/RE del 4 de junio de $2004^{11}$, se agradece la donación de una sede permanente y se resuelve que la Academia Diplomática del Perú lleve el nombre de "Igor Velázquez Rodríguez". ${ }^{12}$

Posteriormente, esta decisión de denominar a la Academia Diplomática "Igor Velázquez Rodríguez", fue ratificada mediante Resolución Suprema $\mathrm{N}^{\circ}$ 297-2005-RE del 24 de noviembre de 2005, la cual lleva la firma del Presidente Constitucional de la República y del suscrito, como Ministro de Estado en el despacho de Relaciones Exteriores. Asimismo, el Gobierno ya le había concedido la Orden del Sol del Perú, en el grado de Gran Cruz, el 25 de junio de 2004, como reconocimiento a su trayectoria profesional. ${ }^{13}$

$10 \quad$ Dicha donación fue anunciada mediante Carta del 24 de marzo de 2004, dirigida al entonces Ministro de Relaciones Exteriores, Embajador Manuel Rodríguez Cuadros.

11 Modificada en su séptimo Considerando por la Resolución Ministerial N 0496/RE del 30 de junio de 2004.

12 También es sabido que el Presidente del Consejo de Ministros, Armando Villanueva del Campo en más de una oportunidad le ofreció ser nombrado como Viceministro Secretario General de Relaciones Exteriores, esto es Jefe Servicio Diplomático de la Republica, lo que Igor Velázquez no se decidió en aceptar, recordando el pensamiento hegeliano:" ... de que sea yo bueno y los demás mejores que yo", lo que reafirma su vocación institucional y la sencillez de su alma.

13 Cabe resaltar que mucho antes, a fines de la década de los 70's, el Ministro de 
A pesar de estos títulos y reconocimientos, en el 2011, siete años más tarde, a iniciativa del Embajador Harry Belevan $\mathrm{McBride}^{14}$, el Presidente de la República, Alan García Pérez, junto con el Canciller José Antonio García Belaunde, poco antes de terminar su mandato, deciden, mediante Resolución Suprema N¹36-2011-RE del 20 de abril de 2011, modificar el nombre de la Academia Diplomática del Perú, que, desde entonces, llevaría el nombre del ilustre diplomático, ex Secretario General de las Naciones Unidas, "Javier Pérez de Cuéllar".

Naturalmente, la decisión acarreó un sinfín de opiniones diversas, a favor y en contra del cambio de nombre, creando desazón y frustración entre quienes habíamos contribuido a reconocer tan plausible identidad con nuestra Alma Mater. El bien inmueble prevaleció con la denominación de "Casa Embajador Igor Velázquez Rodríguez".

Sin embargo, es imprescindible nunca olvidar al hombre que le donó una sede permanente y con prestancia a la Academia Diplomática del Perú, quien no lo hizo por buscar algún reconocimiento, sino por la honra y gratitud de haber podido servir a su Patria, incluso después de su muerte. En tal tesitura, Mery Enciso en su artículo "Evocando al inolvidable Igor Velázquez"15, cita las nobles y elocuentes palabras - que aún perduran- del ex Canciller Manuel Rodríguez Cuadros en su sepelio: “Él fue un diplomático por vocación, por función, por identidad. Una suerte de diplomático ontológico en el sentido que siempre asumió su misión personal, familiar y

Relaciones Exteriores, Embajador Carlos García Bedoya, lo había nombrado Presidente de su Comité de Asesores y luego fue condecorado con la Orden "Al Mérito por Servicios Distinguidos en Grado de Gran Cruz" (RS. Nº 0041 del 17 de enero de 1979). Asimismo, a nivel internacional, recibió las siguientes condecoraciones: Orden "Bernardo O’Higgins" en el Grado de Gran Cruz - Chile (1979); Orden "Del Águila Azteca" en el grado de Placa - México (1980); y, Orden "De Mayo Al Mérito" en el Grado de Gran Oficial - Argentina (1980), entre otras.

14 Según él mismo lo ha afirmado en una entrevista para el diario La República, el 5 de marzo de 2020, la que está disponible en: https://larepublica.pe/politica/2020/03/06/ javier-perez-de-cuellar-soy-un-producto-de-torre-tagle-quimicamente-puro/ Enciso, Mary. (2015). Evocando al inolvidable Igor Velázquez. En “El Mirador". Publicado el 3 de febrero de 2015.

Página electrónica: https://elmirador.lamula.pe/2015/02/03/evocando-al-inolvidableigor-velasquez/encisopress/ 
como ciudadano a partir de su desempeño como Embajador del Perú y como miembro del Servicio Diplomático".

Todo esto coincide y se engarza con la doctrina de Abraham Maslow ${ }^{16}$ quien en su pirámide considera en la cima de la misma, la autorrealización; es decir, el honor.

Su filantropía no se limitó a su donativo para la sede de la Academia Diplomática, sino fue también en memoria a su madre, doña Dolores Rodríguez Zubillaga (16-02-1993) que donó, igualmente, una fuente en el corazón de San Isidro, en la intersección de las avenidas Miguel Dasso y Cavenecia, en homenaje a la madre peruana; a la vez que aportó discretamente sendas subvenciones a viudas de colegas diplomáticos que no atravesaban buena situación financiera. Similar filantropía realizó con la construcción de una sede en Chilca para acoger a personas humildes. Lo revelo porque han habido trascendidos, ya que a él no le hubiera agradado que fuera de conocimiento público dado su fino talante.

Estoy persuadido, que el amor de Igor por el Servicio Diplomático y su personalidad, encajan perfectamente en el concepto español de caballero y que en el vocablo ingles se expresa como un "gentleman"; esto es, el hombre valeroso que no daña, que no perjudica a nadie, que no odia, sino que se consagra por sus valores, y señorío. Y esa es la estela que nos deja este entrañable, inteligente, desinteresado amigo y colega a quien recordamos constantemente.

Todos los años, hace ya quince, los amigos leales a Igor Velázquez Rodríguez, llevamos a cabo una romería al cementerio donde descansan sus restos y nos congregamos en una cofradía para evocar al proverbial donante con afecto, respeto y admiración, seguros que su personalidad icónica trasciende para las nuevas generaciones de peruanos, que deben conocer de su desprendimiento y grandeza humana, ya que se ha convertido Igor en leyenda de la memoria colectiva del Perú.

Enero de 2020

16 Maslow, Abraham. (1973). A Theory of Human Motivation. Página electrónica: https://books.google.es/books?id=vdvXOxzbiNwC\&hl=es 


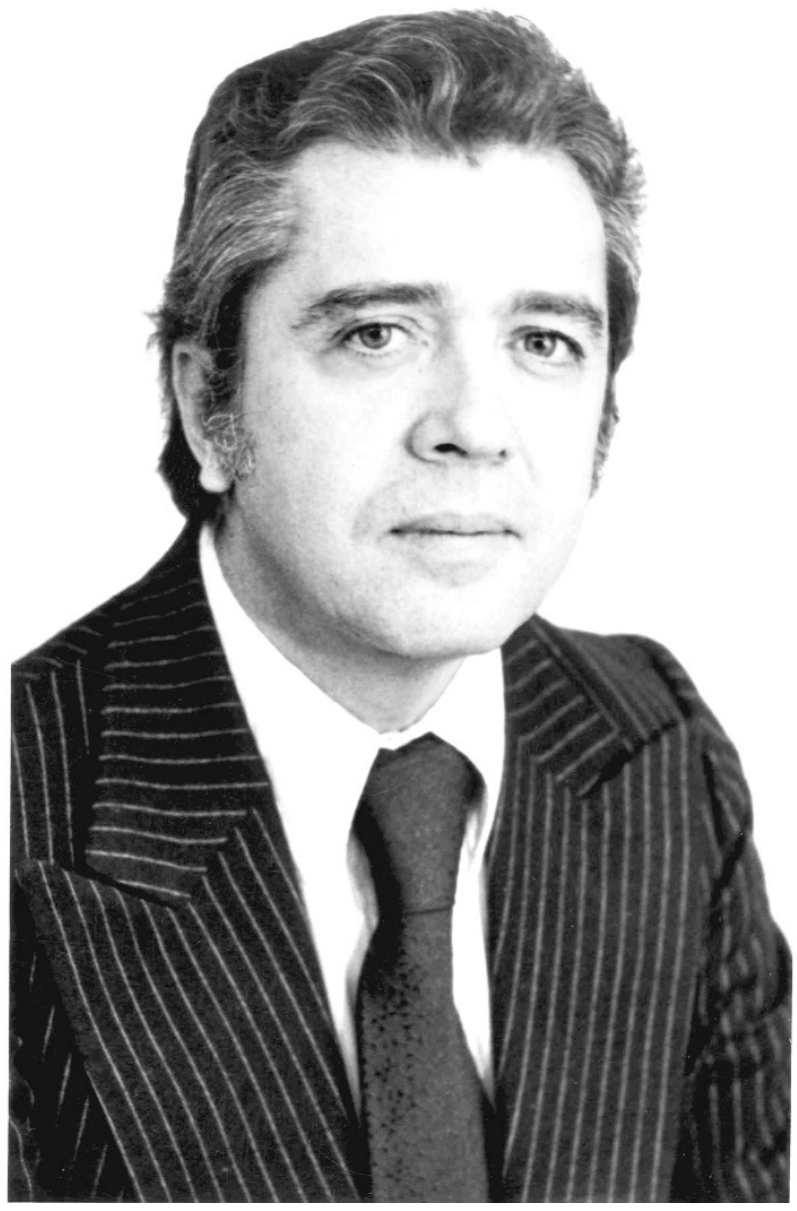

Igor Velázquez Rodríguez

(Madrid 1933 - Lima 2005) 



\section{BIBLIOGRAFÍA}

Bákula, Juan Miguel. (2006). El Perú en el reino ajeno. Historia interna de la acción externa. Universidad de Lima, 2004, p. 143.

Castillo Freyre, Mario, “Tratado de los Contratos Típicos”, vol. XIX, tomo 1, cap. La donación, PUCP, Fondo Editorial, 2002, pág. 165.

Enciso, Mary. (2015). Evocando al inolvidable Igor Velázquez. En "El Mirador". Publicado el 3 de febrero de 2015. Página electrónica: https:// elmirador.lamula.pe/2015/02/03/evocando-al-inolvidable-igor-velasquez/ encisopress/

Ghersi, Carlos A.; Weingarten, Celia (2017). «Contrato de donación». Manual de contratos civiles, comerciales y de consumo. Ciudad Autónoma de Buenos Aires: La Ley. p. 269. ISBN 978-987-03-3194-0.

Maslow, Abraham. (1973). A Theory of Human Motivation. Página electrónica: https://books.google.es/books?id=vdvXOxzbiNwC\&hl=es

Milla Batres, Carlos (2004). Diccionario Biográfico del Perú Contemporáneo. Siglo XX. Tomo II (N-Z). Editorial Milla Batres, Lima, p. 442.

Moscol León, Raúl F. (2001). Juan Luis, 31 años después. Artículo publicado en el Diario Correo de Piura, el 25 de agosto de 2001. Ver en Literatura Piurana: http://rafemole-literaturapiurana.blogspot.com/2008/12/juan-luisvelazquez-31-aos-despues.html

Resolución Ministerial Nº496/RE del 30 de junio de 2004.

Salazar, Julio. (2008). En Recuerdo de un amigo. En revista "Política Internacional", revista de la Academia Diplomática del Perú. Lima 2008.

El presente texto se elaboró en ocasión del 15 aniversario del fallecimiento de Igor Velázquez Rodríguez y que fue impreso para tal oportunidad. 



\title{
Homenaje al Embajador Javier Pérez de Cuéllar Cien años al Servicio del Perú y de la Justicia
}

\author{
Juan Alvarez Vita*
}

El Perú, a lo largo de su historia, ha tenido siempre hombres y mujeres que han destacado en los campos más variados de la actividad humana. En la esfera de la diplomacia, Javier Pérez de Cuéllar, sin duda alguna, ocupa un lugar muy singular por el hecho no solo de haber realizado una muy exitosa carrera en su condición de diplomático peruano, sino que, en el ámbito universal llegó a dirigir el destino de la Organización de las Naciones Unidas de la que fue su quinto Secretario General y, al término de su mandato, reelegido para un período más.

Las presentes líneas de homenaje tienen su origen en la invitación que me formuló el Presidente de la Sociedad Peruana de Derecho Internacional, embajador Oscar Maúrtua de Romaña, para conmemorar el centenario de su

\footnotetext{
Embajador de carrera del Perú. Lingüista e historiador. Estudió Derecho e Historia en la Universidad Nacional Mayor de San Marcos (UNMSM) y Pontificia Universidad Católica del Perú (PUCP); y Diplomacia en las Academias Diplomáticas del Perú y de Austria. Tiene los grados de Maestría y Doctor calificados con Summa cum laude. Representó al Perú en la Argentina, Hungría, Austria, Suiza, Naciones Unidas, Asociación Latinoamericana de Integración (ALADI), Costa Rica, Cuba, Indonesia, Timor Oriental y la Asociación de Estados del Sudeste Asiático (ASEAN). Ha sido presidente de la delegación del Perú ante la Comisión de Derechos Humanos de la Organización de las Naciones Unidas (ONU). A título personal, integró el Comité de Derechos Económicos, Sociales y Culturales, el órgano más importante de la ONU encargado de supervisar esos derechos humanos. Profesor universitario en el Perú y en la Universidad de Derechos Humanos de Ginebra (Suiza) en la que integra su Consejo Científico. Autor de 12 libros de carácter histórico, lingüístico y jurídico. Cabe destacar su obra titulada Diccionario de Peruanismos. El habla Castellana del Perú. Miembro Titular de la Sociedad Peruana de Derecho Internacional.
} 
nacimiento ocurrido en Lima el 19 de enero de 1920. Pocos días después de esta celebración, el 4 de marzo de 2020, expiraba el embajador Pérez de Cuéllar. La noticia de su fallecimiento, en su residencia en el barrio de San Isidro de la capital peruana, llenó las páginas de todos los diarios del país. La prensa internacional también destacó este suceso. Fueron muchísimos los mensajes de condolencias dirigidos a los familiares y a las autoridades peruanas. Al enviado por el Papa Francisco siguieron muchos otros de jefes de Estado y de otras personalidades de diferentes países. Excelentes artículos de plumas destacadas pusieron en relieve las altas cualidades que Pérez de Cuéllar tuvo en vida. Fue así como, bajo el impacto de estos dos acontecimientos inherentes a la condición humana, la conmemoración de su centenario y su fallecimiento, he escrito estas líneas en honor al colega y, más que al colega, al buen amigo, al hombre justo y probo.

El centro histórico de Lima fue el escenario físico donde transcurrió gran parte de su vida en el Perú pues su formación escolar la realizó en el Colegio de San Agustín, ubicado en aquel entonces en el convento de esa congregación religiosa católica romana. Luego ingresó a la Pontificia Universidad Católica del Perú, establecida no muy lejos de su antiguo colegio. Ahí cursó sus estudios en la Facultad de Letras y posteriormente en la de Derecho. Tan solo a pocas cuadras de esa universidad se alza el Palacio de los Marqueses de Torre Tagle, sede del Ministerio de Relaciones Exteriores del Perú, donde a partir de 1940 inició sus primeras prácticas profesionales. En 1944 ingresó al Servicio Diplomático y poco después iniciaba sus funciones en el exterior como secretario de las embajadas del Perú en Francia, Reino Unido de Gran Bretaña e Irlanda del Norte, Bolivia y Brasil. Posteriormente sería nombrado Consejero en esta última embajada donde fue promovido a la categoría de Ministro Consejero.

En 1961 ascendió a la categoría de embajador y como tal tuvo sucesivamente los cargos de jefe del Departamento Jurídico, Director de Personal, Director de Protocolo y Director de Asuntos Políticos. En 1966 fue nombrado Secretario General de Relaciones Exteriores, cargo que hoy equivale al de Viceministro.

Como embajador, Javier Pérez de Cuéllar se desempeñó como tal ante la Confederación Helvética, la entonces Unión Soviética, Polonia 
y Venezuela. Entre 1971 y 1975 lo encontramos como Representante Permanente del Perú ante la Organización de las Naciones Unidas. En ese período presidió las delegaciones de nuestro país en todas las sesiones de la Asamblea General de ese organismo que es el más importante del mundo.

El embajador Pérez de Cuéllar fue también representante del Perú ante el Consejo de Seguridad de la ONU cuya presidencia ejerció, con gran maestría, durante los complejos sucesos de Chipre en julio de 1974. En febrero de 1979 fue nombrado Secretario General Adjunto de las Naciones Unidas para Asuntos Políticos Específicos.

La elección del Secretario General de las Naciones Unidas es, por naturaleza, un proceso muy difícil pues el candidato debe tener condiciones muy especiales para hacerse merecedor de la confianza de sus electores pues debe obtener el consenso de los cinco miembros permanentes del Consejo de Seguridad. Pérez de Cuéllar lo consiguió y el 1 de enero de 1982 asumió ese alto cargo. El 10 de octubre de 1986 fue elegido para un segundo mandato que se inició el 1 de enero de 1987. En este nuevo período las Fuerzas de Paz de la ONU, más conocidas como los Cascos Azules, recibieron en 1988 el premio Nobel de la Paz.

Luego de concluidas sus funciones como Secretario General de las Naciones Unidas, ese mismo organismo y la Unesco lo designaron presidente de la Comisión Mundial de Cultura y Desarrollo con sede en París.

Pérez de Cuéllar nos ha dejado un legado escrito que merece tenerse en cuenta. Su "Manual de Derecho Diplomático", publicado en 1964, corregido y aumentado en una segunda edición en 1998, no solo es una guía importante para toda persona interesada en el quehacer internacional, sino que la comparación de ambas ediciones, permite apreciar la evolución de ciertas prácticas diplomáticas en los últimos años.

Otras obras, publicadas en su condición de Secretario General de las Naciones Unidas, constituyen valiosos testimonios de su accionar en ese importante cargo. Cabe mencionar "Peregrinaje por la Paz", editado originalmente en inglés. También su "Selección de Discursos" constituye una remarcable contribución para conocer el mundo profundo -la mayoría de las veces incomprensible para el profano- del ejercicio de la diplomacia. 
Ya en su avanzada ancianidad sorprendió a todos con la publicación de una novela que intituló "Los Andagoya". Vale la pena recoger, al respecto, la opinión de Fernando Carvallo: El lector cierra el libro y siente gratitud por el cuidado que Javier Pérez de Cuéllar ha prestado al lenguaje durante su larga vida. Al servicio de la paz en su brillante carrera de diplomático. Al servicio de la audacia de vivir con lucidez en su obra de novelista.

Pérez de Cuéllar recibió en vida muchos homenajes y condecoraciones. La colección de éstas fue un legado que en vida hizo a la cancillería peruana y que hoy se luce en un lugar preferencial de la Academia Diplomática del Perú que lleva su nombre.

Con motivo de su fallecimiento, el presidente de la Sociedad Peruana de Derecho Internacional, embajador Oscar Maúrtua de Romaña, en nota necrológica intitulada Javier Pérez de Cuéllar: El Perú y Latinoamérica han perdido a un diplomático excepcional y el mundo a un internacionalista que luchó por la paz y la dignidad global -que fuera publicada en el blog institucional y difundida por la agencia de noticias Reuter- señaló lo siguiente: "Respecto a su vínculo con la Sociedad Peruana de Derecho Internacional (SPDI), el 4 de mayo de 1962 don Javier Pérez de Cuéllar fue designado Miembro Asociado de la Institución, y el 15 de diciembre de 1966 fue promovido a la categoría de Miembro Titular. En la sesión del Consejo Directivo de la Sociedad, de fecha 7 de diciembre de 1989, se acordó por unanimidad designar Miembro Honorario al Embajador Pérez de Cuéllar. Asimismo, durante mi actual gestión como Presidente de la SPDI, se acordó por unanimidad, el 28 de setiembre de 2017, designar a don Javier Pérez de Cuéllar, Miembro del Consejo de Honor de la Institución".

Pérez de Cuéllar nunca estuvo alejado del Perú. Durante su gestión como Secretario General de la ONU surgió el problema de los llamados desplazados internos que, como consecuencia de la violencia desatada principalmente en los Andes Centrales de Huancavelica y Ayacucho, se habían visto obligados a abandonar sus lugares de residencia y migrar, principalmente, a las ciudades de la costa. La legislación internacional tenía en cuenta únicamente a los refugiados, es decir, a quienes huyen de un país a otro, pero no consideraba el caso de las personas que se trasladaban dentro de la jurisdicción de un mismo Estado. Durante su mandato las oficinas 
encargadas de los aspectos jurídicos encontraron las fórmulas adecuadas para suplir las carencias y vacíos de esos tratados internacionales y cumplir con la esencia y el espíritu de la Declaración Universal de Derechos Humanos.

El embajador Pérez de Cuéllar tuvo, a lo largo de su exitosa vida, que sortear algunos inesperados sucesos.

Durante el segundo gobierno de Femando Belaunde Terry, Pérez de Cuéllar fue propuesto por el Ejecutivo para desempeñar las funciones de embajador del Perú en el Brasil. La Constitución vigente en aquel entonces establecía que el Senado debía aprobar o no el nombramiento. Contra todo lo supuesto, algunos senadores realizaron una campaña en contra. Un destacado e influyente legislador señaló que Pérez de Cuéllar había participado en dos golpes de Estado, en alusión al papel que, por estar a cargo de la Secretaría General de Relaciones Exteriores, le tocó desempeñar en las juramentaciones de los ministros nombrados inmediatamente después del derrocamiento de dos jefes de Estado, en 1962 y 1968. El primero de los casos se refería a los sucesos del 18 de julio de 1962 cuando las fuerzas armadas depusieron al Presidente Manuel Prado. A Pérez de Cuéllar, aunque no había sido nombrado Secretario General de Relaciones Exteriores, le correspondía en esos momentos, desempeñar esas funciones $\mathrm{y}$, en consecuencia, dar lectura a las resoluciones supremas mediante las que se nombraba a los ministros del nuevo gabinete. Seis años más tarde, en octubre de 1968, con motivo del golpe militar contra el Presidente Fernando Belaunde, Pérez de Cuéllar ejercía nuevamente las funciones de Secretario General de Relaciones Exteriores y tuvo que dar lectura a las respectivas resoluciones supremas del primer gabinete ministerial del régimen del general de división Juan Velasco Alvarado.

Esta práctica se origina en una vieja tradición de la época de la naciente república peruana que adaptó en mucho el protocolo propio de los virreyes del Perú. El funcionario de mayor rango era, en aquel entonces, el Oficial Mayor de Relaciones Exteriores y por tanto era el encargado de hacer dichas lecturas. Aunque las denominaciones de esos cargos se han modificado con el paso del tiempo, hasta hoy se mantiene esa tradición en la persona que detenta el cargo de Viceministro de Relaciones Exteriores. El embajador Javier Pérez de Cuéllar, estaba, en consecuencia, dando cumplimiento a sus funciones como legalmente le correspondía sin que tuviese alguna connotación de carácter político. 
Lo concreto es que el Senado de la República desaprobó a Pérez de Cuéllar, utilizando para ello el peruanismo "balotear" que, incomprensiblemente, hasta hoy no ha sido incorporado en el Diccionario de la Real Academia de la Lengua. Por otra parte, la aprobación de los embajadores por el Legislativo desapareció en la nueva Constitución vigente.

Aunque se ha dicho que esta circunstancia fue la que lo condujo a ser elegido Secretario General de las Naciones Unidas, hay quienes estiman -y yo me encuentro en este grupo- que aún en el supuesto caso de encontrarse en el Brasil como embajador del Perú, habría sido invitado a desempeñar ese altísimo cargo en la ONU.

El otro revés que tuvo Pérez de Cuéllar ocurrió en 1995 cuando diversos grupos políticos lo persuadieron para ser candidato a la presidencia de la República del Perú. En medio de un proceso electoral, desarrollado en un marco convulso por razones de carácter tanto interno como externo, en el cual las circunstancias que se vivían en el Perú en el marco de un conflicto con el Ecuador, las noticias no dejaban espacios para otros candidatos y se centraban diariamente en el accionar del entonces Presidente de la Republica, ingeniero Alberto Fujimori, quien aspiraba a la reelección que concluyó con su victoria.

La renuncia del ingeniero Fujimori a la presidencia de la República antes de concluir su mandato fue el inicio del fin de la profunda crisis que se vivía en el Perú. Establecido un gobierno de transición encabezado por el doctor Valentín Paniagua Corazao, del 25 de noviembre del año 2000 hasta el 27 de julio de 2001, el embajador Pérez de Cuéllar asumió el cargo de Presidente del Consejo de Ministros y Ministro de Relaciones Exteriores del Perú.

Como canciller propició la anulación de la resolución suprema, expedida durante la presidencia de Fujimori, que cesó de sus funciones a 117 funcionarios diplomáticos de carrera. A los pocos días de iniciar sus funciones como canciller, en declaraciones al diario El Peruano, el 5 de diciembre de 2000, señaló lo siguiente: "Esta resolución fue arbitraria, inconsulta y una especie de venganza de las autoridades de ese momento, contra funcionarios ante los cuales no cabía ningún reproche". 
También se inició, durante su gestión, el proceso para dejar sin efecto el retiro del Perú de la Convención Americana sobre Derechos Humanos o Pacto de San José de Costa Rica, iniciado durante la gestión del gobierno presidido por el ingeniero Fujimori.

Al año siguiente, en 2002, asumió el cargo de Embajador del Perú en Francia y ante la Unesco. Ahí, como ya lo hemos señalado, había iniciado su carrera diplomática en el exterior, país donde conoció a Yvette Roberts, ciudadana francesa con quien se casó y tuvo dos hijos: Francisco y Cristina, más conocida esta última con el hipocorístico de Pitusa. Años después contraería nupcias con una peruana, la señora Marcela Temple Seminario, con quien no tuvo descendencia.

Con Javier Pérez de Cuéllar me unió siempre una relación muy especial pues fue el primer jefe que tuve cuando, a los 18 años, ingresé a trabajar, como ayudante quinto, en la Dirección de Personal de la cancillería. En aquellos días la edad mínima para ingresar a la Academia Diplomática era de 21 años. De esta manera, mi ingreso a Torre Tagle me permitía realizar una práctica que, en mi caso particular, fue sumamente beneficiosa.

La primera impresión que tuve de Pérez de Cuéllar fue que estaba ante una persona muy parca, seria y algo misteriosa, atribuciones que algunos atribuían a una parálisis facial que lo había afectado años atrás. Un día me llamó y, sorpresivamente, me pidió que le redactara un informe sobre el caso de un empleado administrativo. Cuando lo terminé, lo leyó de inmediato, le hizo algunas modificaciones y me explicó, denotando vocación por la docencia, por qué las hacía. Luego me dijo: "Tiene usted una excelente redacción, muy lógica y muy clara". Fue así como empezó una relación muy positiva entre él y yo. Pude apreciar su enorme cultura, que parecía no tener límites. Los temas sobre historia, literatura y política nacional e internacional no faltaban. Pude apreciar, además, durante el tiempo que lo tuve como jefe inmediato, sus excelentes condiciones de incansable negociador efectivo, paciente y muy cauteloso. Fui testigo de excepción de cómo obtenía lo que consideraba justo aunque para ello tuviese que enfrentarse a las más altas autoridades del Estado. Así lo hacía y fue fiel a sus principios en todos los actos de su vida. 
Cuando Pérez de Cuéllar inició sus funciones como Secretario General de la ONU, algunos regímenes latinoamericanos estaban seriamente cuestionados en los foros internacionales. La elección de un nacional de América Latina fue tomada con cierta suspicacia por algunos países miembros de la entonces Comisión de Derechos Humanos de la ONU que dieron por cierta la presunción de que el nuevo Secretario General de la ONU se dejaría presionar por los Estados latinoamericanos tenidos por violadores de los derechos humanos. Ello se manifestó de manera muy clara al conocerse la no renovación del director del Centro de Derechos Humanos de la ONU, el doctor Teo Van Boven. En aquellos días, no obstante ser un funcionario muy joven -era primer secretario- había sido nombrado presidente de la Delegación del Perú ante la ya mencionada Comisión de Derechos Humanos y fui testigo de cómo algunos países organizaron "un acto de desagravio" al profesor Van Boven quien sistemáticamente había venido haciendo referencia a violaciones a los derechos humanos en países de África y América Latina. Cuando me tocó intervenir, señalé que tenía la sólida convicción de que Pérez de Cuéllar tenía una profunda vocación de promoción y respeto por los derechos humanos y que la decisión de no renovar al doctor Van Boven no había sido una determinación del nuevo Secretario General sino de su antecesor. Al parecer estas precisiones calmaron los ánimos y las alusiones negativas encaminadas a opacar al embajador Pérez de Cuéllar no volvieron a producirse. Los acontecimientos posteriores demostraron que el doctor Pérez de Cuéllar no era una persona que aceptara presiones y así lo demostró durante los dos períodos en el más importante cargo que existe en el mundo de los organismos internacionales.

Han pasado ya algunos años de estos acontecimientos que, como alguna vez me dijera el propio embajador Pérez de Cuéllar, "no me quitan el sueño" Se mostró siempre sereno, en medio de las grandes tensiones que rodean siempre al tema de los derechos humanos. Su prestigio fue incrementándose día a día y llegó a ser vox populi que era un funcionario cuyos pensamientos eran siempre convincentes sea que se expresara en español, francés o inglés, idiomas que dominaba a la perfección. Una frase que parecía gustarle mucho era: La paz debe ser una victoria sin perdedores. 
Casi al iniciar el presente escrito me referí a la vinculación que Pérez de Cuéllar tuvo con el centro histórico de Lima. Cuando falleció fue velado íntimamente en su residencia donde pasó sus últimos años. Luego, de conformidad con el dispositivo legal que estableció que sería sepultado con honores de Jefe de Estado, sus restos fueron trasladados al Palacio de Torre Tagle. Un importante diario local informó acerca de estos hechos con el título de "La última noche del embajador Pérez de Cuéllar en Torre Tagle." Al día siguiente, antes de ser conducidos al cementerio, en la iglesia de San Pedro se celebró una misa de cuerpo presente con cuatro concelebrantes presididos por el cardenal Pedro Barreto Jimeno y el Nuncio Apostólico, monseñor Nicola Girasoli. Ahí se dio lectura a los mensajes enviados desde Roma por el Papa Francisco y el monseñor Carlos Castillo, arzobispo de Lima.

Siempre fue muy cuidadoso con los detalles. Por ello no me sorprendió que hubiera dispuesto que la lápida del mausoleo en el que iban a reposar sus restos en el cementerio Presbítero Maestro de Lima, reprodujera párrafos de la Declaración Universal de Derechos Humanos, proclamada en 1948 en París por la Asamblea General de las Naciones Unidas en acto que el entonces joven diplomático siguió con atención cuando iniciaba su carrera diplomática.

Al reiterar mi agradecimiento a la Sociedad Peruana de Derecho Internacional por haberme solicitado que redactara estas líneas, debo precisar que, como es notorio, tan solo he rememorado algunos pasajes de una vida centenaria que estuvo siempre al servicio de su país y de la justicia. Este es el Pérez de Cuéllar que yo recuerdo y al que rindo homenaje mediante estas palabras escritas al correr de la pluma.

Lima, marzo de 2020. 

Notas NECROLÓgICAS 



\title{
El Perú y Latinoamérica han perdido a un DIPLOMÁTICO EXCEPCIONAL Y EL MUNDO A UN INTERNACIONALISTA QUE LUCHÓ POR LA PAZ Y LA DIGNIDAD
} GLOBAL

\author{
Javier Felipe Ricardo Pérez de Cú́llar y de la Guerra \\ (19 DE ENERO DE 1920 - 4 DE MARZO DE 2020)
}

\section{Oscar Maúrtua de Romaña*}

Javier Pérez de Cuéllar fue el quinto Secretario General de las Naciones Unidas entre enero de 1982 y diciembre de 1991. Fue abogado, diplomático de carrera y actuó en la política del país. Asimismo, trabajó en el Ministerio de Relaciones Exteriores desde 1940 y en el Servicio Diplomático desde 1944.

Respecto a su vínculo con la Sociedad Peruana de Derecho Internacional (SPDI), el 4 de mayo de 1962 don Javier Pérez de Cuéllar fue designado Miembro Asociado de la Institución, y el 15 de diciembre de 1966 fue promovido a la categoría de Miembro Titular. En la sesión del Consejo Directivo de la Sociedad, de fecha 7 de diciembre de 1989, se acordó por unanimidad designar Miembro Honorario al Embajador Pérez de Cuéllar. Asimismo, durante mi actual gestión como Presidente de la SPDI, se acordó por unanimidad, el 28 de setiembre de 2017, designar a don Javier Pérez de Cuéllar, Miembro del Consejo de Honor de la Institución.

En su relación con la Cancillería, Pérez de Cuéllar participó en misiones en las embajadas del Reino Unido, Bolivia y Brasil, regresó en

Presidente de la Sociedad Peruana de Derecho Internacional - SPDI.

A solicitud de la Columna "Cafe Viena" de Reuters, el presente texto fue reproducido y publicado el pasado 6 de marzo. 
1961 al Ministerio, donde permaneció hasta 1969, excepto dos años en los que fue embajador en Suiza (1964-1966). En 1969 fue nombrado embajador del Perú ante la Unión de Repúblicas Socialistas Soviéticas (1969-1971) por primera vez, en el gobierno de Juan Velasco, rompiendo el marco estrecho de la diplomacia peruana hasta entonces.

En su vínculo con las Naciones Unidas, en 1979 Javier Pérez de Cuéllar fue nombrado subsecretario de la ONU y, en diciembre de 1981, fue elegido Secretario General de la Organización de las Naciones Unidas. Con tal motivo en aquel entonces, el Consejo Directivo de la Sociedad Peruana de Derecho Internacional acordó expresarle sus más efusivas felicitaciones. En la carta que le dirige con tal fin el Presidente de la institución, Embajador Luis Alvarado Garrido, al Embajador Pérez de Cuéllar, con fecha 16 de diciembre de 1981, le expresa: "Nuestra Sociedad ve con singular satisfacción y legítimo orgullo que uno de sus ilustres miembros haya sido escogido, por sus eminentes dotes profesionales $y$ personales, para el más importante cargo internacional, que seguramente desempeñará usted con el acierto y lucimiento de siempre, en aras de la paz y del progreso del mundo".

Tras ser reelegido como Secretario General en 1986, utilizó hábilmente la diplomacia para lograr el "alto al fuego", que puso fin a la Guerra Iranoiraquí. En 1991, negoció el fin de las hostilidades en la guerra del Golfo Pérsico. Logró la liberación de los rehenes occidentales secuestrados por el grupo islámico Hezbolá en Líbano, y la paz entre el gobierno y la guerrilla de El Salvador.

En el plano de la política nacional, a solicitud de distintos grupos políticos peruanos, Javier Pérez de Cuéllar accedió a ser candidato a la presidencia de la República en 1995. Con este fin, en 1994, fundó el partido político Unión por el Perú. En las elecciones alcanzó la segunda mayor votación, pero fue reelegido en primera vuelta el entonces Presidente Alberto Fujimori al obtener el $64 \%$ de votos válidos (la ley electoral peruana otorga el triunfo en primera vuelta al candidato que obtenga más del $50 \%$ de votos válidos).

Asimismo, desde el 25 de noviembre del año 2000 hasta el 27 de julio de 2001, fue Presidente del Consejo de Ministros y Ministro de 
Relaciones Exteriores del Perú durante el gobierno de transición encabezado por Valentín Paniagua Corazao. En el 2002 asumió el cargo de Embajador de Perú en Francia y ante la Unesco.

En el plano académico, Javier Pérez de Cuéllar se desempeñó también como profesor de Derecho Internacional en la Academia Diplomática del Perú y como Profesor de Relaciones Internacionales en la Academia de Guerra Aérea del Perú. Entre sus libros destacan: Manual de Derecho Diplomático (Manual of Diplomatic Law), 1964 y 1998; Orden o Anarquía (1992); Peregrinaje por la paz, editado originalmente en inglés (Pilgrimage for peace) en Nueva York (1997 y 2000); y, Los Andagoya (novela) 2014.

Marzo de 2020 



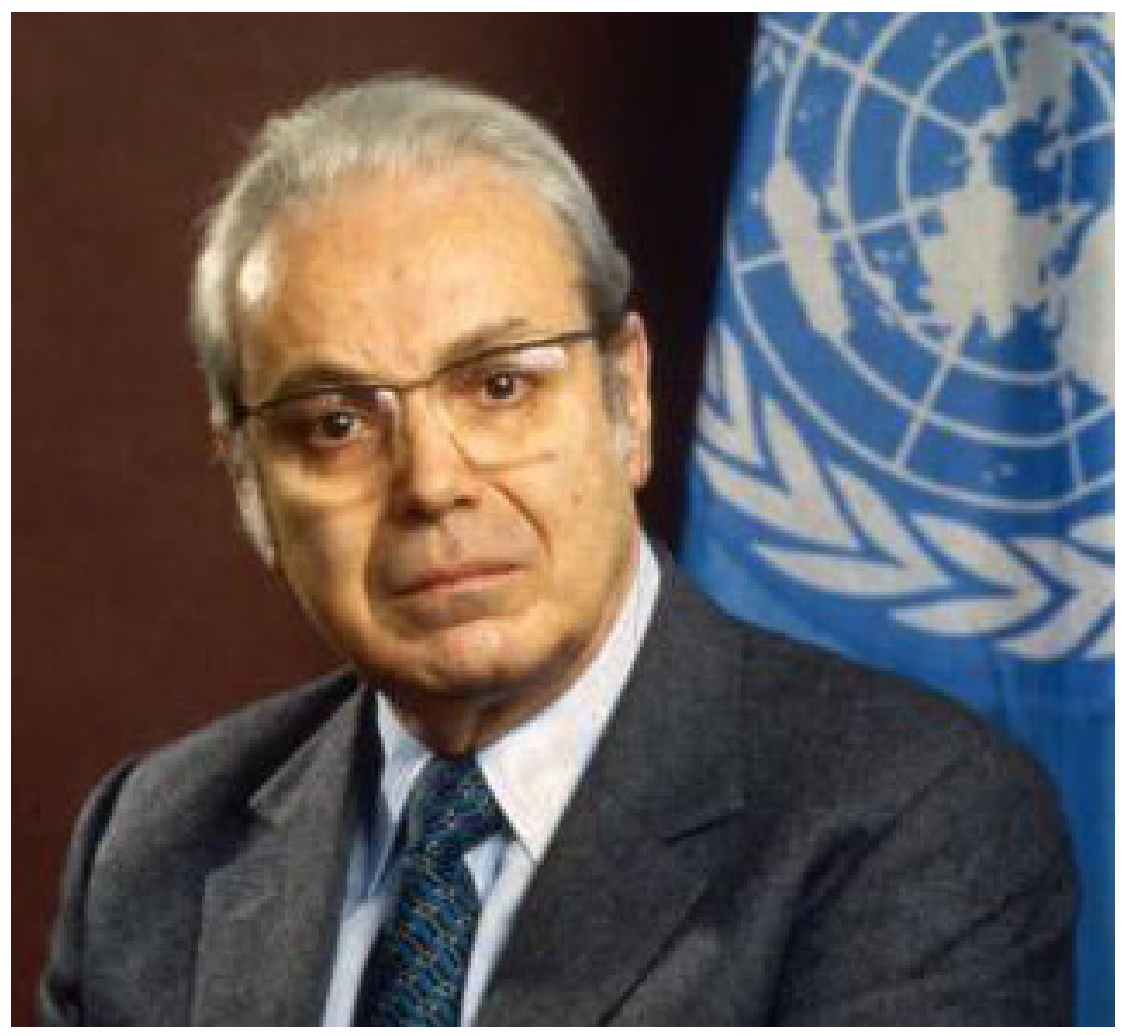

\section{Javier Pérez de Cuéllar}

(Lima, 19/01/1920 - Lima, 04/03/2020) 



\section{Javier Pérez de Cuéllar: \\ Una vida dedicada al Perú y a la diplomacia}

\section{Manuel Rodríguez, Cuadros*}

Javier Pérez de Cuéllar ha fallecido. A los cien años. Como si en el simbolismo del siglo hubiese querido expresar su filiación y fe por un país milenario. El Perú. La patria de sus desvelos, sueños y realizaciones. En lo profesional Pérez de Cuéllar fue un devoto de la patria. Un diplomático al servicio de la Nación. En lo personal, un hombre amante de la literatura. Con una sensibilidad humana aguda. Expresada siempre en la mesura del juicio justo o el pensamiento equilibrado. Un liberal - social de pensamiento y obra. Sus actos oficiales y cotidianos siempre estuvieron signados por el respeto al otro. Aún en la crítica. Tenía la virtud diplomática de tomar una distancia de los hechos. Lo que le permitía el análisis y el juicio objetivo. Esencial para las decisiones políticas. La diplomacia es política entre Estados. Y en esa visión objetivada de la realidad, siempre preservó y cultivó una línea de naturaleza ética. Nunca una decisión contraria al derecho internacional. Jamás alguna otra contraria a la democracia o los derechos humanos.

Javier Pérez de Cuéllar ingresó al Ministerio de Relaciones Exteriores en 1940. En esa época, en el Perú, la dualidad campo-ciudad escondía aún las fracturas de la vida peruana. Y la democracia era una ucronía que sólo podía leerse en constituciones republicanas casi nunca aplicadas.

Diplomático y docente. Miembro Titular y del Consejo de Honor de la Sociedad Peruana de Derecho Internacional.

Artículo publicado en el Diario La República, el 6 de marzo de 2020. Disponible en: https://arepublica.pe/politica/2020/03/06/javier-perez-de-cuellar-una-vida-dedicadaal-peru-y-a-la-diplomacia/ 
En el mundo, la violencia se generalizaba con la segunda guerra mundial. Las conciencias libres aprendían que frente al fascismo y al nacional socialismo, había que oponer las ideas y los valores de la democracia. En ese mundo inició Javier Pérez de Cuéllar su carrera diplomática. Y seguramente esas circunstancias abonaron sus sentimientos a favor de la libertad, la democracia y el respeto al otro.

Veintidós años después, luego de haber servido en Lima, Francia, Inglaterra, Bolivia y Brasil, accedió al grado de Embajador del Servicio Diplomático de la República. Cuatro años más tarde asumió la jefatura del Servicio Diplomático como Secretario General de la Cancillería. En 1979 fue nombrado Secretario General Adjunto de las Naciones Unidas para Asuntos Políticos Especiales. Tres años más tarde, el 15 de diciembre de 1981 fue electo, por unanimidad, Secretario General de las Naciones Unidas. Y reelecto el 19 de octubre de 1986.

La historia posterior está más cerca de nosotros. Su filiación por el Perú y por la democracia lo condujeron a asumir la responsabilidad de representar a la conciencia democrática del país, en las elecciones de 1995, enfrentando a la dictadura. El año 2000, restaurada la democracia, por la acción cohesionada en uno de los escasos momentos de responsabilidad y conciencia democrática en la historia del país, asumió la Cancillería y la Presidencia del Consejo de Ministros en el gobierno constitucional de transición de Valentín Paniagua.

Aludiendo a la memoria, Schopenhauer señalaba que "la verdadera salud del espíritu consistía en la perfección del recuerdo". Recordar a Pérez de Cuéllar es hacer memoria, también, de su gestión como Secretario General de las Naciones Unidas.

En esa salud de espíritu, recordemos que, cuando asumió la Secretaría General, en enero de 1982, el mundo, con asombro y pesar, observaba cómo la lógica del conflicto se agudizaba peligrosamente.

En abril se inició la guerra de Las Malvinas. En junio la cumbre industrializada de Versalles fracasó en su intento de definir una estrategia económica común frente al Este. Casi simultáneamente Israel atacó el Líbano. Irán e Irak seguían escalando en la guerra. En noviembre, Andropov 
rechazó la propuesta americana de "opción cero". Su contrapropuesta para disminuir el 25\% de los misiles intercontinentales corrió la misma suerte por parte de Washington. En marzo del 83, el presidente Reagan lanzó la Iniciativa de Defensa Estratégica. Y asumió una posición crítica sobre las negociaciones SALT II, que Carter había impulsado. La lucha ideológica recrudeció. El diálogo Este-Oeste se fue tornando en sólo un recuerdo. El inmovilismo se afianzaba. La desconfianza reaparecía. En París, "Le Monde" alertaba contra el resurgimiento de la guerra fría.

En el ámbito económico el problema de la deuda estallaba. El Norte y el Sur constataban en Cancún la imposibilidad del diálogo. América Latina iniciaba su costoso recorrido por la década perdida.

Las Naciones Unidas se aprestaban a enfrentar una de las más grandes tensiones de su historia. Desconfianza de los centros de poder mundial. Insatisfacción de las aspiraciones de los países en desarrollo. Carencias presupuestarias cada vez más ostensibles. Élites y grupos de presión que inducían al aislacionismo para vaciar o minimizar su agenda. Los EEUU redujeron su cuota. La crisis se aceleró.

En 1985, Maurice Bertrand en "L'Etat du Monde" sintetizó la situación: "la ONU, en definitiva, aparece sólo como un foro de propaganda... nadie sabe todavía qué tipos de reforma podría dar mayor utilidad a la organización y el escepticismo continúa prevaleciendo sobre la posibilidad misma de esa reforma".

Seis años después, avanzada la gestión de Pérez de Cuéllar en la Secretaría General, el mismo Maurice Betrand constató el éxito de una diplomacia que produjo el cambio. Bajo la sabia fórmula de cambiar sin alterar drásticamente los equilibrios. Una diplomacia al decir de Francois Miterrand, de "force tranquile".

En la edición del L'Etat du Monde de 1989, Bertrand escribió: “desde 1988, la Organización de las Naciones Unidas y su Secretario General, Javier Pérez de Cuéllar, gozan de una sostenida popularidad: el papel jugado por la organización en la resolución de los conflictos regionales ha ganado la primera página de la prensa internacional; las fuerzas para el mantenimiento de la paz de la ONU han obtenido el Premio Nóbel de la Paz”. 


\section{¿CÓMO EXPLICAR ESTE CAMBIO EN LA SITUACIÓN?}

El hilo de la respuesta se encuentra en una de las ideas centrales que Pérez de Cuéllar desarrolló en su Memoria del año 1991. "El renacimiento de la organización ha reflejado un cambio cualitativo, tanto de actitudes como de percepciones. Es, además, resultado de la activa cooperación de los Estados miembros y de largos preparativos y arduos esfuerzos de la Secretaría en circunstancias desalentadoras. Se originó hace algunos años, cuando en la cambiante atmósfera internacional comenzaron a vislumbrarse oportunidades de adoptar medidas de mantenimiento de la paz. Son clarísimas las diferencias entre la situación sobre la que informo hoy y la que di a conocer en mi primera memoria anual".

Efectivamente, las Naciones Unidas pasaron, al ritmo de los cambios mundiales y de la acción responsable, imaginativa, eficiente y versátil del Secretario General, de un estado de erosión de su autoridad institucional y prestigio a la situación en la que ejerció, por primera vez en la historia, de manera legítima, las facultades que le otorgó la Carta de San Francisco.

La seguridad colectiva, como sistema de mantenimiento de la paz, había fracasado en la Sociedad de las Naciones. Desde 1945, las Naciones Unidas reprodujeron esta misma frustración. La estructura de la guerra fría y el bloquismo inhibieron, a través del veto, todas las potencialidades del Consejo. Nunca funcionó conforme a las previsiones de la Carta.

A inicios de los años 90, Pérez de Cuéllar obtuvo que, después de 46 años, el Consejo de Seguridad funcione con legitimidad y eficacia. Lamentablemente, con posterioridad a su gestión, los problemas de disfuncionalidad de las Naciones Unidas han vuelto a emerger. Con mayor gravedad.

Con aguda sensibilidad respecto del curso de los acontecimientos mundiales, Javier Pérez de Cuéllar inició, adelantándose a los hechos, una revisión de la función y de los procedimientos de acción del Consejo de Seguridad. A partir de 1987, propició, en ese sentido, una coordinación especial entre el Secretario General y el Consejo. Asumiendo, con tino y firmeza, plenamente las facultades que le otorgaba la Carta, tanto en el ámbito administrativo como en el político. 
Ejerció con relevantes resultados una de sus convicciones, guardadas en el recato de una proverbial humildad. La de saber que un diplomático por más alto cargo que desempeñe, incluido el de Secretario General de las Naciones Unidas, no ejerce poder por sí mismo, sino por delegación. En la diplomacia, el poder lo tienen los Estados. Y por más alta que sea la jerarquía de un negociador -y el Secretario General de las Naciones Unidas lo es- nunca puede confundirse el poder delegado por los Estados con el poder del Estado.

Por el contrario, la diplomacia de la paz y de la negociación supone diferenciar la "potestas", el poder de los Estados, de la "autoritas" del diplomático o el negociador. Para construir la paz hay que ejercer con decisión, cordura, humildad, creatividad y firmeza la "autoritas" del negociador para inducir un realineamiento de la "potestas" de los Estados, a favor de la paz, la estabilidad, el equilibrio y el beneficio mutuo.

Pérez de Cuéllar logró el cambio delineando nuevos equilibrios en el poder mundial. Obtuvo, en el contexto de una situación de crisis, una relación consensual entre el Consejo de Seguridad y el Secretario General. Y lo hizo en la direccionalidad del cambio, la afirmación de la paz, y la promoción de la democracia y los derechos humanos.

A la obtención de la paz entre Irán e Irak se sumaron, como un efecto dominó, los Convenios de Ginebra que pusieron fin a la intervención soviética en Afganistán; la independencia de Namibia; la paz negociada en Angola, el control de la situación en Centroamérica y la paz entre el gobierno salvadoreño y el frente Farabundo Martí para la Liberación Nacional. Al mismo tiempo, se prosiguió con las negociaciones para lograr soluciones pacíficas en el Sahara Occidental, Kampuchea, Chipre e incluso el Medio Oriente.

Sin embargo, la cuestión de la intervención aliada para cesar la ocupación iraquí en Kuwait puso a prueba todo el emergente mecanismo de seguridad colectiva. La situación no estuvo exenta de problemas. Pérez de Cuéllar fue claro. La acción aliada, señaló, era una ofensiva legal, más no de las Naciones Unidas. La diplomacia de la serenidad, la preservación del derecho internacional y la cautela razonada en el manejo de escenarios y variables de concertación, logró superar los escollos. Restablecida la paz, 
las Naciones Unidas asumieron responsabilidades definidas en la ejecución de los acuerdos de cese del fuego.

Estos cursos de acción otorgaron a la organización mundial nuevas y complejas responsabilidades. Desde acciones para regular la independencia de un país (Namibia) hasta el monitoreo de un referéndum de autodeterminación (Sahara Occidental), pasando por la supervisión de elecciones libres (Nicaragua y Haití), la asistencia humanitaria a la población kurda en Irak, o el mantenimiento del grupo de observadores militares que supervisó el cese del fuego entre India y Pakistán. El propio Secretario General definió este amplio abanico de actividades como "tareas de una complejidad y un alcance nunca antes puestos a prueba".

A Javier Pérez de Cuéllar le ha correspondido la tarea histórica de dar respuesta afirmativa a las dos interrogantes, que siempre se utilizaron para criticar a las Naciones Unidas. ¿Pueden las Naciones Unidas reunir las facultades necesarias para restablecer la paz quebrantada y anular los actos de agresión? ¿Tiene la capacidad y los medios para ejecutar proyectos de paz, complejos y cambiantes? Durante casi cinco décadas la respuesta fue no. La gestión de Pérez de Cuéllar respondió que sí. Ello nos da fundadas esperanzas que el actual proceso de reforma pueda retomar el curso del mantenimiento de la paz eficaz, sustentado en el multilateralismo y el derecho internacional.

Pero la gestión de Pérez de Cuéllar no se constriñó al peregrinaje por la paz, como bien se han titulado sus memorias. Reconoció que las relaciones internacionales no se agotan en la vida de relación entre los Estados. Señaló que la interdependencia compleja de nuestros días presenta nuevos desafíos de cooperación y conflicto. Sostuvo que el medio ambiente, los derechos humanos y la pobreza son de prioritaria atención, en una concepción humana de la paz. Como lo son también aquellas realidades emergentes a las que Pérez de Cuéllar caracterizó en su gestión como expresiones del "disloque y desajuste social": el narcotráfico, el tráfico de armas, la toma de rehenes y el terrorismo.

Un estadista tiene la enorme responsabilidad de obtener o preservar la paz y el bienestar de su pueblo. El Secretario General de las Naciones Unidas tiene como su pueblo a los pueblos del mundo. Pérez de Cuéllar así 
lo comprendió y fue un certero constructor de la paz, un constante promotor de la democracia y el respeto a la dignidad del ser humano.

Al mismo tiempo, trabajó por un mundo más equitativo, aun en las relaciones de poder. Alertó, con razón, sobre los peligros de que la mundialización incremente las asimetrías: "En esta época de profunda transición es menester obrar con extraordinario cuidado para evitar un desequilibrio en la gestión de los asuntos internacionales por parte de las Naciones Unidas. Apenas si puede invocarse el concepto tradicional de equilibrio de poder en una situación en la que las capacidades económicas y tecnológicas y su desigual distribución, se han convertido en factores críticos y a menudo decisivos".

Hace unos años, Mario Vargas Llosa, en un homenaje a Javier Pérez de Cuellar, en la Universidad de Lima, señaló que la apuesta afirmativa por el futuro del Perú se encarna, en cada generación, en peruanos cuya trayectoria profesional, creativa y cívica enorgullecería a cualquier sociedad porque han dejado una marca de excelencia en nuestro tiempo.

Jorge Basadre, a su vez, nos ha recordado que la más alta jerarquía entre los peruanos corresponde a quienes han contribuido a realizar al Perú en su vida y en su obra. Y nos ha indicado, también, que la credencial de esta categoría de hombres y mujeres de la patria, es nada más y nada menos que una trayectoria en la que vida y obra tengan por referente dos límites: nada más que el Perú y nada menos que el Perú.

Javier Pérez de Cuéllar encarnó la vida y la obra que Mario Vargas Llosa y Jorge Basadre asignan a los constructores del Perú como Estado y como nación, como utopía y como realidad. 



\section{Jorge Valdez Carrillo}

\section{Gustavo Meza-Cuadra*}

El pasado 26 de enero recibimos con pesar la noticia del fallecimiento de quien se desempeñaba como embajador del Perú en Chile, Jorge Luis Valdez Carrillo, tras más de cuatro décadas de una brillante trayectoria profesional al servicio de los intereses nacionales.

Quisiera reiterar mis condolencias a la familia del embajador Valdez y referirme a un colega y amigo que, además de haber sido uno de los funcionarios más destacados del servicio diplomático, personificó y ahora proyecta -más que nunca- aquellos valores institucionales que han contribuido a cimentar el prestigio de nuestra Cancillería en la región y el mundo.

Días antes de su lamentable partida, le comuniqué la decisión institucional de otorgarle la condecoración de la Orden al Mérito del Servicio Diplomático del Perú José Gregorio Paz Soldán, en el grado de Gran Cruz, que reconoce su invalorable aporte al Ministerio de Relaciones Exteriores y a los intereses permanentes del Perú. Aún con su salud gravemente quebrantada, el incansable sentido del deber del embajador Valdez se

Ministro de Relaciones Exteriores.

El presente documento es una reproducción del artículo publicado por el autor en el diario El Comercio, con el título "La ética del trabajo". Consultado el lunes 3 de febrero de 2020, pudiéndose apreciar en: https:/elcomercio.pe/opinion/colaboradores/ la-etica-del-trabajo-por-gustavo-meza-cuadra-noticia/?ref=ecr. 
manifestó en una misiva formal para agradecer el reconocimiento, con la humildad que caracteriza a personas cuya labor es guiada por un profundo espíritu de servicio. A lo largo de su carrera, Jorge Valdez recibió también las más altas distinciones del Estado peruano: la Orden El Sol del Perú y la Orden al Mérito por Servicios Distinguidos.

Jorge Valdez fue partícipe y actor fundamental de episodios trascendentales de nuestra historia diplomática, como el proceso que condujo a la firma de los acuerdos de paz entre el Perú y Ecuador (1998), y la negociación del Acta de Ejecución de 1999 y su reglamento con Chile; el fortalecimiento de nuestra integración y el desarrollo fronterizo con estos países deben mucho a su esfuerzo incansable y creatividad.

Entre otros importantes cargos, se desempeñó, con talento y responsabilidad, como embajador del Perú en Sudáfrica; representante ante las Naciones Unidas; y embajador en el reino de Bélgica, Luxemburgo y la Unión Europea. Fue muy destacada su gestión como director ejecutivo de la Fundación Unión Europea-América Latina y el Caribe, en la que fortaleció la asociación estratégica entre ambas regiones.

$\mathrm{Su}$ labor como viceministro y secretario general de Relaciones Exteriores representó la modernización de la gestión y la infraestructura de la cancillería, para beneficio de nuestra institución y del Perú.

En octubre del 2016, Jorge Valdez asumió como embajador en Chile. Sus altas capacidades profesionales e intelectuales y su reconocida calidad personal constituyeron un sustancial aporte para la realización del Primer Encuentro Presidencial y Gabinete Binacional Perú-Chile, así como para que la relación bilateral alcance niveles inéditos. Destaco que el embajador Valdez fue condecorado por el canciller Teodoro Ribera con la máxima distinción del Gobierno de Chile, la Orden Bernardo O’Higgins en el grado de Gran Cruz.

Quisiera añadir, pues considero una dimensión muy valorable de las personas íntegras y correctas, que Jorge Valdez contaba con el profundo afecto de los funcionarios en Santiago, y de todos los que tuvieron la oportunidad de tenerlo como jefe o compañero en sus distintas misiones, incluyéndome. En lo personal, guardo con especial aprecio gratos recuerdos 
de nuestro común interés por las relaciones económicas internacionales, así como su invalorable consejo a lo largo de mi carrera.

La ética del trabajo y el compromiso con los intereses permanentes del Perú que caracterizaron al embajador Valdez honran a Torre Tagle e inspiran a los diplomáticos de todas las edades a renovar nuestro compromiso con el país y sus ciudadanos.

Sus colegas le rendiremos un homenaje esta semana, que coincide con la presencia de nuestros embajadores en las Américas, develando una placa con su nombre en la sala de conferencias del edificio institucional Carlos García Bedoya, que se puso en valor durante su gestión. 



\section{José Agustín De La Puente: El Perú como ilusión}

\section{Francisco Bobadilla Rodríguez*}

José Agustín de la Puente ha fallecido esta tarde a los 97 años. En tiempos como los nuestros que todo se mide en términos de eficacia, la vida de don José Agustín ha sido más bien una vida marcada por la fecundidad: por donde pasó, ha dejado frutos de serenidad, optimismo, unidad, caballerosidad, amor a la patria. Sus investigaciones alrededor de la Independencia y la vida republicana son expresión de su amor al Perú, su gente, su geografía. Habló y escribió más del trigo que de la cizaña. Allí donde veía una espiga de esperanza, celebraba el hecho y la iniciativa. Nunca desalentó ninguna aventura intelectual ni apagó sueños de las nuevas generaciones que acudían a su magisterio.

Admiraba a la Generación del 900. De su magisterio nació mi conocimiento de Víctor Andrés Belaunde y de José de la Riva-Agüero. En una ocasión, a propósito de un conversatorio realizado en la Universidad de Piura en 2014, conmemorando el Centenario del célebre discurso de Belaunde "La Crisis presente" (1914, en San Marcos); don José Agustín dijo que "VAB fue un hombre con criterio amplio, un hombre conciliador. Hay personas que son conciliadoras como Belaunde; otras son de enfrentamiento, de violencia. Belaunde sufría con este estilo humano, pues era un hombre de entendimiento que buscaba los puntos de acuerdo con las personas más distintas e, inclusive, con personas con quienes tuvo polémicas muy duras en su vida". Don José Agustín tenía este mismo talante amable, acogedor, conciliador; fue un hombre de paz.

Su fineza de espíritu irrigó su hacer y su obrar. Sus escritos sobre historia, sus intervenciones en congresos, sus pláticas en tertulias, sus clases 
universitarias, sus breves comentarios en pasillos expresaban ilusión humana y esperanza sobrenatural a la vez. Y así se referían a "el Perú como ilusión, no vaga ilusión; sino ilusión retadora para trabajar por su realización". Su optimismo, me parece, se nutría de la virtud teologal de la esperanza, sabedor de que existe un Señor de la historia, que llena de propósito y sentido a la vida humana. De ahí que insistiera una y otra vez en lo importante que es para un pueblo tener una meta común, un objetivo que oriente su trayectoria.

El Perú es lo que ha sido, lo que es y lo que iremos haciendo de nuestra patria, generación tras generación. ¿A qué nos animaría don José Agustín en este tramo de nuestra andadura? A seguir buscando la unidad en medio de la discordia, a comprender que la tarea pública no es un beneficio ni un regalo, sino una obligación vinculante entre la patria y la persona. Gracias, Don José Agustín por el legado de optimismo primaveral que nos deja. 


\section{Pronunciamiento}





\section{Pronunciamiento respecto a la Ley N $^{\circ} 31012$ "LEY DE PROTECCIÓN POLICIAL"}

El Consejo Directivo de la Sociedad Peruana de Derecho Internacional (SPDI), ante la promulgación congresal de la Ley $\mathrm{N}^{\circ} 31012$ "Ley de protección policial", ha considerado pertinente emitir el siguiente pronunciamiento:

El Perú está siendo reconocido como una nación que está sabiendo manejar con eficiencia la crisis sanitaria de la pandemia y al mismo tiempo estableciendo un programa de recuperación económica nacional con especial interés para la extrema pobreza. En tal contexto, no contribuye a tan positiva imagen que se adopte una ley, que se sabe que era un proyecto presentado en el Parlamento disuelto y que el Ejecutivo no "observó" -expresión de la hermenéutica legislativa según la cual el Presidente de la República no promulga una ley proveniente del Legislativo, sino que deja que los plazos fenezcan- por lo que fue promulgado recientemente por el nuevo Congreso.

Somos conscientes que el personal policial del Perú merece mayor protección jurídica para el mejor cumplimiento de su función, sobre todo para enfrentar las graves amenazas a la sociedad peruana, como el crimen organizado, la inseguridad ciudadana, el terrorismo y el narcotráfico. Creemos que esa es la intención de la citada ley.

Sin embargo, se hace evidente una descoordinación técnica entre la segunda parte del artículo primero y lo dispuesto en el artículo tercero.

En el artículo $3^{\circ}$ se establece que esta ley de protección policial no se aplica en caso se vulnere alguna norma del Derecho Internacional de los Derechos Humanos. Esta rama especializada del derecho internacional, reconoce la regulación mundial comparada y extraordinaria de la legítima defensa y, por ende, su exigencia de razonabilidad de medios y proporcionalidad, es que es lo que desvirtúa el segundo párrafo del artículo 
primero de la citada ley: “... el principio de razonabilidad de medios será interpretado a favor del personal policial interviniente".

Es precisamente el concepto de proporcionalidad y razonabilidad de medios, el que impide una actuación excesiva y arbitraria de parte -para el presente caso- de la policía nacional, lo que hemos visto v.g, hace pocos meses, en nuestros países vecinos a raíz de las protestas sociales.

El principio de proporcionalidad es inmanente al estado de derecho, impone la protección del individuo contra intervenciones estatales innecesarias o excesivas que graven al ciudadano más de lo que es indispensable para la protección de los intereses públicos. La razonabilidad refiere a la condición de aquello que resulta razonable y que, por lo tanto, es acorde a la razón. Lo que busca el principio de razonabilidad es el imperio del sentido común y de la lógica.

Por tanto, consideramos que la referida ley debería ser revisada, de forma que la protección policial que se busca en el artículo $1^{\circ}$, no se contraponga a las normas del derecho internacional de los derechos humanos, relievadas en el artículo $3^{\circ}$ y de esa forma no se vulneren los derechos reconocidos en la Declaración Universal de Derechos Humanos y la Convención Americana de Derechos Humanos, entre otros tratados de los que el Perú es Parte.

Lima, 6 de abril de 2020 


\section{RESEÑAs BibLIOGRÁfiCAS}



Corporación Andina de Fomento. Integridad en las Políticas Públicas: Claves para prevenir la corrupción. Bogotá, 2019.

De manera bastante pertinente, la Corporación Andina de Fomento ha tenido a bien publicar un acucioso reporte sobre el impacto de la corrupción en los gobiernos de América.

$\mathrm{Su}$ objetivo es brindar un análisis sobre el avance en el desarrollo de las políticas públicas anticorrupción y dar luces sobre los principales desafíos que enfrentan actualmente. De esta forma, se han identificado las líneas de acción más importantes emprendidas dentro y fuera de América, los aprendizajes obtenidos y los aportes de la literatura especializada.

El referido informe incluye gráficos comparativos y cuadros con datos regionales que brindan solidez a cada uno de los planteamientos ofrecidos. Podemos encontrar así información sobre la percepción ciudadana y empresarial sobre la corrupción, percepción entre corrupción y confianza, tiempos para realizar trámites, castigos judiciales a la corrupción, leyes de acceso a la información, sectores vulnerables a la corrupción, entre otros.

Una de las primeras conclusiones es la cuantificación que el estudio hace sobre el costo de la corrupción a la sociedad en términos económicos así como de bienestar y afectación al desarrollo. De ahí que se realice una primera correlación entre corrupción y desigualdad socioeconómica, disminución del crecimiento económico, inversión, y pérdida de credibilidad en las instituciones públicas.

De la misma forma, el reporte ofrece una definición de corrupción más amplia que la meramente legal a fin de abarcar las distintas modalidades que la ley no incluye. Vale decir, evita interpretar la corrupción exclusivamente como un tipo penal, para repensarla como un factor más grande de afectación al desarrollo del gobierno y al ejercicio de las políticas públicas.

En consecuencia, esta publicación hace mención a los arreglos institucionales como aquellas fórmulas que pueden reducir las posibilidades del ejercicio de prácticas de corrupción. Son cuatro las categorías en las que han sido agrupadas: reglas y control de la función pública, mecanismos de entrada a la burocracia y a la política, transparencia y monitoreo ciudadano, y la gobernanza de los intereses privados. 
El primer aspecto sobre las las reglas y control de la función pública, propone determinar claramente los criterios para el ejercicio de esta de manera que se eviten subjetividades, por lo que su diseño debe ser muy cuidadoso a fin de evitar más medidas burocráticas. De igual forma, el control de fiscalización debe efectuarse durante todo el funcionamiento de la gestión (antes, durante y después) y se debe el fortalecer el mecanismo de sanción judicial.

Una segunda categoría abordada está relacionada a los mecanismos de entrada a la burocracia y a la política. El reporte plantea como principios la transparencia y la meritocracia y por consiguiente, la permanente comunicación de los logros obtenidos en cada gestión que facilitará la rendicion de cuentas y por ende el aumento de confianza de la ciudadanía. Estas reformas pueden implicar modificar las leyes de conformación de los partidos políticos, determinar nuevas reglas de financiamiento político, fortalecer los tribunales electorales, establecer procesos de reclutamiento a la función pública imparciales y fortalecimiento de la profesionalización del servicio civil.

El tercer punto analizado es la transparencia y el monitoreo ciudadano, que significa contar con información sobre quienes gestionan los recursos del Estado, sensibilizar a la población sobre la identificación de actos de corrupción, y generar canales de denuncia y reclamo. Para esto, resulta fundamental la promoción más amplia de la libertad de prensa y altos niveles de cobertura mediática.

Por último, la gobernanza de los intereses privados es un punto especialmente sensible puesto que significa hacer corresponsable al sector privado en los actos de corrupción. No basta -señala el estudio- con crear y aplicar normas e instrumentos legales, resulta necesario el fortalecimiento de los órganos de fiscalización e investigación y rediseñar los mecanismos de relacionamiento entre Estado y sector privado a fin de promover su integridad. Otro plano no menos importante es la gobernanza de las empresas estatales y sus procesos de toma de decisiones a nivel contractual, elección de funcionarios, obtención de ingresos, etc.

Este reporte termina con una propuesta para la implementación de una reforma bajo tres ejes: sistemas políticos contestatables, coordinación ciudadana y un líder creíble. 
Otra conclusión que queremos resaltar es la puesta en valor de las herramientas digitales y el desarrollo del gobierno electrónico en la reducción de la corrupción en todas las categorías mencionadas.

Particularmente, consideramos que el principal mensaje del informe es el de demostrar que la prevención de la corrupción no se reduce a medidas cortoplacistas o aisladas sino, por el contrario, a la reforma de instituciones y mecanismos tanto del gobierno como del sector privado. Si se desea acceder a una mirada moderna y regional de la problemática, esta publicación representa un diagnóstico actualizado y una propuesta sumamente valiosa.

Luciana Cumpa García Naranjo 

Chanamé Orbe, Raúl. Tratado de Derecho Constitucional. Lima: Instituto Pacífico, 2019, pp. 863.

Conocí al profesor Chanamé como jurado de mi examen de ingreso al Doctorado en Derecho y Ciencia Política, en la Universidad Nacional Mayor de San Marcos, a comienzos del año 2019. En esa ocasión, Chanamé fue estricto, pero también fraterno, dándome la grata bienvenida a la Decana de América.

La emoción de ese resultado se ve renovada con el privilegio de leer y reseñar la primera edición de su Tratado de Derecho Constitucional, una de las obras que, no solo resume el camino y la sapiencia jurídica de uno de los más notables exponentes del derecho constitucional peruano, sino que estoy seguro se convertirá en una lectura de carácter imprescindible para las nuevas generaciones de constitucionalistas y aquellos que, especializados en otras ramas del Derecho, requieran de una obra de consulta en derecho constitucional.

Me gustaría en este espacio resaltar, muy sucintamente, algunos puntos notables de esta contribución tratadística, y que me han llamado gratamente la atención, desde la óptica del derecho internacional. Adoptar este enfoque supone, además, un mayor rigor en torno a la valoración de esta obra, puesto que supone descubrir el valor del Tratado de Derecho Constitucional desde un ángulo que no es el central, pero no por ello menos importante, en el contexto del libro.

Una de las ideas más resaltantes es que el autor destaca que el derecho constitucional tiene relación con otras ramas jurídicas, entre ellas, el derecho internacional. Así lo sostiene Chanamé, respecto al derecho de gentes, al señalar que las constituciones comprenden temas relativos a la "suscripción a los tratados, las formas asociativas entre los países, la sujeción a los organismos supranacionales, la forma del establecimiento de las relaciones diplomáticas" (pp. $79-80)$.

En ese sendero, dos aspectos llaman la atención transversalmente.

En primer lugar, resulta sumamente atrayente el capítulo XII del libro, relativo a la teoría del Estado y poderes constitucionales, puesto que brinda una aproximación balanceada del origen de este concepto, destacando las características de territorialidad, soberanía, constitucionalidad, burocracia 
pública y poder legítimo del Estado moderno, el cual es un sujeto central en el estudio del derecho internacional clásico, y que pervive en el contemporáneo. Asimismo, Chanamé ofrece un desarrollo estricto de los elementos del Estado, también explorados por múltiples autores del derecho internacional, y una síntesis muy interesante de los principales teóricos del Estado. En un siguiente capítulo, examina, además, otro aspecto estatal que desarrollan también internacionalistas de la talla de Charles Rousseau, relativo a las formas de Estados unitarios y compuestos. Todo ello conduce a apreciar la seriedad y profundidad del maestro sanmarquino en el tratamiento de su materia.

En segundo lugar, el autor explora la definición que la doctrina da a los derechos humanos (pp. 272-273), las generaciones de derechos (pp. 338-339), los principios que los sustentan (pp. 273-275) y su interrelación con los derechos fundamentales (pp. 209-211); aspectos esenciales en el estudio del actual derecho internacional de los derechos humanos. Además de examinar derechos en concreto en los capítulos VIII, IX y X. En este punto, una humilde recomendación del discente a este eximio aporte, si es posible alguna, es contar también, en una próxima edición, un capítulo (o apartado) sobre el Perú y los sistemas de protección de derechos humanos, entre ellos, el universal y el interamericano.

En síntesis, me gustaría concluir felicitando al profesor Chanamé por su magnum opus, que es uno de los textos más serios y mejor logrados de derecho constitucional, de manos de un autor peruano y respetado profesor sanmarquino, por lo que, indudablemente, constituye una contribución imprescindible para los estudios de derecho constitucional en nuestro país y a nivel de la región. El autor contribuye con su Tratado, de manera indudable, a la forja de una nueva generación de juristas preocupados en lograr, cada vez más, la promoción y protección de la dignidad del ser humano.

\section{Prof. Pablo César Rosales Zamora*}

Doctorando en Derecho y Ciencia Política por la Universidad Nacional Mayor de San Marcos (UNMSM). Profesor de Derecho Internacional en la Facultad de Derecho de la Universidad de San Martín de Porres (USMP) y de Derecho Internacional Privado en la Facultad de Derecho y Ciencia Política de la Universidad Católica Sedes Sapientiae (UCSS). Asesor en la Oficina de Derecho Internacional Público del Ministerio de Relaciones Exteriores del Perú. 
Novak, Fabián \& Namihas, Sandra. Tiempos de transición. La conformación de un nuevo orden internacional. Instituto de Estudios Internacionales de la Pontificia Universidad Católica del Perú y Konrad Adenauer Stiftung. Lima, 2019.

El libro, en su primera edición, se encuentra estructurado en dos capítulos. El primero se refiere a "los órdenes internacionales (1815 2008)". El segundo aborda el "escenario internacional actual".

En la primera parte se hace un repaso de la conformación y características de los "órdenes" que fueron sucediéndose durante los siglos XIX y XX. En la segunda parte, se analiza la dinámica entre las potencias contemporáneas y cómo su interacción definirá la realidad internacional por venir.

Acertadamente, se abre el libro definiendo el concepto de "orden internacional", el cual es el escenario internacional configurado en un determinado momento histórico, en base a los acuerdos, tácitos o expresos, a los que han arribado los actores centrales, generalmente luego de una crisis mayor (de origen bélico, casi siempre), y que refleja los alcances del poder, tecnológico, militar, económico, demográfico, etc., de las grandes potencias, las cuales moldean el sistema internacional en base a sus necesidades y posibilidades.

Este "orden internacional" estudiado en el libro, se refiere a la dinámica de poder generada entre Estados soberanos, por lo que debe ser distinguido del "orden mundial" y del "orden económico internacional", los que implican: el estudio de actores estatales y no estatales, de una parte, y el de los agentes y normativa financiera económica internacional, de la otra.

Si bien es notorio un énfasis en lo económico, en el análisis del escenario internacional actual, ello obedece a los naturales cambios operados en la sociedad internacional desde el fin de la Segunda Guerra Mundial en adelante, es decir al declive lento pero progresivo de las hegemonías basadas en lo estrictamente militar. La importancia creciente del soft power y de la carrera por descollar en ciencia y tecnología son ejemplos de ello.

El escenario internacional actual estudiado es considerado por los autores como un "orden de transición", de ahí el nombre del libro, que 
probablemente desemboque en un nuevo sistema bipolar, bastante distinto del que en el siglo XX tuvo como protagonistas a EE.UU. y la URSS.

Para llegar a avizorar este posible escenario futuro, los autores analizan las posibilidades de los Estados con vocación y/o posibilidades de convertirse en "potencias hegemónicas", es decir países que podrían ser percibidos no solo como potencias capaces de imponerse en virtud de su poder militar y/o económico, sino además como líderes preocupados por proteger el interés general y generar con ello admiración y adhesiones. También, en esa línea, se pone sobre el tapete el rol de las potencias regionales.

Se estudia el declive de EE.UU. y de Europa, y las posibilidades que tienen de revertir tal aparente decadencia. Asimismo, se hace un análisis de las posibilidades de China y su (casi inexorable) ascenso, así como de los factores que le permitirían o impedirían ser la gran potencia del futuro.

Otros temas tratados en la obra son: la alianza entre China y Rusia, la India y su problemática para llegar a ser potencia mundial, los casos de Irán, Turquía, Brasil (la potencia verde), Sudáfrica, Alemania, Indonesia, Arabia Saudita, Japón, para finalmente considerar el papel de América Latina y el Perú en el escenario internacional.

Luego de la lectura de la obra, cabe reflexionar si alguno de los hipotéticos escenarios futuros presentados nos conducirá a un mundo más seguro o si, por el contrario, se avecina, a mediano plazo, una crisis en el sistema.

Enlopersonalencuentro de lamayor importanciaestudiar y comprender cómo funciona la sociedad internacional. Entender sus particularidades, sus claves y evolución permite acercarse con herramientas adecuadas al estudio del derecho internacional y las relaciones internacionales, tanto desde el punto de vista teórico como práctico. Este libro es un valioso aporte en ese sentido.

Silvio Mezarina García Profesor de Derecho Internacional en la UNMSM smezarinag@unmsm.edu.pe 
Koechlin Febres, Eric Conrad. Guía del proceso emancipador 1780-1866. Colección Bicentenario de la Independencia 1821-2021. Lima: Fondo Editorial del Congreso del Perú. 2019.

Ad portas de conmemorar el Bicentenario de la Proclamación de la Independencia del Perú, como efemérides central de lo que constituye un largo proceso histórico que va más allá de 1821, se han publicado un sinnúmero de estudios y títulos que constituyen una útil herramienta de divulgación histórica cuya finalidad es estimular la participación de la generalidad y así comprender y repensar el significado de este acontecimiento que marcará sin dudas el calendario de la leyenda en los venideros años.

En tal sentido, el Fondo Editorial del Congreso de la República del Perú ha sumado, a su Colección Bicentenario de la Independencia, una nueva publicación intitulada Guía del proceso emancipador 1780-1866 del economista y etnomusicólogo Eric Conrad Koechlin Febres. A través de dicha publicación, de formato grande $(24.5 \times 31.3 \mathrm{~cm})$, con 240 páginas, e ilustraciones (a modo de un coffee book), el autor presenta un interesante recorrido temporal entre los vericuetos y vaivenes de nuestra historia política, social y cultural acaecidos entre 1780 y 1866 . Por ello divide la obra en siete capítulos que explican de forma clara y llana el proceso que desencadenó, paulatinamente, en la emancipación política de la futura República del Perú. Cabe destacar, por añadidura, el tercer capítulo por el novedoso aporte que presenta, desde un enfoque amplio que se circunscribe a la Historia Cultural, en virtud al análisis que pone a la palestra las dinámicas que desarrollaron las clases populares en la conformación de las milicias voluntarias, la intervención de la población afroperuana, el desempeño de la iglesia como agente catalizador y sobre todo la participación activa de la mujer que va más allá de los nombres usualmente estudiados, además, destaca la producción artística-cultural a través de la poesía, la pintura, la gastronomía y la música con la composición, por citar un ejemplo, "La Chicha" "canción festiva y patriótica escrita antes que el Himno Nacional" como refiere el autor.

Por consiguiente establecer o diseñar una guía histórica para este periodo trascendental de nuestro devenir no resulta tarea sencilla puesto que se adoptan criterios subjetivos, los cuales se organizan en función a las fuentes que deben pasar por un riguroso proceso de escrutinio, asimismo, 
se deben superar otros complicados aspectos técnicos como el precisar las referencias geográficas, datos biográficos, producción intelectual destacada, desempeño de instituciones, entre otros escollos que es posible ver superados en este libro.

En suma, parafraseando al maestro Raúl Porras Barrenechea, obtener de los hechos una síntesis vital del pasado en la que palpitan problemas del presente e intenciones del porvenir no es nada fácil, pero esta Guía del proceso emancipador 1780-1866 de Eric Koechlin nos acerca a ello que, al fin y acabo, resulta ser la esencia pura de nuestra historia nacional.

Ricardo Pinto-Bazurco Mendoza* Historiador

Instituto Raúl Porras Barrenechea. Centro de Altos Estudios y de Investigaciones Peruanas de la Universidad Nacional Mayor de San Marcos.

Miembro de la Comisión de Historia de la Benemérita Sociedad Fundadores de la Independencia, Vencedores el 2 de mayo de 1866 y Defensores Calificados de la Patria. 


\section{ApUNTES InStitucionales \\ Y \\ Calendario de suCESOS INTERnacionales}





\section{APUNTES INSTITUCIONALES (Período enero-abril 2020)}

La sección de Apuntes Institucionales, puede ser consultada en nuestro Blog Institucional: https://sociedadperuanadederechointernacional. blogspot.com/

Andrés Rodríguez Delgado

$* * *$

\section{CALENDARIO DE SUCESOS INTERNACIONALES (Período enero-abril 2020)}

La sección de Calendario de Sucesos Internacionales, puede ser consultada en nuestro Blog Institucional: https:// sociedadperuanadederechointernacional.blogspot.com/

Jessica Castro Vargas

$$
* * *
$$


SE TERMINÓ DE IMPRIMIR EN LOS TALLERES GRÁFICOS DE

Tarea Asociación Gráfica Educativa

Pasaje María Auxiliadora 156 - BreÑa

CORREO E.: tareagrafica@tareagrafica.com

PÁGINA WEB: www.tareagrafica.com

TELÉF. 332-3229 / 424-8104 / 424-3411

ABril 2020 LIMA - PerÚ 